\title{
Geochemistry of Rocks and
}

Related Soils and Vegetation

in the Yellow Cat Area

Grand County, Utah

GEOLOGICAL SURVEY BULLETIN 1176

Prepared on behalf of the

U.S. Atomic Energy Commission

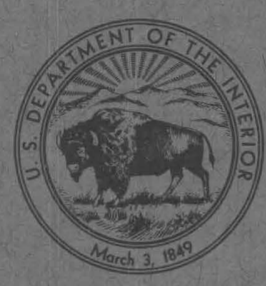




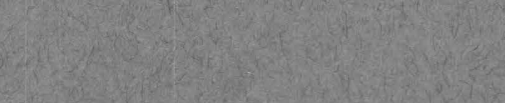

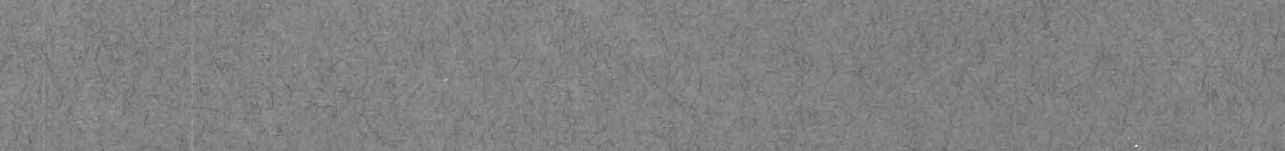
(3.

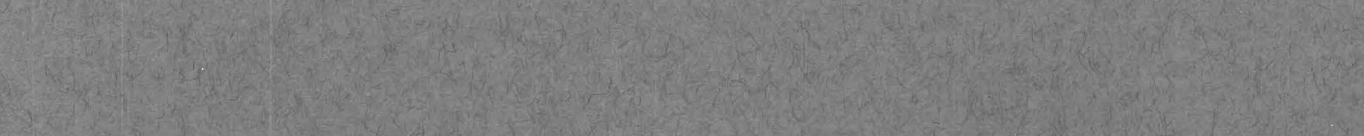

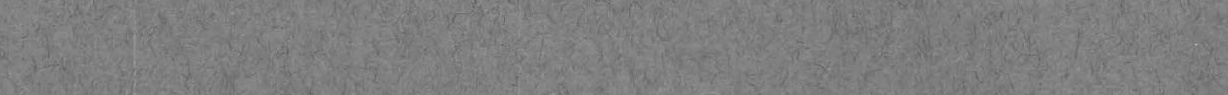

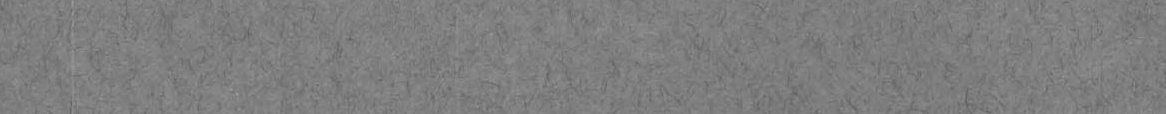

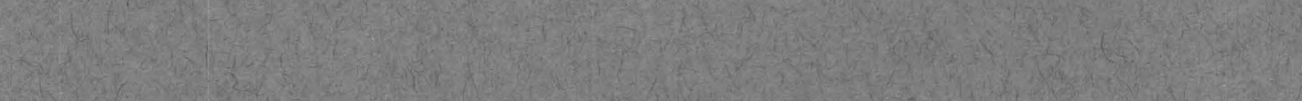

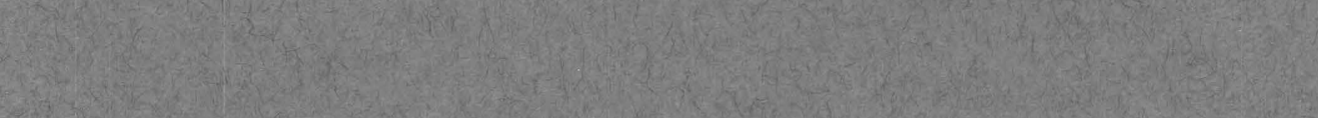

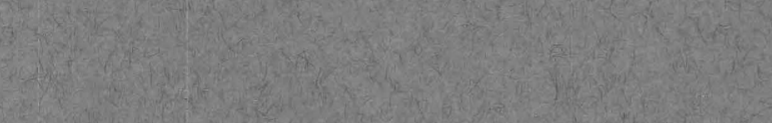

2.

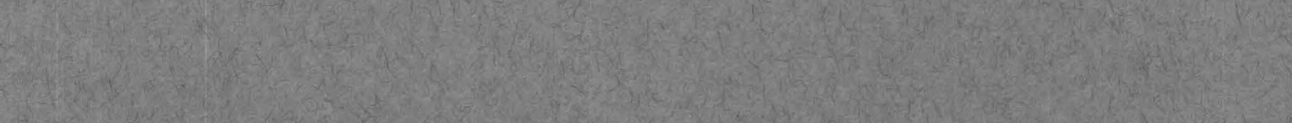
W. 2.7.

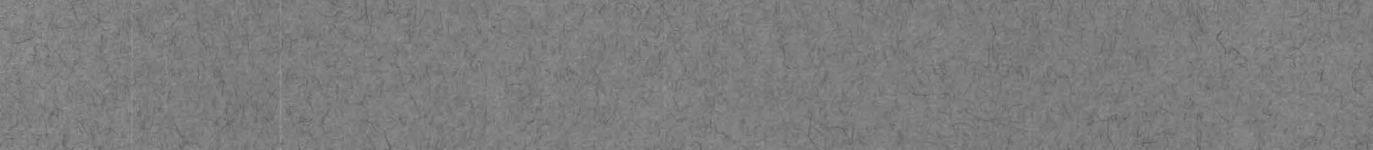
1. 1.5. 3. 1.5.

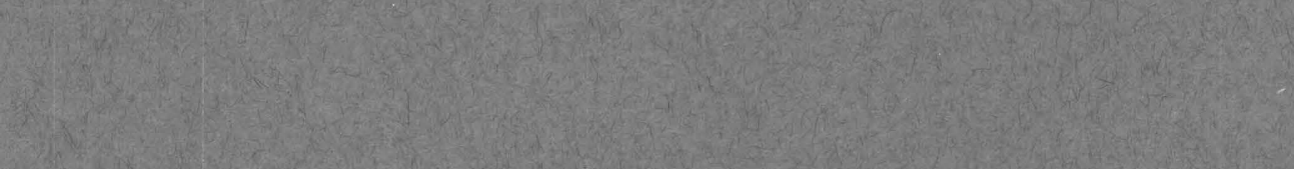

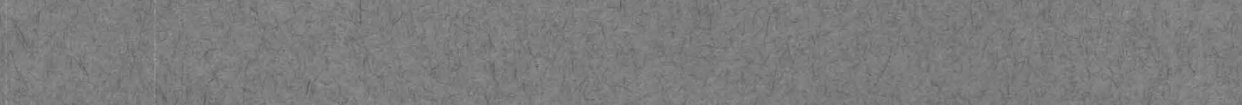

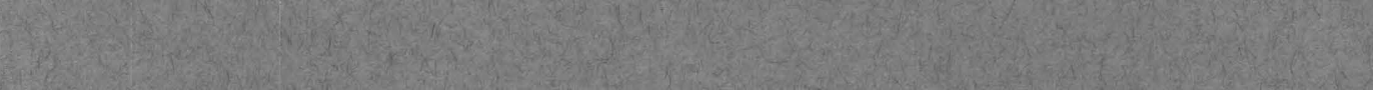
1.4. (3)

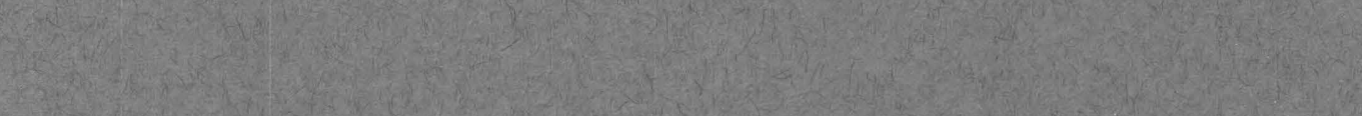
V.

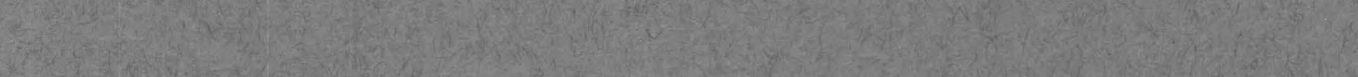

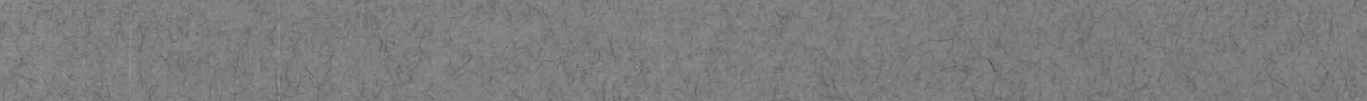

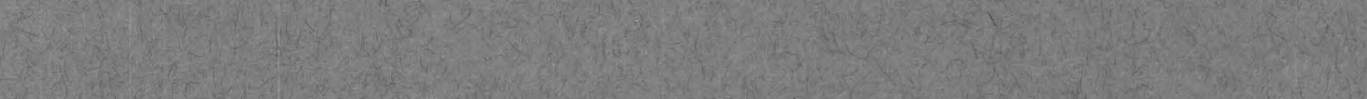
(3)

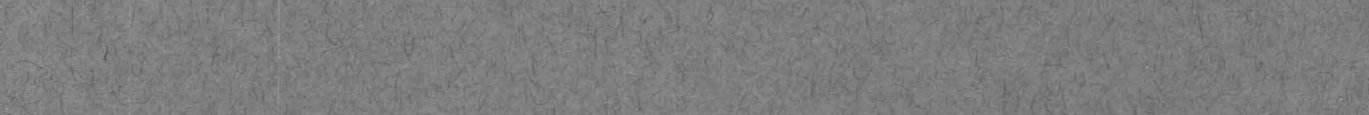

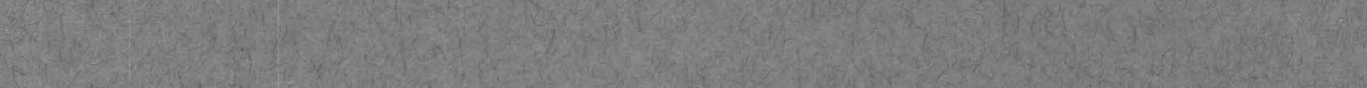

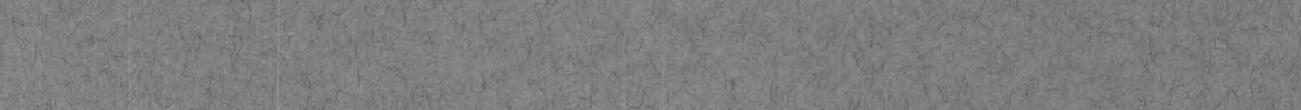




\section{Geochemistry of Rocks and}

Related Soils and Vegetation

in the Yellow Cat Area

\section{Grand County, Utah}

By HELEN L. CANNON

GE O L G I A L S U R V E Y B U L L E T I N 1176

Prepared on behalf of the

U.S. Atomic Energy Commission 


\section{UNITED STATES DEPARTMENT OF THE INTERIOR}

STEWART L. UDALL, Secretary

\section{GEOLOGIGAL SURVEY}

Thomas B. Nolan, Director

The U.S. Geological Survey Library catalog card for this publication appears after index. 


\section{CONTENTS}

Page

Abstract.....

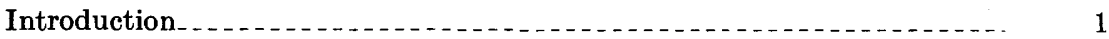

Geography

Location and early history

Topography and climate

Recent climatic history

Fauna and flora

Ground-water conditions . .

Geology

Geologic setting

Stratigraphy $\ldots$

Ore deposits

Geochemistry

Collection and analysis of rock and soil samples. 15

Salt Wash Member of the Morrison Formation

Sandstones surrounding ore deposits_._._.

Sandstones of the ore deposits

Concentration and abundance of elements . .

Statistical analysis

Stratigraphic variations in metal content of the sandstones. . . $\quad 30$

Distribution of metals in the mudstones.

Source of the metallic elements

Present-day weathering of ore minerals as related to prospecting _-_._. $\quad 36$

Geochemical prospecting in the Yellow Cat area..... 38

Prospecting by water analysis...... 38

Prospecting by soil analysis

Botanical prospecting in the Yellow Cat area

Effect of shallow oxidized ore on vegetation

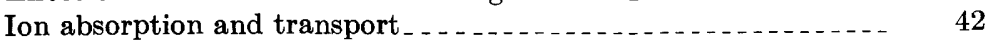

Effect of mineral excesses on growth habits and composition of the vegetation

Uranium and daughter products

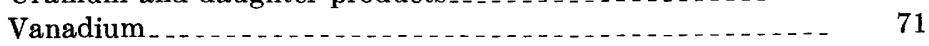

Molybdenum

Selenium

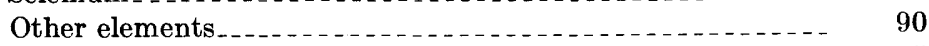

Combined effect of element excesses on plant distribution

Field mapping and sample collection in trial prospecting program

Mapping of indicator plants _....... 96

Collection of plants for uranium analyses._._. 98

Physical exploration in the Yellow Cat area

Drilling by private industry

Geological Survey drilling program _... 99 
Geochemical prospecting in the Yellow Cat Area-Continued

Evaluation of botanical methods of prospecting . . . .

Indicator-plant method................................ 100

Comparative effectiveness of indicator species._.

Association of indicator plants with geologically favorable

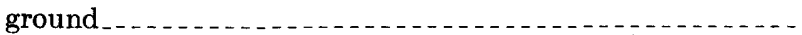

Association of indicator plants with mineralized ground and with ore

The depth factor

102

104

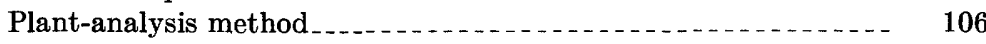

Further limitations of botanical prospecting methods_._._._._. 108

Summary

109

Selected bibliography ........ 111

Index

\section{ILLUSTRATIONS}

[Plates are in pocket]

Plate 1. Map of Yellow Cat Mesa showing uranium content of shadscale (Atriplex confertifolia), Yellow Cat area, Grand County, Utah.

2. Botanical relationships in the McCoy group, Yellow Cat area, Grand County, Utah.

3. Location of drill holes, geologically favorable ground, and indicator plants in the Yellow Cat area, Grand County, Utah.

Figure 1. Map showing location of Yellow Cat area, Thompson district, Grand County, Utah.............................

Page

2 , 3. Distribution of metals from ore to ground surface in openpit Parko 23-2 mine

18,19

4. Selenium-uranium ratios in samples from Thompson district and from Uravan mineral belt

5. Abundance of 5 uranophile elements in 40 samples grouped according to key bed within the Salt Wash Member...

6. Abundance of 7 vanadophile elements in 40 samples grouped according to key bed within the Salt Wash Member

7. Graph showing ratio of uranium uptake to vanadium uptake by plants growing in different chemical environments

8. Townsendia incana, a selenium concentrator in the Yellow Cat area. . . . . . . . . . . . . . . . . . . . .

9, 10. Selenium indicator plants used successfully in uranium prospecting in Yellow Cat area:

9. Astragalus pattersoni

10. Astragalus preussi

11. Astragalus thompsonae, selenium indicator useful in uranium prospecting but difficult to see in field sampling-

12. Allium acuminatum, sulfur concentrator useful in prospecting for shallow uranium deposits in Yellow Cat area. -

13. Bar diagram of indicator-plant distribution compared to

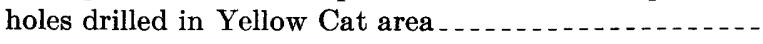




\section{TABLES}

TABLE 1. Flora of the Yellow Cat area, Grand County, Utah........

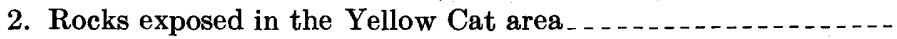

3. Chemical composition of unmineralized sandstones collected near ore in the Yellow Cat area and Uravan mineral belt compared with that of average sandstones..............

4. Metal content in sedimentary rocks and soil above ore body in

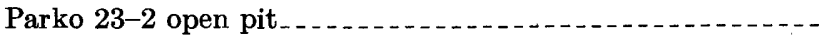

5. Trace elements in sandstones of the Yellow Cat area.......

6. Mean composition of ores collected in Yellow Cat area compared with that of mill pulp (average) from Colorado Plateau .

7. Uranium, vanadium, selenium, and carbonate contents of outcrop samples compared with contents of core samples

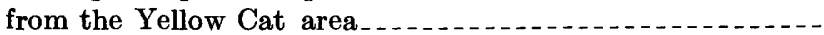

8. Metal content of sandstones in drill cores from the Uravan mineral belt.

9. Relative abundance ratios of elements in three collections of Colorado Plateau uranium ores from the Morrison Formation

10. Average uranium, vanadium, and selenium contents of 11 ore bodies and surrounding rocks compared with contents in sandstone of the Salt Wash Member

11. Abundance of trace metals in key beds of the Salt Wash Member in the Yellow Cat area......

12. Trace elements in mudstones of the Yellow Cat area.......

13. Distribution of metals in mudstones throughout the Morrison Formation

14. Analyses of mineralized waters from Yellow Cat area

15. Toxic elements in spring water and in the ash of associated

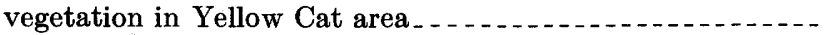

16. Metal content of plants and associated soils collected in the

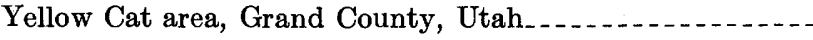

17. Comparison of four metals in the ash of plants from mineralized and unmineralized areas .

18. Ratio of metals in near-surface roots to metals in aerial parts of the plant

19. Tolerance of common plants to uranium ores in Yellow Cat area.

20. Uranium accumulator plants of the Yellow Cat area. roots of deep-rooted woody plants

22. Radioactivity measured in four species of plants in the Yellow Cat area.

23. Vanadium accumulator plants of the Yellow Cat area and their average vanadium content

24. Molybdenum accumulator plants of the Yellow Cat area

25. Tolerance of plants grown experimentally for 3-4 years in seleniferous soils .

26. Selenium content in the ash of various parts of several species of plants 
Page

TABLE 27. Selenium content of primary and secondary accumulator plants in Yellow Cat area compared with maximum contents found in some species by other workers.

28. Average copper and nickel contents in the ash of the aboveground parts of plants in the Yellow Cat area

29. Copper, nickel, and rhenium in the ash of a few plants from Yellow Cat area

30. Trace elements in the ash of Astragalus preussi compared with those in the ash of average legumes

31. Calcium and phosphorus in the ash of a few plants in the Yellow Cat area

32. Indicator plants and the chemical components that may influence their distribution

33. Effectiveness of various plant species as indicators of uranium

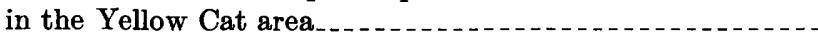

34. Association of indicator plants with geologic favorability for

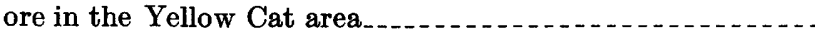

35. Association of indicator plants with mineralized ground in the Yellow Cat area

36. Comparison of indicator-plant distribution with drilling results at various depths.

37. Uranium content of vegetation sampled in the Yellow Cat area as a guide to exploration 


\title{
GEOCHEMISTRY OF ROCKS AND RELATED SOILS AND VEGETATION IN THE YELLOW GAT AREA, GRAND COUNTY, UTAH
}

\author{
By Helen L. Cannon
}

\begin{abstract}
Sulfur, selenium, arsenic, and molybdenum are concentrated along with uranium and vanadium in the ores of the Yellow Cat area, and a geochemical halo of these six elements envelops each ore body. Two botanical methods of prospecting for these geochemical anomalies were developed and tested, and both were successfully used to locate ore. One of these methods involved the collection and analysis of juniper needles and leaves of shrubs. From these analyses, the content of uranium in barren ground was found to be about 0.5 parts per million, and that in mineralized ground about 2 parts per million. The other method involved mapping the distribution of six indicator plants. Two selenium accumulaters, Astragalus patterson and $A$. preussi, proved to be especially good indicators of mineralized ground.

After the plant studies were made, 1,268 holes drilled for the U.S. Geological Survey in the area of plant mapping verified the presence of ore. The selenium indicator plants grow on 81 percent of the ground mineralized at a depth of less than 32 feet and on 42 percent of that mineralized at a depth of from 32 to 170 feet.
\end{abstract}

\section{INTRODUCTION}

Studies of the geochemistry of oxidized uranium deposits and the occurrence of ore metals in surface soils and vegetation have resulted in the development of new methods of geochemical and botanical prospecting in the Yellow Cat area of the old Thompson uranium district in Grand County, Utah. These investigations have led to an evaluation of indicator plants as a prospecting tool by a comparison between results of the botanical studies and the geologic results of a subsequent physical exploration program.

Ore deposits are altered in the zone of weathering, and the products of both chemical and mechanical processes accumulate above the ore or in dispersion patterns as characteristic concentrations whose recognition may be useful in prospecting. Secondary accumulations, either of the element sought or of a "pathfinder" element (Warren, Delavault, and Irish, 1952, p. 131), may occur in the surface soils and waters of the area or may affect either directly or indirectly the vegetative cover. 
The salts formed during weathering in a mineralized area may produce physiological or morphological changes in the plants or may disturb the normal plant distribution patterns. These changes are observed in the field. Metallic ions may also be absorbed by the plants in above-average quantities that can be detected by various methods of chemical analysis. Prospecting by soil analysis was first used on a broad scale by the Russians in the 1930's, and plant analysis was investigated in Sweden at about the same time. The early work in geochemical propecting was ably reviewed by Sergeev (1941), Hawkes (1950, 1957), and Ginzberg (1957).

Prior to the present study, the U.S. Department of Agriculture (Robinson, 1933; Byers, 1935) and the University of Wyoming (Beath and others, 1934) found that a group of plants which poisoned livestock needed selenium in the soil to survive. The toxic areas of the West were carefully studied, and hundreds of plants were analyzed for this element. Agriculturists (Moxon, Olson, and Searight, 1939) divided the plants associated with seleniferous soils into three groups-(1) accumulator plants that can grow on any soil but that absorb large amounts of selenium when rooted in seleniferous soils, (2) indicator plants that grow only in soils at a particular selenium content, (3) and convertor plants not only capable of extracting selenium from insoluble seleniferous compounds but also of returning the selenium to the surface soil in an available form. After a stand of convertor plants is established in a given area, the entire forage crop becomes highly toxic (Trelease and Beath, 1949, p. 105).

Foodstuffs and forage grown on any part of the Morrison Formation in Wyoming were found to be toxic (Knight and Beath, 1937) although the selenium content of the vegetation is fairly low. An area along the outcrop of the Morrison 10 miles southeast of Thompson, Utah, that had long been known to be toxic to sheep was studied by Beath in 1943. He found that selenium indicator plants growing on the Salt Wash Sandstone Member of the Morrison Formation were the cause of the toxicity and suggested a possible relation between the distribution of plants and the uranium-vanadium deposits. $\mathrm{He}$ reported that the content of selenium in the beds corresponds closely to that of vanadium and suggested, therefore, that the two elements might have a common genesis. Molybdenum was also found in amounts believed to be nearly toxic. Beath suggested that the extreme toxicity of these plants might be due to the additive effect of selenium and molybdenum accumulated by the plants.

The author made a preliminary study in 1947 of the plant relations in the vicinity of carnotite deposits in the Colorado Plateau to determine whether the association of selenium indicator plants with uranium ore bodies, as described by Beath, was significant. Results of 
this survey showed that selenium indicator plants are abundant in the Thompson district and that they appear to be restricted to mineralized parts of the Salt Wash Member of the Morrison Formation. A few of the plants collected contained more uranium than had previously been reported in the literature concerning this area.

The Yellow Cat area, therefore, was chosen as the site for an investigation of the selenium-vanadium relationship and its possible use in prospecting for vanadium-uranium deposits. The U.S. Geological Survey began this project in 1949 on behalf of the Division of Raw Materials of the U.S. Atomic Energy Commission, and geochemical studies were continued in the Yellow Cat area through 1951.

Most of the fieldwork was completed during the 1949 and 1950 field seasons. A geochemical study of 10 ore bodies and the enclosing sandstones and shales was made to determine what elements were closely associated with uranium in the ore bodies and whether a geochemical halo that would enlarge the target for prospecting by plant analysis existed around the ore body. The absorption and translocation of uranium, vanadium, molybdenum, and selenium by various plant species were studied as well as the effective depth from which roots of these species could be expected to absorb the metals. Lists were made of all plants rooted in mineralized and barren ground, and from these lists possible indicator plants for uranium deposits were selected. Much of this information was subsequently published (Cannon, 1952). The plant distribution was mapped and analyses were made of plants and of alluvium near known mineral deposits on Yellow Cat Mesa and in the McCoy group of claims. These maps and analyses indicate the variation in uranium content of these materials over mineralized rock and over barren rock.

Finally, the distribution of six indicator species was mapped throughout the Yellow Cat" area. Areas favorable for prospecting, as determined from the distribution of indicator plants and the uranium content of plant tissue, were outlined on geologic maps and filed with the Atomic Energy Commission. Subsequently, from 1951 to 1954 , private companies under contract to the Geological Survey drilled more than 1,250 holes in the area of plant mapping to find new ore bodies and to appraise the reserves of the Yellow Cat area. Additional botanical information was accumulated while drilling was in progress, and plant material has been collected for specific purposes since that time.

Analyses show that uranium, vanadium, and selenium in the ores correlate closely and that very little separation of the elements takes place during weathering. Variations in the distribution of selenium indicator plants and in the uranium content of juniper proved to be the most effective indicators of mineralized ground. Two species of 
Astragalus (A. preussi and A. pattersoni) are most closely associated with mineralized rock of ore grade. Branch tips of junipers contain more than $1 \mathrm{ppm}$ (parts per million) uranium in the ash when the trees are rooted in mineralized ground and less than $1 \mathrm{ppm}$ when the trees are rooted in barren ground. Results of the drilling showed that the ore bodies occur at fairly shallow depths and correlate well with botanically favorable areas.

During the summer of 1949, Mary E. Durrell served as botanical assistant, and during the fall she conducted experiments with Astragalus in a laboratory at Fort Collins, Colo. During the field season of 1950 , the staff included two geological assistants, Louis C. Rove, Jr., and John W. Harbaugh, and a botanist, Richard M. Stillman. Rove was again assigned to the Yellow Cat project during the early part of the Geological Survey drilling program. Two Geological Survey chemists, Ruth Kreher and Faye H. Neuerburg, acted as assistants for short periods of time and conducted field tests for various elements. Additional samples were collected in 1956 by Willard W. Janes and James C. Prentice. I also wish to acknowledge the research on methods of analysis done by Frank Grimaldi, Fred N. Ward, and Claude C. Huffman, and the cooperation of Lewis Rader, Claude Huffman, and the laboratory staff in analyzing more than 500 plant and rock samples that made this report possible. Gwen W. Luttrell assisted in a statistical analysis of the analytical data. Acknowledgment is also made to C. F. Withington and Coy M. Mobley, who directed much of the drilling related to the plant study, and to R. P. Fischer and L. C. Craig for their helpful discussion and constructive criticism.

\section{GEOGRAPHY}

\section{LOCATION AND EARLY HISTORY}

The Yellow Cat area of the Thompson district lies in T. 22 S., R. 22 E. (Salt Lake principal meridian), about 15 miles southeast of Thompson and an equal distance southwest of Cisco, Grand County, Utah. Thompson and Cisco are both small towns on the Denver and Rio Grande Railroad. A gravel access road leaves U.S. Highway 50 four miles east of Thompson, winds through the district, and returns to the paved highway 9 miles west of Cisco. The location of the area is shown in figure 1. Many roads have been constructed in the Yellow Cat area since 1951 as a result of assessment work on new claims and because of the Geological Survey drilling program.

The Thompson district was one of the first uranium-vanadium districts of the Colorado Plateau - the ores were originally mined for radium, and it is claimed that shipments were made to Madame Curie in the early stages of her radium research. According to Huleatt, 


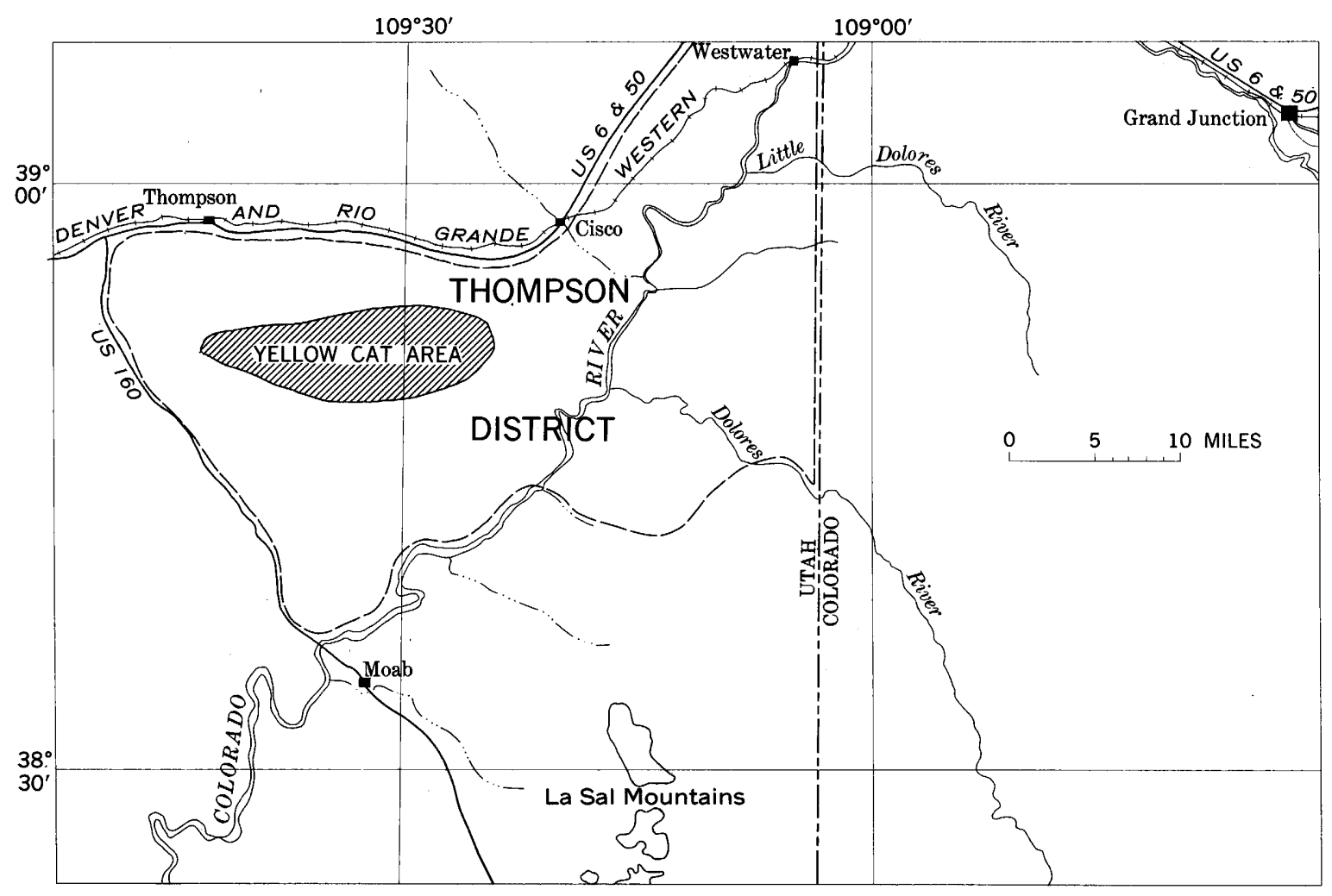

0
0
0
0
0
0
0

FJGURE 1.-Map showing location of Yellow Cat area, Thompson district, Grand County, Utah. 
Hazen, and Traver (1946), the deposits were discovered in 1899 and were worked for uranium and radium from 1911 until 1923 when the pitchblende ores of the Belgian Congo became the source of supply. Mining virtually ceased until 1939 when the ores became valuable for their vanadium content. The U.S. Geological Survey began a study in the Thompson district in 1942 as a part of the Strategic Minerals Program to make an estimate of potential vanadium reserves. A Geological Survey-Bureau of Mines drilling project was carried out in 1943 on the McCoy and Flattop groups of claims. Sixteen thousand tons of ore were mined between 1939 and 1944 when the stockpiling program was discontinued. The area again was deserted until 1948 when mining on the Colorado Plateau was reopened by the Atomic Energy Commission. The ores since that time have been mined for uranium, and vanadium has been a byproduct. At the time of my first visit to the area in 1947, the only inhabitants in the entire area were living in a cabin at the old Yellow Cat Campsite, one of the few places where water is available. In 1954, at the height of the mining activity that resulted from the Survey drilling program, the population may have been as much as 50 .

\section{TOPOGRAPHY AND CLIMATE}

The Thompson district includes about 200 square miles of desert in the Canyon Lands physiographic subdivision of the Colorado Plateau (Hunt, 1956). The Yellow Cat area, in the center of the district, is about 4 miles long and $1 \frac{1}{2}$ miles wide. It is characterized topographically by low relief; a series of sandstone cuestas and dip slopes separated by intercuestal lowlands are the principal landforms. The altitude of the area ranges from 4,800 to 5,100 feet. The climate is semiarid; the summers are hot and dry and the winters are cold. The average annual rainfall is about 7 inches; there are no perennial streams in the area. Water for mining is obtained from a few springs whose waters are not suitable for drinking owing to high salinity and a high content of selenium, molybdenum, and other toxic elements.

\section{RECENT CLIMATIC HISTORY}

Dune sand of two ages is present in the Yellow Cat area. The older sand, according to Hunt $(1956$, p. 38), was deposited before 2000 B.C. The dune sand was then stabilized during the moist period of $1500-1000$ B.C., so that the sand at present is firm and is stained with iron oxide. Later, the area was populated by potterymaking Indians who occupied sites in the area of the McCoy group of claims, on the mesas near Yellow Cat, and in the cliffs of Entrada Sandstone just south of the area. Presumably the springs in the McCoy area and in Yellow Cat were then potable. The present 
period of drought began in 1880 (Hunt, 1956, p. 38) and has been marked by renewed arroyo cutting. Younger sand that has little or no profile development covers the older sand in the lower areas. Soil development has not been able to keep pace with erosion on the cuestas and sandstone ledges, and these are principally bare rock.

Owing to the absence of residual soil in the area, wide-scale soil sampling is not a feasible method of prospecting. The roots of trees, shrubs, and many indicator plants, on the other hand, extend through the dune sands to the underlying ore horizons and can be used in prospecting for uranium ores.

\section{FAUNA AND FLORA}

The fauna of the Yellow Cat area is, as it was in Morrison time, dominantly reptilian. Lizards of many species abound in the area, and are dominated by a beautiful and agile cannibalistic form, the "boomer" or collared lizard, Crotaphytus collaris. This brilliantly colored green lizard measures more than 12 inches in length (Ditmars, 1931, p. 113), and its hind legs are twice as long as its front legs; thus enabling the lizard to rise on its hind legs and run swiftly when pursued, appearing much like a miniature Tyrannosaurus rex. The Crotaphytus eats both smaller lizards and flower blossoms.

Although the environment seems ideal for snakes, only a few bull snakes (Pituophis sayi var. bellona) and sidewinders (Crotalus cerastes) were observed. The reason for the scarcity of snakes is probably the lack of small mammals, as only a few cottontail rabbits and chipmunks live in the area. The rabbits were observed feeding on seleniferous vegetation without apparent harm.

Yellow Cat was originally named for a mountain lion killed near the spring at the old campsite. Nine large lions were hunted and killed with the aid of lion dogs in nearby country in 1951 .

Parts of the area are grazed by both sheep and cattle, but the U.S. Grazing Service does not allow use of the rest of the region because of the presence of highly toxic seleniferous vegetation. Both horses and sheep are reported to have died here from selenium poisoning.

The vegetation belongs partly to the northern-desert-shrub zone, in which blackbrush and shadscale are dominant, and partly to the mountain-woodland zone, in which juniper is dominant. The distribution of the two types of cover is governed by water supply rather than by soil type. Where the sandstone beds contain an adequate water supply, a juniper cover occurs; where a water supply is not within reach of the plant roots, xerophytic shrubs are dominant. Ecologically, the area is ideal for the growth of the abundant selenium indicator plants. All 105 species identified in the district are listed in table 1. The Latin and common names are spelled according to 
Standardized Plant Names (Kelsey and Dayton, 1942), authority and classification are according to Harrington (1954), and abbreviations are according to Rydberg (1917).

Grasses:

TABLD 1.-Flora of the Yellow Cat area, Grand County, Utah ${ }^{1}$

Gramineae:

Aristida fendleriana Steud............ Fendler threeawn

Bromus tectorum L... - ........... cheatgrass brome

Elymus salina M. E. Jones_............ salina wildrye

Festuca octoflora Walt................. . sixweeks fescue

Hilaria jamesii (Torr.) Benth. ......... galleta

Oryzopsis hymenoides (R. and S.) Rick.--- Indian ricegrass

Sitanion hystrix (Nutt.) J. G. Smith _. . . bottlebrush squirreltail

Stipa comata Trin. and Rupr.......... needleandthread

Trees and shrubs:

Gnetaceae:

Ephedra torreyana Wats.

Torrey ephedra (Mormon tea)

nevadensis S. Wats. ............ Nevada ephedra (Mormon tea)

viridis Coville _.................. green ephedra (Mormon tea)

Salicaceae:

Populus sp.......................... cottonwood

Pinaceae:

Juniperus monosperma (Engelm.) Sarg. _. - oneseed juniper Fagaceae:

Pinus cembroides var. edulis Zucc........ Colorado pinyon pine

Quercus gambelii Nutt............... Gambel oak

Chenopodiaceae:

Sarcobatus vermiculatus (Hook.) Torr....- black greasewood

Atriplex confertifolia (Torr. and Fram.)

S. Wats............ shadscale saltbush

canescens (Pursh) Nutt............ fourwing saltbush

corrugata S. Wats............... mat saltbush

Grayia spinosa (Hook.) Moq........... spiny hopsage

Rosaceae:

brandegei A. Gray ................... spineless hopsage

Amelanchier utahensis Koehne............ Utah service berry

Coleogyne ramosissima Torr............... blackbrush

Cowania stansburiana Torr............. Stansbury cliffrose

Tamaricaceae:

Tamarix gallica L................ French tamarisk

Oleaceae:

Fraxinus anomala Torr.

singleleaf ash

Compositae:

Tetradymia spinosa Hook. and Arn. cottonwood horsebrush

Artemisia tridentata Nutt............... big sagebrush

bigelovii A. Gray . .............. bigelow sagebrush

A plopappus laricifolius Gray........ larchleaf goldenweed (stenotopsis)

See footnotes at end of table. 
TABLE 1.-Flora of the Yellow Cat area, Grand County, Utah LContinued

Herbs exclusive of grasses:

Liliaceae:

Nothoscordum texanum M. E. Jones_...-. Texas falsegarlic

Calochortus nuttallii Torr.............. segolily mariposa

Allium acuminatum Hook.............. tapertip onion

Zigadenus gramineus Rydb............. grassy deathcamas

Yucca harrimaniae Trel................ Harriman yucca

Polygyonaceae:

Eriogonum gordoni Benth............. Gordon eriogonum inflatum Torr. ovalifolium Nutt. fusiforme Small deserttrumpet eriogonum cushion eriogonum

Rumex hymenosepalus Torr. eriogonum canaigre

Chenopodiaceae:

Salsola kali var. tenuifolia Tausch _. . . . - tumbling Russianthistle

Monolepis nuttalliana (Schult.) Greene _. - povertyweed or Nuttal monolepis

Nyctaginaceae:

Abronia fragrans var. elliptica Heimerl.... Snowball sandverbena

Mirabilis multiflora (Torr.) Gray _. . . . . . Colorado four-o-clock

Ranunculaceae:

Delphinium menziesi D. C.............. Menzies larkspur

Cruciferae:

Dithyrea wislizeni Engelm.............. Wislizenus spectaclepod

Stanleya pinnata (Pursh) Britt........... desert princesplume

Lepidium lasiocarpum Nutt............ pepperweed montanum Nutt............. mountain pepperweed

Thelypodium cooperi Wats............ Cooper thelypody

Streptanthella longirostris (S. Wats.) Rydb.- longbeaked twistflower wyomingensis A. Nels.............. Wyoming twistflower

Arabis pulchra M. E. Jones ex. Wats. ...- handsome rockeress Leguminosae:

Astragalus preussi A. Gray thompsonae S. Wats............. Thompson loco pattersoni A. Gray.................. Patterson loco missouriensis Nutt................ Missouri loco confertiflorus A. Gray . . . . . . . . . . . blue loco desperatus M. E. Jones .............. milkvetch chamaeleuce A. Gray ................ milkvetch amphioxys A. Gray . . . . . . . . . . . . milkvetch ceramicus Sheld.................. mottled milkvetch

Hedysarum boreale Nutt................. northern sweetvetch

Lupinus pusillus Pursh................ rusty lupine Linaceae:

Linum aristatum Engelm.............. yellow flax Polemoniaceae:

Gilia pungens Benth. granite gilia congesta (A. Gray) Rydb........... ballhead gilia leptomeria A. Gray _........... gilia (fairy trumpet) polycladon Torr...... manybranched gilia 
TABLE 1.-Flora of the Yellow Cat area, Grand County, Utah ${ }^{1}-$ Continued

Hydrophyllaceae:

Phacelia corrugata A. Nels. phacelia (scorpionweed)

Boraginaceae:

Cryptantha flava (A. Nels.) Payson......- yellow cryptanthe fulvocanescens (Gray) Payson_........ gray cryptanthe

Lappula redowskii (Hornem.) Greene _. . - stickseed

Lithospermum angustifolium Michx....... narrowleaf gromwell

Euphorbiaceae:

Euphorbia fendleri T. and G.......... Fendler sandspurge

Malvaceae:

Sphaeralcea parvifolia A. Nels..._._._. orange globemallow

Cactaceae:

Opuntia erinacea Engelm............. grizzlybear pricklypear rhodantha Schumann.............. pricklypear polyacantha Haw.................. plains pricklypear

Echinocereus coccineus Engelm........... echinocereus

Onagraceae:

Oenothera pallida Lindl................ pale eveningprimrose

Umbelliferae: caespitosa Nutt.

tufted eveningprimrose

Cymopterus acaulis (Pursh) Raf......... stemless chimaya

Scrophulariaceae:

Castilleja angustifolia Pursh............. narrowleaf paintedcup linariaefolia Benth............... Wyoming paintedcup

Plantaginaceae:

Plantago purshi R. and S.............. wooly Indianwheat

Compositae:

Aster venustus M. E. Jones

woody aster

Solidago petradoria Blake. rock goldenrod

Bahia nudicaulis A. Gray bahia

Artemisia spinescens D. C. Eaton........ bud sagebrush

Grindelia fastigiata Greene............ erect gumweed

Grindelia squarrosa (Pursh) Dunal_...... curlycup grindelia decumbens Greene. gumweed

Senecio uintahensis (A. Nels.)

Greenman. uinta groundsel

longilobus Benth threadleaf groundsel

A plopappus armeriodes (Nutt.) Gray ..... goldenweed

Gutierrezia divaricata (Nutt.)

T. and G. spreading snakeweed

Chrysothamnus viscidiflorus (Hook.)

Nutt. Douglas rabbitbrush

greenei (A. Gray) Greene Greene rabbitbrush

Townsendia incana Nutt. hoary townsendia

Chaenactis carphoclinia A. Gray false yarrow

Hymenopappus filifolius Hook. fine-leafed hymenopappus

Actinea acaulis (Pursh) Spreng. stemless actinea

Lactuca canadensis $\mathrm{L}$. Canada wild lettuce

Enceliopsis nutans (Eastw.) A. Nels._._._. enceliopsis

\footnotetext{
1 Plant specimens collected by Mary E. Durrell, R. M. Stillman, and H. L. Cannon. Many identifications checked by Arthur Holmgren of Utah State Agricultural College.
} 
Although the climate is at present too dry to support the growth of pinyon, one 13-inch dwarfed specimen was found in the area as a lone survivor from wetter days. Scrub oak is dwarfed everywhere to a height of 6 inches. Generally, sandstone outcrops are preferred by juniper, oak, shadscale, cliffrose, and ash, whereas clay alluvium and dune sand are preferred by blackbrush, Mormon tea, sandverbena, woody asters, and blue loco.

The distribution of plants is controlled primarily by the topography and ground-water conditions and, secondarily, by the chemistry of the rocks and soils. Selenium and gypsum indicator plants are more abundant near ore deposits, and, conversely, sagebrush, hopsage, and other plants that are intolerant of high salt content in the soil are restricted to unmineralized areas. This relation between the chemistry of the ores at depth and the vegetation at the ground surface forms the basis for botanical methods of prospecting.

\section{GROUND-WATER CONDITIONS}

The true ground-water table in the Yellow Cat area lies well below the ground surface. There are no perennial streams, and the few springs are related to facies changes that have given rise locally to perched water tables. The ore bodies generally occur along linear zones of high permeability and transmissibility in sandstone (Phoenix, 1959), and present-day ground water may occupy similar channels. Thus, the ore bodies are commonly saturated with water. Unusually large amounts of water trapped by clay seams and other lithologic traps were found over a considerable area by drilling in the McCoy group of claims, in Pittsburg Park just east of the old Yellow Cat Campsite, and on Memphis Hill in a graben (pl. 3).

Perennial plants that obtain water from the water table have been called phreatophytes, in contrast to xerophytes, which utilize soil moisture in the zone of aeration above the water table (Meinzer, 1923, p. 95). Of the plants listed in table 1, species of Populus (cottonwood), Tamarix (tamarisk), Aplopappus (goldenweed), Atriplex (saltbush), Sarcobatus (greasewood), Elymus (wildrye), Fraxinus (ash), and Chrysothamnus (rabbitbrush) are known to be phreatophytes (Meinzer, 1927, p. 77). In addition, Cowania stansburiana (Stansbury cliffrose) and Juniperus (juniper) in the Yellow Cat area also indicate available ground water in this semiarid environment. A new herbaceous phreatophyte was discovered during the drilling on Memphis Hill. Here, Hedysarum boreale Nutt. was mistaken for an Astragalus, a selenium indicator plant, and was used as a guide in locating drilling sites. In every hole drilled on the basis of this plant, artesian water was found. These plants were included by Robinson (1958) in the 1958 listing of phreatophytes.

721-926 0-64-2 
Juniper predominates on the mesa capped by a water-bearing sandstone at the McCoy group of claims, and cliffrose predominates on the mesa south of the Cactus Rat group of claims. Where ground water is not available, as on Yellow Cat Mesa, the xerophyte shadscale grows to the exclusion of practically all other plants.

\section{GEOLOGY}

\section{GEOLOGIC SETTING}

The Yellow Cat area is northwest of the La Sal Mountains and east of the Salt Valley anticline-one of a series of northwest-trending salt anticlines that lie to the southwest of the Uncompahgre uplift. The area of the salt anticlines coincides with that part of the Paradox Basin in which occur the thickest evaporite deposits in the Paradox Member of the Hermosa Formation of Pennsylvanian age. Deformation by flowage of the salt to form the present structures is generally considered to have begun in Late Pennsylvanian or Permian time and to have continued intermittently into the early Tertiary.

Structurally, the Yellow Cat area lies across a gently anticlinal nose of generally north- and northwest-dipping rocks. The area lies between Salt Valley anticline and Sagers Wash syncline-a gentle downwarp between the Uncompahgre uplift and the belt of salt structures. The Yellow Cat dome, which has an estimated closure of about 100 feet (Dane, 1935, p. 127; Stokes, 1952a, p. 21), occurs southeast and south of the major uranium deposits in the area. The dome is cut by several high-angle faults of small displacement that extend west-northwestward into the mineralized area. Two of the faults contribute to the ore potential, as they form a graben in which the deposits of Memphis Hill have been preserved. Several mines are along the faults, but no relation between the faults and the origin of the ores can be demonstrated.

\section{STRATIGRAPHY}

The rocks exposed in the Yellow Cat area consist mainly of the Brushy Basin Shale Member and the underlying Salt Wash Sandstone Member of the Morrison Formation of Late Jurassic age (table 2). The stratigraphic relations were discussed in detail by Dane (1935) and Stokes (1952a). The rocks crop out in a steplike series of flattopped mesas and ledges formed on the sandstone beds of the Salt Wash Member. This member, which is fluvial in origin, consists of four or more beds of lenticular crossbedded sandstone that are $20-50$ feet thick and are separated by layers of mudstone of variable thickness. 
TABLE 2.-Rocks exposed in the Yellow Cat area

\begin{tabular}{|c|c|c|c|}
\hline Series & \multicolumn{2}{|c|}{ Formation and member } & Character \\
\hline 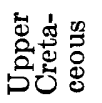 & \multicolumn{2}{|c|}{$\begin{array}{l}\text { Dakota Sandstone } \\
\quad( \pm 90 \mathrm{ft})\end{array}$} & Massive sandstone and conglomerate. \\
\hline \multirow{2}{*}{ 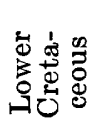 } & \multirow{2}{*}{\multicolumn{2}{|c|}{$\begin{array}{l}\text { Cedar Mountain } \\
\text { Formation } \\
(40-100 \mathrm{ft})\end{array}$}} & Mudstones forming slopes. \\
\hline & & & $\begin{array}{l}\text { Sandstone and conglomerate which caps the } \\
\text { escarpment, locally converted to quartzite. }\end{array}$ \\
\hline \multirow{10}{*}{ 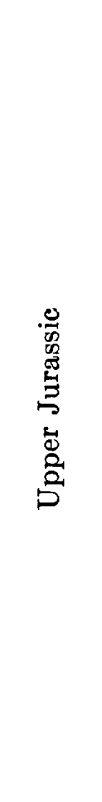 } & \multirow{9}{*}{ 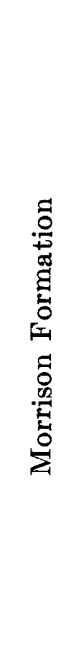 } & $\begin{array}{l}\text { Brushy Basin } \\
\text { Shale } \\
\text { Member } \\
( \pm 290 \mathrm{ft})\end{array}$ & $\begin{array}{l}\text { Variegated bentonitic mudstone and sand- } \\
\text { stone lenses. }\end{array}$ \\
\hline & & \multirow{8}{*}{$\begin{array}{l}\text { Salt Wash } \\
\text { Sandstone } \\
\text { Member } \\
( \pm 260 \mathrm{ft})\end{array}$} & $\begin{array}{l}\text { Bed } 1 \text {, coarse brown conglomerate containing } \\
\text { red and green chert pebbles. }\end{array}$ \\
\hline & & & Blue bentonitic mudstone. \\
\hline & & & Bed 2, crossbedded sandstone. \\
\hline & & & Red mudstone. \\
\hline & & & Bed 3, fine-grained impure sandstone. \\
\hline & & & Red mudstone. \\
\hline & & & Bed 4 , main ore-bearing massive sandstone. \\
\hline & & & $\begin{array}{l}\text { Red mudstones and sandstones (including } \\
\text { bed 5) interbedded. }\end{array}$ \\
\hline & \multicolumn{2}{|c|}{$\begin{array}{c}\text { Summerville } \\
\text { Formation } \\
(35-60 \mathrm{ft})\end{array}$} & Red mudstone and siltstone. \\
\hline
\end{tabular}

According to Cadigan (1959, p. 20), "The sandstones are composed of quartz, potash feldspar, sodic feldspar, silicified and altered tuff, chert, metamorphic rock fragments, and rhyolitelike igneous rock fragments and hydromica, montmorillonite, and kaolinite clay minerals." Calcite is the common cement, but silica occurs as overgrowths on quartz. The sandstones, which are exposed successively in descending stratigraphic order toward the south, are numbered arbitrarily for drilling reference as beds 1-5 downward from the top of the Salt Wash. The shales or mudstones are predominantly red but are generally altered to blue green in the vicinity of ore deposits. The works of Cadigan (1959) and of Waters and Granger (1953) suggest a volcanic origin. Glass shards can be recognized. The overlying Brushy Basin Shale Member consists of about 300 feet of mud- 
stones interbedded with small sandstone lenses. These mudstones have been eroded from most of the area but are exposed in a steep escarpment along the north edge of the district. The cliff, according to Stokes (1952a, p. 20;1952b, p. 1775), is capped by sandstones of the Cedar Mountain Formation of Early Cretaceous age, although the Yellow Cat area is about on the border between the facies of the Cedar Mountain and Burro Canyon (L. C. Craig, oral communication, 1960). The Dakota Sandstone caps a second escarpment of slopeforming shales in the upper part of the Cedar Mountain Formation.

The ore deposits occur in the Salt Wash Member in the five sandstone beds shown in table 2. Prospecting and exploration described in this report are confined to the outcrop area of these five beds at the base of the escarpment. Bed 1, the coarse conglomerate which contains the Cactus Rat deposit, School Section claims, and Windy Point claims, has been considered by some workers as part of the Salt Wash and by others as part of the Brushy Basin. The conglomerate is brown and contains red and green chert pebbles. It does not form a continuous sheet throughout the district but represents a series of anastomosing channel fillings of the same age as the underlying bentonitic green mudstone. The mudstone varies in thickness and grades laterally into fine powdery white sandstone. Stoke's (1952a, p. 12) placement of the conglomerate at the top of the Salt Wash Sandstone Member rather than in the basal part of the Brushy Basin Shale Member is probably correct, as the conglomerate and the bed 2 sandstone are actually transposed in an exposure in the eastern part of the area.

Bed 2 is a massive resistant sandstone that contains many of the silicified rock fragments like those described by Cadigan (1959). It caps the higher mesas in the western part of the area. Ores of the Little Pittsburg group on Yellow Cat Mesa and ores of the Flattop group are in this sandstone.

Bed 3, which is thinner than bed 2, is an impure sandstone that contains many mudstone partings; in the Cactus Rat area, outcrops of bed 3 characteristically weather to rounded, spalled surfaces.

Bed 4 is a massive sandstone that is usually underlain and overlain by red mudstone, altered to greenish blue where the sandstone is mineralized. The sandstone itself may be bleached near the ore. Bed 4 is the ore-bearing unit at the Yellow Cat Campsite, and it is also present to the south where it is repeated by faulting on Memphis Hill.

Bed 5 comprises several lower thin sandstones, separated by red mudstones, that crop out between bed 4 and the Summerville Formation to the south. Several small ore deposits occur in these beds, but as no ore deposits of significance are known, bed 5 was not investigated in the drilling program. 


\section{ORE DEPOSITS}

The ore bodies are tabular, elongated masses that occur along what appear to be water channelways in the host sandstone beds. The ore contains about 2 percent $\mathrm{V}_{2} \mathrm{O}_{5}, 0.25$ percent $\mathrm{U}_{3} \mathrm{O}_{8}$, and lesser amounts of selenium, molybdenum, nickel, and cobalt. The ore bodies are as much as 12 feet thick and 5-200 feet long, and they contain from a few hundred to several thousand tons of ore. The ore is commonly concentrated around organic material in the ore-bearing channels of the sandstone. The habits of the ore bodies in relation to the sandstones were described in detail by Fischer (1942) and Stokes (1952a).

In oxidized deposits above the present water table, the principal uranium-vanadium minerals are carnotite, tyuyamunite, roscoelite, corvusite, and vanadium hydromica. These minerals are associated with gypsum, selenates, and many secondary uranium-vanadium salts.

Unoxidized deposits below the water table contain the so-called black ore composed of pitchblende, coffinite, and montroseite associated with metallic sulfides and selenides. In the Yellow Cat area, several mines, such as the Juniper, contained black sulfide ore at a comparatively shallow depth where mudstone splits in the sandstone locally protected the ore from oxidation.

At the Cactus Rat deposit, which represents a third type, the ore is in a highly organic ancient swamp deposit in which so many dinosaurs became mired that the deposit might be called a dinosaur boneyard. Rare minerals in this deposit include rauvite, corvusite, metahewettite, steigerite, phosphuranylite, and a sodium equivalent of hewettite. Weeks and Thompson (1954) believed that these minerals owe their origin to sodium leaching from the overlying Brushy Basin Shale Member.

\section{GEOCHEMISTRY}

\section{COLLECTION AND ANALYSIS OF ROCK AND SOIL SAMPLES}

A great number of rock and soil samples were collected and analyzed in 1949 and 1950 to determine whether selenium, molybdenum, or some other element could be used as a pathfinder element in the search for uranium-vanadium deposits on the Colorado Plateau. This study centered around rock samples collected by Louis C. Rove, Jr., from 13 ore bodies and the enclosing barren sandstones and clays in the Yellow Cat area and comparable collections from 5 ore bodies in the Uravan mineral belt, Colorado. Channel samples were taken at the outcrop through the barren sandstone both above and below the mineralized part of the ore bed, and, wherever possible, sampling was continued into the underlying altered mudstone. Information on 
lateral variations was obtained by taking a similar channeled section several hundred feet along the strike from the ore outcrop. Particular attention was paid to the radioactivity and chemical composition of the first inch of altered mudstone underlying the ore-bearing sandstone. Some of the samples collected in the Yellow Cat area were from outcrops, and some were from drill cores; those collected in the Uravan mineral belt for comparison were entirely from drill cores. A few additional samples, particularly of mudstones, were collected in Yellow Cat in 1957 and 1958.

The samples were analyzed fluorimetrically for uranium and chemically for vanadium selenium, sulfur, calcium carbonate, and iron by G. T. Burrow, R. G. Havens, C. H. Huffman, Jr., J. W. Harbaugh, H. E. Crowe, J. H. McCarthy, Jr., G. W. Boyes, and R. F. Dufour. The samples were analyzed spectrographically for manganese, nickel, cobalt, copper, lead, molybdenum, silver, arsenic, chromium, and zinc by A. T. Myers, P. R. Barnett, J. C. Hamilton, and E. F. Cooley. The results of these analyses were transferred to punch cards, and correlation coefficients were computed by Gwen W. Luttrell. In the accompanying charts the values are compared in several different ways by arithmetic means.

\section{SALT WASH MEMBER OF THE MORRISON FORMATION}

\section{SANDSTONES SURROUNDING ORE DEPOSITS}

The Salt Wash Sandstone Member in the Yellow Cat area is composed of sandstone beds of high permeability separated by mudstones or, in some places, siltstones (Weeks, 1953) of low permeability. The Salt Wash is overlain by red and green mudstones and thin sandstone beds of the Brushy Basin Shale Member. Twenty samples of sandstone classed as unmineralized and 8 samples classed as weakly mineralized were collected above, below, or along the strike from ore in 5 beds in the Yellow Cat area. For comparison, 12 samples were similarly collected from the upper sandstone of the Salt Wash in the Uravan mineral belt. An additional 67 unmineralized and 159 weakly mineralized samples became available during the Yellow Cat drilling program and were analyzed for uranium, vanadium, and selenium; these analyses have been included in the averages.

All analyses presented in this paper whether chemical or spectrographic, are quantitative. Therefore, because the precision is high, the arithmetic means have been computed not by the Sickel method but by dividing the sum by the number of assays; the Sickel method, in which the functions of the mean log of analyses and the variance of the logs are used, was employed by Shoemaker and others (1959).

Arithmetic means for eight elements for which there are significant figures are shown in table 3 . The analyses of the sandstone 
TABLE 3.-Chemical composition, in parts per million, of unmineralized sandstones collected near ore in the Yellow Cat area and Uravan mineral belt compared with that of average sandstones

\begin{tabular}{|c|c|c|c|c|}
\hline Element & $\begin{array}{l}\text { A verage sandstones } \\
\text { of the earth's crust } 1\end{array}$ & $\begin{array}{l}\text { A verage barren } \\
\text { sandstones of the } \\
\text { Salt Wash of Colo- } \\
\text { rado Plateaul } 2\end{array}$ & $\begin{array}{c}\text { Unmineralized } \\
\text { sandstones of the } \\
\text { Salt Wash within } \\
\text { Uravan mineral belt } \\
\text { (12 samples }{ }^{3} \text { ) }\end{array}$ & $\begin{array}{l}\text { Unmineralized } \\
\text { sandstones of the } \\
\text { Salt Wash within } \\
\text { Yellow Cat area } \\
\text { (20 samples) }\end{array}$ \\
\hline $\begin{array}{l}\mathrm{Fe} \\
\mathrm{Ca} \\
\mathrm{M} \mathrm{M} \\
\mathrm{S} \\
\mathrm{Cu} \\
\mathrm{Cr} \\
\mathrm{Pb} \\
\mathrm{V} \\
\mathrm{As} \\
\mathrm{U}\end{array}$ & $\begin{array}{c}9,900 \\
39,000 \\
\text { Trace } \\
12,800 \\
434 \\
68-200 \\
20 \\
20 \\
42.6 \\
1.2 \\
.44\end{array}$ & $\begin{array}{r}3,200 \\
64,000 \\
400 \\
200 \\
25 \\
15 \\
\approx 1 \\
18 \\
\approx 9 \\
\quad 1 \\
\approx .5 \\
\approx .5 \\
\approx .05\end{array}$ & $\begin{array}{c}14,000 \\
400 \\
16 \\
13 \\
<4 \\
400 \\
18 \\
11 \\
2.3 \\
26 \\
<1\end{array}$ & $\begin{array}{r}15,000 \\
28,000 \\
600 \\
430 \\
7 \\
\approx 73 \\
<12 \\
580 \\
\approx 32 \\
13 \\
14 \\
7.9 \\
<1.1\end{array}$ \\
\hline
\end{tabular}

1 Rankama and Sahama (1950, p. 226).

2 Miesch, A. T. (written communication, 1961).

3 Compiled from sandstone samples collected above, below, and along the strike from known ore deposits.

4 Clarke (1924, p. 509).

surrounding ore in the Yellow Cat area are similar to those of sandstone collected at the same distance from ore in the Uravan mineral belt. Uranium, vanadium, iron, arsenic, and chromium are more abundant and copper and calcium are less abundant than in the unmineralized sandstones collected by Shoemaker and others (1956, p. 23) at a greater distance from ore deposits. The data suggest a halo of certain of the ore elements in the surrounding sandstones that might be a useful guide in prospecting. A similar increase in metal content in the bleached areas of the Chinle Formation near ore deposits was described by Huff (1954). Vanadium, uranium, arsenic, iron, and manganese are more abundant in bleached areas than in an average sandstone as given by Rankama and Sahama (1950, p. 226) and by Clarke (1924, p. 509).

The distribution of metals between an ore body and the ground surface was also investigated by sampling an open pit at the Parko 23-2 mine. This deposit was found by drilling in areas where the indicator plant Astragalus pattersoni grows; formerly the presence of red mudstone in the section in this area was thought to indicate unfavorable ground for ore deposits, hence the area was not explored by other measures. The ore was mined to a depth of 44 feet by open-pit methods, and an inclined shaft was dug downward from the bottom of the pit. The ore body was estimated from Survey drilling to contain 6,600 tons of minable ore (C. M. Mobley and E. S. Santos, written communication, 1956). The analyses of samples are given in table 4 and are shown on graphs in figures 2 and 3. 


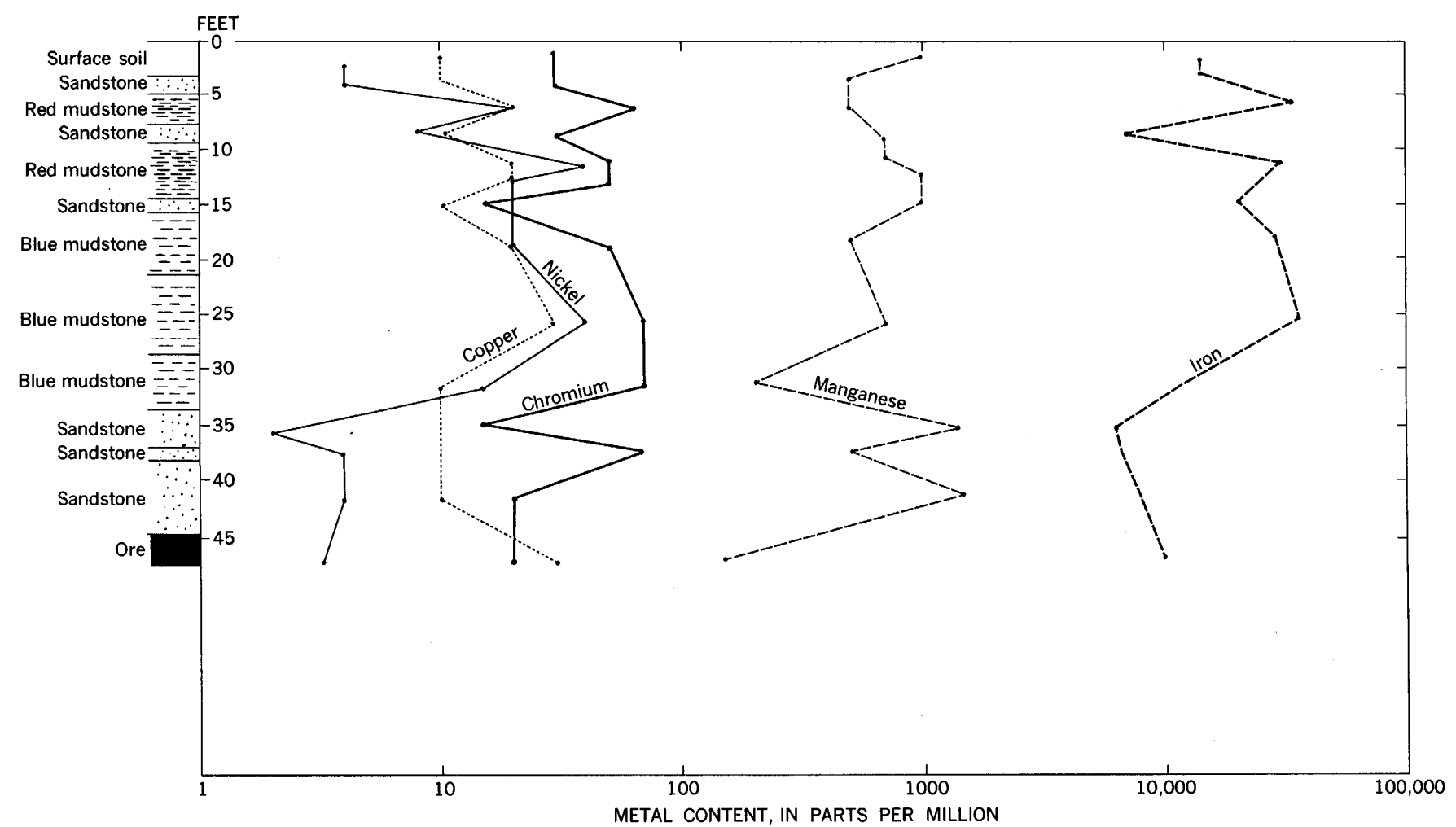




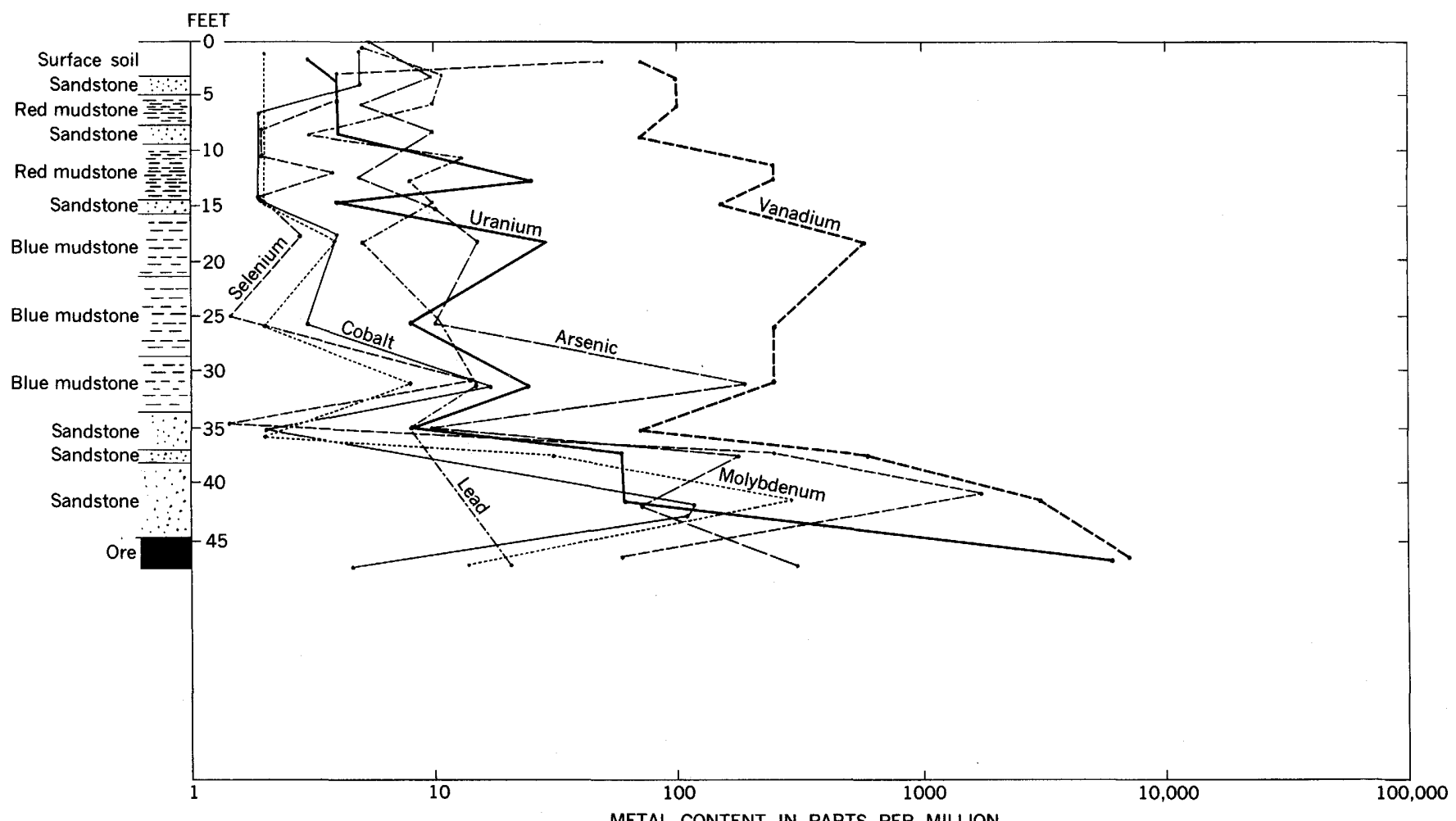

FiguRe 3.-Distribution of vanadium, selenium, molybdenum, arsenic, uranium, cobalt, and lead in sedimentary rocks and soil above ore body in open-pit Parko 23-2 mine. 
$\mathrm{T}_{\mathrm{ABLE}}$ 4.-Metal content, in parts per million, in sedimentary rocks and soil above ore body in Parko 23-2 open pit

[Analysts: E. F. Cooley, E. A. Smith, H. E. Crowe, H. M. Nakagawa, C. E. Thompson, and G. T. Burrowi

\begin{tabular}{|c|c|c|c|c|c|c|c|c|c|c|c|c|c|}
\hline $\begin{array}{l}\text { Laboratory } \\
\text { No. }\end{array}$ & $\begin{array}{c}\text { Description and } \\
\text { thickness of } \\
\text { bed }\end{array}$ & $\mathrm{U}$ & V & Se & Mo & $\mathrm{Cu}$ & As & $\mathrm{Pb}$ & $\mathrm{Co}$ & $\mathrm{Ni}$ & $\mathrm{Fe}$ & $\mathrm{Cr}$ & Mu \\
\hline GX-56-2590 & $\begin{array}{l}\text { Sandy soil, } 1 / 4-3 \\
\mathrm{ft} .\end{array}$ & $<4$ & 70 & 15 & 2 & 10 & $<10$ & 5 & 5 & 4 & 14,000 & 30 & 1,000 \\
\hline 2591 & $\begin{array}{l}\text { Sandidstone, 3-41/2 } \\
\mathrm{ft} \text {. }\end{array}$ & 4 & 100 & 4 & 2 & 10 & 10 & 11 & 5 & 4 & 14,000 & 30 & 500 \\
\hline 2592 & Red mudstone, & 4 & 100 & 4 & 2 & 20 & $<10$ & 10 & 2 & 20 & 34,000 & 70 & 500 \\
\hline 2593 & $\begin{array}{l}\text { Siltstone, } 71 / 2- \\
91 / 4 \mathrm{ft}\end{array}$ & 4 & 70 & $<2$ & 2 & 10 & 10 & 3 & $<2$ & 8 & 6,400 & 30 & 700 \\
\hline 2594 & $\begin{array}{l}\text { Red mudstone, } \\
91 / 4-121 / 4 \mathrm{ft}\end{array}$ & 8 & 250 & $<2$ & 2 & 20 & $<10$ & 13 & 2 & 40 & 29,000 & 50 & 700 \\
\hline 2595 & $\begin{array}{l}\text { Red mudstone, } \\
121 / 4-14 \mathrm{ft}\end{array}$ & 25 & 250 & 4 & 2 & 20 & $<10$ & 8 & 2 & 20 & 26,000 & 50 & 1,000 \\
\hline 2596 & $\begin{array}{l}\text { Gray sandstone, } \\
14-15 \mathrm{ft} .\end{array}$ & 4 & 150 & 2 & 2 & 10 & 10 & 10 & 2 & 20 & 20,000 & 15 & 1,000 \\
\hline 2589 & $\begin{array}{l}\text { Mineralized } \\
\text { gray sand- } \\
\text { stone, } 371 / 2- \\
44 \mathrm{ft}\end{array}$ & 60 & 3,000 & $>1,500$ & 300 & 10 & 80 & 13 & 120 & 4 & 8,000 & 20 & 1,500 \\
\hline 1895 & $\begin{array}{l}\text { Ore from in- } \\
\text { clined shaft in } \\
\text { bottom of pit.- }\end{array}$ & 6,000 & 5,000 & $-1,000$ & 15 & 30 & 400 & 500 & 15 & 10 & 15,000 & 20 & 1,500 \\
\hline $\begin{array}{c}58-877 \\
\mathrm{GX}-56-2597\end{array}$ & Blue mudstone & 3,000 & 10,000 & 20 & 20 & 20 & 120 & 20 & $<10$ & $<5$ & 10,000 & 20 & 150 \\
\hline & Bitue mudstone, & 30 & 600 & 3 & 4 & 20 & 15 & 5 & 4 & 20 & 28,000 & 50 & 500 \\
\hline 2598 & $\begin{array}{l}\text { Blue mudstone, } \\
21-281 / 4 \mathrm{ft}\end{array}$ & 8 & 250 & $<2$ & 2 & 30 & 10 & 10 & 3 & 40 & 35,000 & 70 & 700 \\
\hline 2599 & $\begin{array}{l}\text { Blue mudstone, } \\
281 / 4-33 \mathrm{ft}\end{array}$ & 25 & 250 & 15 & 8 & 10 & 200 & 15 & 15 & 15 & 12,000 & 70 & 200 \\
\hline 2600 & $\begin{array}{l}\text { Bed 4: coarse- } \\
\text { grained sand- } \\
\text { stone, } 33-361 / 2 \\
\text { ft }\end{array}$ & 8 & 70 & $<2$ & 2 & 10 & 15 & 8 & 2 & 2 & 6,400 & 15 & 1,500 \\
\hline 2601 & $\begin{array}{l}\text { Bed 4: coarse- } \\
\text { grained sand- } \\
\text { stone, } 36-371 / 2 \\
\text { ft }\end{array}$ & 60 & 600 & 300 & 30 & 10 & 175 & 9 & 10 & 4 & 6,800 & 70 & 500 \\
\hline
\end{tabular}

Only selenium and possibly manganese were found to be concentrated in the surface soil, 44 feet above the ore. A selenium concentration of $15 \mathrm{ppm}$, if mainly in soluble form, is enough to permit seedling selenium indicator plants to get a start. Once started, roots of Astragalus are known to penetrate easily to depths of 30 feet and, in faulted and jointed rocks, much deeper. Roots of a plant believed to be an Astragalus were dug out of the rock from the inclined shaft at a depth of more than 60 feet below the ground surface. The accumulation of selenium in the surface soil is believed to be caused by the decay of the Astragalus plants.

Selenium, cobalt, and molybdenum are more concentrated through $6 \frac{1}{2}$ feef of beds immediately above the ore body than in the ore itself. Nickel, copper, and particularly iron are more abundant in the mudstones than in the sandstones but are not enriched in the ore. Total uranium and vanadium contents are higher than average in most beds for a distance of 34 feet above the ore (or within $10 \mathrm{ft}$ of the surface). The percentage of leachable uranium is not known, but it probably is high through these beds. Work by Holland and others $(1957,1958)$ 
suggested that in areas where uranium ore lies within 30 feet of the ground surface, leachable uranium in the surface soil can be used as an indicator of ore at depth. Similar studies by Miesch and Connor (1956) showed a detectable anomaly in total uranium and leachable vanadium, lead, and zinc for 500 feet along the strike and for 28 feet vertically toward the ground surface from ore. They believed that the anomaly could be used to outline areas favorable for prospecting. Differences in cobalt, nickel, arsenic, selenium, and molybdenum contents were below their limits of detection.

\section{SANDSTONES OF THE ORE DEPOSITS}

\section{CONCENTRATION AND ABUNDANCE OF ELEMENTS}

The ore samples collected in the Yellow Cat area contained, as shown in table 5, the following anomalous contents of metals: About $9,500 \mathrm{ppm}$ vanadium, $7,300 \mathrm{ppm}$ sulfur, $3,800 \mathrm{ppm}$ uranium, 400 ppm arsenic, $200 \mathrm{ppm}$ zinc, $200 \mathrm{ppm}$ selenium, $100 \mathrm{ppm}$ molybdenum, $60 \mathrm{ppm}$ cobalt, $50 \mathrm{ppm}$ lead, $30 \mathrm{ppm}$ nickel, $20 \mathrm{ppm}$ copper, and 3 ppm silver. Calcium carbonate and manganese contents were lower in the ore than in the surrounding unmineralized sandstone. The composition of the ores as compared with the composition of the average mill pulp on the Colorado Plateau is shown in table 6. The Yellow Cat samples contained considerably more iron, uranium, sulfur, zinc, arsenic, selenium, chromium, cobalt, and nickel but less calcium, manganese, copper, and lead. Calculated abundance ratios show that several hundred times more uranium; 12-17 times more vanadium, sulfur, selenium, arsenic, and molybdenum; and 4-7 times more cobalt, nickel, and lead are concentrated in the ore than in the surrounding barren rock. Least abundant are copper, iron, silver, and zinc. The values for four constituents are shown in table 7 by source of sample-collected from outcrops or from drill cores. The mean values suggest leaching of uranium and calcium carbonate from, and enrichment of vanadium and selenium in, ore outcrops. Although hexavalent vanadium and pentavalent uranium are usually associated in such insoluble minerals as carnotite, tyuyamunite, and rauvite, a mechanism to explain the leaching was given by Garrels and Christ $(1959$, p. 88$)$. They stated that uranyl ions form soluble uranylcarbonate complexes in the presence of moderate or abundant carbonate ions and, further, that "The thin soils of the Plateau area are very high in carbonates, attesting the continuous upward migration of carbonates by a capillary process. Under these optimum conditions for the formation of soluble uranyl carbonate complexes uranium may be leached even from carnotite." Hydrated uranyl carbonates that have been precipitated from ground water are commonly observed in drainage areas throughout the district, and schroeckingerite has been 
TABLE 5.-Trace elements, in parts per million, in sandstones of the Yellow Cat Area [Analysts: P. R. Barnett, A. T. Myers, C. H. Huffman, Jr., J. W. Harbough, R. G. Havens, H. E. Crowe, R. R. Beins, S. P. Furman, R. F. Dufour, and Harold Bloom]

\begin{tabular}{|c|c|c|c|c|c|c|c|c|c|c|}
\hline \multirow{2}{*}{ Element } & \multicolumn{3}{|c|}{$\begin{array}{l}\text { Unmineralized sandstone } \\
\left(<40 \mathrm{U} \text { or } 50 \mathrm{U}_{3} \mathrm{O}_{8}\right)\end{array}$} & \multicolumn{3}{|c|}{$\begin{array}{l}\text { Mineralized sandstone } \\
\left(50-1,000 \mathrm{U}_{3} \mathrm{O}_{8} \text { or } 40 \mathrm{U}-840 \mathrm{U}\right)\end{array}$} & \multicolumn{3}{|c|}{$\begin{array}{l}\text { Ore sandstone }\left(>1,000 \mathrm{U}_{3} \mathrm{O}_{8} \text { or }\right. \\
\left.10,000 \mathrm{~V}_{2} \mathrm{O}_{5}>840 \mathrm{U} \text { or } 5,600 \mathrm{~V}\right)\end{array}$} & \multirow{2}{*}{$\begin{array}{l}\text { Abundance } \\
\text { ratio } \\
\text { (ore/barren) }\end{array}$} \\
\hline & $\begin{array}{c}\text { Number of } \\
\text { samples }\end{array}$ & Range & Mean & $\begin{array}{c}\text { Number of } \\
\text { samples }\end{array}$ & Range & Mean & $\begin{array}{l}\text { Number of } \\
\text { samples }\end{array}$ & Range & Mean & \\
\hline $\begin{array}{l}\mathrm{J}{ }^{1} \\
\mathrm{~V} \\
\mathrm{CaCO} \\
\mathrm{Se} \\
\mathrm{As} \\
\mathrm{M}{ }_{\mathrm{O}}\end{array}$ & $\begin{array}{l}87 \\
87 \\
22 \\
87 \\
18 \\
20 \\
3 \\
20 \\
20 \\
20 \\
20 \\
18 \\
14 \\
20 \\
20 \\
14\end{array}$ & $\begin{array}{rr}1- & 30 \\
60- & 9,400 \\
4,000-209,000 \\
<.5- & 750 \\
<10- & 150 \\
<1- & 50 \\
300- & 600 \\
<2- & 60 \\
<1- & 20 \\
<3- & 200 \\
6- & 30 \\
3,200- & 30,000 \\
<1- & 3 \\
<3- & 460 \\
30- & 2,000 \\
<50- & 250\end{array}$ & $\begin{aligned} 13 \\
578 \\
71,000 \\
<14 \\
\approx 32 \\
\approx 7.9 \\
430 \\
<8 \\
<5 \\
<12 \\
7 \\
15,000 \\
<1.1 \\
\approx 73 \\
632 \\
<89\end{aligned}$ & $\begin{array}{r}167 \\
167 \\
58 \\
167 \\
6 \\
8 \\
2 \\
2 \\
8 \\
8 \\
8 \\
9 \\
9 \\
6 \\
8 \\
8 \\
6\end{array}$ & $\begin{array}{rr}40- & 800 \\
500- & 6,000 \\
2,000-199,000 \\
<.04->1,500 \\
30- & 250 \\
<1- & 300 \\
500- & 2,300 \\
10- & 120 \\
4- & 80 \\
2- & 50 \\
1- & 30 \\
6,800- & 18,000 \\
<1- & 3 \\
7- & 200 \\
50- & 1,000 \\
<50- & 100\end{array}$ & $\begin{array}{r}183 \\
1,280 \\
46,000 \\
\approx 51 \\
100 \\
41 \\
1,400 \\
45 \\
23 \\
11 \\
9 \\
19,000 \\
<1 \\
76 \\
338 \\
\approx 71\end{array}$ & $\begin{array}{r}58 \\
58 \\
49 \\
58 \\
22 \\
22 \\
6 \\
22 \\
22 \\
22 \\
22 \\
22 \\
22 \\
22 \\
22 \\
22\end{array}$ & $\begin{array}{rr}40-22,300 \\
560-35,800 \\
3,000-106,000 \\
1- & <700 \\
30- & 1,800 \\
1- & 800 \\
400- & 25,500 \\
<5- & 200 \\
<4- & 200 \\
3- & 500 \\
1- & 50 \\
100- & 70,000 \\
44- & 30 \\
5- & 800 \\
30- & 2,000 \\
20- & 900\end{array}$ & $\begin{array}{r}3,800 \\
9,510 \\
30,700 \\
190 \\
420 \\
100 \\
7,300 \\
\approx 59 \\
\approx 35 \\
52 \\
23 \\
28,200 \\
3.5 \\
107 \\
292 \\
\approx 228\end{array}$ & $\begin{array}{r}292.3 \\
16.4 \\
.4 \\
13.5 \\
>13 \\
>12.5 \\
16.9 \\
>6.5 \\
>7 \\
>4.5 \\
3.3 \\
1.9 \\
>3 \\
1.4 \\
>46 \\
>2.56\end{array}$ \\
\hline
\end{tabular}

$1 \mathrm{eU}$ values were used where $\mathrm{U}$ values were not available. 
mined from the McCoy group. The result of oxidation of the selenium is probably, according to Lakin and Trites (1958), an insoluble ferric selenite.

TABLE 6.-Mean composition, in parts per million, of ores collected in Yellow Cat area compared with that of mill pulp (average) from Colorado Plateau

\begin{tabular}{|c|c|c|}
\hline Element & $\begin{array}{l}\text { Mill pulp from } \\
\text { Colorado } \\
\text { Plateau } 1\end{array}$ & $\begin{array}{l}\text { Ores of Yellow } \\
\text { Cat area }\end{array}$ \\
\hline 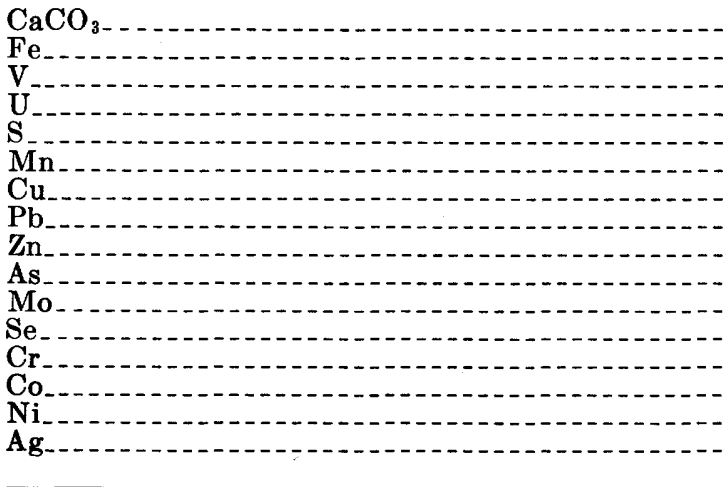 & $\begin{array}{r}33,000 \\
9,900 \\
8,500 \\
2,200 \\
1,200 \\
470 \\
230 \\
190 \\
170 \\
170 \\
\sim 60 \\
50 \\
21 \\
19 \\
16 \\
2\end{array}$ & $\begin{array}{r}30,700 \\
28,200 \\
9,510 \\
3,800 \\
7,300 \\
292 \\
23 \\
52 \\
228 \\
417 \\
100 \\
190 \\
107 \\
59 \\
35 \\
3.5\end{array}$ \\
\hline
\end{tabular}

${ }^{1}$ A. T. Miesch (written communication, 1961).

TABLE 7.-Uranium, vanadium, selenium, and carbonate contents, in parts per million, of outcrop samples compared with contents of core samples from the Yellow Cat area

\begin{tabular}{|c|c|c|c|c|c|c|c|c|c|c|c|c|}
\hline \multirow{2}{*}{ Element } & \multicolumn{4}{|c|}{ Barren sandstone } & \multicolumn{4}{|c|}{ Mineralized sandstone } & \multicolumn{4}{|c|}{ Ore sandstone } \\
\hline & $\begin{array}{c}\text { Num- } \\
\text { ber of } \\
\text { outerop } \\
\text { samples }\end{array}$ & Mean & $\begin{array}{c}\text { Num- } \\
\text { ber of } \\
\text { core } \\
\text { samples }\end{array}$ & Mean & $\begin{array}{c}\text { Num- } \\
\text { ber of } \\
\text { outcrop } \\
\text { samples }\end{array}$ & Mean & $\begin{array}{c}\text { Num- } \\
\text { ber of } \\
\text { core } \\
\text { samples }\end{array}$ & Mean & $\begin{array}{c}\text { Num- } \\
\text { ber of } \\
\text { outcrop } \\
\text { samples }\end{array}$ & Mean & $\begin{array}{c}\text { Num- } \\
\text { ber of } \\
\text { core } \\
\text { samples }\end{array}$ & Mean \\
\hline $\begin{array}{l}\mathrm{U} \\
\mathrm{V} \\
\mathrm{CaCO}\end{array}$ & $\begin{array}{r}20 \\
20 \\
20 \\
4\end{array}$ & $\begin{array}{r}11 \\
460 \\
\sim 15 \\
94,000\end{array}$ & $\begin{array}{l}67 \\
67 \\
67 \\
18\end{array}$ & $\begin{array}{r}15 \\
\sim 610 \\
<14 \\
67,000\end{array}$ & $\begin{array}{l}7 \\
7 \\
7\end{array}$ & $\begin{array}{r}197 \\
1,742 \\
90\end{array}$ & $\begin{array}{r}160 \\
160 \\
160 \\
58\end{array}$ & $\begin{array}{r}182 \\
1,260 \\
49 \\
46,000\end{array}$ & $\begin{array}{l}19 \\
19 \\
19 \\
12\end{array}$ & $\begin{array}{r}3,230 \\
14,400 \\
226 \\
26,000\end{array}$ & $\begin{array}{l}39 \\
39 \\
39 \\
37\end{array}$ & $\begin{array}{r}3,900 \\
7,100 \\
172 \\
39,800\end{array}$ \\
\hline
\end{tabular}

A part of the vanadium is presumably held in the clays. According to Foster $(1959$, p. 131), the vanadium, as an octahedral cation, has replaced the aluminum ion, thus causing an increased replacement of silica by aluminum in interlayered montmorillonite. The result is a reduction of both aluminum and silica and an increase in vanadium in the clays.

Uravan mineral belt samples have been similarly treated and tabulated in table 8 for comparison with those from the Yellow Cat area. The ore samples contain more uranium and vanadium than those ores collected in the Yellow Cat area, and the abundance ratios 
TABLE 8.-Metal content, in parts per million, of sandstones in drill cores from the Uravan mineral belt [Samples were taken from holes 35 and 38 in the Ellison group; 163, 166, and Maverick 711 and 728 on Calamity Mesa; and 97, 101, 322 , and 329 on Club Mesa in Montrose County' Colo. Analysts: P. R. Barnett, A. T. Myers, J. N. Rosholt, R. G. Havens, and C. H. Huffman, Jr.]

\begin{tabular}{|c|c|c|c|c|c|c|c|c|c|c|}
\hline \multirow{2}{*}{ Element } & \multicolumn{3}{|c|}{$\begin{array}{l}\text { Unmineralized sandstone }(<40 \mathrm{U} \text { or } \\
\left.<50 \mathrm{U}_{3} \mathrm{O}_{8}\right)\end{array}$} & \multicolumn{3}{|c|}{$\begin{array}{l}\text { Mineralized sandstone }(40-840 \mathrm{U} \text { or } 50- \\
\left.\qquad, 000 \mathrm{U}_{3} \mathrm{O}_{8}\right)\end{array}$} & \multicolumn{3}{|c|}{$\begin{array}{c}\text { Ore sandstone }(>840 \mathrm{U} \text { or }>5,600 \mathrm{v} ; \\
\left.>1,000 \mathrm{U}_{3} \mathrm{O}_{8} \text { or }>10,000 \mathrm{~V}_{2} \mathrm{O}_{5}\right)\end{array}$} & \multirow{2}{*}{$\begin{array}{l}\text { Abundance } \\
\text { ratio } \\
\text { ore/barren }\end{array}$} \\
\hline & $\begin{array}{c}\text { Number of } \\
\text { samples }\end{array}$ & Range & Mean & $\begin{array}{c}\text { Number of } \\
\text { samples }\end{array}$ & Range & Mean & $\begin{array}{c}\text { Number of } \\
\text { samples }\end{array}$ & Range & Mean & \\
\hline 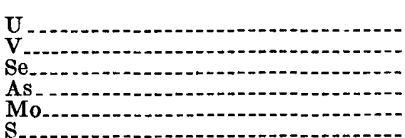 & \multirow{5}{*}{$\begin{array}{c}12 \\
12 \\
12 \\
5 \\
12 \\
0 \\
12 \\
12 \\
12 \\
12 \\
5 \\
12 \\
12 \\
12 \\
12\end{array}$} & $\begin{array}{rr}2.8- & 40 \\
200- & 1,600 \\
<.7- & 12 \\
10- & 30 \\
<3- & 130\end{array}$ & $\begin{array}{c}11.5 \\
400 \\
<2.3 \\
18 \\
\approx 26\end{array}$ & \multirow{5}{*}{$\begin{array}{l}9 \\
9 \\
9 \\
1 \\
9 \\
2 \\
9 \\
9 \\
9 \\
9 \\
1 \\
9 \\
9 \\
9 \\
9\end{array}$} & \multirow{5}{*}{$\begin{array}{rr}50- & 600 \\
200- & 4500 \\
<1- & 276 \\
- & 100 \\
5- & 600 \\
- & 200 \\
6- & 50 \\
9- & 40 \\
2- & 100 \\
2- & 70 \\
2-22,000 \\
<1- & 9 \\
10- & 30 \\
100- & 600 \\
<50- & 200\end{array}$} & \multirow{5}{*}{$\begin{array}{r}164 \\
1,500 \\
\approx 44 \\
100 \\
164 \\
200 \\
15 \\
29 \\
23 \\
28 \\
22,000 \\
<3 \\
24 \\
320 \\
\approx 87\end{array}$} & \multirow{5}{*}{$\begin{array}{l}\mathbf{3} \\
\mathbf{3} \\
\mathbf{3} \\
\mathbf{2} \\
\mathbf{3} \\
\mathbf{3} \\
\mathbf{3} \\
\mathbf{3} \\
\mathbf{3} \\
\mathbf{3} \\
\mathbf{2} \\
\mathbf{3} \\
\mathbf{3} \\
\mathbf{3} \\
\mathbf{3}\end{array}$} & \multirow{5}{*}{$\begin{array}{rr}2,600-25, & 300 \\
6,700-35, & 800 \\
38- & 224 \\
50- & 500 \\
<3- & 600 \\
300-15, & 800 \\
8- & 80 \\
10- & 40 \\
10- & 500 \\
7- & 70 \\
8,000-28, & 000 \\
<1- & 5 \\
20- & 30 \\
80- & 500 \\
50- & 300\end{array}$} & \multirow{5}{*}{$\begin{array}{r}10,400 \\
16,900 \\
1100 \\
275 \\
\approx 200 \\
5,600 \\
36 \\
23 \\
170 \\
32 \\
18,000 \\
<2 \\
26 \\
260 \\
180\end{array}$} & $\begin{array}{c}904 \\
42 \\
>43.4 \\
15.2 \\
\approx 7.6 \\
-. .9\end{array}$ \\
\hline Ni & & $\begin{array}{r}<5- \\
8-\quad 20\end{array}$ & 16 & & & & & & & $\begin{array}{r}>6.5 \\
1.4\end{array}$ \\
\hline $\begin{array}{l}\mathrm{Pb}-\mathrm{Cu} \\
\mathrm{Cu}-\mathrm{A}\end{array}$ & & $\begin{array}{cr}<1- & 20 \\
3- & 40 \\
5,000-20,000\end{array}$ & $\begin{array}{r}4 \\
16 \\
14,000\end{array}$ & & & & & & & $\begin{array}{l}>42 \\
21.2\end{array}$ \\
\hline A & & $\begin{array}{c}0, \\
<1- \\
7-\end{array}$ & $<1$ & & & & & & & $\begin{array}{l}2 \\
2\end{array}$ \\
\hline Mn & & $\begin{array}{lr}200- & 900 \\
<50- & 80\end{array}$ & $\begin{array}{l}400 \\
<56\end{array}$ & & & & & & & $>3.25$ \\
\hline
\end{tabular}


are likewise increased for most metals. The Yellow Cat ores, however, contain more selenium, arsenic, cobalt, nickel, iron, silver, and zinc. The lead that occurs in the ore bodies is largely radiogenic, and the uranium: lead ratio in each set of samples is about the same. The selenium content of the Thompson ores is about twice that of the Uravan mineral belt ores. L. B. Riley (written communication, 1954) studied 885 samples from the Colorado Plateau and found the greatest amounts of selenium in samples from Temple Mountain in the San Rafael Swell and from the Henry Mountains (as much as $300 \mathrm{ppm}$ ), intermediate amounts in samples from the Thompson and Green River districts, and the smallest amounts in samples from the Uravan mineral belt.

The abundance ratios of the two suites of samples are compared in table 9 with those obtained by Shoemaker and others (1956, p. 23).

TABLE 9.-Relative abundance ratios of elements in three collections of Colorado Plateau uranium ores from the Morrison Formation

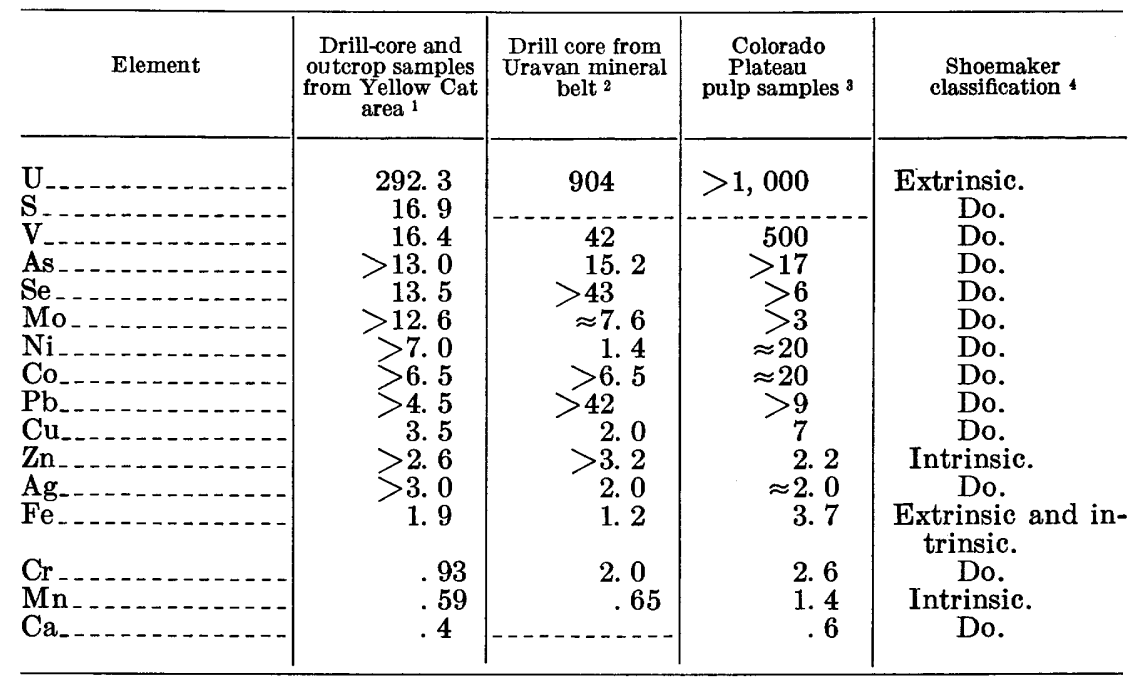

1 Uranium, vanadium, selenium, and calcium ratios calculated from arithmetic means of 39 ore and 67 barren drill-core samples and 19 ore and 20 barren outcrop samples; other elements calculated from about 22 ore and 20 barren outcrop samples.

2 Ratios calculated from 3 ore and 12 barren drill-core samples from above, below, and along strike from ore.

3 Ratios calculated from geometric means of 96 unmineralized outcrop samples and 211 pulp samples (Shoemaker and others, 1956, p. 13).

${ }_{4}$ Classification used by Shoemaker and others $(1956$, p. 23).

As the unmineralized sandstone samples were collected from within 500 feet of the ore in both the Yellow Cat area and the Uravan mineral belt, the abundance ratios for major ore constituents are less than those calculated by Shoemaker for the Colorado Plateau. Ratios for selenium, lead, and molybdenum are exceptions. An abundance ratio for manganese and calcium of less than 1 was obtained in samples from the Yellow Cat ore. (See table 5.) Shoemaker and others (1959, 
p. 44-45) showed that manganese has a close correlation with calcium in both mineralized and unmineralized sandstones and probably occurs in calcite as rhodochrosite. They also attributed the deficiency of calcium in the ore to a "*** selective mineralization of sandstone with low carbonate cement content $* * *$ " and suggested " *** that the calcite may have been leached from the ore deposits during oxidation, due to low $\mathrm{pH}$ conditions produced by alteration of sulfides."

The concentration of selenium in the ore bodies was found to parallel that of uranium and vanadium. Data for samples collected in and around the ore bodies are given in table 10 .

TABLE 10.-Average uranium, vanadium, and selenium contents, in parts per million, of 11 ore bodies and surrounding rocks compared with contents in sandstone of the Salt Wash Member

\begin{tabular}{|c|c|c|c|c|}
\hline & & Vanadium & Uranium & Selenium \\
\hline 1 & Sandstone above the ore & 2,300 & 120 & 48 \\
\hline 2 & Ore $\ldots$ & 36,400 & 7,670 & 280 \\
\hline 3 & Sandstone below the ore & 1,600 & 325 & 49 \\
\hline 4 & First inch of altered mudstone & & & \\
\hline 5 & $\begin{array}{l}\text { below sandstone } 3 \\
\text { Sandstone along the strike } 500\end{array}$ & 3,900 & 400 & 33 \\
\hline & ft from ore & 3,000 & 190 & 31 \\
\hline 6 & $\begin{array}{l}\text { First inch of altered mudstone } \\
\text { below sandstone } 5\end{array}$ & 400 & 30 & 29 \\
\hline 7 & $\begin{array}{l}\text { Average barren sandstone in } \\
\text { the Salt Wash on Colorado } \\
\text { Plateau (from table } 3 \text { ) }\end{array}$ & 18 & 1 & $\approx .5$ \\
\hline
\end{tabular}

The data suggest a close association of selenium with uranium and vanadium and suggest a geochemical halo of all three elements surrounding the ore. Vanadium is especially abundant in the first inch of altered mudstone under the ore-bearing sandstone.

Elston and Botinelly (1959, p. 211) found that diffuse bands of native selenium surround corvusite pods which are imbedded in carnotite ore. Roach and Thompson $(1959$, p. 201) showed that native selenium in the Peanut mine in the Bull Canyon district occurs along fractures in the unoxidized ore below the water table and, associated with tyuyamunite and pascoite, at the top of the unoxidized ore. Botinelly and Fischer (1959, p. 217) reported, in the predominantly vanadiferous ore at Rifle, Colo., a thin band of finely disseminated galena and clausthalite ( $\mathrm{PbSe}$ ) bordering one side of each layer of vanadium ore. Where oxidized, the band is stained with red native selenium. Similarly, in ores of the Poison Basin area, Wyoming, selenium is concentrated in a limonitic shell around central ore lenses. The concentration of selenium in the sandstone just above ore in the Parko section has already been discussed. 
D. R. Shawe (written communication, 1960) described a band surrounding a roll in the Virgin mine (Uravan district) which contains ferrosilite ( $\mathrm{FeSe}$ ), pyrite, and probably clausthalite ( $\mathrm{PbSe})$. He also reported $200 \mathrm{ppm}$ selenium in a sample collected 2 feet from unoxidized ore in the Allor 12 mine of the Yellow Cat area.

Williams and Byers (1934, p. 297) found selenium concentrated in pyrite in the Pierre Shale; as much as $205 \mathrm{ppm}$ selenium is concentrated in pyrite nodules. More recently, Weeks (1956), Coleman (1956), and Coleman and Delevaux (1957) found selenium substituted for sulfur in the crystal structure of pyrite and marcasite in many deposits of the Colorado Plateau. Coleman and Delevaux reported maximum contents of $50,000 \mathrm{ppm}$ in pyrite, $6,500 \mathrm{ppm}$ in marcasite, 180,000 $\mathrm{ppm}$ in galena-clausthalite, and $50,000 \mathrm{ppm}$ in chalcocite. They analyzed a marcasite-pyrite specimen from the Little Eva mine in the Thompson district which contained $30 \mathrm{ppm}$ selenium and a pyrite specimen from the Blackstone 6 mine in the same district which contained $81 \mathrm{ppm}$ selenium. They did not believe that, for the Colorado Plateau as a whole, a difference of $1,400 \mathrm{ppm}$ selenium in sulfides from barren Jurassic rocks compared with 2,000 ppm selenium in sulfides from mineralized rock was significant. Possibly the sampling in the Yellow Cat area was done on too large a scale. Samples collected inch by inch rather than foot by foot outward from the center of the ore into the surrounding barren sandstone might have shown a consistent banding or have indicated more precisely the exact spatial relation of the selenium to the uranium.

\section{STATISTICAL ANALYSIS}

The relation of selenium to the ore minerals was tested statistically by Gwen Luttrell. By combining analyses of suites of samples from both the Yellow Cat area and the Uravan mineral belt, correlation coefficients, defined by. Shoemaker and others $(1959$, p. 33) as a " *** measure of the geochemical coherence $* * *$ between two elements in a given type of rọck, ***" could be obtained as follows:

Statistical analyses of ore minerals

\begin{tabular}{|c|c|c|c|c|}
\hline \multirow{2}{*}{ Beds of the Salt Wash Member } & \multirow{2}{*}{$\begin{array}{l}\text { Number of } \\
\text { analyses }\end{array}$} & \multicolumn{3}{|c|}{ Correlation coefficients } \\
\hline & & $\mathrm{Se}-\mathrm{U}$ & $\mathrm{Se}-\mathrm{V}$ & $\mathrm{U}-\mathrm{V}$ \\
\hline \multirow[t]{2}{*}{ No. 1 2} & $\begin{array}{l}21 \\
47 \\
31 \\
31\end{array}$ & $\begin{array}{r}+0.64 \\
+.67 \\
+.86 \\
+.68\end{array}$ & $\begin{array}{l}+0.54 \\
+.57 \\
+.36 \\
+.75\end{array}$ & $\begin{array}{l}+0.60 \\
+.74 \\
+.58 \\
+.77\end{array}$ \\
\hline & 130 & +.71 & +.56 & +.69 \\
\hline
\end{tabular}

$721-9260-64-3$ 
A more significant correlation was obtained between selenium and uranium than between selenium and vanadium. Correlations between selenium and several other elements in 51 ore samples from the Yellow Cat area were also made, giving the following results:

Correlation of selenium with other elements

\begin{tabular}{|c|c|c|}
\hline & $\begin{array}{l}\text { Correlation } \\
\text { coefficient }\end{array}$ & Students' $t$ evaluation \\
\hline $\begin{array}{l}\text { Se-Co } \\
\text { Se-As } \\
\text { Se-Mo } \\
\text { Se-Ni } \\
\text { Se-Cr } \\
\text { Se-Fe } \\
\text { Se-Cu } \\
\text { Se-Pb } \\
\text { Se-Mn }\end{array}$ & $\begin{array}{l}+0.37 \\
+.35 \\
+.28 \\
+.27 \\
+.12 \\
+.11 \\
+.09 \\
+.015 \\
+.089\end{array}$ & $\begin{array}{l}\text { Significant. } \\
\text { Do. } \\
\text { Probably significant. } \\
\text { Do. } \\
\text { Not significant. } \\
\text { Do. } \\
\text { Do. } \\
\text { Do. } \\
\text { Do. }\end{array}$ \\
\hline
\end{tabular}

Significant correlations between selenium and cobalt and between selenium and nickel were found in Colorado Plateau ores by A. T. Miesch (written communication, 1960), but no correlation between selenium and lead, uranium, or vanadium was observed.

The following data were obtained from a few samples by using $G=$ sum of the squares of rank differences and $N=$ the number ranked. The significance of the rank correlation coefficients was tested by the student's $t$ test and was then classified as highly significant (HS), significant (S), probably significant (PS), or not significant (NS).

Correlation coefficients and classification

\begin{tabular}{|c|c|c|c|}
\hline Sample locality & $\mathrm{Se}-\mathrm{U}$ & $\mathrm{Se}-\mathrm{V}$ & U-V \\
\hline Above ore & $0.69(\mathrm{~S})$ & 0.87 (HS) & 0.81 (HS) \\
\hline In ore $\ldots .$. & .72 (S) & .67 (PS) & .79 (S) \\
\hline Below ore $\ldots$ & $.75(\mathrm{~S})$ & $.43(\mathrm{NS})$ & $.62(\mathrm{PS})$ \\
\hline Along strike & $.22(\mathrm{NS})$ & $.62(\mathrm{NS})$ & $.07(\mathrm{NS})$ \\
\hline
\end{tabular}

A definite correlation exists between selenium and uranium in the sandstone above and below, as well as in, the ore body; and a very strong correlation, which does not occur elsewhere, exists between selenium and vanadium and between uranium and vanadium in the sandstone above the ore. The meaning of this correlation is not understood unless it reflects a difference in geochemical mobility after oxidation.

The selenium-uranium analyses of suites of samples from both the Thompson district and Uravan mineral belt are plotted in figure 4. 

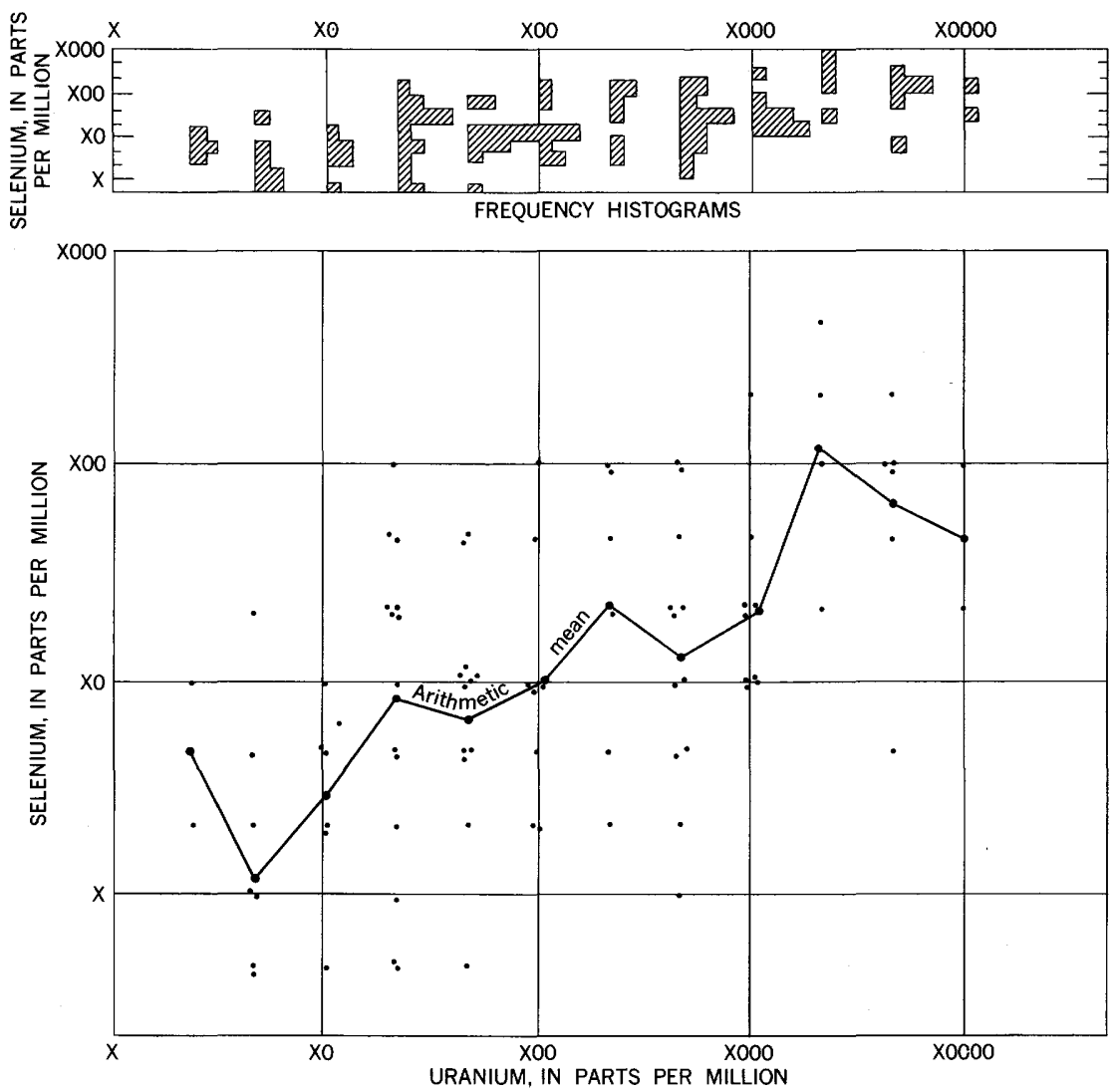

Figure 4.-Selenium-uranium ratios in samples from Thompson district and from Uravan mineral belt.

Only contents of more than $0.7 \mathrm{ppm}$ selenium were used in the calculations, for below this value the amount of selenium was not precisely measured. The random distribution of the points along any ordinate is further emphasized by the frequency histograms plotted at the top of the sheet. Probably a more consistent pattern was not obtained because the selenium is not disseminated equally throughout the ore.

Two conclusions directly applicable to prospecting in the Yellow Cat area can be drawn from the data that have been presented. First, the more than 10-fold concentration of selenium, arsenic, sulfur, and molybdenum in the ore bodies (tables 5,9 ) furnishes a geochemical target for prospecting based on the occurrence of indicator plants. Second, the unmineralized sandstone samples collected above, below, and at short distances along the strike from ore bodies contain more of the ore elements than do the unmineralized sandstone samples collected by Shoemaker and others (1956) at long distances from uranium deposits. Thus, the ore bodies are surrounded by a geo- 
chemical halo that enlarges the target and, therefore, is a useful guide in prospecting.

\section{STRATIGRAPHIC VARIATIONS IN METAL CONTENT OF THE SANDSTONES}

So that the possible variations in metal content of the 5 ore-bearing stratigraphic sandstone units could be studied, 40 samples were selected for which the content of 12 elements was known. The samples, ranging in grade from unmineralized rock to ore, were arranged in the order of the beds, 1 to 5 ; and the means werecalculated. The resulting data are shown in table 11. No definite progression of TABLE 11.-Abundance of trace metals, in parts per million, in key beds of the Salt Wash Sandstone Member in the Yellow Cat area

\begin{tabular}{|c|c|c|c|c|c|c|c|c|c|c|c|c|c|}
\hline Bed & $\begin{array}{l}\text { Number } \\
\text { of } \\
\text { samples }\end{array}$ & $\mathrm{U}$ & As & $\mathrm{Pb}$ & $\mathrm{Se}$ & Mo & V & $\mathbf{F e}$ & $\mathrm{Ni}$ & Co & $\mathrm{Cu}$ & $\mathrm{Cr}$ & $\mathrm{Mn}$ \\
\hline $\begin{array}{l}2 \\
4 \\
5\end{array}$ & $\begin{array}{r}9 \\
10 \\
6 \\
18 \\
7\end{array}$ & $\begin{array}{r}1,510 \\
550 \\
557 \\
1,983 \\
818\end{array}$ & $\begin{array}{r}200 \\
76 \\
120 \\
344 \\
173\end{array}$ & $\begin{array}{l}19 \\
16 \\
12 \\
64 \\
18\end{array}$ & $\begin{array}{r}314 \\
26 \\
55 \\
195 \\
12\end{array}$ & $\begin{array}{r}29 \\
1 \\
23 \\
111 \\
113\end{array}$ & $\begin{array}{r}8,855 \\
4,270 \\
11,700 \\
4,441 \\
5,510\end{array}$ & $\begin{array}{l}26,000 \\
16,000 \\
23,000 \\
20,000 \\
13,000\end{array}$ & $\begin{array}{l}35 \\
13 \\
31 \\
20.3 \\
22\end{array}$ & $\begin{array}{l}33 \\
34 \\
63 \\
34 \\
23\end{array}$ & $\begin{array}{r}8 \\
8 \\
27 \\
17 \\
18\end{array}$ & $\begin{array}{r}90 \\
89 \\
143 \\
74 \\
130\end{array}$ & $\begin{array}{l}400 \\
220 \\
660 \\
295 \\
290\end{array}$ \\
\hline
\end{tabular}

total metal content from top to bottom was evident from the data. Although the values are generally high for all metals in bed 1 and in the conglomerate lens at the top of the Salt Wash, the concentration does not suggest downward leaching from the montmorillonite clay in the Brushy Basin Member as a source of the uranium, nor do the clay analyses shown in table 12 indicate any such concentration.

TABLE 12.-Trace elements, in parts per million, in mudstones of the Yellow Cat area [Analysts: E. F. Cooley, E. A. Smith, H. E. Crowe, C. E. Thompson, G. T. Burrow, P. R. Barnett, A. T. Myers, Claude Huffman, Jr., R. G. Havens, R. R. Beins, S. P. Furman, R. F. Dufour, and J. W. Harbaugh]

\begin{tabular}{|c|c|c|c|c|c|c|c|c|}
\hline \multirow{2}{*}{ Element } & \multirow{2}{*}{$\begin{array}{c}\text { Average } \\
\text { abundance } \\
\text { in shales of } \\
\text { earth's crust } \\
\text { (after Ran- } \\
\text { kama and } \\
\text { Sahama } \\
\text { 1950, p. 226) }\end{array}$} & $\begin{array}{l}\text { Unminer- } \\
\text { alized } \\
\text { mudstone } \\
\text { of Uravan } \\
\text { mineral belt }\end{array}$ & \multicolumn{3}{|c|}{$\begin{array}{c}\text { Unmineralized mudstone } \\
\text { Yellow Cat area } \\
\text { (<40 U) (all exposed) }\end{array}$} & \multicolumn{3}{|c|}{$\begin{array}{l}\text { Mineralized mudstone } \\
\text { Yellow Cat area } \\
(>40 \text { U) (all exposed) } 1\end{array}$} \\
\hline & & Mean & $\begin{array}{l}\text { Num- } \\
\text { ber of } \\
\text { samples }\end{array}$ & Range & Mean & $\begin{array}{l}\text { num- } \\
\text { ber of } \\
\text { samples }\end{array}$ & Range & Mean \\
\hline $\begin{array}{l}\mathrm{U} \\
\mathrm{V} \\
\mathrm{Se} \\
\mathrm{As} \\
\mathrm{Mo} \\
\mathrm{S} \\
\mathrm{S} \\
\mathrm{Co} \\
\mathrm{Ni} \\
\mathrm{Pb} \\
\mathrm{Cu} \\
\mathrm{Fe} \\
\mathrm{Ag} \\
\mathrm{Cr} \\
\mathrm{Mn} \\
\mathrm{Zn}\end{array}$ & $\begin{array}{c}1.2 \\
\approx 5 \\
2,600 \\
8 \\
24 \\
20 \\
192 \\
47,300 \\
410-680^{\circ} \\
620 \\
200-1,000\end{array}$ & \begin{tabular}{r}
16 \\
200 \\
$\approx 6$ \\
60 \\
$\approx 1$ \\
\hdashline 7 \\
13 \\
$\approx 4$ \\
26 \\
11,000 \\
$\approx 1$ \\
40 \\
400 \\
$\approx 50$
\end{tabular} & $\begin{array}{l}34 \\
34 \\
34 \\
30 \\
34 \\
12 \\
24 \\
24 \\
24 \\
34 \\
20 \\
14 \\
29 \\
29 \\
24\end{array}$ & $\begin{array}{cr}<1.8- & 400 \\
50- & 1,600 \\
<1- & 46 \\
<10- & 200 \\
<1- & 30 \\
30- & 1,300 \\
6- & 80 \\
5- & 40 \\
<3- & 80 \\
3- & 100 \\
8,000-50,000 \\
<1- & 1 \\
20- & 120 \\
100- & 1,000 \\
<20- & 300\end{array}$ & $\begin{array}{r}\approx 12.8 \\
327 \\
\approx 9 \\
\approx 46 \\
\approx 3 \\
377 \\
16 \\
12 \\
\approx 14 \\
23 \\
21,500 \\
\approx 1 \\
54 \\
470 \\
\approx 51\end{array}$ & $\begin{array}{l}7 \\
7 \\
7 \\
7 \\
7 \\
4 \\
7 \\
7 \\
7 \\
7 \\
7 \\
7 \\
6 \\
7 \\
7 \\
6\end{array}$ & $\begin{array}{rr}120- & 1,000 \\
400- & 4,400 \\
6- & 120 \\
>100- & 400 \\
>3- & 300 \\
500-9,500 \\
10- & 30 \\
5- & 20 \\
8- & 100 \\
10- & 30 \\
15,000-33,000 \\
>1- & 40 \\
50-2,000 \\
100-2,000 \\
>50-1,600\end{array}$ & $\begin{array}{r}360 \\
1,410 \\
57 \\
\approx 210 \\
\approx 70 \\
2,800 \\
16 \\
14 \\
28 \\
24 \\
20,100 \\
\approx 8 \\
520 \\
530 \\
\approx 350\end{array}$ \\
\hline
\end{tabular}

1 Six samples collected from first inch of mudstone underlying ore-bearing sandstone. 
Two significant geochemical associations of elements are apparent from figures 5 and 6 . Uranium, arsenic, selenium, lead, and molybdenum are similarly abundant in bed 4 whereas vanadium, iron, nickel, cobalt, chromium, manganese, and copper show a pronounced concentration in bed 3 . This difference in concentration might reflect a difference in origin, as tuffaceous material is more concentrated in bed 4 and heavy metals are more concentrated in bed 3; or, assuming that a similar assemblage of metals existed in the two beds originally, the difference could be a result of weathering phenomena. In the area of capillary movement of ground water, possibly the uranium has been preferentially freed from the iron hydroxides or carnotite and has combined with carbonate to form soluble compounds that have migrated along with selenium and molybdenum into the overlying clays, leaving an apparent deficiency in bed 3 as compared with the elements that have remained firmly fixed.

\section{DISTRIBUTION OF METALS IN THE MUDSTONES}

Because the mudstones in the Morrison Formation are a possible source of the metals in the ore, the chemistry of these beds should be considered.

Analyses of about 40 mudstone samples collected during the course of the study are presented in table 12 . Six of the seven mudstone samples classified as mineralized (containing $>40 \mathrm{ppm}$ uranium) were collected from the first inch directly below ore-bearing sandstone and represent an enrichment by downward leaching; the seventh was collected from within an ore body. The mudstone samples classified as unmineralized contain more uranium, vanadium, selenium, and arsenic but less in sulfur, nickel, lead, copper, iron, chromium, manganese, and zinc than does an average shale.

Mudstone samples were later collected from known stratigraphic zones through unmineralized parts of the Salt Wash and the Brushy Basin Members. The samples were tested using the benzidene test for montmorillonite as described by Waters and Granger (1953) and were analyzed for selected elements. The results, arranged in the descending stratigraphic order of units sampled, are shown in table 13.

Neither the red nor the green mudstones of the Brushy Basin Member contain unusually large quantities of metals. The most metal-bearing samples were collected in the Salt Wash Member from the mudstones between beds 2 and 3 . Red unaltered mudstone collected from this stratum contains unusually large quantities of nine elements-vanadium, uranium, selenium, arsenic, lead, iron, and also chromium, copper, and nickel. Green mudstone from the same layer contains less of these metals.

Keller (1959) showed that the red and green mudstones do not differ in clay mineralogy. Garrels and.Larsen (1959, p. 234) summarized 


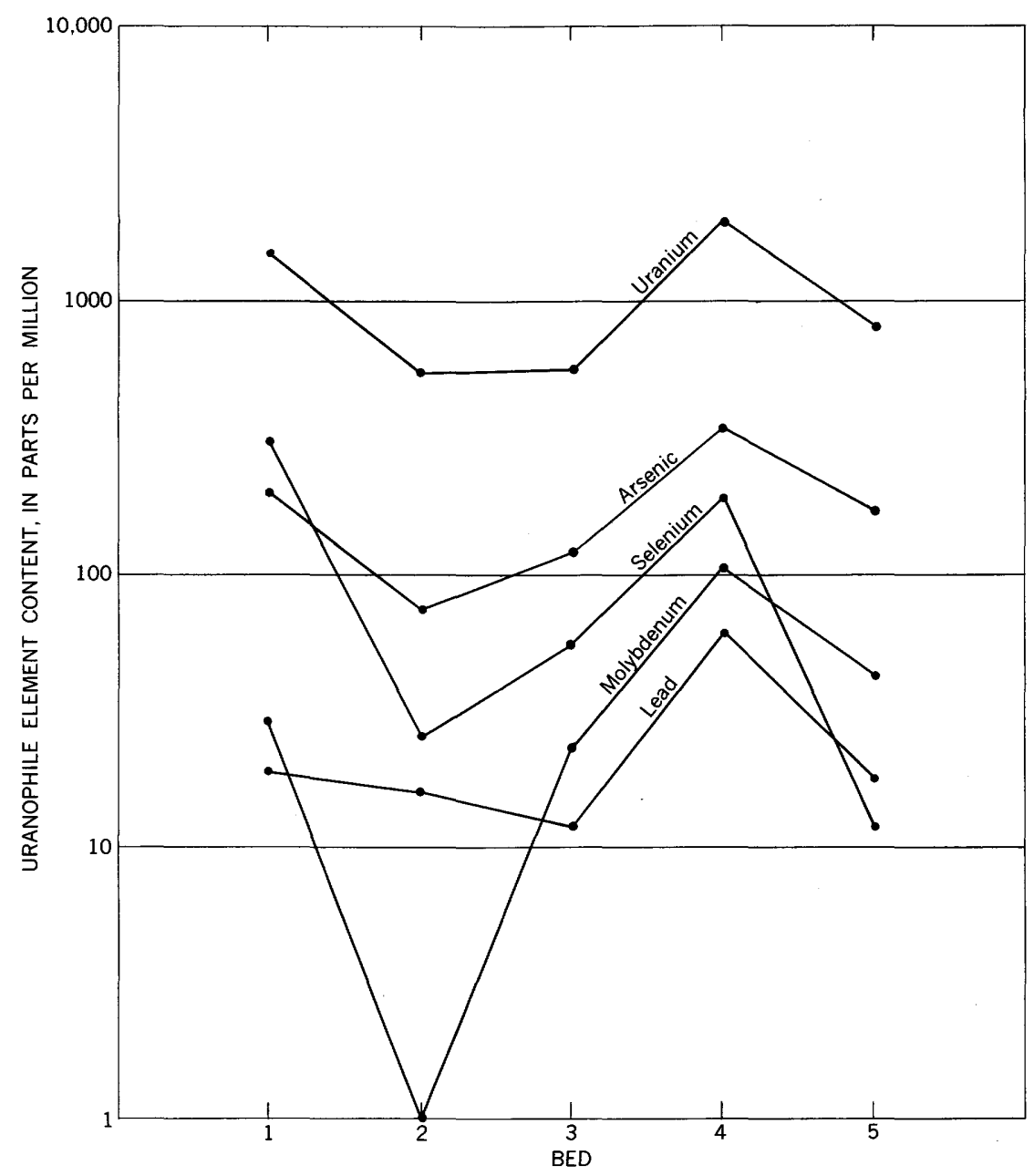

FIGURE 5.-Abundance of 5 uranophile elements in 40 samples grouped according to key bed within the Salt Wash Member of the Morrison Formation.

the differences as a decrease in the ferric-ferrous ratio in the green clays and a loss of the minerals calcite and hematite, although the average metal contents of the unaltered mudstones are higher than those of the green altered mudstones for all elements except copper and manganese. A similar increase in vanadium content in red mudstones was found by L. C. Huff and D. R. Shawe (written communication, 1954).

The apparent depletion of metals in altered mudstone near ore compared with the apparent depletion of metals in unaltered mudstone at the same stratigraphic level away from ore suggests that the 


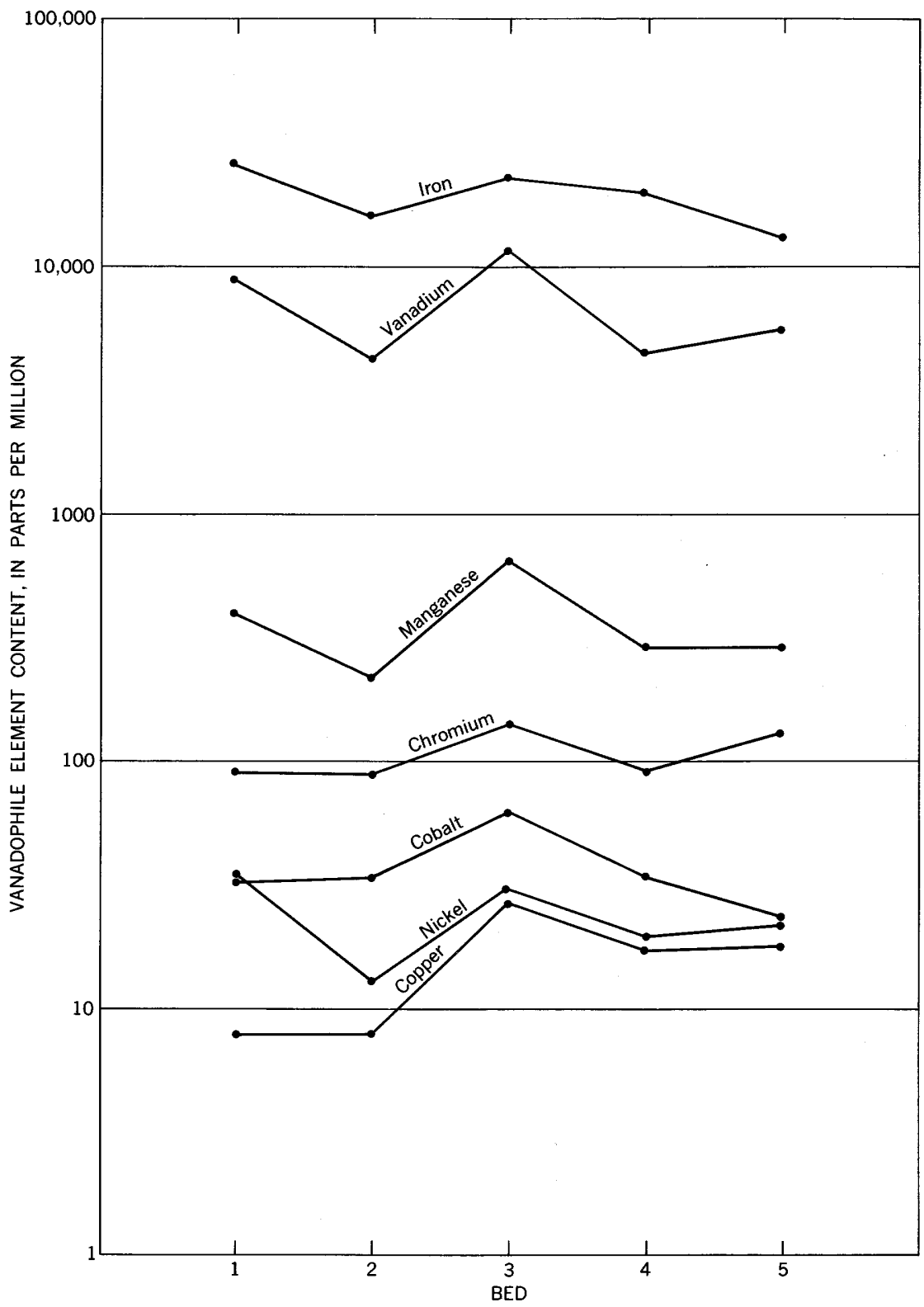

Figure 6.-Abundance of 7 vanadophile elements in 40 samples grouped according to key bed within the Salt Wash Member of the Morrison Formation.

metals may have been introduced into the clays originally as volcanic ash and later, during devitrification of the ash, may have been moved into the nearest sandstone of high permeability. In other words, the metal content of the altered mudstones interbedded with 
TABLE 13.-Distribution of metals in mudstones throughout the Morrison Formation

[Data are in parts per million except as indicated. Zine content of all samples 20 ppm; molybdenum and cobalt contents 10 ppm. Analysts: G.T. Burrow, E. F. Cooley, and

\begin{tabular}{|c|c|c|c|c|c|c|c|c|c|c|c|c|c|}
\hline Sample & Description & U & $\mathbf{v}$ & As & $\mathrm{Se}$ & $\mathrm{s}$ & $\mathbf{P b}$ & $\mathrm{Cu}$ & $\mathrm{Ni}$ & $\mathrm{Cr}$ & $\underset{\text { (percent) }}{\mathrm{Fe}}$ & $\underset{\text { (percent) }}{\mathrm{Mn}}$ & Montmorillonite test \\
\hline \multirow{2}{*}{$\begin{array}{r}\text { GX-58-864_... } \\
865 \\
866 \\
867 \\
\end{array}$} & $\begin{array}{l}\text { Red, unaltered; Brushy Basin } \\
\text { Green, altered; Brushy Basin }\end{array}$ & \multirow{2}{*}{$\begin{array}{r}<4 \\
4 \\
<4 \\
12\end{array}$} & \multirow{2}{*}{$\begin{array}{r}50 \\
150 \\
100 \\
100\end{array}$} & \multirow{2}{*}{$\begin{array}{r}<10 \\
<10 \\
<10 \\
20\end{array}$} & \multirow{2}{*}{$\begin{array}{r}20 \\
12 \\
30 \\
2\end{array}$} & \multirow{2}{*}{$\begin{array}{l}<300 \\
<300 \\
<300 \\
<300\end{array}$} & \multirow{2}{*}{$\begin{array}{l}10 \\
30 \\
15 \\
10\end{array}$} & \multirow{2}{*}{$\begin{array}{l}20 \\
30 \\
30 \\
30\end{array}$} & \multirow{2}{*}{$\begin{array}{l}5 \\
5 \\
7 \\
7\end{array}$} & \multirow{2}{*}{$\begin{array}{l}30 \\
20 \\
50 \\
50\end{array}$} & \multirow{2}{*}{$\begin{array}{l}3.0 \\
3.0 \\
3.0 \\
2.0\end{array}$} & \multirow{2}{*}{$\begin{array}{l}0.015 \\
.01 \\
.02 \\
.02\end{array}$} & \multirow{2}{*}{$\begin{array}{l}\text { Negative. } \\
\text { Do.. } \\
\text { Positive. } \\
\text { Negative. }\end{array}$} \\
\hline & Green altered; under brown conglomerate & & & & & & & & & & & & \\
\hline $868 \ldots$ & Silt, contains green clay cement; under & $<4$ & 50 & $<10$ & 30 & $<300$ & 10 & 20 & 5 & 30 & 1.0 & .07 & Positive. \\
\hline $879 \ldots$ & Same as sample 868 except contains red & 8 & 300 & 30 & 20 & 500 & 70 & 50 & 10 & 70 & 5.0 & .02 & $\begin{array}{l}\text { Red clay containing small specks } \\
\text { of green montmorillonite. }\end{array}$ \\
\hline $869 \ldots$ & $\begin{array}{l}\text { Silt; under bed } 3 \\
\text { Same, green clav; under bed } 3\end{array}$ & $\begin{array}{r}4 \\
<4\end{array}$ & $\begin{array}{l}70 \\
70\end{array}$ & $<10$ & $<2$ & $\begin{array}{l}<300 \\
1,300\end{array}$ & $<10$ & $\begin{array}{r}100 \\
30\end{array}$ & $\begin{array}{l}5 \\
5\end{array}$ & $\begin{array}{l}50 \\
30\end{array}$ & $\begin{array}{l}1.5 \\
2.0\end{array}$ & .02 & $\begin{array}{l}\text { Positive. } \\
\text { Do. }\end{array}$ \\
\hline $\begin{array}{ll}871 \ldots \\
872 \ldots-\end{array}$ & $\begin{array}{l}\text { Mottled red and green, under bed 4.... } \\
\text { Mottled red and green; under bed } 5 . . .\end{array}$ & $\begin{array}{l}\sum_{4}^{4} \\
<4\end{array}$ & $\begin{array}{r}100 \\
100 \\
70\end{array}$ & $\begin{array}{r}10 \\
<10\end{array}$ & $\begin{array}{l}30 \\
20\end{array}$ & $\stackrel{1}{<300}<300$ & $\begin{array}{r}10 \\
<10\end{array}$ & $\begin{array}{l}50 \\
20 \\
50\end{array}$ & $\begin{array}{l}0 \\
7 \\
5\end{array}$ & $\begin{array}{l}50 \\
70 \\
50\end{array}$ & $\begin{array}{l}2.0 \\
1.0\end{array}$ & .07 & $\begin{array}{l}\text { Negative. } \\
\text { A few small specks of montmoril- } \\
\text { lonite. }\end{array}$ \\
\hline & $\begin{array}{l}\text { verage for red clay } \\
\text { iverage for green clay..... }\end{array}$ & $\begin{array}{r}6 \\
<5\end{array}$ & $\begin{array}{r}170 \\
90\end{array}$ & $\stackrel{\sim}{20}$ & $\begin{aligned} 20 \\
<13\end{aligned}$ & $<400$ & $\begin{array}{r}40 \\
<14\end{array}$ & $\begin{array}{l}35 \\
40\end{array}$ & $\begin{array}{l}7 \\
5\end{array}$ & $\begin{array}{l}50 \\
40\end{array}$ & $\begin{array}{l}4.0 \\
2.0\end{array}$ & .017 & \\
\hline
\end{tabular}


the sandstones and the interstitial clay may have been considerably greater at one time than it is today.

The concentrations of uranium, selenium, vanadium, sulfur, and molybdenum in the ore bodies; the presence of a geochemical halo in the unmineralized sandstones surrounding the ore bodies; and the deficiency of metals in the mudstones surrounding the ore bodies are major considerations in prospecting. By using the geochemical background that has been presented for the rocks of the Yellow Cat area, prospecting by both plant analysis and plant indicators can be interpreted and evaluated. The information gathered for this purpose may also have a bearing on the origin of the deposits.

\section{SOURCE OF THE METALLIC ELEMENTS}

Many theories on the origin of the uranium-vanadium deposits of the Colorado Plateau have been proposed, but the significance of the association of selenium with uranium has until recently been largely overlooked. Selenium and uranium are precipitated simultaneously under certain chemical conditions of deposition and, therefore, occur together in specific types of deposits. The association is most common in hydrothermal deposits, in clay-sand sediments where the metals are adsorbed on hydroxide gels of iron and manganese, in volcanic-ash beds, and in carbonaceous shales and coals where the metals are reduced by the action of humus on circulating ground waters.

In the Yellow Cat area, neither the distribution of elements through the stratigraphic column nor the distribution along the strike of the beds suggests the presence of a deep-seated source for the metals concentrated in the ores. Rather, the distribution of elements indicates a widespread dissemination of metallic elements throughout the beds in which the deposits are now located or in source beds near the ores. Although uranium, vanadium, and selenium have undoutedly been precipitated on hydroxide gels of iron and by the reducing action of humus and buried wood fragments within the channelways, concentrations of the magnitude previously shown suggest an outside source of metals. The concentrations of uranium and vanadium are very large; that of selenium, although only 13 times that of the enclosing sandstone, is extremely high compared with the concentration in normal sandstones. The ratios of selenium to sulfur of 1:23 in the mudstones and 1:27 in the sandstones are at least 150 times greater than any ratios presented by Goldschmidt (1954, p. 532) for ordinary sediments or for hydrothermal vein deposits.

The suite of elements that is found to be most strongly enriched in the ores of the Yellow Cat area comprises uranium, vanadium, arsenic, selenium, molybdenum, cobalt, iron, and nickel. A. T. Miesch 
(written communication, 1962) found that this group of minerals, along with recognizable tuffaceous materials, increases in abundance toward the northwestern part of the Colorado Plateau. Waters and Granger (1953), Keller (1956), and Garrels (1957) suggested volcanic ash as a source of the uranium on the Colorado Plateau. The uraniumselenium relationship in the Yellow Cat area does not refute this theory and may even support it.

\section{PRESENT-DAY WEATHERING OF ORE MINERALS AS RE- LATED TO PROSPECTING}

As ores that occur in the zone of aeration above the water table become oxidized, they act as reservoirs from which ions are released to surface waters, soils, and plants. Anomalous amounts of these metals can be detected and are useful in prospecting.

Uranium is dispersed slowly in the presence of vanadium, arsenic, or phosphate and forms insoluble compounds with these elements (Garrels and Christ, 1959). In the absence of these elements or in the presence of excessive calcium carbonate, uranium combines with carbonate and sulfate anions to form soluble and mobile compounds. In the Thompson district, both calcium carbonate minerals and pyrite are abundant; so the uranyl ions become complexed as uranyl carbonate and uranyl sulfate. These hexavalent uranium ions have a high degree of geochemical mobility and are carried in the ground and surface waters. Many of the mine dumps in the district are covered with selenite $\left(\mathrm{CaSO}_{4} \cdot 2 \mathrm{H}_{2} \mathrm{O}\right)$ crystals. Opencut exposures such as at the Cactus Rat mine are coated with hydrated brightly colored fluorescent uranium salts; the increasing abundance of these soluble salts from the surface downward through 25 feet of beds led to the discovery of the Little Eva mine in Pittsburg Park. During transit these uranium compounds may become adsorbed on hydroxide gels of iron, aluminum, and manganese or on silica gel (Rankama and Sahama, 1950, p. 632).

Under arid conditions such as those that exist in the Yellow Cat area, vanadium is probably concentrated in aluminum hydroxide released by the decomposition of clay minerals (Rankama and Sahama, 1950 , p. 599) and as $\mathrm{V}_{2} \mathrm{~S}_{5}$ in asphaltic and bituminous matter.

Selenium, during the breakdown of the ore minerals, probably alters to selenite ions that may combine with iron, copper, cobalt, or molybdenum (Rankama and Sahama, 1950, p. 953). Little is actually known about the forms of selenium in the soils that produce toxic vegetation. Trelease and Beath (1949, p. 106) found that more than half of several thousand soil samples tested contained less than $2 \mathrm{ppm}$ selenium; the maximum content was $100 \mathrm{ppm}$ selenium. Most of this selenium probably occurs as ferric selenite $\left[\mathrm{Fe}_{2}(\mathrm{OH})_{4} \mathrm{SeO}_{3}\right]$ and is un- 
available to plants, but 95 percent of it could be freed by treating the soils with sulfuric acid. Trelease and Beath stated that elemental selenium may be present in exceedingly small amounts in some soils, as certain bacteria, fungi, and algae are capable of reducing selenites, and probably selenates, to the elemental form.

In most soils, the water-soluble content of selenium is $<0.1 \mathrm{ppm}$ (Trelease and Beath, 1949, p. 107). Available selenium occurs in the soil in organic compounds and as the selenate ion. Organic selenium compounds are released through the decay of plants; the inorganic fraction probably is mostly calcium selenate. The soluble compounds are mostly leached out of the surface soil in humid climates; but in arid climates, such as that of the Thompson district, they become enriched in the surface soil through the seasonal decay of seleniferous vegetation and by evaporation of the soil water that has moved upward by capillarity (Trelease and Beath, 1949, p. 105). This enrichment can be seen in the analyses of the Parko 23-2 openpit (table 4). If the surface selenium at the Parko $23-2$ is mostly water soluble, the amount is ample to support a colony of Astragalus pattersoni. In experimental plot studies in connection with this research, this species was able to extract $11,680 \mathrm{ppm}$ selenium (in the ash) from soil containing $<2 \mathrm{ppm}$ water-soluble selenium.

The effect of $\mathrm{pH}$ on the availability of molybdenum to plants is related to the adsorption of molybdenum, probably as the molybdate ion, on ferric oxides. Ferric oxide will remove from solution 98-100 percent of the molybdenum at $\mathrm{pH}$ values of 7.0 or less (Jones, 1956). But in alkaline soils, molybdenum minerals react readily during weathering to form the soluble oxide molybdite $\left[\mathrm{MoO}_{3}\right]$, hydrated oxides $\left[\mathrm{FeO} \cdot 3 \mathrm{MoO}_{3} \cdot 8 \mathrm{H}_{2} \mathrm{O}\right]$, and ilsemannite $\left[\mathrm{Mo}_{3} \mathrm{O}_{8} \cdot n \mathrm{H}_{2} \mathrm{O} \pm \mathrm{H}_{2} \mathrm{SO}_{4}\right]$ (Rankama and Sahama, 1950, p. 628). Ilsemannite is formed where ferrous iron is scarce. If ground waters that carry alkali molybdates come in contact with high calcium concentrations, the insoluble calcium salts of molybdic acid will be precipitated. Ilsemannite has been noted around carnotite deposits of the Colorado Plateau, but in the Yellow Cat area where calcium is especially abundant and much iron is present, the molybdenum is probably complexed with calcium and iron in the soil.

Knowledge of the decay of radioactive materials during weathering is significant to our problem because such knowledge can be applied in prospecting and also because the members of the decay series may affect the availability of other elements in the ore environment. Leaching of the ores by either acid or carbonate solutions splits the uranium decay series so that uranium, protactinium, and thorium dissolve and all daughter products lighter than thorium remain in place (R. S. Cannon, written communication, 1951). It has al- 
ready been shown (p. 2) that uranium-particularly water-soluble uranium-migrates outward from the Colorado Plateau carnotite deposits, but studies of gamma-ray logs have shown that the radioactive decay products do not migrate. Bell and Rogers (1950) stated that ore cannot be detected by its radioactivity through more than 3 feet of rock. A radioactivity anomaly (similar to the chemical anomaly in the first inch of underlying mudstone reported on page 26) occurs at the contact of the ore-bearing sandstone and underlying clay. The anomaly extends 200 feet laterally from the ore wherever the contact, within the ore body, is separated from ore by no more than 3-6 feet of barren sandstone. Anomalies extend downdip from ore and may be due to ground-water leaching of radioactive ore constituents. In general, mudstone is more radioactive than sandstone. Hoogteÿling and Sizoo (1948) tested a series of clays for radioactivity and found no relation between radioactivity and the type of clay minerals; however, they did find that radioactivity increased as the grain size of the clay decreased. They concluded that during chemical transformation of the original minerals into clay, the radioactive elements are adsorbed on the surface of the precipitating particles.

Field studies in New Mexico by R. S. Cannon, H. L. Cannon, and R. L. Smith, showed that Miocene deposits in the Cuyamungue area had such a history of weathering. Here, part of the uranium that was set free during the oxidation of sulfides enclosed in volcanic tuffs combined with what vanadium was available to form carnotite; the remaining uranium was leached downward to enrich the underlying clays. The less mobile radioactive decay products and selenium also remained behind; as a result only the carnotite is in equilibrium, the iron gossan is deficient in uranium, and the clays are enriched in uranium.

\section{GEOCHEMICAL PROSPECTING IN THE Yellow CAT AREA}

\section{PROSPECTING BY WATER ANALYSIS}

Prospecting by the analysis of both ground and surface water has been used successfully in many countries to define areas of anomalous metal content. Ostler (1954) reported using, since 1949, analyses of surface waters as a method of prospecting for uranium deposits in southwest England. His analyses were made by a colorimetric method using ion exchange resins. He found that the uranium contents were influenced by the season of the year in which the samples were collected; by the $\mathrm{pH}$, oxygen content, clay and colloid content of the water; and by the chemistry of the deposits. The highest values were obtained after heavy rains. Anomalous values were detected 6 miles downstream from the deposits. Uranium in waters 
in Russia was investigated by Saukoff (1956). Analyses of the uranium content of streams have led to the discovery of a major ore deposit in southern France (Arnold Grimbert, oral communication, 1960) by the French Atomic Energy Commission.

Water analysis by fluorimetric methods was used by Denson, Zeller, and Stephens (1955) throughout the Western United States to determine those areas where uranium is likely to occur in beds overlain by volcanic units. Many anomalies in water contents have subsequently been found to indicate commercial deposits of uranium. A field method for determining uranium in natural waters by using ion-exchange resins was described by Ward and Marranzino (1957) and was used by Fix $(1954 ; 1955)$ of the U.S. Geological Survey in a study of uranium in natural waters in the Western United States. In unmineralized areas of the Colorado Plateau, Fix found that surface waters contained from 0.5 to $3.0 \mathrm{ppb}$ (parts per billion) uranium and that the ground water contained from 1 to $10 \mathrm{ppb}$ uranium., In mineralized areas of the plateau, he found that surface waters contained from 3 to $10 \mathrm{ppb}$ uranium and that the ground water contained from 5 to several hundred parts per billion uranium. Phoenix (1959) collected 24 water samples (mostly from springs) from the Colorado Plateau and found a maximum of $0.82 \mathrm{ppm}$ uranium and $11.8 \mathrm{ppm}$ vanadium in one sample (table 14 ).

The streambeds of the Yellow Cat area are completely dry except in flood time, and there are no water wells in the area. Year-round

TABLE 14.-Analyses, in parts per million, of mineralized waters from Yellow Cat area

[Manganese and copper looked for but not found. Analysts: G. J. Petretic, L. F. Rader, Jr., and C. S. Howard. Samples collected by D. A. Phoenix $(1959$, p. 60)]

\begin{tabular}{|c|c|c|}
\hline Element & $\begin{array}{c}\text { Cactus Rat spring } \\
6 / 29 / 50\end{array}$ & $\begin{array}{l}\text { Yellow Cat Camp- } \\
\text { site spring } 6 / 29 / 50\end{array}$ \\
\hline 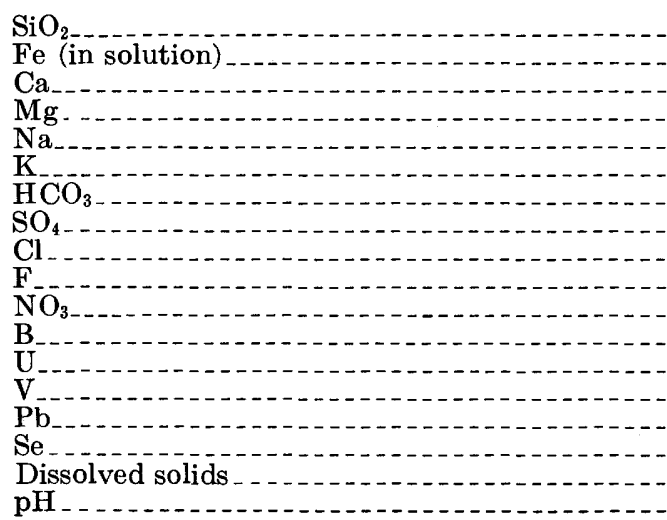 & $\begin{array}{l}10 \\
101.03 \\
15 \\
343 \\
3.4 \\
205 \\
806 \\
47 \\
.3 \\
5.8 \\
.02 \\
.2 \\
.1 \\
.02 \\
7.87 \\
1,430 \\
7.9\end{array}$ & $\begin{array}{c}11 \\
89 \\
89 \\
20 \\
129 \\
6.1 \\
202 \\
388 \\
13 \\
.4 \\
2.6 \\
.04 \\
.8 \\
.1 \\
.04 \\
1.0 \\
759 \\
7.9\end{array}$ \\
\hline
\end{tabular}


water supply is restricted to a few springs, all of which drain uranium mines that have been in existence for many years. Complete analyses of the only two spring-water samples available to Phoenix are given in table 14. Seven years after Phoenix made his collection, I collected samples from these two springs and from a seep; the samples were analyzed for selenium, uranium, and molybdenum as shown in table 15 .

TABLE 15.-Toxic elements, in parts per million, in spring water and in the ash of associated vegetation in Yellow Cat area

[Analysts: C. E. Thompson and E. J. Fennelly]

\begin{tabular}{|c|c|c|c|c|c|}
\hline Sample & Water and plants & Se & $\mathrm{U}$ & Mo & V \\
\hline $\begin{array}{r}\text { GX-57-1794 } \\
1795-\cdots \\
1800\end{array}$ & $\begin{array}{l}\text { Water from Cactus Rat spring } \\
\text { Water from Cactus Rat seep }\end{array}$ & $\begin{array}{l}3 \\
2 \\
1\end{array}$ & $\begin{array}{r}0.22 \\
.57 \\
60\end{array}$ & $\begin{array}{l}0.04 \\
.3\end{array}$ & \\
\hline D-70733 132 & $\begin{array}{l}\text { Plants from Cactus Rat spring: } \\
\text { Astragalus pattersoni } \\
\text { Elymus salina } 1\end{array}$ & $\begin{array}{r}46,000 \\
500\end{array}$ & $\begin{array}{r}13.6 \\
4.5\end{array}$ & $\begin{array}{r}150 \\
30\end{array}$ & 40 \\
\hline GX-57-1793_.... & Tamarix gallica $1-\ldots$ & 3,800 & $\begin{array}{r}10.6 \\
8.6\end{array}$ & $\begin{array}{l}10 \\
10\end{array}$ & 10 \\
\hline D-53519. & $\begin{array}{l}\text { Plants from Cactus Rat seep: } \\
\text { Hilaria jamesi. }\end{array}$ & & 1.7 & & \\
\hline 31 & $\begin{array}{l}\text { Gutierrezia divaricata } \\
\text { Grindelia fastigiata }\end{array}$ & $\begin{array}{l}3,800 \\
5,200\end{array}$ & $\begin{array}{l}9.3 \\
4.9\end{array}$ & $\begin{array}{l}200 \\
500\end{array}$ & $\begin{array}{l}60 \\
40\end{array}$ \\
\hline GX-56-1030 $\ldots$ & Filamentous algae. & & 54 & & \\
\hline \multicolumn{2}{|c|}{$\begin{array}{l}\text { A verage content of phreatophyte } \\
\text { A verage content of xerophyte }\end{array}$} & $\begin{array}{r}2,600 \\
18,000\end{array}$ & $\begin{array}{l}8 \\
7.4\end{array}$ & $\begin{array}{r}25 \\
280\end{array}$ & $\begin{array}{r}9 \\
70\end{array}$ \\
\hline
\end{tabular}

1 Phreatophyte.

The uranium content of all three waters is extremely high, but whether the uranium is in a form dangerous to humans is not known. Algae collected from a water trough at the Yellow Cat Campsite contained $54 \mathrm{ppm}$ uranium.

Selenium values in 44 samples of drinking water from the Western United States were reported by Trelease and Beath (1949, p. 222) to range from 0 to $0.33 \mathrm{ppm}$. One-half part per million selenium in drinking water is considered dangerous to human health. The samples analyzed for this project contained 1-3 ppm selenium (table 15). Phoenix (1959; and table 14 of this report) found $7.87 \mathrm{ppm}$ selenium in the Cactus Rat spring in 1950. The spring at the Yellow Cat Campsite is used as the source of water by many miners and their families in the area. No disability is known to have resulted from its use. The Cactus Rat spring, on the other hand, is toxic and was nearly fatal to several miners who used the water for domestic purposes for several months. The symptoms were those of selenium poisoning.

D. A. Phoenix (oral communication, 1952) suggested that the phreatophytes rooted in the spring waters be analyzed, for he believed that these plants had tremendous absorption and transpiration 
capabilities and should concentrate the available elements to a remarkable degree. No such phenomenon is apparent from the data. The concentration of elements is dependent on the chemistry of the cells of a particular genus or family and has little relation to the transpiration of water except as the water carries the ions through this "outer space" of the plant in the initial absorption stages and places them within reach of the cells. Metallic ions are thus moved upward along with water chiefly through xylem tissues, but excess elements that are not transferred from this part of the conduction system to other tissues may then move down.ward through the phloem and out of the plant (Crafts, Currier, and Stocking, 1949). In the Yellow Cat area, other species are more common and more useful for analytical purposes than are the phreatophytes. Phreatophytes are thus not a favorable medium for prospecting in the Yellow Cat area.

\section{PROSPECTING BY SOIL ANALYSIS}

A well-developed residual soil is lacking in the Yellow Cat area. The sandstone mesas are generally swept bare along the rims, and windblown sand accumulates in low areas and along weathered fractures in the interior of the mesas. Talus deposits have accumulated along the base of the sandstone cliffs, and alluvial deposits have collected along the main drainage systems of the area. On the lower flatter parts of the area, dune sand of two ages has accumulated. These sands were not considered as a medium for prospecting, but information obtained from the drilling program suggests that a migration of uranium and selenium from the bedrock into the overlying dune sand may have taken place where water conditions were favorable. A migration of vanadium from the Phosphoria Formation into similarly unrelated soils was described by Lotspeich (1958), who attributed the phenomenon to capillarity (transevaporation).

As the old mines in the Yellow Cat area are along and have contaminated all the streams in the district, the area seemed unfavorable for prospecting by stream alluvium; sampling of talus colluvium seemed to offer more promise as a prospecting tool in the Yellow Cat area. Therefore, the uranium content of 125 colluvial samples collected around the base of Yellow Cat Mesa and 23 samples collected along the base of the McCoy bench was determined. Samples were collected at ground intervals of 100 feet; the background value was determined to be $0.5 \mathrm{ppm}$ uranium. Results of the uranium tests are shown by symbol on plates 1 and 2. The McCoy samples ranged from $30 \mathrm{ppm}$ vanadium and $0.53 \mathrm{ppm}$ uranium at the east end of the traverse to values of ore grade where the colluvium below the mines is contaminated with dump material. Samples from Yellow Cat Mesa are considerably more significant as only two mine dumps were passed 
on a traverse of more than 2 miles. Samples collected below the two mines contained as much as $61 \mathrm{ppm}$ uranium and $40 \mathrm{ppm}$ vanadium; traverses along two other areas on the southeast rim contained 18, 23, 30,12 , and $47 \mathrm{ppm}$ uranium. These rim areas have since been found to be mineralized and are being mined at the present time (1961). Samples from a small area on the north side of the main part of the mesa contained $21 \mathrm{ppm}$ uranium. This area has not been tested, but it undoubtedly includes mineralized rock close to the outcrop. Selenium and molybdenum contents were too erratic to be useful; vanadium contents were considerably greater in mineralized areas and could be used in prospecting. These results show that colluvial sampling for uranium or vanadium along rim outcrops is a useful means of prospecting for ore.

\section{BOtANICAL PROSPECTING IN THE YELLOW CAT AREA}

EFFECT OF SHALLOW OXIDIZED ORE ON VEGETATION

In the alkaline soils of the Yellow Cat area, soluble compounds of molybdenum, selenium, uranium, sulfur, and vanadium occur in varying amounts and thus are available for plant absorption. Iron, cobalt, nickel, copper, and manganese are less available at a $\mathrm{pH}$ of 7-7.5 than at lower $\mathrm{pH}$ values and have little effect on the vegetation. Where there are an excess of metallic elements and a local change in the $\mathrm{pH}$ that influences the availability of normal soil constituents, the vegetation must adapt itself for continued existence. Depending on the chemistry of the various plant groups, different species may have different tolerance ranges for concentrations of these elements. The plants absorb large quantities of the soluble elements, and their distribution is influenced by their tolerance for these elements. For an understanding of these effects and their possible use as guides in prospecting, a discussion of the mechanism of ion absorption and transport within the plant may be helpful.

\section{ION ABSORPTION AND TRANSPORT}

Radioactive tracers in physiological experiments have led to a new understanding of the mechanism of ion absorption and accumulation by plants. Much of this work has been done by Epstein $(1955,1956)$, who first differentiated plant tissue into "outer space" and "inner space." He defined "outer space" as that fraction of the cytoplasm that is reversibly accessible to ions by diffusion. By this mechanism an ion from the soil solution-in fact, the entire soil solution-is free to move by diffusion from the roots to the leaves along-with water; but an accumulation of ions in outer space cannot take place over and above that of the soil solution because the movement is controlled by a concentration gradient and is reversible. He defined "inner space" 
as that fraction of the plant tissue (vacuoles, mitochondria, and ion binding sites) in which ions are accumulated by base exchange and active transport. By these methods; ions are brought from outer space into the vacuole by means of a carrier (active transport) or by cation exchange. Ions brought into a cell by active transport are irreversibly fixed. The process is highly selective and results in an accumulation of certain ions within the cell vacuole. Kramer (1957 p. 635) pointed out that all movement of ions in the xylem and phloem, then, is probably through the outer space, and ion exchange in the soil is only significant insofar as it affects the composition of the soil solution. Factors that affect accumulation (as $\mathrm{pH}$ of solution, external concentration, and metabolism) operate at the surface or within cells rather than at the outer root surface. For rapidly absorbed ions, the actively transported ions may represent a large percentage of the total, whereas for slowly absorbed ions the diffusible and exchangeable ions may be in greater abundance. These differences in rates and methods of absorption result in variations in the metal ratio between the root and above-ground parts of the plant. In plants having a high transpiration rate, there is only a slight tendency to concentrate salts in the outer space.

The concept of inner and outer space would not seem to alter several previously established facts in regard to accumulation: namely, that an ion exchange process in which $\mathrm{H}^{+1}$ ions are exchanged for metals and $\mathrm{OH}^{-1}$ and $\mathrm{HCO}_{3}^{-1}$ ions are exchanged for other anions plays a significant part in ion accumulation (Mehlich and Drake, 1955 , p. 291); that the ion exchange capacity of the root is significant at least in accumulating ions within the root; and that the anions such as citrates, acetates, malates, tartrates, and various amino acids that occur throughout the plant act as carriers of trace metals (Haertl and Martell, 1956) in the form of metal chelate compounds. The concept also does not invalidate the more specific work by Rothstein (1953) on the uptake of uranium. He showed that a rapid phase of uranium uptake (over and above the concentration of the medium) is associated with the formation of complexes having groups on the cell surface. This is followed by a slow continued phase of uranium uptake that is probably associated with penetration into the cell. Rothstein and Meier (1953) showed that bivalent cations such as $\mathrm{Ba}^{+2}, \mathrm{Ca}^{+2}, \mathrm{Be}^{+2}, \mathrm{Mg}^{+2}$, and $\mathrm{Zn}^{+2}$ can compete with the uranium ion for cell-surface loci; $\mathrm{Na}^{+1}$ and $\mathrm{K}^{+1}$ cannot. They theorized that the uranium-complexing loci of the cell surface are polymers of phosphate and that the uranyl ion inhibits sugar metabolism by forming undissociated complexes with these polyphosphates (possibly replacing $\mathrm{Ca}^{+2}$ and $\mathrm{Mg}^{+2}$ ). 
If all these chemical reactions have been accurately defined, plants having a high transpiration rate would be expected to transport the greatest numbers of ions to the upper parts of the plant where they are available for accumulation, and those plants having the greatest ion exchange capacity in their roots would be expected to accumulate and precipitate large quantities of metals in the roots. The accumulation of salts within a unit cell is partly a response to the nutritional requirement of the plant and partly a response to the chemical environment setup within the plant; but salt accumulation is not in any way necessary to, and perhaps is detrimental to, the health of the plant. If any element is available to the plant in excess of its normal requirements or, conversely, is made unavailable in an ore environment so as to be deficient, the plants may exhibit a difference in appearance, size, or density that may be a useful guide in prospecting.

\section{EFFECT OF MINERAL EXCESSES ON GROWTH HABITS AND COMPOSITION OF THE VEGETATION}

As has already been shown in this report, the elements available to plants in excessive amounts near the carnotite deposits of the Yellow Cat area are uranium, vanadium, selenium, molybdenum, and sulfur. The amounts of these elements absorbed by plants varies according to the species, the part of the plant sampled, the season, and the rainfall conditions. Preliminary studies of the plants in the Yellow Cat area and analyses of about 70 plant samples have been published (Cannon, 1952). The metal content of all plants collected for research purposes (exclusive of line-traverse samples) and the accompanying soil analyses, wherever available, are given in table 16 . Variations in absorption of uranium, vanadium, selenium, lead, and molybdenum were investigated in great detail. Significantly, all species of plants rooted in mineralized ground contained more uranium, vanadium, and selenium than did those rooted in barren or unmineralized ground. Most of the samples, including those of concentrator species, were collected from oxidizing ore deposits. Therefore, their uranium, vanadium, and selenium contents are higher than those in tree samples collected in traverse sampling across mineralized but undisturbed ground. Average contents of elements in the aerial parts of grasses, woody plants, and herbs have been compiled in table 17 .

The ratio of uranium content in plants growing on mineralized ground to that in plants growing on barren ground was greater than 
the ratio for any other element. The uranium content in woody plants was found to be consistent and useful in outlining uraniferous ground. Selenium ratios were not computed because the plants analyzed for selenium were largely selenium-accumulating species. Lead ratios are not useful because lead is not accumulated by herbaceous species, although a small difference between contents in mineralized and barren ground was found in woody plants. All species of plants rooted in mineralized ground were found to contain concentrations of vanadium and molybdenum that could be used as guides in prospecting. The molybdenum content, however, varied markedly between collections.

A comparison is also made in table 16 between uranium content of the aerial parts and that of the roots of the plants. In general, contents of uranium and vanadium were greater in the roots than in the leafy parts of the plants and were low in the berries of the juniper; contents of molybdenum and lead did not show any marked difference between the roots and the aerial parts. All the roots were washed to avoid soil contamination, although Epstein (1956) and Long, Sweet, and Tukey (1956) showed that the diffused ions can be washed out of the plant; so the values shown for roots probably are low. Several root samples of juniper were also peeled to determine whether the metals were actually absorbed by the root tissues. As tests showed that the peeled root, or xylem tissue, contained more uranium and vanadium than did the root bark, the values obtained for root samples thus represent a content of metal that has been actually absorbed by the root and accumulated in the xylem tissue. Ratios of uranium, vanadium, and molybdenum contents in the roots as compared to the tops of grasses, woody plants, and other herbs are shown in table 18 .

Concentrations of uranium and molybdenum are greater in the roots of forbs than in roots of grasses; the reverse is true of vanadium. The difference in transport of uranium and vanadium in the various plant groups may be related to the high ratio of potassium to calcium in the tops of grasses and the low exchange capacity of the roots as compared to herbs and especially legumes (Mehlich and Drake, 1955). Of the species analyzed, the largest accumulation of uranium in the above-ground parts of the plant was found in onions; the largest accumulations of vanadium, molybdenum, and selenium are found in legumes and crucifers. The absorption of these ore metals and their effect on plants will be discussed by individual element. 
TABLE 16.-Metal content, in parts per million, of plants and

[Specimen indicates individual plant sampled. Part of plant sampled: letters indicate side of tree nearest sample; D, sample at depth. Analysts: I. H. Barlow, E. F. Cooley, H. E. Crowe, E. J. Fennelly, D. F. R. L. Meyrowitz, A. T. Myers, W. O. Robinson, J. J. Rowe, Leonard Shapiro, Alexander Sherwood, Thompson, and H. W. Lakin]

\begin{tabular}{|l|l|l|c|c|c|c|}
\hline Source of sample & $\begin{array}{c}\text { Spec- } \\
\text { imen }\end{array}$ & $\begin{array}{c}\text { Part of plant } \\
\text { sampled }\end{array}$ & $\begin{array}{c}\text { Degree } \\
\text { of min- } \\
\text { eraliza- } \\
\text { tion }\end{array}$ & $\begin{array}{c}\text { Date of } \\
\text { collec- } \\
\text { tion }\end{array}$ & $\begin{array}{c}\text { Field or } \\
\text { laboratory } \\
\text { No. }\end{array}$ & $\begin{array}{c}\text { Ash, } \\
\text { in } \\
\text { per- } \\
\text { cent }\end{array}$ \\
\hline
\end{tabular}

Artemisia

\begin{tabular}{|c|c|c|c|c|c|c|}
\hline $\begin{array}{l}\text { Little Pittsburg } 3 \\
\text { Yellow Cat Mesa }\end{array}$ & $\begin{array}{l}\mathbf{A} \\
\mathbf{B}\end{array}$ & 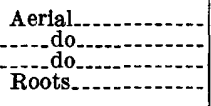 & $\begin{array}{l}\mathrm{M} \\
\mathrm{U} \\
\mathrm{U} \\
\mathrm{U}\end{array}$ & $\begin{array}{l}5-1-57 \\
5-19-49 \\
8-29-49 \\
5-19-49\end{array}$ & $\begin{array}{l}\text { GX-571810 } \\
\text { P54 } \\
\text { P54F } \\
\text { P55 }\end{array}$ & $\begin{array}{r}9.1 \\
9.7 \\
11.3\end{array}$ \\
\hline
\end{tabular}

\begin{tabular}{l|l|l|l|l|l|l|}
\hline & \multicolumn{3}{c}{ Artemisia } \\
\hline Telluride 3......................... & A & Aerial_............ & M & 5-16-49 & P56 & 18.4 \\
Roots_............ & P57 & 13.2 \\
\hline
\end{tabular}

Atriplex

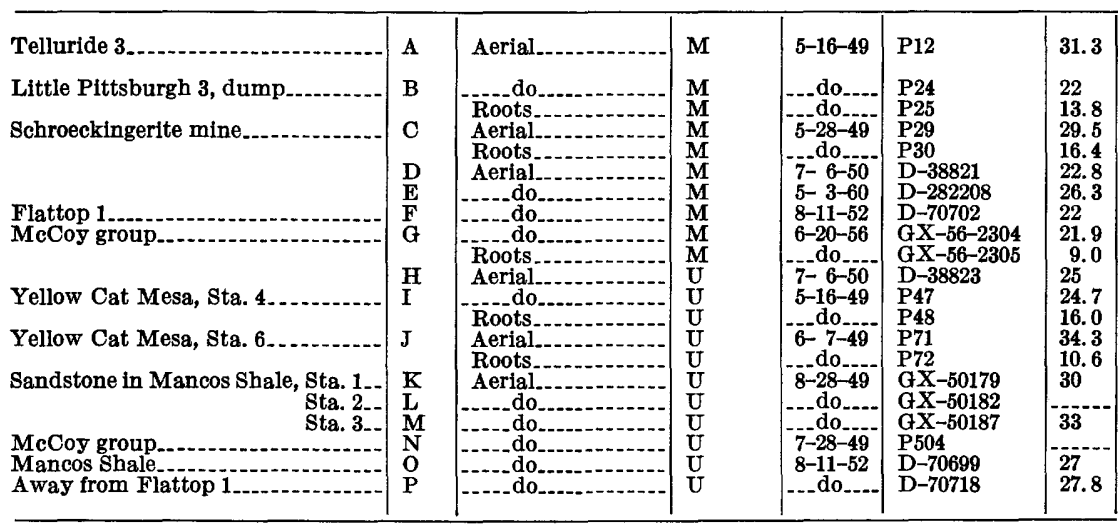

Artriplex

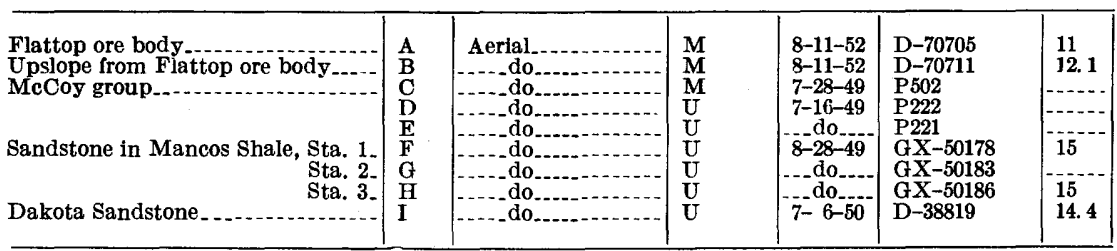

Chrysothamnus

\begin{tabular}{|c|c|c|c|c|c|c|}
\hline Little Pittsburg 3, alluvium & A & Aerial_- & $\mathbf{M}$ & $5-16-49$ & $\begin{array}{l}\mathrm{P} 22 \\
\mathrm{P} 23\end{array}$ & $\begin{array}{l}17.3 \\
16.8\end{array}$ \\
\hline $\begin{array}{l}\text { Little Pittsburg 3, rooted in ore at } 8 \\
\text { ft }\end{array}$ & $\mathbf{B}$ & Aerial. & $\mathbf{M}$ & & & 8. 3 \\
\hline $\begin{array}{l}\text { McCoy group, Sta. 3.-. } \\
\text { Yellow Cat Mesa. Sta. } 4\end{array}$ & $\stackrel{\mathrm{C}}{\mathrm{D}}$ & $\begin{array}{l}\text { Roots } \\
\text { Aerial_. }\end{array}$ & $\begin{array}{l}\mathbf{M} \\
\mathbf{M} \\
\mathbf{U}\end{array}$ & $\begin{array}{l}5-2-57 \\
5-19-49\end{array}$ & $\begin{array}{l}\text { P17 } \\
\text { GX-57-1817 } \\
\text { P45 }\end{array}$ & $\begin{array}{l}14.7 \\
19.9 \\
13.2\end{array}$ \\
\hline 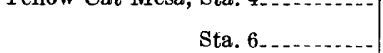 & $\mathbf{E}$ & $\begin{array}{l}\text { Roots } \\
\text { Aerial }\end{array}$ & $\begin{array}{l}\mathrm{U} \\
\mathrm{U}\end{array}$ & $6-7-49$ & & $\begin{array}{l}14.6 \\
11.7\end{array}$ \\
\hline Dakota Sandstone... & $\mathbf{F}$ & $\begin{array}{l}\text { Roots } \\
\text { Aerial }\end{array}$ & $\begin{array}{l}\mathrm{U} \\
\mathrm{U}\end{array}$ & $7-6-50$ & & $\begin{array}{r}14.7 \\
7.6\end{array}$ \\
\hline
\end{tabular}


associated soils collected in the Yellow Cat area, Grand County, Utah

ore. Degree of mineralization: M, mineralized; U, unmineralized. Analytical data for soils: S, surface Greene, F. S. Grimaldi, N. S. Guttag, C. H. Huffman, Jr., Ruth Kreher, Irving May, J. W. T. Meadows, Roberta Dymond, F. N. Ward, W. R. Weston, L. F. Rader, Jr., C. A. Horr, L. E. Reichen, C. E.

\begin{tabular}{|c|c|c|c|c|c|c|c|c|c|c|}
\hline \multicolumn{2}{|c|}{ Uranium } & \multicolumn{2}{|c|}{ Vanadium } & \multicolumn{3}{|c|}{ Selenium } & \multicolumn{2}{|c|}{ Molybdenum } & \multicolumn{2}{|c|}{ Lead } \\
\hline $\begin{array}{l}\text { Plant } \\
\text { ash }\end{array}$ & Soil & $\begin{array}{c}\text { Plant } \\
\text { ash }\end{array}$ & Soil & $\begin{array}{c}\text { Plant } \\
\text { dry } \\
\text { weight }\end{array}$ & $\begin{array}{c}\text { Plant } \\
\text { ash }\end{array}$ & Soil & $\begin{array}{c}\text { Plant } \\
\text { ash }\end{array}$ & Soil & $\begin{array}{l}\text { Plant } \\
\text { ash }\end{array}$ & Soil \\
\hline
\end{tabular}

\section{bigelovii}

\begin{tabular}{|c|c|c|c|c|c|c|c|c|c|c|}
\hline $2^{20.4}$ & 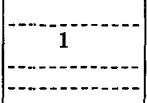 & $\begin{array}{r}150 \\
28 \\
39 \\
3\end{array}$ & $\mid \begin{array}{c}-123 \\
-123\end{array}$ & $\begin{array}{c}15 \\
-15 \\
-10\end{array}$ & $\begin{array}{r}165 \\
\end{array}$ & $\mid$\begin{tabular}{c}
---- \\
$-\cdots-$ \\
\hdashline--- \\
$-\cdots-$
\end{tabular} & $\begin{array}{r}30 \\
7 \\
7 \\
<7\end{array}$ & 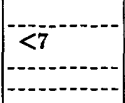 & $\begin{array}{r}30 \\
<10 \\
10 \\
30\end{array}$ & 10 \\
\hline
\end{tabular}

spinescens

\begin{tabular}{|c|c|c|c|c|c|c|c|c|c|c|}
\hline $\begin{array}{l}3 \\
5\end{array}$ & $\begin{array}{c}2(\mathrm{~S}) \\
290(\mathrm{D})\end{array}$ & $\begin{array}{l}39 \\
56\end{array}$ & $\begin{array}{r}80(\mathrm{~S}) \\
12,880(\mathrm{D})\end{array}$ & - & - & $-\cdots-$ & $\begin{array}{c}<7 \\
-\end{array}$ & $\begin{array}{l}<7(\mathrm{~S}) \\
13(\mathrm{D})\end{array}$ & $\begin{array}{l}<10 \\
<10\end{array}$ & $<\underset{30}{10}(\mathrm{~S})$ \\
\hline
\end{tabular}

\section{confertifolia}

\begin{tabular}{|c|c|c|c|c|c|c|c|c|c|c|}
\hline \begin{tabular}{|c}
2 \\
3 \\
5 \\
100 \\
30 \\
5.9 \\
30.0 \\
9.3 \\
6.5 \\
11.0 \\
.85 \\
.9 \\
1.0 \\
.2 \\
.2 \\
.04 \\
.10 \\
.26 \\
.33 \\
3.2 \\
1.4
\end{tabular} & 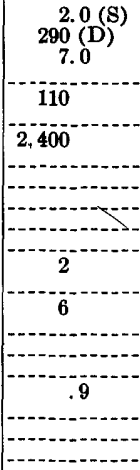 & \begin{tabular}{|c|c}
28 \\
5.6 \\
50 \\
90 \\
39 \\
8.4 \\
30 \\
40 \\
$<50$ \\
70 \\
8 \\
22 \\
39 \\
50 \\
28 \\
33 \\
22 \\
22 \\
12 \\
20 \\
40
\end{tabular} & $\begin{array}{c}100(\mathrm{~S}) \\
12,500(\mathrm{D}) \\
101 \\
174 \\
168 \\
67 \\
200 \\
1,200 \\
\\
\end{array}$ & \begin{tabular}{|c|}
170 \\
13 \\
200 \\
100 \\
170 \\
15
\end{tabular} & 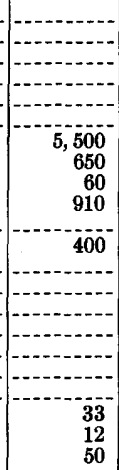 & 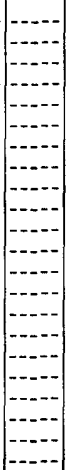 & $\begin{array}{r}13 \\
-7 \\
<7 \\
165 \\
20 \\
100 \\
300 \\
40 \\
30 \\
30 \\
20 \\
13 \\
7 \\
<7 \\
7 \\
20 \\
20 \\
10 \\
10 \\
30 \\
40\end{array}$ & 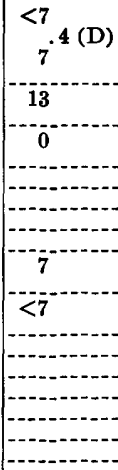 & 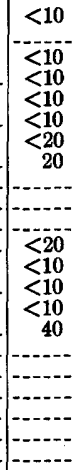 & $\begin{array}{c}<10(\mathrm{~S}) \\
30(\mathrm{D}) \\
<10 \\
<10 \\
3\end{array}$ \\
\hline
\end{tabular}

\section{canescens}

\begin{tabular}{|c|c|c|c|c|c|c|c|c|c|c|}
\hline $\begin{array}{l}4.5 \\
3.9 \\
1.8 \\
.56 \\
.45 \\
1 \quad .12 \\
.68 \\
.75\end{array}$ & $\begin{array}{c}.7 \\
1.1 \\
.9 \\
.6\end{array}$ & \begin{tabular}{|c|}
20 \\
\hdashline$-\overline{8}$ \\
12 \\
22 \\
17 \\
12 \\
$<5.6$ \\
14
\end{tabular} & \begin{tabular}{r}
28 \\
23 \\
\hdashline 1,200 \\
300
\end{tabular} & $\begin{array}{r}3.0 \\
225 \\
70 \\
17 \\
\\
\hdashline\end{array}$ & $\begin{array}{r}4 \\
25 \\
1,406 \\
4,188 \\
106\end{array}$ & 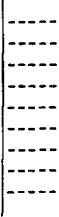 & 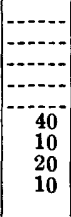 & 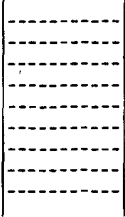 & 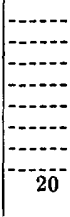 & $\left|\begin{array}{l}-1 \\
-1\end{array}\right|$ \\
\hline
\end{tabular}

\section{viscidiflorus}

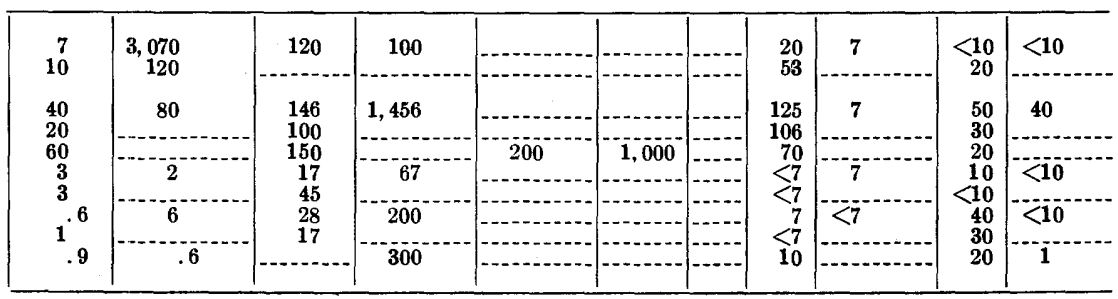


TABLE 16.-Metal content, in parts per million, of plants and associated

\begin{tabular}{|c|c|c|c|c|c|c|}
\hline Source of sample & $\begin{array}{l}\text { Spec- } \\
\text { imen }\end{array}$ & $\begin{array}{l}\text { Part of plant } \\
\text { sampled }\end{array}$ & $\begin{array}{l}\text { Degree } \\
\text { of min- } \\
\text { eraliza- } \\
\text { tion }\end{array}$ & $\begin{array}{l}\text { Date of } \\
\text { collec- } \\
\text { tion. }\end{array}$ & $\begin{array}{l}\text { Field or } \\
\text { laboratory } \\
\text { No. }\end{array}$ & $\begin{array}{l}\text { Ash, } \\
\text { in } \\
\text { per- } \\
\text { cent }\end{array}$ \\
\hline \multicolumn{7}{|c|}{ Coleogyne } \\
\hline Southeast of School Section. & $\begin{array}{l}\mathbf{A} \\
\mathbf{B} \\
\mathbf{C}\end{array}$ & \begin{tabular}{|c|} 
Leaves and twigs. \\
\end{tabular} & $\begin{array}{l}\mathbf{M} \\
\mathbf{M} \\
\mathbf{M}\end{array}$ & $\begin{array}{c}8-11-52 \\
--d o-\ldots \\
-d o\end{array}$ & $\begin{array}{l}\text { D-70691 } \\
\text { D-70692 } \\
\text { D-70693 }\end{array}$ & $\begin{array}{l}9.8 \\
7.0 \\
6.5\end{array}$ \\
\hline \multicolumn{7}{|c|}{ Cowania } \\
\hline $\begin{array}{l}\text { McCoy group, Sta. 8, } 4 \mathrm{ft} \text { above ore. } \\
\text { Flattop 1.. } \\
\text { McCoy group- Sta. 2. } \\
\text { McCoy group, } \\
\text { McCoy group. }\end{array}$ & $\begin{array}{l}\mathbf{A} \\
\mathbf{B} \\
\mathbf{C} \\
\mathbf{D} \\
\mathbf{E}\end{array}$ & \begin{tabular}{|l|} 
Leaves and twigs. \\
\\
\\
\end{tabular} & $\begin{array}{l}\mathbf{M} \\
\mathbf{M} \\
\mathbf{M} \\
\mathbf{M} \\
\mathrm{U}\end{array}$ & $\begin{array}{l}7-16-49 \\
8-30-49 \\
6-20-49 \\
5-2-57 \\
7-16-49\end{array}$ & $\begin{array}{l}P 224 \\
G X-50171 \\
G X-56-2312 \\
G X-57-1818 \\
G X-50172\end{array}$ & $\begin{array}{l}4.0 \\
4.6 \\
7.6 \\
4.0\end{array}$ \\
\hline
\end{tabular}

Ephedra

\begin{tabular}{|c|c|c|c|c|c|c|}
\hline Telluride 3, 5 ft above ore body & A & Aerial_-.. & $\mathbf{M}$ & $5-16-49$ & P10 & 14.7 \\
\hline McCoy group, rooted in ore at $18 \mathrm{ft}$. & B & Roots & $\begin{array}{l}\mathbf{M} \\
\mathbf{M}\end{array}$ & $\begin{array}{r}5-18-49 \\
- \text { do }\end{array}$ & $\begin{array}{l}\text { P33 } \\
\text { P34 }\end{array}$ & $\begin{array}{r}6.3 \\
10.9\end{array}$ \\
\hline McCoy group, Sta. 2.- & $\mathrm{C}$ & Aerial.-- & $\mathbf{M}$ & $5-2-57$ & GX-57-1816 & 11. 0 \\
\hline McCoy group.........- & & Roots. & $\mathbf{M}$ & $\begin{aligned} 6-20-56 \\
-. d o\end{aligned}$ & $\begin{array}{l}G X-50-2300 \\
G X-56-2307\end{array}$ & $\begin{array}{l}8.0 \\
4.6\end{array}$ \\
\hline $\begin{array}{l}\text { Schroeckingerite mine } \\
\text { Yellow Cat Mesa, Sta, } 4 .\end{array}$ & $\underset{\mathbf{F}}{\mathbf{E}}$ & Aerial- & $\underset{\mathbf{U}}{\mathbf{M}}$ & $\begin{array}{l}5-3-60 \\
5-19-49\end{array}$ & $\begin{array}{l}\text { D-282207 } \\
\text { P43 }\end{array}$ & $\begin{array}{l}9.6 \\
8.9\end{array}$ \\
\hline 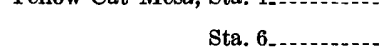 & G & $\begin{array}{l}\text { Roots } \\
\text { Aerial }\end{array}$ & $\frac{\mathrm{U}}{\mathrm{U}}$ & $\begin{array}{l}-d o \\
6-7-49\end{array}$ & & $\begin{array}{r}6.9 \\
12.5\end{array}$ \\
\hline Dakota Sandstone & $\mathbf{H}$ & $\begin{array}{l}\text { Roots } \\
\text { Aerial_......... }\end{array}$ & $\begin{array}{l}\mathbf{U} \\
\mathbf{U}\end{array}$ & $\begin{array}{l}-d 0-2-57 \\
5-2-7\end{array}$ & $\stackrel{P}{G \times 8}-57-1790$ & $\begin{array}{r}\text { 8. } 1 \\
13.0\end{array}$ \\
\hline
\end{tabular}

Fraxinus

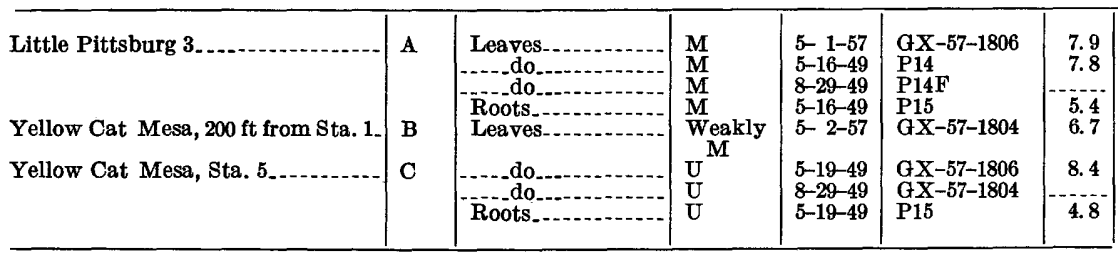

Juniperus

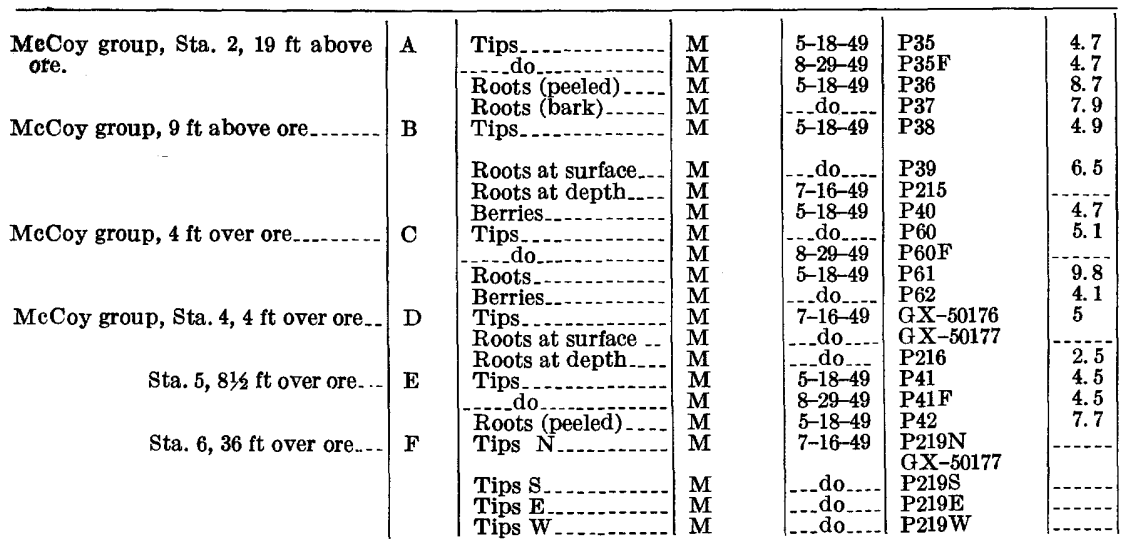


soils collected in the Yellow Cat area, Grand County, Utah-Continued

\begin{tabular}{|c|c|c|c|c|c|c|c|c|c|c|}
\hline \multicolumn{2}{|c|}{ Uranium } & \multicolumn{2}{|c|}{ Vanadium } & \multicolumn{3}{|c|}{ Selenium } & \multicolumn{2}{|c|}{ Molybdenum } & \multicolumn{2}{|c|}{ Lead } \\
\hline $\begin{array}{l}\text { Plant } \\
\text { ash }\end{array}$ & Soil & $\begin{array}{l}\text { Plant } \\
\text { ash }\end{array}$ & Soil & $\begin{array}{c}\text { Plant } \\
\text { dry } \\
\text { weight }\end{array}$ & $\begin{array}{c}\text { Plant } \\
\text { ash }\end{array}$ & Soil & $\begin{array}{l}\text { Plant } \\
\text { ash }\end{array}$ & Soil & $\begin{array}{c}\text { Plant } \\
\text { ash }\end{array}$ & Soil \\
\hline
\end{tabular}

\section{ranosissime}

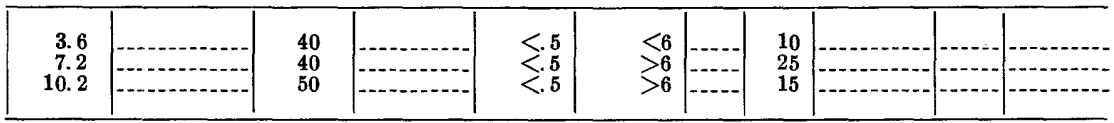

\section{stansburiana}

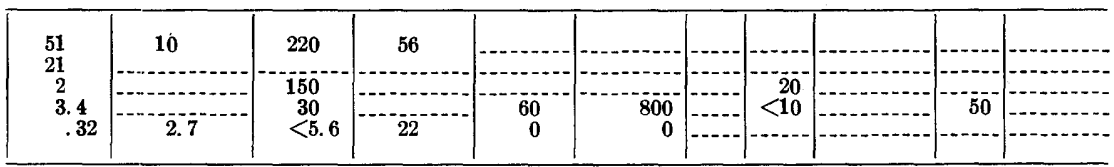

\section{viridis}

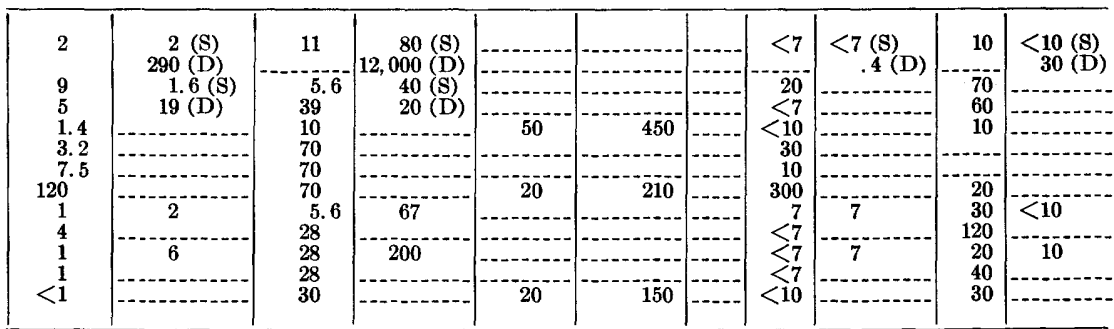

\section{anomala}

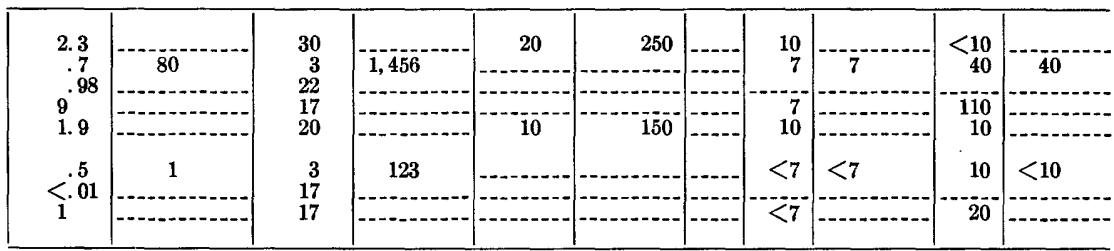

\section{monosperma}

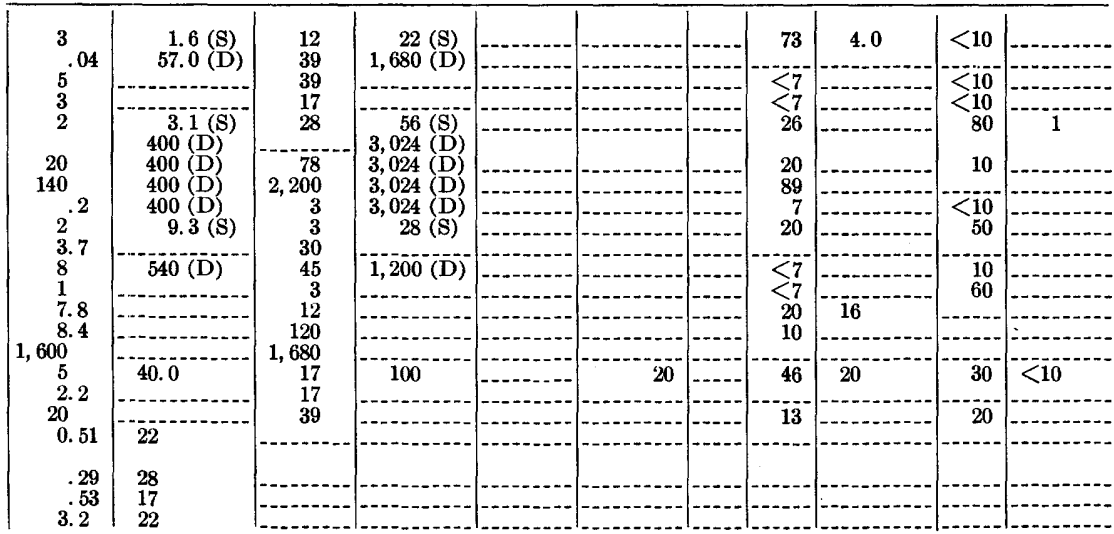


TABLE 16.-Metal content, in parts per million, of plants and associated

\begin{tabular}{c|c|c|c|c|c|c|}
\hline Source of sample & $\begin{array}{c}\text { Spec- } \\
\text { imen }\end{array}$ & $\begin{array}{c}\text { Part of plant } \\
\text { sampled }\end{array}$ & $\begin{array}{c}\text { Degree } \\
\text { of min- } \\
\text { eraliza- } \\
\text { tion }\end{array}$ & $\begin{array}{c}\text { Date of } \\
\text { collec- } \\
\text { tion }\end{array}$ & $\begin{array}{c}\text { Field or } \\
\text { laboratory } \\
\text { No. }\end{array}$ & $\begin{array}{c}\text { Ash, } \\
\text { in } \\
\text { per- } \\
\text { cent }\end{array}$ \\
\hline
\end{tabular}

Juniperus

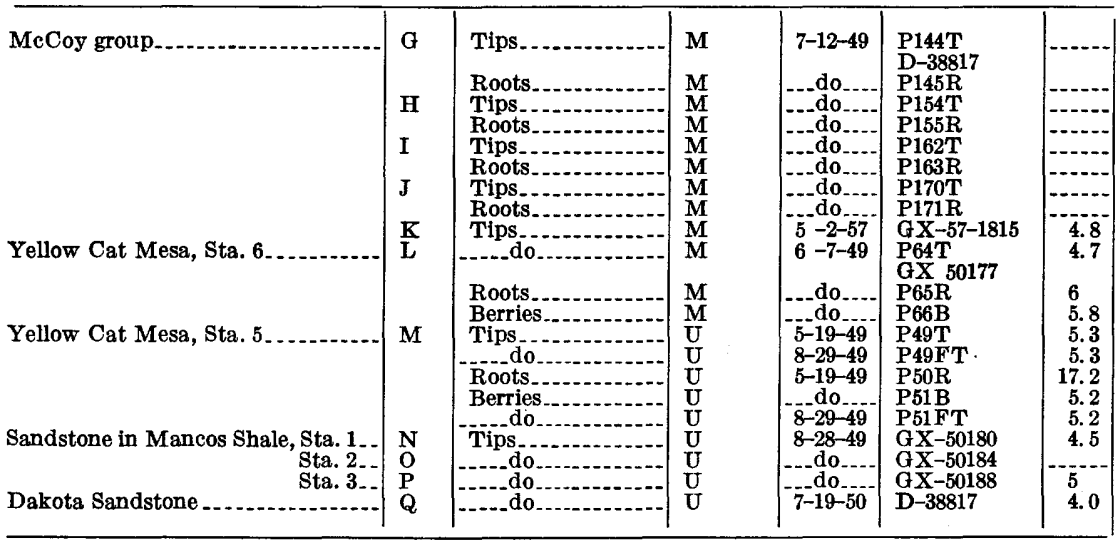

Quercus

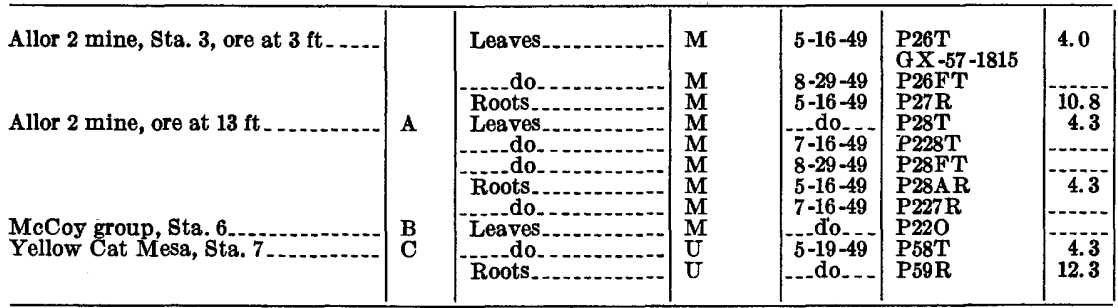

Sarco batus

\begin{tabular}{|c|c|c|c|c|c|c|}
\hline $\begin{array}{l}\text { McCoy group, Sta. } 2,19 \mathrm{ft} \text { above } \\
\text { ore }\end{array}$ & $\mathbf{A}$ & Tips_._. & M & $7-16-49$ & P213T & 17 \\
\hline Sandstone in Mancos Shale, Sta. 1 Sta. & $\stackrel{B}{\mathrm{~B}}$ & $\begin{array}{l}\text { Roots at } 19 \mathrm{ft} \\
\text { Tips }\end{array}$ & $\begin{array}{l}\mathrm{M} \\
\mathrm{U} \\
\mathrm{U}\end{array}$ & $8-28-49$ & $\begin{array}{l}\text { P211R } \\
\text { GX }-50181 \\
\text { GX }-50185\end{array}$ & 17 \\
\hline Mancos Shale & $\underset{\mathbf{E}}{\mathrm{D}}$ & (ndo & $\stackrel{\mathrm{U}}{\mathrm{U}}$ & $8-11-52$ & $\begin{array}{l}\mathrm{GX}-50189 \\
\mathrm{D}-70685\end{array}$ & $\begin{array}{l}25 \\
17\end{array}$ \\
\hline
\end{tabular}

Tamarix

\begin{tabular}{|c|c|c|c|c|c|c|}
\hline Cactus Rat Spring. & A & Tips_... & M & $7-6-50$ & D-38825 & 11.6 \\
\hline $\begin{array}{l}\text { Schroeckingerite deposit_. } \\
\text { Mancos Shale. }\end{array}$ & $\begin{array}{l}\mathrm{C} \\
\mathrm{B} \\
\mathrm{D}\end{array}$ & -.do & $\begin{array}{l}\mathrm{M} \\
\mathrm{M} \\
\mathbf{U}\end{array}$ & $\begin{array}{l}4-30-57 \\
6-20-56 \\
5-2-57\end{array}$ & $\begin{array}{l}G X-57-1793 \\
G X-55-2300 \\
G X-57-1823\end{array}$ & $\begin{array}{r}11.0 \\
11.6 \\
9.4\end{array}$ \\
\hline
\end{tabular}

Yucca

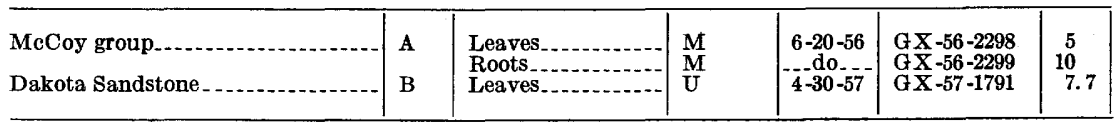


GEOCHEMICAL PROSPECTING IN THE YELLOW CAT AREA

soils collected in the Yellow Cat area, Grand County, Utah-Continued

\begin{tabular}{|c|c|c|c|c|c|c|c|c|c|c|}
\hline \multicolumn{2}{|c|}{ Uranium } & \multicolumn{2}{|c|}{ Vanadium } & \multicolumn{3}{|c|}{ Selenium } & \multicolumn{2}{|c|}{ Molybdenum } & \multicolumn{2}{|c|}{ Lead } \\
\hline $\begin{array}{l}\text { Plant } \\
\text { ash }\end{array}$ & Soil & $\begin{array}{c}\text { Plant } \\
\text { ash }\end{array}$ & Soil & $\begin{array}{c}\text { Plant } \\
\text { dry } \\
\text { welght }\end{array}$ & $\underset{\text { ash }}{\text { Plant }}$ & Soil & $\underset{\text { ash }}{\text { Plant }}$ & Soil & $\begin{array}{c}\text { Plant } \\
\text { ash }\end{array}$ & Soil \\
\hline
\end{tabular}

monosperma-Continued

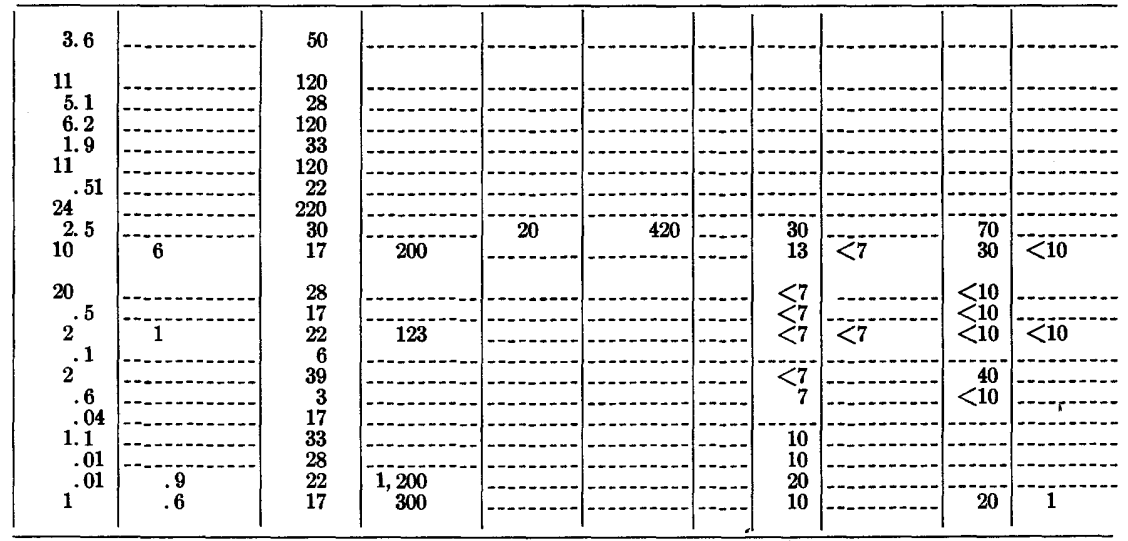

\section{gambelii}

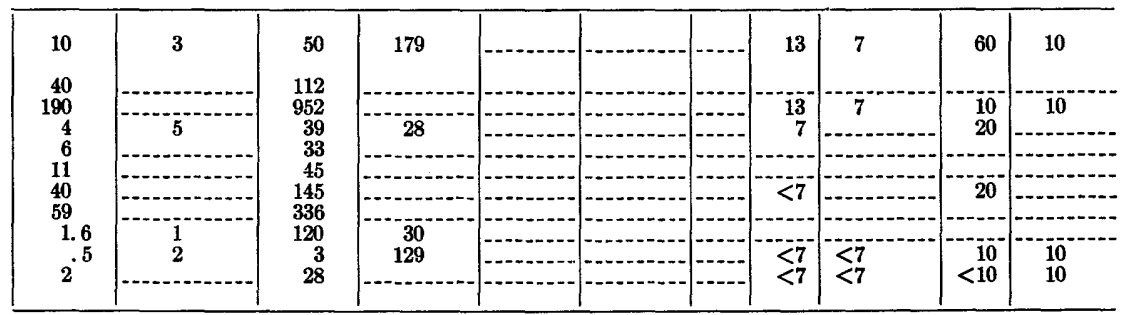

\section{vermiculatus}

\begin{tabular}{|c|c|c|c|c|c|c|c|c|c|c|}
\hline 1.3 & .72 & 22 & 12 & -- & -0 & --- & & $-\ldots$ & $\ldots$ & \\
\hline 11 & 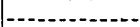 & 120 & $.-1--1-2$. & $-\ldots$ & & $\ldots$ & $-\ldots--$ & 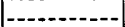 & $\ldots \ldots$ & $-\cdots$ \\
\hline & 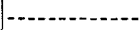 & 320 & 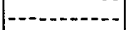 & $\ldots$ & $-\cdots$ & $-\cdots$ & $---\overline{0}$ & $-\cdots$ & $\ldots$ & $-\ldots$ \\
\hline .15 & 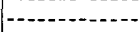 & 12 & 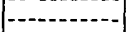 & $\ldots \ldots$ & - & $\ldots$ & 20 & - & $\cdots$ & $\ldots$ \\
\hline $\begin{array}{l}.17 \\
.19\end{array}$ & .9 & $\begin{array}{r}6 \\
12\end{array}$ & 1,200 & |- & |- & $\mid \cdots-$ & $\begin{array}{l}20 \\
20\end{array}$ & 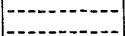 & $\mid \begin{array}{ll}-\infty \\
-n-n\end{array}$ & 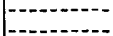 \\
\hline 5.1 & & 40 & - & 2.5 & 15 & $-\cdots$ & 15 & 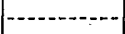 & $\ldots$ & - \\
\hline
\end{tabular}

\section{gallica}

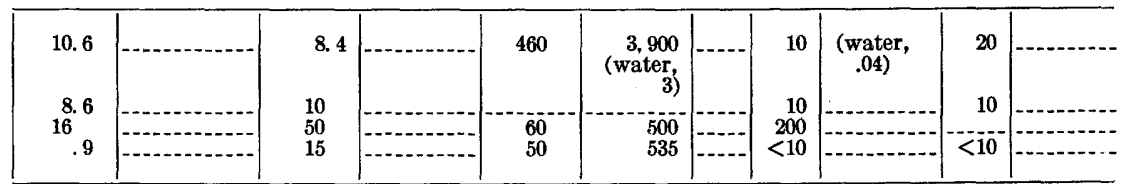

\section{harrimaniae}

\begin{tabular}{|c|c|c|c|c|c|c|c|c|c|c|}
\hline $\begin{array}{l}3 \\
9.6 \\
1.1\end{array}$ & 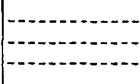 & $\begin{array}{r}70 \\
100 \\
10\end{array}$ & 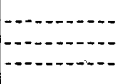 & $\begin{array}{r}4 \\
8 \\
30\end{array}$ & $\begin{array}{r}80 \\
80 \\
390\end{array}$ & 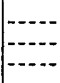 & $\begin{array}{r}30 \\
20 \\
<10\end{array}$ & 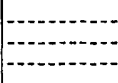 & -20 & 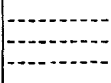 \\
\hline
\end{tabular}


TABLE 16.-Metal content. in parts per million, of plants and associated

\begin{tabular}{|c|c|c|c|c|c|c|}
\hline Source of sample & $\begin{array}{l}\text { Spec- } \\
\text { imen }\end{array}$ & $\begin{array}{l}\text { Part of plant } \\
\text { sampled }\end{array}$ & $\begin{array}{l}\text { Degree } \\
\text { of min- } \\
\text { eraliza- } \\
\text { tion }\end{array}$ & $\begin{array}{l}\text { Date of } \\
\text { collec- } \\
\text { tion }\end{array}$ & $\begin{array}{c}\text { Field or } \\
\text { laboratory } \\
\text { No. }\end{array}$ & $\begin{array}{c}\text { Ash, } \\
\text { in } \\
\text { per- } \\
\text { cent }\end{array}$ \\
\hline
\end{tabular}

Elymus

\begin{tabular}{|c|c|c|c|c|c|c|}
\hline Cactus Rat Spring. & A & Aerial_. & $\mathbf{M}$ & $8-11-52$ & D -707132 & 15 \\
\hline McCoy dumps... & B & -....-do_ & $\mathbf{M}$ & $4-27-52$ & $G X-5219$ & --- \\
\hline
\end{tabular}

Hilaria

\begin{tabular}{l|l|l|l|l|l|l|}
\hline Cactus Rat seep. & A & Aerial...................... & M & $11-51$ & D -53519 & $\ldots . . .-$ \\
\hline
\end{tabular}

Oryzopsis

\begin{tabular}{|c|c|c|c|c|c|c|}
\hline Dump of Telluride 3 mine. & A & Aerial............ & $\mathbf{M}$ & $5-16-49$ & P4T & 7.5 \\
\hline Rooted in ore of same mine & B & $\begin{array}{l}\text { Roots } \\
\text { Aerial }\end{array}$ & $\begin{array}{l}\mathbf{M} \\
\mathbf{M}\end{array}$ & -. do do & $\begin{array}{l}\text { P5R } \\
\text { P8T }\end{array}$ & $\begin{array}{r}38.4 \\
7.3\end{array}$ \\
\hline & & Roots & $\mathbf{M}$ & -.......... & P9R & 35.2 \\
\hline McCoy group, Sta. 7, DH849.. & $\mathbf{C}$ & Aerial. & $\mathbf{M}$ & $7-16-49$ & $\mathrm{~F} 223$ & 3. 9 \\
\hline Little Pittsburg mine & $\mathbf{D}$ & - & $\vec{M}$ & $4-27-55$ & $\mathrm{GX}-55-1823$ & 5.8 \\
\hline Sandstone in Mancos shale & $\mathbf{E}$ & - & $\mathrm{U}$ & $8-11-52$ & $\mathrm{D}-70688$ & 9.4 \\
\hline Brushy Basin Member & $\mathrm{F}$ & - & $\mathrm{U}$ & $5-3-60$ & $G X-60-4 B$ & 9.0 \\
\hline
\end{tabular}

Allium

\begin{tabular}{l|l|l|l|l|l|l|}
\hline In Pittsburg Park .................. & A & Entire........... & M & 5-56 & GX-57-1826 & 19 \\
\hline
\end{tabular}

Aster

\begin{tabular}{|c|c|c|c|c|c|c|}
\hline $\begin{array}{l}\text { MeCoy dumps } \\
\text { At YC } 378\end{array}$ & $\begin{array}{l}\text { A } \\
\text { B }\end{array}$ & Aerial & W & $\begin{array}{l}5-27-52 \\
5-1-57\end{array}$ & $\begin{array}{l}\text { GX-5220 } \\
\text { GX-57-1797 }\end{array}$ & $\begin{array}{l}15 \\
21.7\end{array}$ \\
\hline ancos Shr & $\mathrm{C}$ & $\ldots$ do & Weakly & $4-30-57$ & $G X-57-1789$ & 28.6 \\
\hline & D & ..... do & & $5-2-57$ & $G X-57-1814$ & 26.3 \\
\hline
\end{tabular}

Astragalus

\begin{tabular}{|c|c|c|c|c|c|c|}
\hline Cactus Rat mine & A & Aerial. & & $6-20-56$ & GX-56-2301 & 9 \\
\hline & B & Aerial. & & $5-27-52$ & $\mathrm{GX}-5223$ & \\
\hline Alluvium & $\mathrm{C}$ & ..... do & Weakly & $5-2-57$ & $G X-57-1820$ & 18.6 \\
\hline McCoy group, at YC 378..... & $\mathrm{D}$ & $\ldots \mathrm{do}_{\ldots} \ldots$ & Weakly & $5-1-57$ & $G \times-57-1798$ & 23.5 \\
\hline $\begin{array}{l}\text { Bobtail claims, blue clay } \\
\text { Mancos Shale, Sta. } 1\end{array}$ & $\frac{\mathbf{E}}{\mathbf{F}}$ & $\begin{array}{l}\text {-. do } \\
\text { Roots. } \\
\text { do }\end{array}$ & $\begin{array}{l}\mathrm{U} \\
\mathrm{U}\end{array}$ & $\begin{array}{r}7-28-49 \\
6-7-49 \\
--d o--\end{array}$ & $\begin{array}{l}\text { P500 } \\
\text { P73T } \\
\text { P74R }\end{array}$ & $\begin{array}{l}14.7 \\
18.8\end{array}$ \\
\hline
\end{tabular}

Astragalus

\begin{tabular}{|c|c|c|c|c|c|c|}
\hline Yellow Cat Mesa & A & $\begin{array}{l}\text { Aerial } \\
\text { Roots }\end{array}$ & $\mathrm{U}$ & $\begin{array}{r}5-19-49 \\
--d d o\end{array}$ & $\begin{array}{l}\text { P63T } \\
\text { P75R }\end{array}$ & $\begin{array}{r}11.3 \\
5.7\end{array}$ \\
\hline
\end{tabular}


GEOCHEMICAL PROSPECTING IN THE YELLOW CAT AREA

soils collected in the Yellow Cat area, Grand County, Utah-Continued

\begin{tabular}{|c|c|c|c|c|c|c|c|c|c|c|}
\hline \multicolumn{2}{|c|}{ Uranium } & \multicolumn{2}{|c|}{ Vanadium } & \multicolumn{3}{|c|}{ Selenium } & \multicolumn{2}{|c|}{ Molybdenum } & \multicolumn{2}{|c|}{ Lead } \\
\hline $\begin{array}{l}\text { Plant } \\
\text { ash }\end{array}$ & Soil & $\begin{array}{l}\text { Plant } \\
\text { ash }\end{array}$ & Soil & $\begin{array}{c}\text { Plant } \\
\text { dry } \\
\text { weight }\end{array}$ & $\begin{array}{l}\text { Plant } \\
\text { ash }\end{array}$ & Soil & $\begin{array}{c}\text { Plant } \\
\text { ash }\end{array}$ & Soil & $\underset{\operatorname{ash}}{\text { Plant }}$ & Soil \\
\hline
\end{tabular}

salina

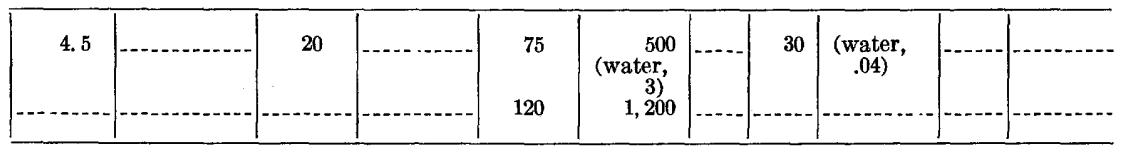

\section{jamesi}

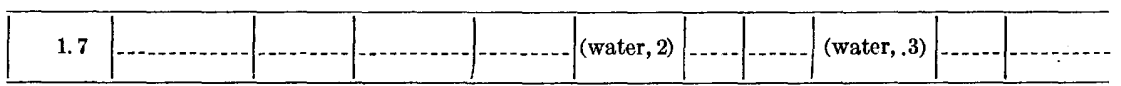

\section{hymenoides}

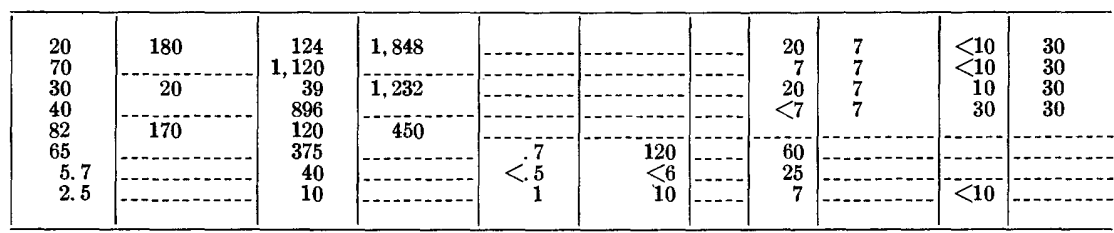

\section{macropetalum}

\begin{tabular}{|c|c|c|c|c|c|c|c|c|c|c|}
\hline 200 & - & 700 & - & 120 & 600 & -..- & 30 & 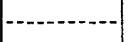 & 20 & $---n-$ \\
\hline
\end{tabular}

\section{venustus}

\begin{tabular}{|c|c|c|c|c|c|c|c|c|c|c|}
\hline $\begin{array}{l}\text { 7. } 4 \\
\text { 1. } 4\end{array}$ & $-2-2-1-2$ & 20 & $-\cdots-1$ & $\begin{array}{r}3,070 \\
600\end{array}$ & $\begin{array}{r}20,500 \\
2,765\end{array}$ & $-\ldots-$ & 700 & & $<10$ & \\
\hline 7.4 & 150 & $--1-2-1$ & & 50 & 170 & & 20 & & 50 & - \\
\hline .6 & 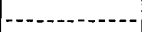 & 15 & - & 1,500 & 5,700 & $\ldots-$ & 300 & מיח & 10 & - \\
\hline
\end{tabular}

\section{confertiflorus}

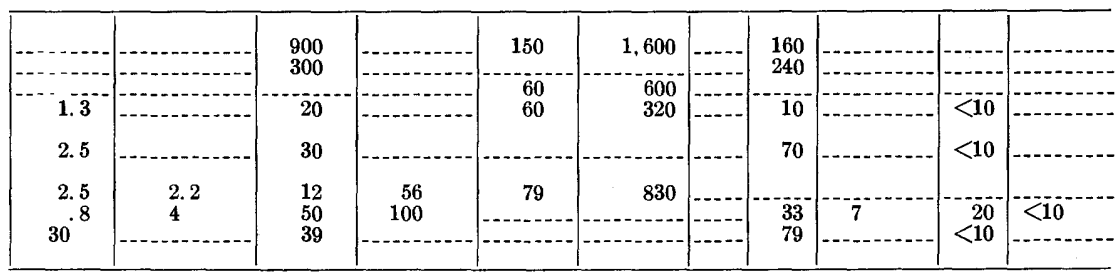

\section{desperatus}

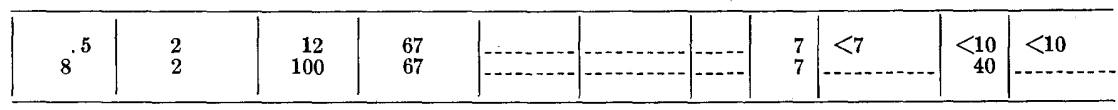


TABLE 16.-Metal content, in parts per million, of plants and associated

\begin{tabular}{|c|c|c|c|c|c|c|}
\hline Source of sample & $\begin{array}{l}\text { Spec- } \\
\text { imen }\end{array}$ & $\begin{array}{l}\text { Part of plant } \\
\text { sampled }\end{array}$ & $\begin{array}{l}\text { Degree } \\
\text { of min- } \\
\text { eraliza- } \\
\text { tion }\end{array}$ & $\begin{array}{l}\text { Date of } \\
\text { collec- } \\
\text { tion }\end{array}$ & $\begin{array}{c}\text { Field or } \\
\text { laboratory } \\
\text { No. }\end{array}$ & $\begin{array}{l}\text { Ash, } \\
\text { in } \\
\text { per- } \\
\text { cent }\end{array}$ \\
\hline \multicolumn{7}{|c|}{ Astragalus } \\
\hline Schroeckingerite mine...- & $\begin{array}{l}\mathrm{A} \\
\mathrm{B} \\
\mathrm{C} \\
\mathrm{D}\end{array}$ & $\begin{array}{l}\text { Aerial } \\
\text { Roots } \\
\text { Aerial } \\
\text { Aerial (healthy) }\end{array}$ & $\begin{array}{l}\mathrm{M} \\
\mathrm{M} \\
\mathrm{M} \\
\mathrm{M} \\
\mathrm{M}\end{array}$ & $\begin{array}{c}5-2-57 \\
5-18-49 \\
- \text { do- } \\
7-6-50 \\
8-11-52\end{array}$ & $\begin{array}{l}\text { GX-57-1811 } \\
\text { P31T } \\
\text { P32R } \\
\text { D-38820 } \\
\text { D-70733 }\end{array}$ & $\begin{array}{r}21.8 \\
18.5 \\
8.2 \\
11.6 \\
13\end{array}$ \\
\hline $\begin{array}{l}\text { Cactus Rat deposit } \\
\text { Parko 23-1 }\end{array}$ & $\begin{array}{l}\mathrm{E} \\
\mathrm{F}\end{array}$ & $\begin{array}{l}\text { Aerial (chlorotic) } \\
\text { Aerial }\end{array}$ & $\begin{array}{l}\mathbf{M} \\
\mathbf{M} \\
\mathbf{M}\end{array}$ & $\begin{array}{l}\text { do } \\
4-27-55 \\
6-20-56\end{array}$ & $\begin{array}{l}\text { D-70734 } \\
\text { GX-55-1826 } \\
\text { GX-56-2602 }\end{array}$ & $\begin{array}{r}9.3 \\
16.7 \\
26.6\end{array}$ \\
\hline Cactus Rat deposit. & $\mathrm{H}$ & Aerial (chlorotic) & M & $4-27-52$ & $\begin{array}{l}\mathrm{G} \\
\mathrm{GX}-5224\end{array}$ & 18 \\
\hline $\begin{array}{l}\text { Southeast of Schroeckingerite mine } \\
\text { East of McCoy cabin }\end{array}$ & $\begin{array}{l}\mathrm{I} \\
\mathrm{K}\end{array}$ & Aerial & $\begin{array}{l}\text { U } \\
U \\
U\end{array}$ & $\begin{array}{l}7-6-50 \\
7-28-49\end{array}$ & $\begin{array}{l}\text { D-38822 } \\
\text { P503 }\end{array}$ & 9.2 \\
\hline
\end{tabular}

Astragalus

\begin{tabular}{|c|c|c|c|c|c|c|}
\hline Telluride 3, dump & A & Aerial --- & $\mathrm{M}$ & $5-16-49$ & P1T & 9.5 \\
\hline & B & Aerial.-.- & $\mathbf{M}$ & $5-1-57$ & GX-57-1803 & 10.8 \\
\hline Little Pittsburg 3.. & $\mathrm{C}$ & - do & $\mathbf{M}$ & $5-16-49$ & $\begin{array}{l}\text { P18T } \\
\text { P19R }\end{array}$ & 19.0 \\
\hline & $\mathrm{D}$ & Aerial....- & $\mathbf{M}$ & $4-27-55$ & GX-551822 & 15.2 \\
\hline McCoy group & $\mathbf{E}$ & B...do_ & $\mathbf{M}$ & 6-20-56 & $\begin{array}{l}\mathrm{GX}-56-2296 \\
\mathrm{GX}-56-2297\end{array}$ & 8.3 \\
\hline MeCoy group dumps. . & $\mathbf{F}$ & Aerial................ & M & $4-27-52$ & $\mathrm{GX}-5217$ & 10.0 \\
\hline Schroeckingerite mi & $\mathrm{H}$ & do do & $\begin{array}{l}\mathbf{M} \\
\mathbf{M}\end{array}$ & $5-2-57$ & $\begin{array}{l}\text { GX-5218 } \\
\text { GX-57-1812 }\end{array}$ & $\begin{array}{l}10.0 \\
12.4\end{array}$ \\
\hline & I & $\begin{array}{l}\text { Aerial; has purple } \\
\text { flowers. }\end{array}$ & $\mathbf{M}$ & $4-16-58$ & & \\
\hline & $\mathbf{J}$ & $\begin{array}{l}\text { Aerial; has white } \\
\text { flowers. }\end{array}$ & $\mathbf{M}$ & -.-do & GX-5835 & 13 \\
\hline Blue clay -. - & $\mathbf{K}$ & Aerial & Weakly & $7-6-50$ & D-38824 & 9.0 \\
\hline Northwest Bobtail claim.... & $\mathbf{L}$ & _..._do_...... & $\begin{array}{l}\text { Weakly } \\
\mathbf{M}\end{array}$ & $7-28-49$ & P501 & $\cdots$ \\
\hline
\end{tabular}

Astragalus

\begin{tabular}{|c|c|c|c|c|c|c|}
\hline Cactus Rat & \multirow{2}{*}{$\begin{array}{l}\text { A } \\
\text { B }\end{array}$} & \multirow{2}{*}{ Aerial } & \multirow{2}{*}{$\begin{array}{c}\text { Weakly } \\
\text { M } \\
\text { Weakly } \\
\text { M }\end{array}$} & \multirow{2}{*}{$\begin{array}{l}4-27-55 \\
5-1-57\end{array}$} & \multirow{2}{*}{$\begin{array}{l}G X-55-1824 \\
G X-57-1809\end{array}$} & \multirow{2}{*}{$\begin{array}{r}34.9 \\
3.4\end{array}$} \\
\hline Yellow Car Mesa & & & & & & \\
\hline \multicolumn{7}{|r|}{ Bahic } \\
\hline Little Pittsburg 3, dump... & A & $\begin{array}{l}\text { Aerial } \\
\text { Roots }\end{array}$ & $\begin{array}{l}\mathrm{M} \\
\mathbf{M}\end{array}$ & $\begin{array}{c}5-16-49 \\
-\ldots \text { do.-. }\end{array}$ & $\begin{array}{l}\text { P20T } \\
\text { P21R }\end{array}$ & $\begin{array}{l}20.9 \\
10.2\end{array}$ \\
\hline
\end{tabular}

\begin{tabular}{|c|c|c|c|c|c|c|}
\hline $\begin{array}{l}\text { Little Pittsburg } 3 \\
\text { Brushy Basin Member }\end{array}$ & A & Aerial__-_. & $\begin{array}{l}\mathbf{M} \\
\mathbf{U}\end{array}$ & $\begin{array}{l}5-1-57 \\
5-3-60\end{array}$ & $\begin{array}{l}\mathrm{GX}-57-1807 \\
\mathrm{GX}-60-3 \mathrm{~B}\end{array}$ & $\begin{array}{l}22.1 \\
21.5\end{array}$ \\
\hline
\end{tabular}

Cryptantha

\begin{tabular}{l|l|l|l|l|l|l|}
\hline Little Pittsburg 3................ & A & Aerial_............ & M & $5-1-57$ & GX-57-1805 & 28.2 \\
\hline
\end{tabular}

\begin{tabular}{|c|c|c|c|c|c|c|}
\hline Telluride 3, dump $\ldots . .$. & A & Aerial_. & M & $5-16-49$ & P6T & 14.0 \\
\hline Memphis Hill group. .......... & B & $\begin{array}{l}\text { Roots } \\
\text { Aerial }\end{array}$ & $\begin{array}{l}\mathrm{M} \\
\mathrm{M}\end{array}$ & 5- $-1-57$ & $\begin{array}{l}\text { F7R } \\
G X_{-57-1799}\end{array}$ & $\begin{array}{r}5.6 \\
36.0\end{array}$ \\
\hline On road to Yellow Cat Mesa & $\mathrm{C}$ & ... do... & U & $8-11-52$ & D-70690 & 9.8 \\
\hline $\begin{array}{l}\text { On Dewey Road, Cutler, Forma- } \\
\text { tion. }\end{array}$ & D & ............ & $\mathrm{U}$ & $5-2-57$ & $G X-57-1825$ & \\
\hline
\end{tabular}


soils collected in the Yellow Cat area, Grand County, Utah-Continued

\begin{tabular}{|c|c|c|c|c|c|c|c|c|c|c|}
\hline \multicolumn{2}{|c|}{ Uranium } & \multicolumn{2}{|c|}{ Vanadium } & \multicolumn{3}{|c|}{ Selenium } & \multicolumn{2}{|c|}{ Molybdenum } & \multicolumn{2}{|c|}{ Lead } \\
\hline $\begin{array}{l}\text { Plant } \\
\text { ash }\end{array}$ & Soil & $\begin{array}{c}\text { Plant } \\
\text { ash }\end{array}$ & Soil & $\begin{array}{c}\text { Plant } \\
\text { dry } \\
\text { weight }\end{array}$ & $\begin{array}{c}\text { Plant } \\
\text { ash }\end{array}$ & Soil & $\begin{array}{c}\text { Plant } \\
\text { ash }\end{array}$ & Soil & $\begin{array}{l}\text { Plant } \\
\text { ash }\end{array}$ & Soil \\
\hline
\end{tabular}

\section{pattersoni}

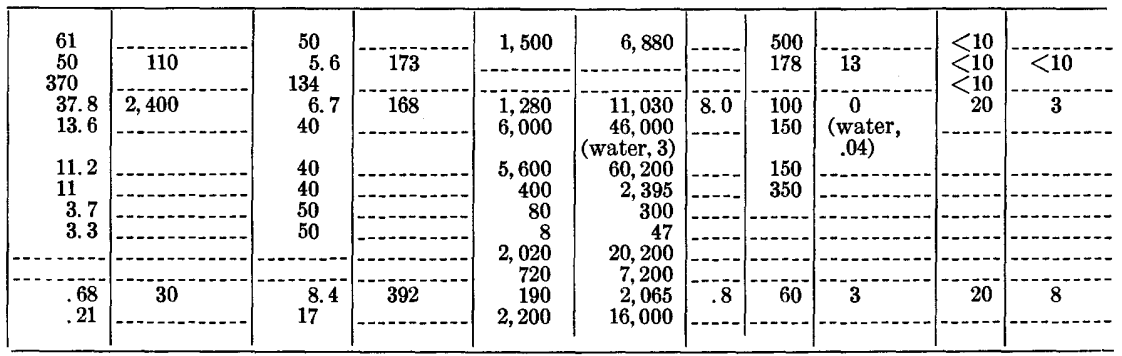

\section{preussi}

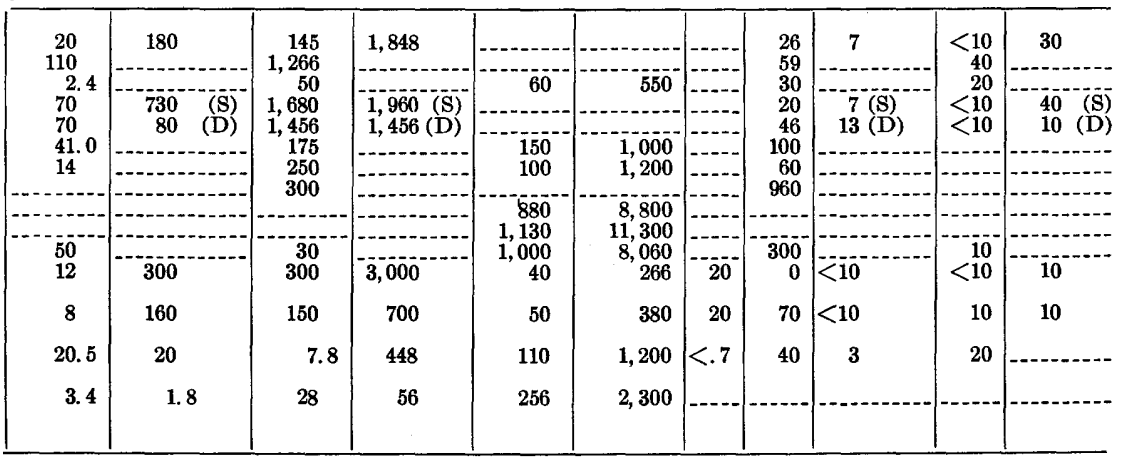

thompsonae

\begin{tabular}{|c|c|c|c|c|c|c|c|c|c|c|}
\hline 3.6 & - & 90 & $--2-2-2-2$ & 5 & 14 & $---\infty$ & 5 & & - & --- \\
\hline 7.2 & 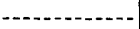 & 100 & 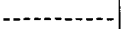 & 15 & 64 & $\ldots-$ & $<10$ & $\ldots$ & 20 & - \\
\hline
\end{tabular}

\section{nudicaulis}

\begin{tabular}{|c|c|c|c|c|c|c|c|c|c|c|}
\hline $\begin{array}{r}8 \\
20\end{array}$ & 3,070 & $\begin{array}{r}39 \\
100\end{array}$ & 100 & & & 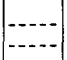 & $\begin{array}{l}7 \\
7\end{array}$ & $\begin{array}{c}7 \\
-\end{array}$ & $\begin{array}{l}<10 \\
<10\end{array}$ & $<10$ \\
\hline \multicolumn{11}{|c|}{ angustiflora } \\
\hline $\begin{array}{r}11.9 \\
2.5\end{array}$ & 100 & 30 & 30 & $\begin{array}{l}135 \\
275\end{array}$ & 1,280 & $\mid \begin{array}{c}\cdots \\
\cdots \cdots\end{array}$ & $\begin{array}{l}15 \\
30\end{array}$ & & $\begin{array}{l}15 \\
30\end{array}$ & \\
\hline
\end{tabular}

\section{fulvocanescens}

\begin{tabular}{|c|c|c|c|c|c|c|c|c|c|c|}
\hline 3.4 & 300 & $-\ldots . . .$. & $-1-\ldots+n \mid$ & & $\mid---1--\infty$ & $\ldots$ & 20 & - - & $<10$ & -- \\
\hline \multicolumn{11}{|l|}{ inflatum } \\
\hline \begin{tabular}{c}
10 \\
80 \\
\hdashline 3.2 \\
$<1$
\end{tabular} & \begin{tabular}{|c}
180 \\
-10
\end{tabular} & $\begin{array}{r}50 \\
560 \\
200 \\
40 \\
10\end{array}$ & \begin{tabular}{c}
1,848 \\
\\
\hdashline
\end{tabular} & 200 & $\mid \begin{array}{r}-2 \\
-26\end{array}$ & 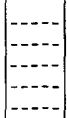 & $\begin{array}{l}13 \\
40 \\
10 \\
10 \\
30\end{array}$ & $\mid$\begin{tabular}{c}
7 \\
\hdashline-1 \\
-20
\end{tabular} & $\begin{array}{r}20 \\
70 \\
10 \\
-<---\end{array}$ & 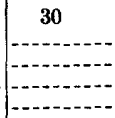 \\
\hline
\end{tabular}


TABLE 16.-Metal content, in parts per million, of plants and associated

\begin{tabular}{|c|c|c|c|c|c|c|}
\hline Source of sample & $\begin{array}{l}\text { Spec- } \\
\text { imen }\end{array}$ & $\begin{array}{l}\text { Part of plant } \\
\text { sampled }\end{array}$ & $\begin{array}{l}\text { Degree } \\
\text { of min- } \\
\text { eraliza- } \\
\text { tion }\end{array}$ & $\begin{array}{l}\text { Date of } \\
\text { collec- } \\
\text { tion }\end{array}$ & $\begin{array}{l}\text { Field or } \\
\text { laboratory } \\
\text { No. }\end{array}$ & $\begin{array}{l}\text { Ash, } \\
\text { in } \\
\text { per- } \\
\text { cent }\end{array}$ \\
\hline \multicolumn{7}{|c|}{ Grindelic } \\
\hline 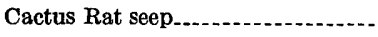 & A & Aerial & $\mathbf{M}$ & $8-11-52$ & D-70730 & 8.7 \\
\hline Schroeckingerite mine................ & $\mathbf{B}$ & Roots & $\begin{array}{l}\mathbf{M} \\
\mathbf{M}\end{array}$ & $\begin{array}{l}6-20-56 \\
-d o-.--\end{array}$ & $\begin{array}{l}G X-56-2308 \\
G X-56-2309\end{array}$ & $\begin{array}{l}8.7 \\
6.4\end{array}$ \\
\hline $\begin{array}{l}\text { Cactus Rat seep } \\
\text { Flattop traverse }\end{array}$ & $\begin{array}{l}\mathrm{C} \\
\mathrm{D}\end{array}$ & Aerial do....... & $\underset{\mathbf{U}}{\mathrm{M}}$ & $\begin{array}{l}8-51 \\
8-11-52\end{array}$ & $\begin{array}{l}\text { D }-53520 \\
D-70724\end{array}$ & 7.5 \\
\hline & $\underset{\mathrm{F}}{\mathbf{E}}$ & do & $\begin{array}{l}\check{U} \\
U\end{array}$ & -. do do.... & $\begin{array}{l}D-70728 \\
D-70698\end{array}$ & $\begin{array}{l}7.5 \\
6.3\end{array}$ \\
\hline
\end{tabular}

\begin{tabular}{|c|c|c|c|c|c|c|}
\hline \multicolumn{7}{|c|}{ Gutierrezia } \\
\hline $\begin{array}{l}100 \mathrm{ft} \text { south of Flattop } 1 \\
\text { In Flattop ore. } \\
\text { On Flattop traverse. }\end{array}$ & $\begin{array}{l}\mathrm{A} \\
\mathrm{B} \\
\mathbf{C}\end{array}$ & Aerial-1-. & $\begin{array}{l}\mathbf{M} \\
\mathbf{M} \\
\mathbf{M}\end{array}$ & 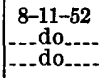 & $\begin{array}{l}\text { D-70703 } \\
\text { D-70701 } \\
\text { D-70721 }\end{array}$ & $\begin{array}{l}6.5 \\
5.3 \\
8.6\end{array}$ \\
\hline $\begin{array}{l}\text { Cactus Rat seep } \\
\text { Flattop traverse }\end{array}$ & $\underset{\mathbf{E}}{\mathbf{D}}$ & - & $\begin{array}{l}\mathbf{M} \\
\mathbf{U}\end{array}$ & -.do_.... & $\begin{array}{l}\text { D-70731 } \\
\text { D-70708 }\end{array}$ & $\begin{array}{l}6.3 \\
6.9\end{array}$ \\
\hline Mancos Shale & $\mathbf{F}$ & $\mid$ & $\begin{array}{l}\mathbf{U} \\
\mathbf{U}\end{array}$ & 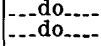 & $\begin{array}{l}\text { D-70720 } \\
\text { D-70687 }\end{array}$ & $\begin{array}{l}6.9 \\
5.7\end{array}$ \\
\hline
\end{tabular}

\begin{tabular}{|c|c|c|c|c|c|c|}
\hline Road south of Yellow Cat Mesa..... & $\mathbf{A}$ & Aerial. & $\mathbf{M}$ & $5-1-57$ & GX-57-1802 & 10.7 \\
\hline \multicolumn{7}{|c|}{ Lepidium } \\
\hline $\begin{array}{l}\text { Cactus Rat deposit } \\
\text { Brushy Basin Member }\end{array}$ & $\begin{array}{l}\mathbf{A} \\
\mathbf{B} \\
\mathbf{C}\end{array}$ & $\begin{array}{l}\text { Aerial } \\
\text { Roots } \\
\text { Aerial }\end{array}$ & $\begin{array}{l}\mathbf{M} \\
\mathbf{M} \\
\mathbf{M} \\
\mathbf{U}\end{array}$ & $\begin{array}{r}4-27-55 \\
6-20-56 \\
-4-30-57\end{array}$ & $\begin{array}{l}G X-55-1825 \\
G X-56-2310 \\
G X-56-2311 \\
G X-57-1792\end{array}$ & $\begin{array}{r}20.2 \\
8.5 \\
4.4 \\
20.3\end{array}$ \\
\hline
\end{tabular}

\begin{tabular}{l|l|l|l|l|l|l|}
\hline & \multicolumn{3}{r}{ Solidago } \\
\hline Little Pittsburg 3................. & A & Aerial_........... & M & $5-1-57$ & GX-57-1808 & 15.3 \\
\hline
\end{tabular}

Sphaeralcea

\begin{tabular}{|c|c|c|c|c|c|c|}
\hline Parko 23-2 & $\mathbf{A}$ & Aerial & $\mathbf{M}$ & $6-21-56$ & GX-56-2604 & $\begin{array}{r}9 \\
6\end{array}$ \\
\hline $\begin{array}{l}\text { McCoy group, Sta. } 2 \\
\text { Sandstone in Summerville Forma- }\end{array}$ & $\underset{\mathbf{C}}{\mathbf{B}}$ & Aerial & U & $\begin{array}{l}5-2-57 \\
5-9-57\end{array}$ & $\begin{array}{l}\mathrm{G}: \mathrm{X}-57-1819 \\
\mathrm{GX}-57-1824 \mathrm{a}\end{array}$ & $\begin{array}{l}19.5 \\
14.2\end{array}$ \\
\hline
\end{tabular}

\begin{tabular}{|c|c|c|c|c|c|c|}
\hline \multicolumn{7}{|c|}{ Stanleya } \\
\hline $\begin{array}{l}\text { At mines below Yellow Cat Mesa- } \\
\text { Mancos Shale. } \\
\text { Above McCoy group }\end{array}$ & $\begin{array}{l}\mathbf{A} \\
\mathbf{C}\end{array}$ & $\begin{array}{l}\text { Aerial } \\
\text { New growth } \\
\text { Old growth... }\end{array}$ & $\begin{array}{l}\mathbf{M} \\
\mathbf{U} \\
\mathbf{U} \\
\mathbf{U}\end{array}$ & $\begin{array}{c}5-1-57 \\
8-11-52 \\
5-2-57 \\
--d o-. .-\end{array}$ & $\begin{array}{l}\mathrm{GX}-57-1801 \\
\mathrm{D}-70689 \\
\mathrm{GX}-57-1821 \\
\mathrm{GX}-57-1822\end{array}$ & $\begin{array}{r}16.1 \\
6.9 \\
18.3 \\
3.2\end{array}$ \\
\hline \multicolumn{7}{|c|}{$\overline{\text { Townsendia }}$} \\
\hline McCoy group....... & $\begin{array}{l}\mathbf{A} \\
\mathbf{B}\end{array}$ & Aerial-a. & $\begin{array}{l}\mathbf{M} \\
\mathbf{M}\end{array}$ & $\begin{array}{l}6-20-56 \\
5-2-57\end{array}$ & $\begin{array}{l}G X-56-1029 \\
G X-57-1813\end{array}$ & 39.4 \\
\hline \multicolumn{7}{|c|}{ Zygadenus } \\
\hline Cactus Rat deposit...... & $\stackrel{\mathbf{A}}{\mathbf{B}}$ & Entire & $\begin{array}{l}\mathbf{M} \\
\mathbf{M}\end{array}$ & $\begin{array}{l}5-27-52 \\
4-30-57\end{array}$ & $\begin{array}{l}\mathrm{GX}-5222 \\
\mathrm{GX}-57-1796\end{array}$ & 21.7 \\
\hline \multicolumn{7}{|r|}{ Algae } \\
\hline Yellow Cat Campsite Spring & $\mathbf{A}$ & Entire............. & $\mathbf{M}$ & $4-8-56$ & $\mathrm{GX}-56-1030$ & \\
\hline
\end{tabular}


soils collected in the Yellow Cat area, Grand County, Utah-Continued

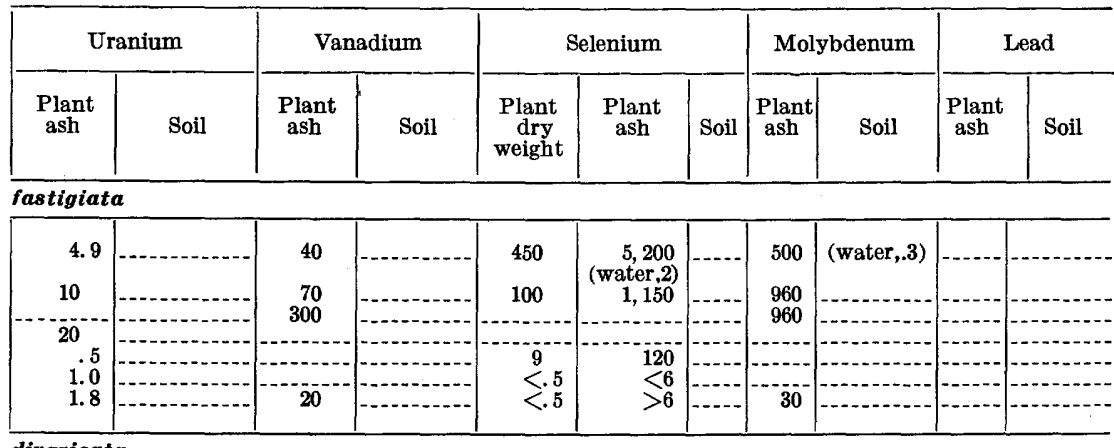

\section{divaricata}

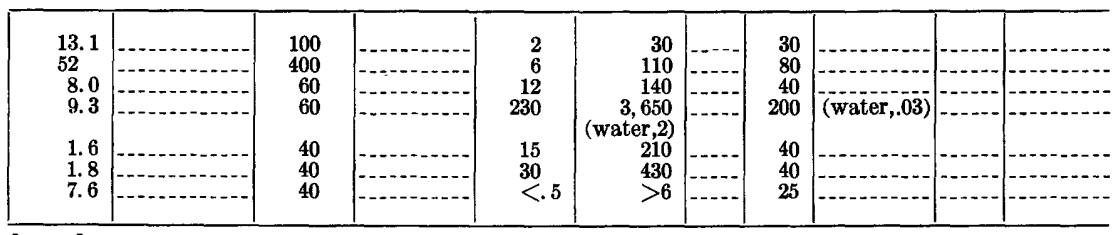

\section{boreale}

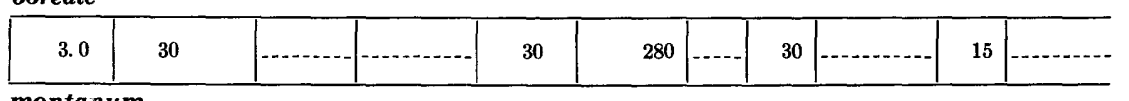

\section{montanum}

\begin{tabular}{|c|c|c|c|c|c|c|c|c|c|c|}
\hline $\begin{array}{r}9.0 \\
7 \\
76 \\
1.9\end{array}$ & 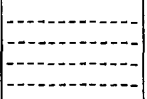 & $\begin{array}{r}40 \\
70 \\
600 \\
30\end{array}$ & 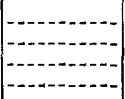 & 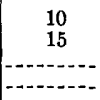 & $\begin{array}{r}50 \\
176 \\
\hdashline-10 \\
\hdashline\end{array}$ & $\left|\begin{array}{c|}-\cdots \\
-\cdots- \\
-\cdots- \\
-\cdots-\end{array}\right|$ & $\begin{array}{r}80 \\
120 \\
120 \\
15\end{array}$ & 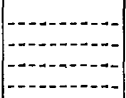 & - & 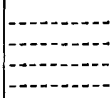 \\
\hline
\end{tabular}

\begin{tabular}{|r|r|r|r|r|r|r|r|r|r|}
\hline 10.3 & 70 & $\ldots \ldots \ldots$ & 80 & 520 & $\ldots \ldots$ & 15 & $\ldots \ldots \ldots$ & 15 & $\ldots \ldots \ldots$ \\
\hline
\end{tabular}

\section{parviflora}

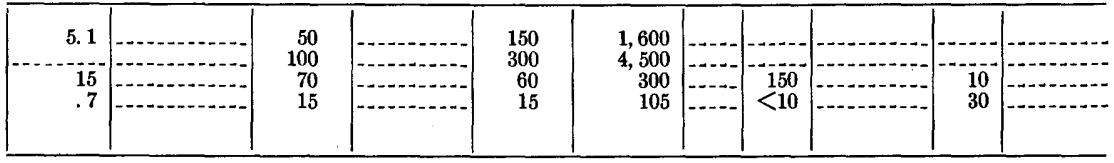

\section{pinnata}

\begin{tabular}{|c|c|c|c|c|c|c|c|c|c|c|}
\hline $\begin{array}{r}2.5 \\
4.9 \\
.5 \\
2.3\end{array}$ & 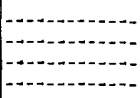 & $\begin{array}{r}20 \\
20 \\
<10 \\
50\end{array}$ & 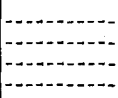 & $\begin{array}{r}500 \\
85 \\
200 \\
80\end{array}$ & $\begin{array}{r}3,105 \\
1,230 \\
1,090 \\
250\end{array}$ & 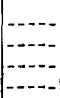 & $\begin{array}{l}70 \\
30 \\
30 \\
20\end{array}$ & 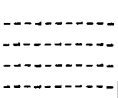 & $\begin{array}{r}<10 \\
<10 \\
30\end{array}$ & 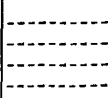 \\
\hline
\end{tabular}

\section{incana}

\begin{tabular}{|c|c|c|c|c|c|c|c|c|c|c|}
\hline $\begin{array}{l}7 \\
.7\end{array}$ & | & 50 & 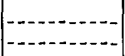 & 600 & - & $\mid--\overline{-}$ & 500 & 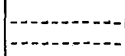 & $-2<10$ & (-) \\
\hline
\end{tabular}

\begin{tabular}{|c|c|c|c|c|c|c|c|c|c|c|}
\hline 1.5 & 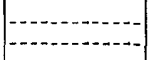 & 30 & 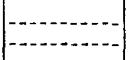 & $\begin{array}{r}110 \\
20\end{array}$ & $\begin{array}{r}1,100 \\
90\end{array}$ & $-\cdots$ & $<--\infty$ & 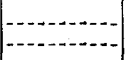 & 10 & 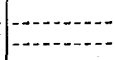 \\
\hline
\end{tabular}

\section{(Spirogya sp.)}

\begin{tabular}{l}
\hline (Spirogya sp.) \\
\begin{tabular}{|r|r|r|r|r|} 
&
\end{tabular} \mid $\begin{array}{r}\text { (water, } \\
1)\end{array}$ \\
\hline
\end{tabular}


TABLE 17.-Comparison of four metals in the ash of plants from mineralized and unmineralized areas

[ppm, parts per million; $\mathrm{m} / \mathrm{u}$, mineralized to unmineralized ratio]

\begin{tabular}{|c|c|c|c|c|c|c|c|c|}
\hline \multirow{2}{*}{ Classes of vegetation } & \multicolumn{2}{|c|}{ Uranium } & \multicolumn{2}{|c|}{ Vanadium } & \multicolumn{2}{|c|}{ Molybdenum } & \multicolumn{2}{|c|}{ Lead } \\
\hline & $\begin{array}{l}\text { Mean } \\
(\mathrm{ppm})\end{array}$ & $\begin{array}{l}\text { Ratio } \\
(\mathrm{m} / \mathrm{u})\end{array}$ & $\underset{(\mathrm{ppm})}{\text { Mean }}$ & $\begin{array}{l}\text { Ratio } \\
(\mathrm{m} / \mathrm{u})\end{array}$ & $\underset{(\mathrm{ppm})}{\text { Mean }}$ & $\begin{array}{l}\text { Ratio } \\
(\mathrm{m} / \mathrm{u})\end{array}$ & $\begin{array}{l}\text { Mean } \\
\text { (ppm) }\end{array}$ & $\begin{array}{l}\text { Ratio } \\
(\mathrm{m} / \mathrm{u})\end{array}$ \\
\hline $\begin{array}{l}\text { Grasses: } \\
\text { Unmineralized.- } \\
\text { Mineralized }\end{array}$ & $\begin{array}{r}4 . \\
34\end{array}$ & $\ldots$ & $\begin{array}{r}25 \\
135\end{array}$ & & $\begin{array}{l}16 \\
32\end{array}$ & & $<10$ & \\
\hline $\begin{array}{l}\text { Ratio } \\
\text { Other herbs (in- } \\
\text { cluding Selenium } \\
\text { indicators): }\end{array}$ & 34 & 8.5 & 135 & 5.4 & 32 & 2 & 10 & $1+$ \\
\hline $\begin{array}{l}\text { Unmineralized } \\
\text { Mineralized }\end{array}$ & ${ }_{21}^{1.9}$ & & $\begin{array}{l}35.6 \\
191\end{array}$ & & $\begin{array}{l}41.2 \\
155\end{array}$ & & $\begin{array}{l}18.1 \\
14\end{array}$ & -1 \\
\hline $\begin{array}{l}\text { Ratio } \\
\text { Trees and shrubs: }\end{array}$ & & $1 \overline{1}$ & - & 5.4 & & 3.8 & & \\
\hline $\begin{array}{l}\text { Unmineralized } \\
\text { Mineralized }\end{array}$ & 8. 7 & & $\begin{array}{l}19.8 \\
51\end{array}$ & & $\begin{array}{l}\text { 14. } 2 \\
\text { 36. } 5\end{array}$ & & $\begin{array}{l}17 \\
29\end{array}$ & $\cdots-1$ \\
\hline Ratio. & $\ldots$ & 9.8 & $\ldots \ldots$ & 2. 6 & & 2.6 & & 1. 7 \\
\hline
\end{tabular}

1 Ratio of metal content of plants growing on mineralized ground to that of plants growing on unmineralized ground.

TABLE 18.-Ratio of metals in near-surface roots to metals in aerial parts of the plant

\begin{tabular}{|c|c|c|c|}
\hline & $\begin{array}{l}\text { Uranium } \\
\text { (roots/ } \\
\text { tops) }\end{array}$ & $\begin{array}{l}\text { Vanadium } \\
\text { (roots/ } \\
\text { tops) }\end{array}$ & $\begin{array}{c}\text { Molybde- } \\
\text { num } \\
\text { (roots/ } \\
\text { tops) }\end{array}$ \\
\hline $\begin{array}{l}\text { Grasses } \\
\text { Woody plants } \\
\text { Other herbs }\end{array}$ & $\begin{array}{l}2 \\
3 \\
4\end{array}$ & $\begin{array}{l}12 \\
2 \\
1.3\end{array}$ & $\begin{array}{l}0.35 \\
3\end{array}$ \\
\hline
\end{tabular}

URANIUM AND DAUGHTER PRODUCTS

ANOMALOUS GROWTH EFFECTS

To consider the effects of the element uranium on plants separately from the effects produced by radiation from the decay products is difficult, but perhaps no separation is necessary. The first report on the effects of uranium on higher plants was made by Loew (1902), who reported that uranium salts have a stimulating effect on plants. Similarly, Stoklasa and Penkava (1928), Drobkov (1937, 1940, 1951), Bevilotti (1945), Becquerel and Rousseau (1947), Favilli (1948), and Krog, ${ }^{1}$ reported that low levels of uranium concentration in nutrient solutions stimulated plant growth. Stoklasa and Penkava found the optimum concentration for maximum growth to be 2.8-4.2 ppm uranium nitrate or 1.3-2.0 ppm uranium. They also found that

\footnotetext{
${ }^{1}$ Krog N. E., 1952. The effects of uranium salts on higher plants: Minnesota Univ. unpub. Ph. D. thesis, $51 \mathrm{p}$.
} 
uranium nitrate at optimum levels increased the rate of transpiration and photosynthesis and the assimilation of phosphorus and iron. Drobkov (1951) grew plants using purified reagents and distilled water to show that uranium is essential for normal growth and for the development of flower buds. He found that uranium absorption was greatest at the time of flowering and that additions of uranium produced an increase in seed production, earlier maturation, and an increase in carbohydrates. Probably, though, as stated by Krog, uranium is not essential for plant life but acts as an accessory micronutrient in plant nutrition. Becquerel and Rousseau (1947) reported that additions of uranyl sulfate advanced the maturing of cereals by more than 1 week. A similar shortening of fruiting time for tomatoes was observed by Gleditsch and Graf (1942). Baranov (1939) reported increases of as much as two orders of magnitude in the uranium content of roots of plants. Unfavorable effects at high concentrations, on the other hand, were observed by Voelcker (1923), Stoklasa and Penkava (1928), Bambacioni-Mezzetti (1934), and Krog. (See footnote 1.) Microscopic studies by Acqua $(1912,1913)$ showed that a checking of cell division in the roots was due to a deposit of oxidized yellow material in the cell nuclei of the meristem tissue. Blume, Hagen, and Mackie (1950) also found that radiation injury interfered with cell division in the meristematic regions.

The effects of uranium as a nutrient cannot easily be separated from those of uranium as a source of radioactivity. Although uranium in itself is not markedly radioactive, the highly radioactive daughter products produced within the plant and taken up from the soil as a result of decay are sufficient to affect the plant. This I was able to show in experimental plot studies by producing the same results with both carnotite and thorium ore. Irradiation from a tubed radiation source produced the same effect as reported for uranium in nutrient solution by Stoklasa and Penkava (1928) and Drobkov (1937, 1940, 1951). Probably the first work on the effect of radiation on plants was a very careful study made from 1905 to 1907 by C. S. Gager of the New York Botanical Garden. He (1907, p. 264) found a stimulation, acceleration, retardation, or inhibition of either germination, growth, respiration, fermentation, cell division, or starch formation, depending on the strength of salt used, distance from source, duration, presence of intervening screens, nature of tissue, and species of plant. By irradiating the pollen and the ovary, Gager was able to produce mutants. He (1908, p. 194) reported that plants were stimulated and that respiration was accelerated at low radiation intensities. No starch was formed, and synthesis of carbohydrates was hindered in the plants closest to the source. At high intensities (Gager, 1908, p. 229), cell division ceased, size of cells decreased, and 
tissue differentiation accelerated, which contributed to an early senescence. Petri $(1929,1930)$ found that radiation from $\mathrm{UO}_{2}$ and $\mathrm{U}_{3} \mathrm{O}_{8}$ caused a reduction in growth and limited the absorption of water by live trees to 50 percent. The conditions described by Gager were confirmed by Verducci (1945) and Gunckel (1956). Gunckel described changes in plant parts such as reduction in length, localized swellings, and adventitious buds on the stems; blade thickening and changes in form and structure of the leaves; and changes in form and number of flower parts, particularly in petals and stamens of flowers.

Recent studies undertaken at the Brookhaven Institute as part of an Atomic Energy Commission program have produced some very significant results. Plants are being grown under outdoor conditions in concentric rings around a cobalt-60 gamma-radiation source of $15,000 \mathrm{r}$ per day (roentgens per day). The most tolerant plants, gladiolas and sedums, are unaffected in an area receiving 5,000 r per day; the least tolerant plants, the gymnosperms, are killed in an area receiving $20-25 \mathrm{r}$ per day. Low-intensity gamma radiation $(2.2 \mathrm{r}$ per day) produced somatic mutations on the petals of snapdragons (Sparrow and Pond, 1956). The size of the mutant spots varied from single cells to whole flowers. Radiation from the cobalt-60 source also increased the number of tumors from 0.1 to 53 percent of the fresh weight of Nicotiana plants. The same effect was produced by internal feeding of phosphorus-32. The tumors put out leaves of their own and continued to grow after the host plant was dead. Nilan (1956) reported that radiation of seeds can produce chromosome aberrations, sterility, genetic mutations, and cblorophyl deficiency in the seedlings. The results, however, were affected by species, stage of cellular development, age of tissue, chromosome number, chromosome size, moisture, temperature, and atmosphere. Those seeds that had the lowest number of chromosomes and the most chromosome activity were most sensitive to radiation. The water and oxygen contents are significant as irradiation produces ionization to $\mathrm{HO}_{2}, \mathrm{H}$, and $\mathrm{OH}$, which are harmful to cells. The total dose fatal to the various plant species ranges from 7,500 to $90,000 \mathrm{r}$ (roentgens).

Although the amounts of radiation used at Brookhaven are large compared with those measured above ground in the Yellow Cat area, the radiation constantly received by plants rooted in carnotite ore may be sufficient to affect the plants.

Anomalous growth changes observed in plants rooted in carnotite, then, may be due to radiation rather than to uranium as a bioelement. The changes observed on mine dumps and around oxidized deposits include decayed and fragmental roots, early maturation, senescence, and reduction in length of internodes resulting in dwarfing and, in some plants, frenching. Plants grown from seed in experimental car- 
notite soils developed a basal rosette of enlarged leaves on a raised stalk in Grindelia and abortive petals and stamens in Stanleya. As the differences described were noted only in areas of unusually great oxidation, abnormal growth effects were not used at Yellow Cat as a guide in prospecting.

\section{TOLERANCE}

Species vary widely in their tolerance of mineralized ground and in their susceptibility to injury. In botanical prospecting, tolerance of the various species to the entire complex environment of the carnotite ore deposit is of greatest importance, and, therefore, little attempt was made to isolate the various components affecting the makeup of the uranophile plant society. The minor changes in the availability of both macro and microplant nutrients near an ore body create a flora, or a biogeochemical province (Vinogradova and Drobkov, 1949) of potential use as a guide in prospecting. The additional effect of radiation, however, on the various species must also be considered. At Nagasaki and Hiroshima, for example, Japanese pine was killed within 6,500 feet of ground zero, while camphor, cherry, and plum trees within the same radius were stimulated to send out new shoots (Jornlin, 1948). Takeo Furuno, Nagasaki prefectural agricultural expert, reported in the press (Sept. 24,1946$)$ that summer crops following the bombing had shown increases of from 50 to 300 percent over the normal yield. The wheat crop was twice the normal yield, and the cotton crop was three times the average yield. Sweet potatoes were ready for harvesting much earlier than usual. Pumpkins, sugarbeets, tomatoes, eggplants, and similar plants showed a 50-percent crop increase; rice and lentils, on the other hand, failed to mature. Some pumpkins showed this strange development-the skin developed into a leaf, then a bud, and finally became a second pumpkin. A newspaper account (The Washington Post, Oct. 13, 1946) had the following description of the immediate bombed area:

The bomb had not only left the underground organs of plants intact, it had stimulated them. Everywhere were bluets and Spanish bayonets, goosefoot, morning glories, and day lilies, the hairy-fruited bean, purslane, clotbur, and sesame, and panic grass, and feverfew. Especially in a circle at the center, sickle senna grew in extraordinary regeneration.

The species of plants that are most tolerant of irradiated ground at the Nevada Test Site and that have invaded the denuded ground during the years since the 1957 series of detonations have been described by Shields and Wells (1962) and observed more recently by me. An original natural flora consisted mainly of the shrubs, Grayia spinosa (hopsage), Coleogyne ramosissima, Atriplex canescens, and of Joshua trees. The shots resulted in complete denudation of 
vegetation for a radius of 0.5 mile because of the intense heat and blast effects.

Within a year following the last detonation, Salsola (Russian thistle) had invaded the ground-zero area. At the present time, Birdsnest Eriogonum also grows in the ground zero area. The annuals, Mentzelia albicaulis and Erodium cicutarium, came up within 0.1 to 0.3 mile of ground zero at the shot; these now grow in a society with Oryzopsis hymenoides (ricegrass), Sphaeralcea (globemallow), Astragalus lentiginosus, and Hymenoclea (burrobush). The nearest shrubs are still 3,200 to 3,700 feet from ground zero.

Other significant comparisons can be made between the tolerance of species noted at Hiroshima and at the Nevada Test Site and the species noted at radioactive areas near the cobalt-60 source at Brookhaven and at the Yellow Cat deposits. The high tolerance of Chenopods, for instance, has been noted in all four places; the high tolerance of Mentzelia albicaulis and of species of Astragalus, Lepidium, Aster, Eriogonum, Sphaeralcea, Mirabilis, Stipa, Oryzopsis, Yucca, Portulaca, and Chrysanthemum has been observed in both types of environment. Possibly the stimulation of their growth is caused by radiation.

Nilan (1956, p. 152), in describing the work at Brookhaven, reported that members of the Chenopodiaceae (as goosefoot), Portulacaceae (as purslane), and Cruciferae are highly resistant to radioactivity and that the Pinaceae, Solanaceae, Scrophulariaceae, and Carduaceae (not listed in the Hiroshima description) are highly sensitive. Sparrow and Singleton (1953) showed that, as extremes of tolerance, Tradescentia paludosa was severely affected by $30 \mathrm{r}$ daily whereas gladiolas were relatively unaffected by $2,000 \mathrm{r}$ daily for 42 days.

In plot experiments run concurrently with the Yellow Cat project, the composite Grindelia was found to be the most tolerant of uraniferous ground. Seeds were germinated and plants were grown in a mixture of sand and carnotite ore that averaged $2,500 \mathrm{ppm}$ uranium. The Astragalus genus, which requires selenium, is also very tolerant of mineralized ground; and many species grow in radioactive areas, perhaps because selenium salts are more soluble in a carnotite environment.

The plant society that grows on mineralized ground was determined by taxonomic study of 13 mineralized and 11 unmineralized areas. In each area, complete collections were made from a strip of ground 5 feet wide and 10 feet long - the approximate size of the small known ore bodies exposed in the district. In each mineralized locality, the ore-bearing sandstone was not more than 15 feet beneath the surface; the nonmineralized areas were marked off along an outcrop of the 
same sandstone unit under similar slope, exposure, and moisture conditions. Actually these areas were not completely unmineralized, but they represented the degree of geochemical contrast needed for prospecting in the district. A compilation of these data is given in table 19.

TABLE 19.-Tolerance of common plants to uranium ores in Yellow Cat area

[Results of a study of 24 selected sites]

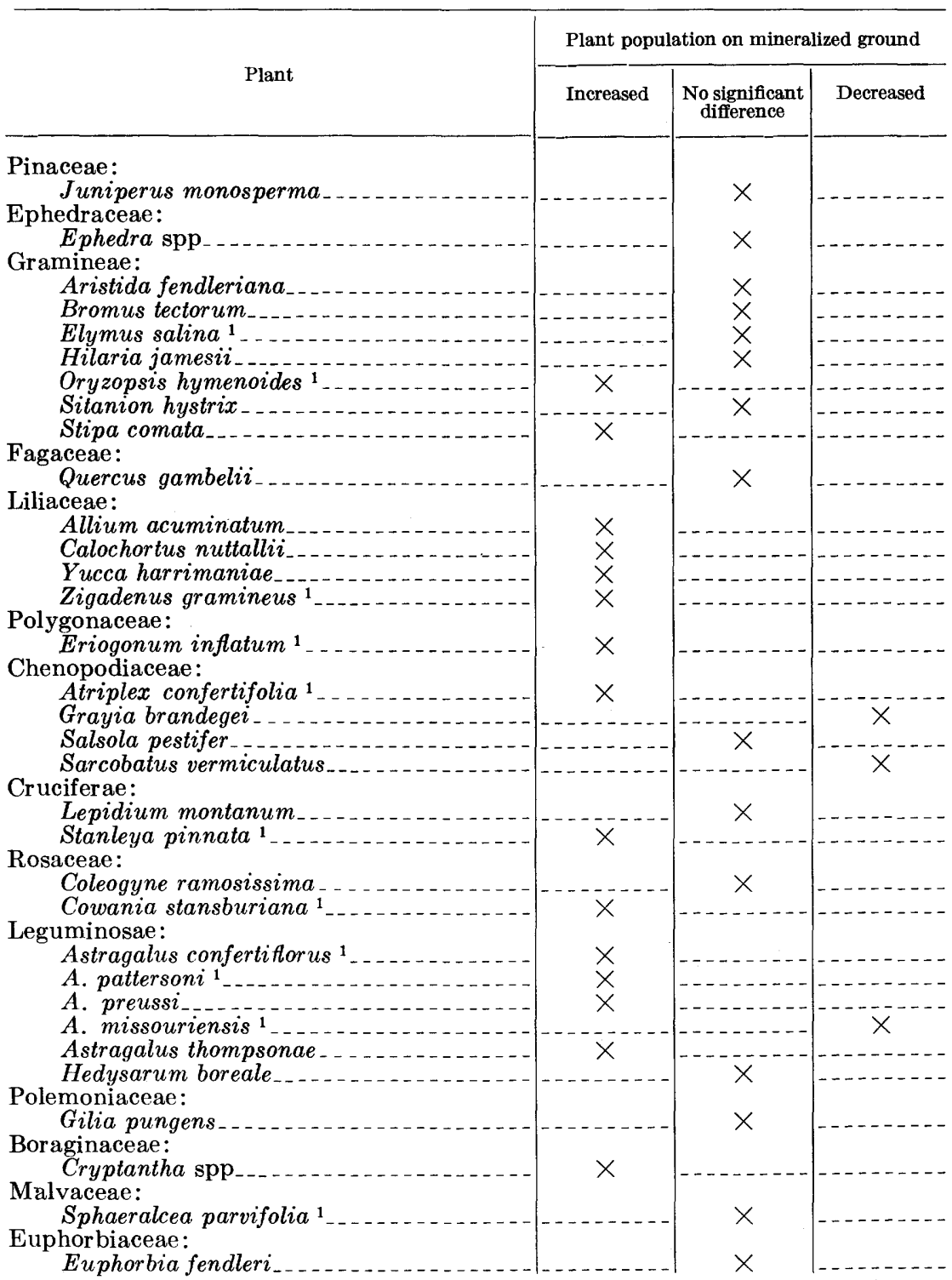

${ }^{1}$ Samples of these plants contained $>50 \mathrm{ppm}$ selenium dry weight. 
TABLE 19.-Tolerance of common plants to uranium ores in Yellow Cat area-Con. [Results of a study of 24 selected sites]

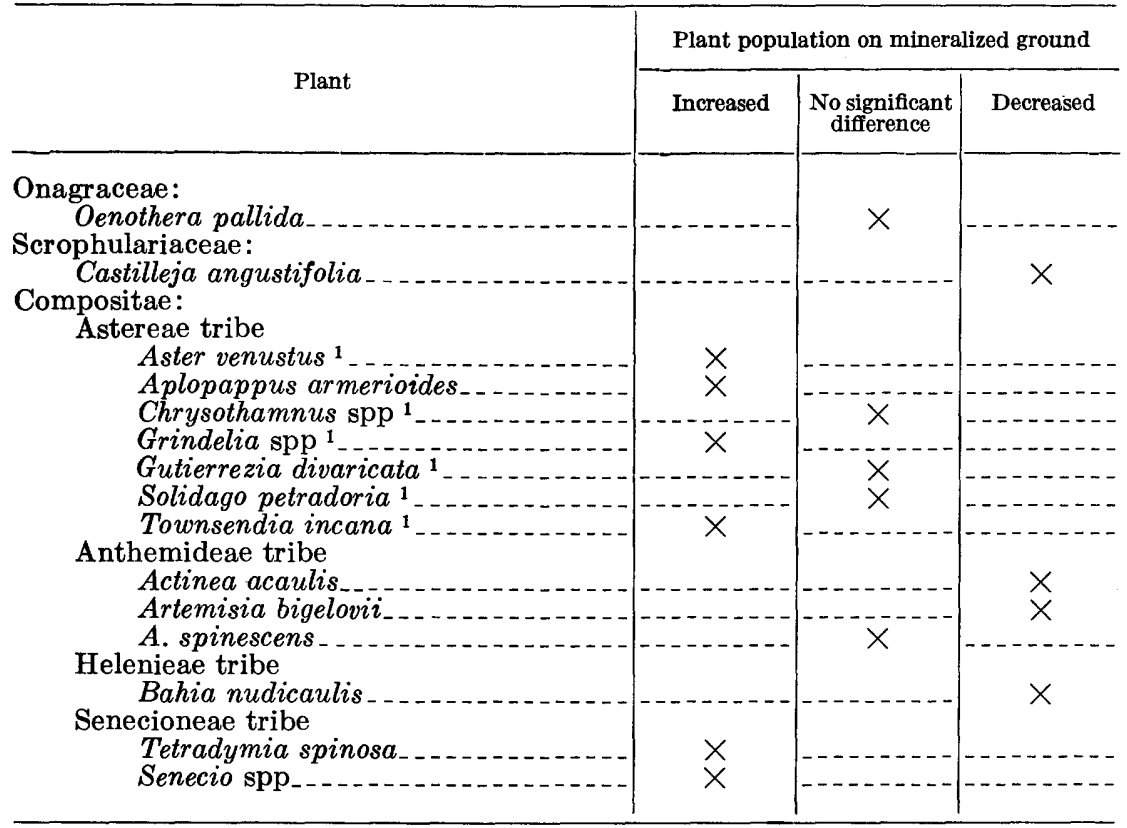

1 Samples of these plants contained $>50 \mathrm{ppm}$ selenium dry weight.

Species of Mirabilis and Mentzelia albicaulis are closely associated with mineralized ground in other districts. Russianthistle appears on most all disturbed ground, radioactive or not.

Thus the species that are tolerant of mineralized ground on the Colorado Plateau belong to the grass, lily, buckwheat, four-o'clock, mustard, rose, goosefoot, and legume families; within the large Compositae family the species are restricted to the Senecioneae and Astereae tribes. These families compare closely with those (discussed in previous paragraphs) which other workers found to be tolerant of radioactive ground. Castilleja, of the Scrophulariaceae that were found to be radiosensitive at Brookhaven, and Grayia spinosa, as at the Nevada Test Site react negatively. Because of the close agreement between the distribution of plant species on mineralized ground in Yellow Cat and known radioresistant and radiosensitive plant groups, the radioactivity of the uranium ores in the Yellow Cat area is believed to influence the development of the plant society that grows on the deposits.

\section{ACCUMULATION OF URANIUM}

The accumulation of uranium by plants was not reported until about 1940 when an adequate analytical method was developed in 
Germany. Hoffmann $(1942,1943)$ described a method by which plant ash was treated with sodium fluoride and the uranium was measured by fluorescence. By this method he obtained uranium contents of about $5.5 \mathrm{ppm}$ in the ash of plants growing in volcanic soils. $\mathrm{He}$ reported an extraordinary amount of $2,800 \mathrm{ppm}$ in a grape seed. Lexow, Maneschi, and Sa (1948) studied the uranium content of various plants and animals of Argentina. They found unusual concentrations of uranium in Larrea divaricata (creosote bush) and in Schinopsis lorentzii of the Apocynaceae. R. E. Gilbert (written communication, 1954) investigated the uranium content of vegetation in the Marysvale area, Utah. Because of the contamination in the area, he collected peeled 6 -8-inch stem samples. He found the following variations:

Uranium content of vegetation, Marysvale area, Utah

\begin{tabular}{r|r|r|r}
\hline & $\begin{array}{r}\text { Unmineralized } \\
(\mathrm{ppm})\end{array}$ & $\begin{array}{r}\text { Mineralized } \\
(\mathrm{ppm})\end{array}$ & $\begin{array}{c}\text { Mineralized/ } \\
\text { unmineralized }\end{array}$ \\
\hline Sagebrush & 1.7 & 9.7 & 5.7 \\
Juniper & 1.6 & 5.2 & 3.2 \\
Pinyon & 2.1 & 2.2 & 1.05 \\
\hline
\end{tabular}

These concentrations are higher for juniper and lower for pinyon than average values obtained near carnotite deposits on the Colorado Plateau.

Debnam (1954) investigated the use of plants as a guide in prospecting in Australia and reported that Xanthostemon paradoxus is a uranium accumulator. He found $0.20 \mathrm{ppm}$ uranium in the dry weight of the root, $0.34 \mathrm{ppm}$ in the twig, $0.1 \mathrm{ppm}$ in the bark, $0.16 \mathrm{ppm}$ in the sapwood, $0.25 \mathrm{ppm}$ in the heartwood, and $4.2 \mathrm{ppm}$ in the leaf. $\mathrm{He}$ generalized from four root analyses that uranium is not accumulated in the roots of plants. He collected these samples, however, in definitely contaminated areas. His results show (p. 13, table 8) that washing the Xanthostemon leaf samples lowered the uranium values appreciably and that most samples had about the same uranium content as the other plant species.

The accumulation of uranium by various plant species in the Yellow Cat area was investigated in a search for dependable species useful in prospecting by plant analysis. The tops of herbaceous plants were cut off at least 2 inches above the ground, and those collected in areas of active mining were washed in order to avoid dust and soil contamination. The roots also were washed, and many of them were peeled to avoid all possibility of soil contamination. As there is longitudinal passage of inorganic salts from the roots on one side of a tree to the limbs on the same side of the tree, the content of 
the leaves can vary greatly from one side to the other, depending on the location of mineralized ground. For this reason, leaves and end branches were always collected from the entire circumference of the tree and at the same height from the ground. For example, end branches of juniper collected from four sides of a tree contained 0.51, $0.29,0.53$, and $3.20 \mathrm{ppm}$ uranium; the roots on the side of the tree containing $3.20 \mathrm{ppm}$ extended into ore.

The plant material was first analyzed by a direct fluorimetric method developed by Grimaldi, May, and Fletcher (1952) and by Grimaldi and others (1954). Using the instrument described by Fletcher and Warner (1953) and by Kinser (1954), the limit of detection is about $1 \times 10^{-9} \mathrm{~g}$ uranium. Later the method was modified to eliminate interference from other elements, particularly manganese, that quenched the fluorescence. The method, as evolved, was described in detail by Huffman and Riley (1956). A statistical study made by Huffman and Riley of the precision of 319 pairs of determinations of sagebrush, pinyon, ponderosa pine, and juniper samples showed that the standard deviation varied not with the species but with the uranium content. The deviation ranged from $0.14 \mathrm{ppm}$ for samples containing $0.54 \mathrm{ppm}$ uranium to $2.26 \mathrm{ppm}$ for samples containing 34.77 ppm uranium. The expected standard deviation for any known uranium concentration can be calculated from the following formula:

$$
\text { Standard deviation }=0.15+0.063 \mathrm{U} \text {, }
$$

where U represents the amount of uranium found.

A lower limit of sensitivity of $0.3 \mathrm{ppm}$ in plant ash is possible using this method.

A field test sensitive to $1 \mathrm{ppm}$ and much less expensive to operate than the method just described has been devised since the Yellow Cat study was made. This test may be useful as a screening process in prospecting (A. P. Marranzino and F. N. Ward, written communication, 1960).

Analyses of many of the plants are shown in table 16. The plants that are rooted in mineralized ground and whose average uranium content is more than $10 \mathrm{ppm}$ are listed in table 20 . The largest concentrations of uranium in several species were found in plants collected from a small schroeckingerite deposit in the McCoy group. These species included:

$\begin{gathered}\text { Species } \\ \text { Uranium } \\ p p m\end{gathered}$
$\begin{aligned} & \text { Atriplex confertifolia } \\ & \text { Ephedra viridis_... }\end{aligned}$
Astragalus pattersoni
A. preussi


TABLE 20.-Uranium accumulator plants of the Yellow Cat area

\begin{tabular}{|c|c|c|c|}
\hline \multirow{2}{*}{ Plant species } & \multicolumn{2}{|c|}{$\begin{array}{l}\text { A verage uranium content in } \\
\text { ash, in parts per million }\end{array}$} & \multirow{2}{*}{$\begin{array}{l}\text { Coneentration } \\
\text { ratio } \\
\text { mineralized/ } \\
\text { unmineralized }\end{array}$} \\
\hline & $\begin{array}{l}\text { Mineralized } \\
\text { ground }\end{array}$ & $\underset{\text { ground }}{\text { Unmineralized }}$ & \\
\hline Allium macropetalum (wild onion) & 200 & & \\
\hline Algae, Spirogyra sp & 54 & & \\
\hline Chrysothamnus viscidiflorus (rabbitbrush) & 53 & 1.5 & 36 \\
\hline Oryzopsis hymenoides (ricegrass) & 38 & 4. 1 & \\
\hline Astragalus pattersoni (Patterson's loco) & 29 & .5 & 58 \\
\hline Ephedra viridis (Mormon tea) & 27 & 1.0 & 27 \\
\hline Astragalus preussi (Preuss' loco) & 26 & & \\
\hline Atriplex confertifolia (shadscale saltbush) & 22 & .8 & 28 \\
\hline Artemisia bigelovii (sagebrush) & 20 & 2. 0 & 10 \\
\hline Gutierrezia divaricata (snakeweed) & 20 & 1. 7 & 12 \\
\hline Cowania stansburiana (cliffrose) & 14 & .3 & 46 \\
\hline Quercus gambelii (scrub oak) _... & 14 & .5 & \\
\hline Tamarix gallica (tamarisk) $\ldots$ & 13 & .9 & 14 \\
\hline Grindelia fastigiata (gumweed) & 11 & 1.1 & 10 \\
\hline
\end{tabular}

In general, these accumulator species are more vigorous and more widely distributed on mineralized ground (see table 19); they also accumulate large amounts of selenium. Their absorption of elements, on the other hand, is variable; so the species are not as dependable for traverse sampling as are juniper and the xerophytic shadscale. Furthermore, the herbaceous indicator plants are spottily distributed whereas the juniper cover is evenly distributed on sandstone where ground water is available within 50 feet of the surface. The xerophytic shadscale is ubiquitous in the drier areas. Shadscale and juniper rooted in unmineralized ground seldom contain more than $1 \mathrm{ppm}$ uranium, whereas plants rooted in uranium-bearing rock commonly contain $2 \mathrm{ppm}$ or more.

Analyses of samples collected in different months of the summer from the same trees suggest that during the growing season the uranium content probably rises in some evergreen species but falls in most deciduous species. This difference for the most part can be ignored in day-to-day traverses, but it must be considered in resampling in anomalous areas.

Most species contain more uranium in their roots than in their tops, but the plants that are known to contain only small amounts of uranium in the tops may contain very large amounts in the roots if the uranium has been absorbed and accumulated there; other plants do not absorb much uranium even when it is available. This accumulation in the roots of species that do not seem, from the analysis of tops, to absorb a particular metal is commonly ignored by investigators. To discover whether the uranium which occurs in such large quantities in the roots was taken into the interior cells of the 
root or merely adsorbed to the root surface, roots were dug from the mine faces and then peeled to eliminate all surface contamination. The contents of both uranium and vanadium (table 16) were greater in the woody part of the root than in the peeled bark. The data compiled in table 21 further demonstrate that uranium in juniper

TABLE 21.-Concentration of uranium, in parts per million, in soils and in ash of aerial parts and roots of deep-rooted woody plants

[Analysts: Ruth Kreher, Jesse Greene, and Norma Guttag. Laboratory or field numbers are given in table 16]

\begin{tabular}{|c|c|c|c|c|c|c|c|}
\hline Plant and description & $\begin{array}{c}\text { Date of } \\
\text { collection } \\
(1949)\end{array}$ & $\underset{\text { tips }}{\text { Branch }}$ & Berries & $\begin{array}{l}\text { Near- } \\
\text { surface } \\
\text { roots }\end{array}$ & $\underset{\substack{\text { Surface } \\
\text { soil }}}{ }$ & $\begin{array}{l}\text { Roots } \\
\text { in ore }\end{array}$ & $\begin{array}{l}\text { Soil at } \\
\text { depth }\end{array}$ \\
\hline Juniperus, roots in ore at $4 \mathrm{ft}$ & May 18 & 2.0 & 1.0 & 8.0 & 9.3 & & \\
\hline $\begin{array}{l}\text { Do } \\
\text { Juniperus, roots in ore at } 9 \mathrm{ft}\end{array}$ & July $16 \ldots$ & $\begin{array}{l}7.8 \\
2.0\end{array}$ & 2 & $\begin{array}{r}8.4 \\
20.0\end{array}$ & 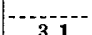 & $1,600.0$ & $\begin{array}{l}540 \\
400\end{array}$ \\
\hline Sarcobatus, roots in ore at $19 \mathrm{ft}$ & July 16 & $\begin{array}{l}2.0 \\
1.3\end{array}$ & & $\begin{array}{l}20.0 \\
11.0\end{array}$ & $\begin{array}{c}0.1 \\
.72\end{array}$ & $\begin{array}{r}140.0 \\
39.0\end{array}$ & \\
\hline Ephedra, roots in ore at $18 \mathrm{ft}$ & May $18 .$. & 9.0 & & & 1.6 & 5. 0 & 19 \\
\hline Chrysothamnus, roots in ore at $8 \mathrm{ft}$ & May $16 \ldots$ & 40.0 & & & & 20.0 & 80 \\
\hline
\end{tabular}

and greasewood is mostly precipitated within the root near the point of intake, as the near-surface roots contain considerably less uranium than do the deeper roots that are spread out along the water-bearing ore zone. Forty near-surface juniper roots collected in the McCoy group contained an average of $7 \mathrm{ppm}$ uranium compared to $1.2 \mathrm{ppm}$ uranium in the branch tips. Transport is apparently active in Ephedra and Chrysothamnus, as the uranium content in roots collected in mines was lower than that in the tops for both plants.

Juniper roots in deep mines could not be traced confidently to a specific tree at the surface-roots were observed at depths of 40 feet beneath the surface in the McCoy group, and at much greater depths in other districts-but the uranium contents of the aerial parts of the trees seemed to coincide well with the known extent of the ore. A juniper has many lateral near-surface roots and one main trunk root that commonly penetrates deeply along fractures to a water-bearing sandstone bed; in the Salt Wash Member the water-bearing sandstone is commonly also ore bearing. Knowing that many trees and shrubs in semiarid country have this growth habit is a valuable aid in prospecting. Woody plants that behave as phreatophytes and penetrate to the water-bearing ore zones are much more useful than the shadscale and other xerophytes whose roots do not penetrate deeper that about 10 feet.

\section{RADIOACTIVE DECAY PRODUCTS}

In addition to uranium, whose effects have just been discussed, ore bodies also contain uranium decay products that vary in quantity depending on the length of time the uranium has remained in its original position. These uranium decay products, radium in particu- 
lar, may be absorbed by plant roots or, to a lesser degree, may be formed directly from absorbed uranium within the plant. The absorption of these newly formed elements, their effect on plant growth, and the effect of radioactivity are, therefore, pertinent to the problem. Accordingly, these effects and their possible use in prospecting were investigated. The interference from artificial fallout emanating from the nearby Nevada Test Site was also considered.

The accumulation of the products of radioactive decay in natural vegetation has not been studied extensively because quantitative methods of analysis have not been available. Drobkov (1937, p. 230) experimented with radium in nutrient solution and found that pea plants at optimum conditions of growth contained $5.02 \times 10^{-12}$ percent radium in the stalks and $1.19 \times 10^{-11}$ in the roots.

The radium, strontium-90, and strontium-89 contents of edible fruits and vegetables grown along the Animas River above and below the uranium mill at Durango, Colo., were studied by Tsivoglou and others (1959) of the U.S. Department of Health, Education, and Welfare. The radium content of the foods of the area ranged from 0.7 to $7.6 \mu \mu \mathrm{c}$ per $\mathrm{kg}$ (micromicrocurie per kilogram) of fresh weight; the strontium-90 content, from 2.5 to $315 \mu \mu \mathrm{c}$ per $\mathrm{kg}$; and the strontium- 89 content, from 0 to $1,740 \mu \mu \mathrm{c}$ per kg. The plants grown upstream contained an average of $2 \mu \mu \mathrm{c}$ per $\mathrm{kg}$ radium compared with an average of 3.6 below the mill. According to the U.S. Atomic Energy Commission (1957), the tolerance limits for radium in foods is $4.0 \mu \mu \mathrm{c} \mathrm{per} \mathrm{kg}$ fresh weight; for strontium-90, the tolerance limit is $80 \mu \mu \mathrm{c}$ per $\mathrm{kg}$.

Anderson and Kurtz $(1955,1956)$ developed a means of employing the alpha radioactivity of plant ash in prospecting. They reported (1955, p. 228) counts above a background of $6 \mathrm{cph}$ (counts per hour) in the following species collected over a small but very radioactive pitchblende ore body in Arizona:

Alpha radioactivity of ash from indicated plants

\begin{tabular}{l|r}
\hline Species & Counts per hour \\
\hline $\begin{array}{l}\text { Quercus emoryi (emory oak) } \\
\text { Q. oblongifolia (Mexican blue oak) }\end{array}$ & $0-135$ \\
Prosopis juliflora var. velutina (common mesquite) & $1-91$ \\
Mimosa dysocarpa (velvet pod mimosa): & $40-82$ \\
$\quad$ Leaves. & $8-64$ \\
Twigs & $26-886$ \\
Prosopis juliflora (common mesquite) & $28-500$ \\
Juniperus deppeana ${ }^{1}-\ldots$ & $10-32$ \\
\hline
\end{tabular}

${ }^{1}$ Anderson and Kurtz (1956, p. 67) compared these two species collected together at stations over a vein deposit. 
Alpha counts made by Anderson and Kurtz (1956, p. 67) on Colorado Plateau plant samples show a regular increase from 118 to $209 \mathrm{cph}$ for sagebrush samples that contain 12-29 ppm uranium. Minor variations in the count rate for plants that contain less than $10 \mathrm{ppm}$ uranium in the ash were masked by the natural radioactivity of potassium in the plant. Anderson and Kurtz concluded that their method of prospecting is not feasible near deposits of low radioactivity nor on plant species that do not accumulate large amounts of radioactive elements.

Near the close of the Yellow Cat project, some of the plants were observed to be sufficiently radioactive to affect a scintillation counter. To determine whether the radioactivity was caused by absorbed radium and was therefore useful in prospecting, four of the species were collected and brought to the radiation laboratory for study. Pioneer research on methods of analyses by J. N. Rosholt and C. G. Angelo produced the data shown in table 22 .

TABLE 22.-Radioactivity measured in four species of plants in the Yellow Cat area

\begin{tabular}{|c|c|c|c|c|c|}
\hline \multirow{2}{*}{ Laboratory No. } & \multirow{2}{*}{ Species } & \multirow{2}{*}{$\begin{array}{l}\text { Radio- } \\
\text { activity } \\
\text { (mr per } \mathrm{hr} \\
\text { over back- } \\
\text { ground) }\end{array}$} & \multicolumn{2}{|c|}{$\underset{\text { (ppm) }}{\text { Beta-gamma }} \in \mathrm{U}$} & \multirow{2}{*}{$\frac{\begin{array}{c}\text { Alpho eU } \\
(\mathrm{ppm})\end{array}}{\text { May } 1955}$} \\
\hline & & & May 1955 & $\underset{1956}{\text { February }}$ & \\
\hline $\begin{array}{r}\mathrm{D}-229578 \ldots \\
579 \\
580 \\
581\end{array}$ & $\begin{array}{l}\text { Astragalus pattersoni } \\
\text { A. preussi } \\
\text { Ephedra viridis. } \\
\text { Atriplex confertifolia }\end{array}$ & $\begin{array}{l}0.003 \\
.0005 \\
.0035 \\
.0035\end{array}$ & $\begin{array}{r}20 \\
150 \\
110 \\
490\end{array}$ & $\begin{array}{l}20 \\
20 \\
30 \\
70\end{array}$ & \\
\hline
\end{tabular}

The percentage of radiation that could be attributed to alpha rays produced by radium and thorium was surprisingly low. The decrease, with time, in beta-gamma radiation in the last three species suggests that a large part of the radiation is due to fallout. The beta-gamma remaining is probably due to potassium. According to Kamen (1946, p. 130), the radioactive potassium-40 isotope forms about 0.012 percent of normal potassium. In plants, however, the assimilation of the isotopes seems to vary. The $\mathrm{K}^{39} / \mathrm{K}^{41}$ ratio in eight plant samples was shown by Kamen to range from 13.7 to 13.23 . From potassium analyses available in Geological Survey files and calculated on a basis of 0.012 percent $\mathrm{K}^{40}$, the Astragalus species should contain about $36 \mathrm{ppm} \mathrm{K}^{40}$ and shadscale should contain about $48 \mathrm{ppm} \mathrm{K}^{40}$ absorbed as a fixed percentage of the normal potassium requirement. The decay product of uranium, $\mathrm{Ra}^{226}$, in a sample of Astragalus was measured by A. B. Tanner by the radon method in an ionization chamber. Existing radon was removed from the sample first, and 
then new radon from the disintegration of $\mathrm{Ra}^{226}$ was allowed to accumulate over a 2-week period. Computations showed that the dry plant material contained $1.0 \times 10^{-10}$ percent $\mathrm{Ra}^{226}$ and that the fresh plant material contained $1.4 \times 10^{-12}$ percent $\mathrm{Ra}^{226}$. This amount is only about 20 times the average quantity found by Drobkov (1937) in the aerial parts of plants grown at optimum conditions in nutrient solution. Alpha-radiation absorbed by plants from uraniferous ores is a minor part, then, of the total radiation in plant life in the Yellow Cat area, and it is masked by both $\mathrm{K}^{40}$ radiation and fallout.

\section{VANADIOM}

TOLERANCE AND GROWTH EFFECTS

The effects of vanadium on the growth of plants were first investigated before the presence of the element in higher plants had actually been detected. These early experiments were concerned mainly with the possible toxic properties of vanadium, as the element occurs as a common impurity in phosphate fertilizers. In 1886, Witz and Osmond showed experimentally that hypovanadic chloride was detrimental to the growth of wheat. Suzuki (1903) found that $10 \mathrm{ppm}$ vanadium sulfate had no effect on the growth of wheat but than 100 ppm was toxic. Ducloux and Cobanera (1911-12) found that a dilute solution of vanadium was mildly stimulating to the growth of pea leaves but that it was depressing to the growth of their roots. Free and Trelease (1917) demonstrated that $20 \mathrm{ppm}$ vanadium was detrimental to young wheat but that at lower concentrations it was beneficial. Krioukov (1931) found that the addition of $22 \mathrm{ppm}$ sodium vanadate diminished oat crops by 80 percent and that the addition of $66 \mathrm{ppm}$ stopped all growth; the initial content in the soil in which the plants were grown was not given. In Japan, Shibuya and Saeki (1934) determined that vanadates had no direct effect on plants, but they stimulated plant metabolism through the activity of the nitrogen-fixing Azotobacter. Scharrer and Schropp (1935) grew wheat, barley, rye, oats, maize, and peas in sand and nutrient solution. They found that 10 to $10^{-2} \mathrm{mg}$ vanadium added to $700 \mathrm{mg}$ of sand slightly stimulated the maize but that greater concentrations were harmful. Peas were the most sensitive of the plants tested; no stimulation was noted for the other plants.

Burk and Horner (1935) proved that molybdenum is a specific catalyst for nitrogen fixation and that only vanadium, out of 22 elements tested, can replace it. Maximum effects were produced at $10^{-11}-10^{-9} \mathrm{~mol}$. concentrations. In Germany, at about the same time, Bortels $(1936,1937)$ tested 40 elements and came to the same conclusion. Bortels' work in Germany was followed by that of Gericke and Rennenkampff (1940a,b), who found that low concentrations of 
vanadium, added as Thomas phosphate, are stimulating to watercultured barley whereas high concentrations are toxic. They found that calcium exerted a protective effect, as $1,250 \mathrm{ppm}$ ammonium vanadate had no adverse effect on the barley in a high-calcium soil. Gericke (1941) reported also that vanadium is more favorable to plants when it is applied as an anion than when it is applied as a cation. Bertrand (1942a) found 3-4 ppm vanadium in the nodules and roots of the legume and lesser amounts in the aerial parts of the plant. Bertrand (1950, p. 431) wrote an excellent review of the early work on vanadium and showed that many of the toxicity symptoms obtained in early experiments were due to the vanadium content of the nutrients and soils used in the experiments. By purifying the reagents he showed that moderately high concentrations are not toxic but that eventually a maximum is reached beyond which the vanadium is always toxic. He concluded that vanadium is necessary to plant life and is not replaceable by any other elements. Finally, Warington (1951) fed nutrient solutions containing combinations of manganese, molybdenum, and vanadium to soybeans and flax and showed that $1 \mathrm{ppm}$ vanadium counteracted some of the symptoms of manganese toxicity and that 10 and $20 \mathrm{ppm}$ vanadium were harmful to growth regardless of the manganese supply. Toxic concentrations first induced a deepening of the green color of the shoot, but this was followed by apical iron-deficiency chlorosis. Iron offset the toxicity of vanadium in nutrient solution when supplied simultaneously with the vanadium (Warington, 1956).

Physiological symptoms of vanadium toxicity in the Yellow Cat area could not be distinguished from those caused by uranium, molybdenum, or selenium as previously described. Therefore, plot experiments were set up outside of the area to control the concentrations of these elements in the soil. Addition of carnotite to the soil stimulated rather than retarded plant growth. Although the soil contained from 400 to $1,000 \mathrm{ppm}$ vanadium, less than $10 \mathrm{ppm}$ of this amount was water soluble. On the other hand, $841 \mathrm{ppm}$ of water-soluble vanadium in the form of sodium vanadate prevented the growth of all planted species during the first year of the experiment. An unidentified species of the mushroom, Amanita, appeared as a volunteer in the control plot and in two vanadium plots where they were much larger. A sample collected from the control plot contained less than $15 \mathrm{ppm}$ vanadium; one from the vanadium-lime plot, $200 \mathrm{ppm}$ vanadium in the ash.

During the second year of the experiment, the following plants were harvested from soils containing the maximum contents of water- 
Experiments in adsorption of vanadium

[Analyst: H. M. Nakagawa]

\begin{tabular}{c|r|r}
\hline Species harvested above ground & $\begin{array}{c}\text { Vanadium con- } \\
\text { tent in plant ash } \\
\text { (ppm) }\end{array}$ & $\begin{array}{c}\text { Water-soluble } \\
\text { vanadium in soil } \\
\text { (ppm) }\end{array}$ \\
\hline Grindelia aphanactis Rydb. (Composite) & 150 & 140 \\
Cleome serrulata Pursh (Caper) & 80 & 280 \\
Descurainia obtusa (Greene) Schulz (Crucifer) & 80 & 560 \\
Verbesina encelioides var. exauriculata Robins \& \\
Greenm. (Composite)
\end{tabular}

soluble vanadium shown. Toxicity symptoms were extreme dwarfing and chlorosis.

As these species were the only plants able to grow in the plots, they probably represent those most tolerant of vanadium. The species able to grow in the most vanadiferous soil contained the least vanadium. A Grindelia sample collected the following year from the same plot after the amount of water-soluble vanadium had presumably lessened still further contained $30 \mathrm{ppm}$ vanadium in the leaves, $20 \mathrm{ppm}$ in the fruits, $50 \mathrm{ppm}$ in the stems, and $500 \mathrm{ppm}$ in the roots. Verbesina growing in a carnotite plot had only $10 \mathrm{ppm}$ vanadium in the tops but $1,500 \mathrm{ppm}$ in the roots. This species is obviously tolerant of mineralized ground because the uranium and vanadium are precipitated in the roots, and the aerial parts of the plant are relatively unaffected.

Further experiments using nutrient solutions containing vanadium were conducted by Mary Durrell. Sorghum plants placed in solution containing $100 \mathrm{ppm}$ vanadium died at the end of 2 weeks, those in weaker solutions were variously stunted, and those in solutions containing only $1 \mathrm{ppm}$ vanadium did not differ from the control specimens. Astragalus preussi, on the other hand, was unaffected by solutions containing $100 \mathrm{ppm}$ vanadium.

Thus, vanadium is more insoluble in the soils of a carnotite environment than is sodium vanadate. The tolerance of the different species to vanadium may not be a significant factor in the development of an indicator flora.

\section{ACCUMULATION}

The accumulation of vanadium in plants has been studied for a much longer time than has the accumulation of uranium. The first scientific study of vanadium in higher plants was made about 1900 by Demarcay (1900), who reported vanadium in two conifers, in three deciduous trees, and in grapes. In Argentina, Ramirez (1914) found more vanadium in plants growing on vanadiferous soils than on normal soils, but he did not report specific contents. Robinson, 
Steinkoenig, and Miller (1917) developed a colorimetric method for determining the presence of vanadium and reported traces of vanadium in 6 out of 50 plants sampled. Ter Meulen (1931) reported a vanadium content of $3.3 \mathrm{ppm}$ in the dry weight of a mushroom and 0.8 $\mathrm{ppm}$ in garlic. Byers (1934, p. 122) reported a value of $2.5 \mathrm{ppm}$ vanadium in the dry weight of wheat grown in soil containing 130 ppm vanadium. Bertrand $(1941 ; 1942 \mathrm{a}, \mathrm{b})$ agreed with Ter Meulen's findings. He reported an average vanadium content of $1 \mathrm{ppm}$ in the dry weight of plants and $7.1 \mathrm{ppm}$ in the ash. Analyses ranged from 0.152 to $4.2 \mathrm{ppm}$ vanadium in the dry weight of aerial parts, from 0.1 to $12.14 \mathrm{ppm}$ in the dry weight of roots, and from less than 0.01 to $1.2 \mathrm{ppm}$ in the dry weight of seeds. He (1950, p. 426) found also that plants growing in soils richer in vanadium absorbed more vanadium. The vanadium content of the nitrogen-fixing nodules of legumes was about the same as that in the roots.

Mitchell (1954) collected certain species of plants from two areas during four periods in each of 3 different years. All samples contained less than $0.1 \mathrm{ppm}$ vanadium in their dry weight except Calluna (heather), which contained $0.8 \mathrm{ppm}$. W. O. Robinson and Glen Edgington (written communication, 1959) also studied the vanadium content of soils and plants. In the soils analyzed the vanadium content ranged from 8 to $507 \mathrm{ppm}$, and in the plants analyzed the vanadium content ranged from 0.1 to $0.9 \mathrm{ppm}$ dry weight. The greatest concentrations were in legumes and grasses. Robinson and Edgington suggested that the absorption of vanadium is higher from alkaline soils.

The absorption of vanadium by some plants growing naturally in alkaline soils of the Yellow Cat area is very high. The results of analyses are shown in table 16 . Those plants that concentrate vanadium from mineralized ground are listed separately in table 23, and the marked accumulation of vanadium by certain species is apparent. All the species listed are highly tolerant of mineralized ground, and many of them act as indicators. The concentrations of vanadium in Cowania stansburiana may explain the plant's reputation in the early days of mining as "vanadium bush." Astragalus preussi and $A$. confertiflorus concentrate large quantities of vanadium, and their distribution around mineral deposits may be controlled by vanadium. Astragalus pattersoni, however, does not accumulate vanadium. The distribution of the three plant species in the vicinity of mineral deposits is usually different, and it may depend on the relative availability of molybdenum and vanadium.

The ratio of vanadium in plants to vanadium in the soil near carnotite deposits in the Yellow Cat area is actually low compared to the same ratio near other types of deposits in the Western United 
TABLE 23.-Vanadium accumulator plants of the Yellow Cat area and their average vanadium content, in parts per million

[Laboratory numbers and analysts are given in table 16]

\begin{tabular}{|c|c|c|c|c|}
\hline \multirow[t]{2}{*}{ Plant species } & \multicolumn{2}{|c|}{$\begin{array}{l}\text { Average vanadium } \\
\text { content of plants } \\
\text { grown in } \\
\text { mineralized ground }\end{array}$} & \multicolumn{2}{|c|}{$\begin{array}{l}\text { Average vanadium } \\
\text { content of plants } \\
\text { grown in un- } \\
\text { mineralized ground }\end{array}$} \\
\hline & In ash & $\begin{array}{l}\text { In dry } \\
\text { weight }\end{array}$ & In ash & $\begin{array}{l}\text { In dry } \\
\text { weight }\end{array}$ \\
\hline Allium macropetalum & 700 & 133 & & \\
\hline Aster venustus & 85 & 21 & 15 & 3.7 \\
\hline Astragalus confertiflorus. & 900 & 144 & 30 & \\
\hline preussi & 560 & 67 & 18 & 2. 16 \\
\hline thompsonae & 95 & 31 & 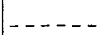 & $-\ldots$ \\
\hline Castilleja angustifolia & 100 & 22 & $-\ldots-1$ & 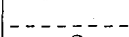 \\
\hline Chrysothamnus viscidiforus.-- & 139 & 37 & 21 & 3 \\
\hline Cowania stansburiana...... & 185 & 7. 4 & 26 & $<$ \\
\hline Eriogonum inflatum & 125 & 15 & 25 & 3 \\
\hline Grindelia fastigiata & 55 & 4. 4 & 20 & 1. 6 \\
\hline Gutierrezia divaricata & 155 & 9.3 & 40 & 2. 4 \\
\hline Lepidium montanum & 55 & 11 & & .... \\
\hline Oryzopsis hymenoides & 165 & 10 & 40 & 2. 4 \\
\hline Yucca harrimaniae & 70 & 3. 5 & & $\ldots \ldots$ \\
\hline
\end{tabular}

States. The absorption of uranium and vanadium by plants in the Yellow Cat area as compared to that by plants in areas around other types of mineral deposits is shown by a graph in figure 7. In uranium deposits that contain a large amount of calcium carbonate, proportionally more uranium than vanadium is translocated to the upper parts of the plant from a given amount of each in the soil. Apparently calcium vanadate is formed in the root. In experimental plot studies, the contents of vanadium in the above-ground parts of the plants were depressed by lime, gypsum, and phosphate but were generally increased in plots containing selenium. Uranium absorption was most favored by sulfates and selenates.

By far the greatest concentration of ranadium in a plant occurs in the roots. A root sampled near the ground surface, though, contains less vanadium than the same root sampled at depth in the orebearing sandstone. Thirty-five near-surface juniper roots collected in the McCoy group averaged $110 \mathrm{ppm}$ vanadium; the branch tips of the same trees averaged $55 \mathrm{ppm}$. A peeled juniper root collected from within the ore bed contained $2,200 \mathrm{ppm}$ vanadium, whereas at the surface another part of the same root contained only $78 \mathrm{ppm}$. The analyses shown in table 16 indicate that the vanadium content of plants increases throughout the growing season.

The uranium content of the plants correlated more precisely with the uranium content of the underlying sandstone than the vanadium content of plants correlated with vanadium content of the sand- 


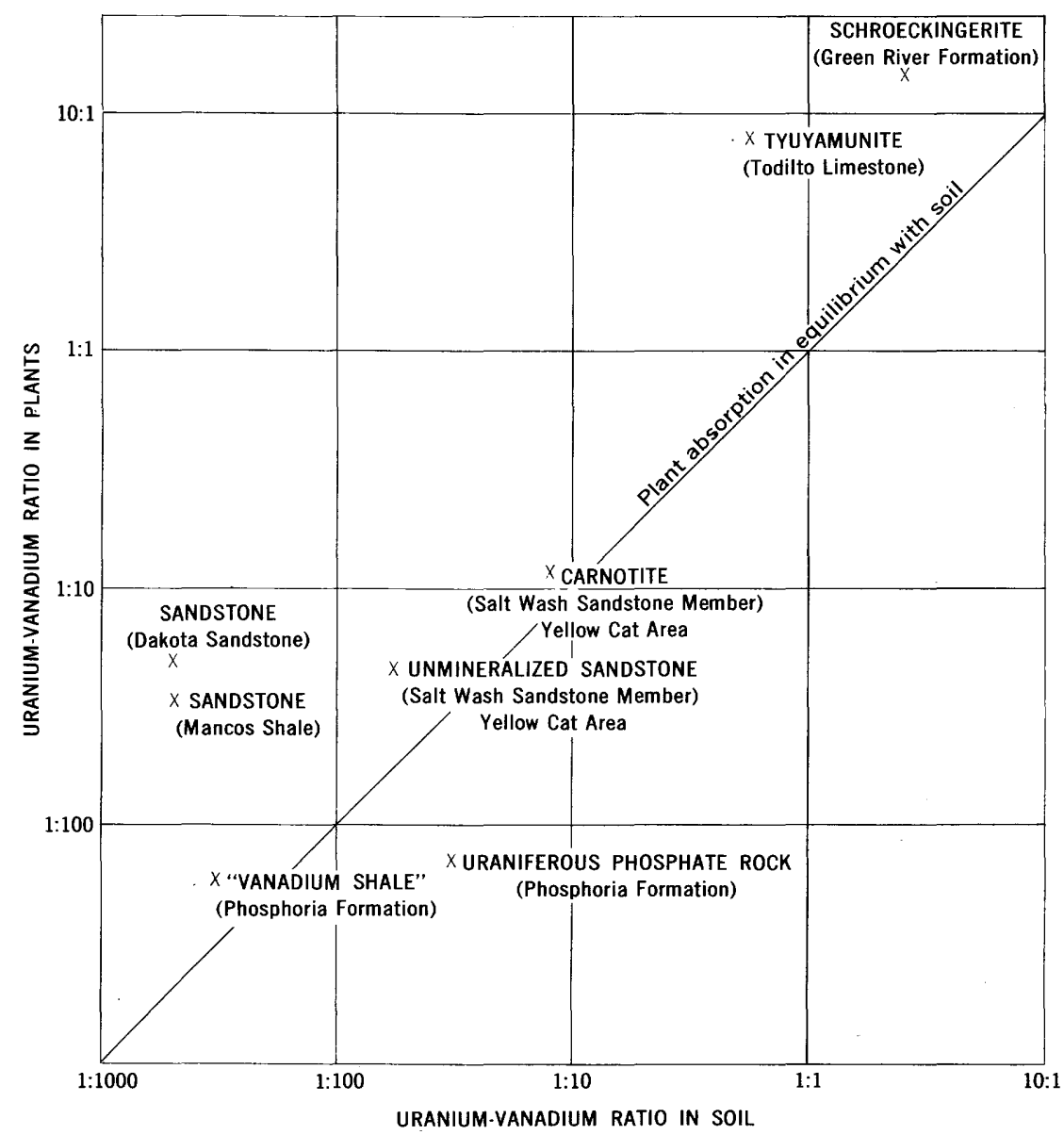

FIGURE 7.-Graph showing the ratio of uranium uptake to vanadium uptake by plants growing in different chemical environments.

stone; therefore, vanadium is not considered a pathfinder element in prospecting for uranium deposits.

\section{MOLYBDEN UM}

TOLERANCE AND GROWTH EFFECTS

The plants of the Yellow Cat area are highly tolerant of molybdenum and take up large quantities. The $\mathrm{pH}$ of the soil has a direct effect on the availability of molybdenum to vegetation; molybdenum differs from most other metals in this respect because it is more available to plants in an alkaline environment. At a $\mathrm{pH}$ of less than 7.5, insoluble aluminum and iron molybdates are formed (Evans, Purvis, and Bear, 1951), and more molybdenum remains adsorbed on the soil colloids; at a $\mathrm{pH}$ of 3 , very little molybdenum is adsorbed by plants; at a $\mathrm{pH}$ of 5.5 , a greater absorption of molybdenum is indicated by light-green chlorosis of the leaves. At a $\mathrm{pH}$ of 7.5 , the maximum 
amounts of molybdenum are absorbed. On the other hand, molybdenum may be mostly leached out of naturally alkaline soils so that the plant content may be low. Stout and others (1951) demonstrated that the absorption of molybdenum by plants can be decreased by adding sulfates. According to Cripps (1955), uptake of molybdenum is decreased also by high contents of iron oxide and manganese.

Plants growing in alkaline soils may thus develop toxicity symptoms and take up enough molybdenum to be decidedly toxic to the animals that consume them. Warington (1937) described symptoms produced in members of the Solanaceae as golden- to reddish-yellow shoots caused by yellow globules of a tannin-molybdenum compound formed within the tissues. Blue granular accumulations that apparently consisted of an anthocyanin-molybdenum compound were also found in tissues containing anthocyanin pigment. Agarwala and Hewitt (1954) found blue granules in the leaves of cauliflower that were fed more than $19 \mathrm{ppm}$ molybdenum in nutrient solution. Parts of leaves having the blue color caused by excess molybdenum did not contain more molybdenum than similar green parts of the same leaves.

A disease called teart, which is fatal to cattle pastured on calcareous clay soils derived from the lower part of the Lias Series of England, was shown by Ferguson, Lewis, and Watson $(1938,1940,1943)$ and Lewis (1943) to be caused by excesses of available molybdenum. Teart soils that contained 20-100 ppm molybdenum supported forage that contained $20-100 \mathrm{ppm}$ molybdenum in the dry weight. A similar chronic disturbance in cattle was discovered by Britton and Goss (1946) in California. Alkaline soils in San Joaquin Valley (Barshad, 1948) contained as much as $10 \mathrm{ppm}$ molybdenum in the surface soils and supported vegetation that contained more than $20 \mathrm{ppm}$ molybdenum in dry weight, a content which caused illness in cattle. The molybdenum occurred in the soil as a soluble molybdate anion (Barshad, 1951). The molybdenum content of the plant was about proportional to the water-soluble-molybdenum content of the soil at $\mathrm{pH}$ values between 4.7 and 7.5 ; above a $\mathrm{pH}$ of 7.5 the watersoluble-molybdenum content of the plant was less than the content of the soil.

The surface soils in the Yellow Cat area are very alkaline and contain from 7 to $13 \mathrm{ppm}$ molybdenum. The barren sandstone beds contain less than $7 \mathrm{ppm}$ molybdenum, but the ores average $103 \mathrm{ppm}$. Thus, little molybdenum occurs in the barren areas of the district, but the amount of molybdenum in the ores is enough to retard or to poison plants rooted in mineralized ground.

As discussed earlier, the symptoms of molybdenum toxicity cannot be separated from those of uranium or vanadium toxicity, as the ores contain large amounts of all three elements; but the reddish coloration 
of the stems and pods of Astragalus rooted in mine dumps may be attributable to molybdenum. A similar coloration was observed by Warington (1937). The molybdenum contents of Grindelia, Aster venustus, and Astragalus pattersoni in the Yellow Cat area were greater than those of forage that produced toxic effects in cattle in California (Barshad, 1948). The additive dose of toxic molybdenum and toxic selenium in the same plants of Yellow Cat is extremely lethal to sheep.

ACCUMULATION

The presence of molybdenum in plants was first noted by Demarçay (1900), who determined this element as well as vanadium and chromium in a spectrographic analysis of plant ash. Molybdenum was later detected spectrographically by Dingwall, McKibbon, and Beans (1934) in a large variety of plants growing downstream from a Canadian molybdenum deposit. The first quantitative report of unusual concentrations of molybdenum in plants was made by Beath, Eppson, and Gilbert (1935, p. 36-37) in connection with toxicity problems related to selenium concentrations in the Cretaceous shales of Wyoming. They found $317 \mathrm{ppm}$ molybdenum in the dry weight of the tops of Oonopsis condensata and $124 \mathrm{ppm}$ in the roots. Xylorrhiza parryi was also reported to be an accumulator. Hay that contained $89 \mathrm{ppm}$ molybdenum and was fed to livestock produced symptoms of poisoning similar to those of selenium poisoning.

At about the same time that heart disease was being studied in England, Bertrand $(1939,1940 \mathrm{a}, \mathrm{b})$ investigated the distribution of molybdenum in plants in France. He found that crucifers and legumes had the greatest concentrations of molybdenum; cereals averaged $0.2-0.6 \mathrm{ppm}$ molybdenum in their dry weight, and seeds of legumes averaged 3-9 $\mathrm{ppm}$.

Robinson and Edgington (1947) reported the following analyses for toxic vegetables raised in a seleniferous area of Colombia, South America: $11 \mathrm{ppm} \mathrm{MoO}_{3}$ in the dry weight of wheat, $12.6 \mathrm{ppm}$ in corn, and the extremely high content of $137.0 \mathrm{ppm}$ in peas. They suggested that the toxicity of the vegetables might be caused by the molybdenum as well as by the selenium. Westerfeld and Richert (1953) reported $0.25-4.69 \mathrm{ppm}$ molybdenum in legume seeds, $0.12-1.14 \mathrm{ppm}$ in cereal grains, and 0.14-0.54 ppm in onions. Marmo (1955) found as much as $35 \mathrm{ppm}$ molybdenum in the dry weight of leaves of Ledum palustre rooted in copper-bearing granites in Finland that contained $200 \mathrm{ppm}$ molybdenum, and 5-10 ppm when the plant was rooted in rock containing 5-10 ppm molybdenum. The branches contained no more molybdenum than the leaves.

Malyuga (1958) reported that Astragalus aurens var. lagurus, Gentiana, alfalfa, Scabiosa, and Anthriscus silvestris were accumulators 
of molybdenum. Plants of these genera that grew in mineralìzed ground contained from 100 to $500 \mathrm{ppm}$ in the ash.

Trace elements in native vegetation of Finland were studied intensively by Lounamaa (1956), who reported the following average molybdenum contents in the various plant groups:

Trace elements in native vegetation of Finland

\begin{tabular}{|c|c|c|c|}
\hline Plant group & $\begin{array}{l}\text { Average molybdenum } \\
\text { in the ash } \\
\text { (ppm) }\end{array}$ & $\begin{array}{l}\text { Maximum molyb- } \\
\text { denum in the ash of } \\
\text { plants collected from } \\
\text { mineralized ground } \\
(\mathrm{ppm})\end{array}$ & Accumulator species \\
\hline Lichens _. . . . & 19 & 100 & \\
\hline Mosses_........ & 30 & 200 & Tortella. \\
\hline Ferns_............ & 14 & 300 & Lastrea. \\
\hline Conifers & $<10$ & 60 & Picea abies. \\
\hline $\begin{array}{l}\text { Deciduous trees } \\
\text { and shrubs. }\end{array}$ & $\begin{array}{l}15 \text { (leaves) } \\
18 \text { (twigs) }\end{array}$ & 300 & Betula verrucosa. \\
\hline Dwarf shrubs $\ldots$ & 10-30 (leaves) & 300 & Calluna vulgaris. \\
\hline Herbs & 20 (leaves) & 600 & $\begin{array}{l}\text { Vicia cracca. } \\
\text { Deschampsia } \\
\text { caespitosa. }\end{array}$ \\
\hline
\end{tabular}

A definite decrease in molybdenum content from June to September was noted in most of the collections. This decrease does not agree with the findings of Mitchell (1954) and Marmo (1955), who reported no significant difference, or with those of Barshad (1948), who reported a twofold to threefold increase in molybdenum content of pasture grasses. Ter Meulen and Ravenswaay (1935) found that the molybdenum content decreased in some species and increased in others; this difference may explain the discrepancy described. In the Yellow Cat area, samples of juniper or sagebrush collected in May and September showed no significant difference in molybdenum content.

Lounamaa (1956) found that the stems consistently contained more molybdenum than the leaves. Probably the greatest accumulations of molybdenum occur in the seeds and root nodules of legumes.

Many samples of roots and tops were collected from the Yellow Cat area for comparison of molybdenum content. The ratio between molybdenum contents of roots and tops varied widely, as shown in table 18. Specifically, Oryzopsis, Ephedra, Juniperus, Y ucca, and Atriplex contained more molybdenum in the tops than in the roots; Quercus, Fraxinus, Chrysothamnus, and Lepidium had no consistent difference; and Grindelia, Eriogonum, and the Astragalus species contained more molybdenum in the roots than in the tops. No fruiting parts were analyzed separately except for juniper berries, which contained very little molybdenum. 
The accumulation of molybdenum by plants on the Colorado Plateau is greater near uranium deposits. This phenomenon was first noticed by Beath (1943) during his studies of selenium indicator plants around the ore deposits in the Thompson district. Many of the molybdenum accumulator species shown in table 25 are also accumulators of selenium and belong in the Leguminosae, Chenopodiaceae, Cruciferae, and Compositae families. The amounts that are accumulated vary considerably depending on factors that affect the availability, so that the molybdenum content in the plant does not reflect accurately the molybdenum content in the rocks or soil. The absorption of molybdenum from the soil was greatest in the schroeckingerite deposit at the east end of the Yellow Cat area. Here the soil contained 1-3 ppm molybdenum, but the ash of the plants contained the following amounts.

Molybdenum in ash of plants over schroeckingerite deposit, east end of Yellow Cat area

\begin{tabular}{|c|c|c|}
\hline & Tops (ppm) & Roots (ppm) \\
\hline $\begin{array}{l}\text { Ephedra viridis } \\
\text { Tamarix gallica } \\
\text { Atriplex confertifolia } \\
\text { Grindelia fastigiata } \\
\text { Astragalus pattersoni } 1 \text {. } \\
\quad \text { Do. } \\
\text { Do }\end{array}$ & $\begin{array}{l}300 \\
200 \\
165 \\
960 \\
500 \\
178 \\
100 \\
300\end{array}$ & 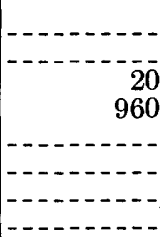 \\
\hline
\end{tabular}

1 The samples of Astragalus pattersoni and A. preussi that were collected at the same time from the same soil contained 500 and $300 \mathrm{ppm}$ molybdenum, respectively.

The molybdenum content of vegetation has been considered by several workers as a guide in prospecting. Warren, Delavault, and Routley (1953) proposed that molybdenum might be used as a pathfinder element in prospecting for copper and tungsten. Trifolium collected by Baranov (1957) over a molybdenum deposit was used in outlining the mineralized ground; the plant contained $54-120 \mathrm{ppm}$ molybdenum in its ash or 32-137 ppm molybdenum in its dry weight. Samples of Cneoridium dumosum (berryvine) that contained $200 \mathrm{ppm}$ in the ash, in contrast to a background of $10 \mathrm{ppm}$, were used in outlining an anomaly over a molybdenum-bearing dike in California (Carlisle and Cleveland, 1958, p. 22-26). The uptake was not affected by differences of from 5.9 to $6.9 \mathrm{in} \mathrm{pH}$ of the soil or by the clay content. At another locality, molybdenum mineralization along a contact metamorphic zone was reflected in the molybdenum content of leaves and twigs of live oak. The Quercus wislizeni samples contained as much as $140 \mathrm{ppm}$ molybdenum compared with a background of $10 \mathrm{ppm}$. The $\mathrm{pH}$ of the soil could not be shown to have a consistent effect on the availability of the molybdenum. Malyuga (1958) used 
molybdenum contents as a guide in prospecting for copper in Armenia where the molybdenum content of the plants ranged from 30 to 1,000 ppm molybdenum in the ash. Molybdenum contents were greater in herbs than in trees, and the element was concentrated in the leaves. The use of molybdenum as a tracer in uranium prospecting was not considered by R. E. Gilbert (written communication, 1954) to be practical in Marysvale, Utah; although the molybdenum values in sagebrush-20-60 ppm in the ash of stems and $20-200 \mathrm{ppm}$ in the ash of tips-varied with uranium content, the variations were not consistent in either plants or soils. The same conclusion was reached in the present studies of the Yellow Cat area. Accumulations of molybdenum in plants of the Yellow Cat area, as reported by Beath (1943) and by the U.S. Geological Survey laboratories, are given in table 24. Large amounts of molybdenum were found in the vegetation

TABLE 24.-Molybdenum accumulator plants of the Yellow Cat area (probably toxic to livestock)

[Laboratory numbers and analysts shown in table 16]

\begin{tabular}{|c|c|c|c|c|c|c|c|}
\hline \multirow{3}{*}{ Species } & \multirow{3}{*}{$\begin{array}{c}\text { Ash, in } \\
\text { percent }\end{array}$} & \multirow{2}{*}{\multicolumn{2}{|c|}{$\begin{array}{l}\text { Early collections by } \\
\text { Beath }(1943)(\mathrm{ppm})\end{array}$}} & \multicolumn{4}{|c|}{ U.S. Geological Survey collections } \\
\hline & & & & \multicolumn{2}{|c|}{$\begin{array}{l}\text { Average molybde- } \\
\text { num content, in } \\
\text { parts per million, } \\
\text { in plants growing } \\
\text { in unmineralized } \\
\text { ground }\end{array}$} & \multicolumn{2}{|c|}{$\begin{array}{l}\text { Average molyb- } \\
\text { denum content, in } \\
\text { parts per million, } \\
\text { in plants growing } \\
\text { in mine rali zed } \\
\text { ground }\end{array}$} \\
\hline & & $\begin{array}{c}\text { Dry } \\
\text { weight }\end{array}$ & Ash & $\underset{\text { weight }}{\text { Dry }}$ & Ash & $\begin{array}{c}\text { Dry } \\
\text { weight }\end{array}$ & Ash \\
\hline $\begin{array}{l}\text { Aster venustus } \\
\text { Astragalus confertifiorus. } \\
\quad \text { pattersoni } \\
\text { Atriplex canescens } \\
\quad \text { confertifolia } \\
\text { Castilleja integrifolia } \\
\text { Chrysothamnus viscidiflorus } \\
\text { Grindelia fastigiata } \\
\text { Gutierrezia sp } \\
\text { Lepidium montanum } \\
\text { Tamarix gallica }\end{array}$ & $\begin{array}{r}15 \\
12 \\
14 \\
13 \\
26 \\
22 \\
15 \\
7 \\
6 \\
20 \\
: 12\end{array}$ & 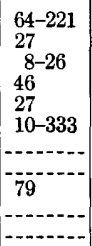 & \begin{tabular}{l}
$420-1,470$ \\
103 \\
$57-190$ \\
354 \\
103 \\
$45-1,500$ \\
\hdashline 1,300 \\
\hdashline \\
\hdashline
\end{tabular} & $\begin{array}{r}3-45 \\
4 \\
8.4 \\
1.3-5.8 \\
<2-10.4 \\
6.6 \\
1-1.5 \\
2.1 \\
1.5-2.4 \\
-\end{array}$ & \begin{tabular}{l}
$20-300$ \\
33 \\
60 \\
$10-40$ \\
$<7-40$ \\
30 \\
$<7-10$ \\
30 \\
$25-40$ \\
\hdashline-
\end{tabular} & \begin{tabular}{r}
105 \\
19.2 \\
$14-70$ \\
\hdashline $1.8-78$ \\
3.3 \\
$3-18.7$ \\
$3.5-6.7$ \\
$1.8-12$ \\
$16-24$ \\
$1.2-24$
\end{tabular} & \begin{tabular}{l}
700 \\
160 \\
$100-500$ \\
\hdashline $7-300$ \\
15 \\
$20-125$ \\
$500-960$ \\
$30-200$ \\
$80-120$ \\
$10-200$
\end{tabular} \\
\hline
\end{tabular}

near ore deposits, but the molybdenum content varies greatly within the same species, and thus analyses for molybdenum are more difficult to interpret than are the uranium analyses. The variability presumably is due to the extreme solubility of molybdenum under alkaline desert conditions.

\section{SELENIOM}

TOLERANCE AND GROWTH EFFECTS

Selenium, because of its ubiquitous occurrence in Western United States, its accumulation by certain indicator plant groups, and its toxicity to animals and humans, is probably the most significant pathfinder element on the Colorado Plateau. 
Plant species vary enormously in their tolerance for, and accumulation of, available selenium in the soil. The selenium content of plants correlates poorly with the total selenium content of the soil because of the variability both in the availability of selenium and in the absorption habits of various plant groups. Trelease and Beath (1949, p. 146) showed that

$* * *$ the water-soluble fraction of the selenium varies widely in different soils ranging from only about 1 percent to as much as 90 percent.

Even the water-soluble forms - selenite, selenate, organic selenium, and so forth are not equally available to the plant-so that the only reliable method of determining the selenium-supplying power of a soil is to determine the selenium content of the various species of plants growing on the soil.

Williams and Byers (1936) found that the inorganic selenium content of the soils occurred mainly in the form of basic ferric selenite, whereas the water-soluble fraction was largely calcium selenate. Other laboratory studies have shown that sodium or potassium selenite added to the soil is made insoluble by adsorption in iron and aluminum hydroxides (Olson, 1939). Selenates, on the other hand, are not so adsorbed (Olson and Jensen, 1940). Field studies of South Dakota soils suggest that most of the soluble selenium is in the form of selenate but that smaller amounts of selenite are also present (Olson, Whitehead, and Moxon, 1942).

Possibly small amounts of selenium are necessary to all plants; at any rate, it can be demonstrated that selenium is necessary to the so-called group of selenium indicator or accumulator plants that absorb selenium in very large quantities. The difficulty in proving the essentiality of selenium in plants lay in acquiring selenium-free seeds with which to experiment. Levine (1925) was the first investigator to show that certain plants are stimulated by $1-10 \mathrm{ppm}$ of selenium dioxide and are harmed by more than $100 \mathrm{ppm}$. Trelease and Trelease $(1938 \mathrm{a}, \mathrm{b} ; 1939)$ found that $27 \mathrm{ppm}$ selenium as $\mathrm{Na}_{2} \mathrm{SeO}_{3}$ would retard the growth of the selenium accumulator, Astragalus racemosus, and that $81 \mathrm{ppm}$ would stunt the whole plant. The growth of the species was stimulated in solutions containing $0.3-0.9 \mathrm{ppm}$ selenium. Trelease (1942) was able to separate 25 Astragalus species into two groups: those stimulated by a high concentration of $\mathrm{Na}_{2} \mathrm{SeO}_{3}$, and those poisoned by a much lower concentration. Stanford and Olson (1939) found that concentrations of $0.01-0.05 \mathrm{ppm}$ sodium selenite caused root elongation in wheat and that corn was stimulated by amounts less than $0.05 \mathrm{ppm}$.

The selenium-absorbing abilities of some plants were studied experimentally outside the Yellow Cat area. This was done by adding sodium selenite and carnotite to the soil in which several representative plant groups were growing. Some of the results of the study are shown in table 25. Plants showed a wide variation in selenium 
TABLE 25.-Tolerance of plants grown experimentally for 3-4 years in seleniferous soils

[Figures in parentheses are selenium content of ash, in parts per million; n.d., not determined. Analysts: J. H. McCarthy, J. W. Meadows, A. P. Marranzino, and H. E. Crowe]

\begin{tabular}{|c|c|c|c|c|c|c|c|}
\hline Laboratory No. & Species & $\begin{array}{l}\text { Perennial or } \\
\text { annual }\end{array}$ & $\begin{array}{c}\text { Control } \\
(1953-56)\end{array}$ & 11953 & 1954 & 1955 & 1956 \\
\hline $\begin{array}{l}\text { D-218808, GX-55-4791, GX-57-216, } \\
\text { GX-55-4800. }\end{array}$ & $\begin{array}{l}\text { Astragalus patter- } \\
\text { soni. }\end{array}$ & Perennial ... & $\begin{array}{l}\text { Germinated, } \\
\text { turned white } \\
\text { and died out }\end{array}$ & $\begin{array}{l}\text { Healthy seedlings } \\
\text { (n.d.). }\end{array}$ & $\begin{array}{l}\text { Healthy, } 20 \text { in. } \\
\text { matured }(5,000) .\end{array}$ & $\begin{array}{l}\text { Healthy, } 31 \text { in. } \\
\text { matured }(5,550) .\end{array}$ & $\begin{array}{l}\text { Healthy, matured } \\
(12,000) .\end{array}$ \\
\hline $\begin{array}{l}D-218804, G X-55-4844, G X-56-4804 \\
\text { GX-55-4837. }\end{array}$ & Stanleya pinnata.... & -.._do_....... & $\begin{array}{l}\text { Grew to spindly } \\
21 \text { in. second }\end{array}$ & (ndon & $\begin{array}{l}\text { Healthy, } 41 \text { in. } \\
\text { matured (92.0). }\end{array}$ & $\begin{array}{l}\text { Healthy } 39 \text { in. } \\
\text { matured }(1,830) .\end{array}$ & $\begin{array}{l}\text { Healthy, matured } \\
\text { (n.d.). }\end{array}$ \\
\hline D-99554, D-218796, GX-55-4832_... & Cleome serrulata & Annual. .... & No germination... & Healthy. matured & Healthy, 34 in. & Healthy, 32 in. & Not planted. \\
\hline $\begin{array}{l}D-218813, G X-55-4877, G X-57-228, \\
D-218819\end{array}$ & Grindelia aphanactis_ & Perennial_-_- & Healthy (25) & $\begin{array}{l}\text { Not able to grow } \\
\text { in seleniferous } \\
\text { soils unless } \\
\text { carnotite also }\end{array}$ & $\begin{array}{l}\text { matured (309). } \\
\text { Selenium +carno- } \\
\text { tite necessary } \\
(\mathbf{1 5 0 ) .}\end{array}$ & $\begin{array}{l}\text { matured (250). } \\
\text { Selenium + carno- } \\
\text { tite necessary } \\
(700) .\end{array}$ & $\begin{array}{l}\text { Selenium+carno- } \\
\text { tite necessary } \\
(2,600) .\end{array}$ \\
\hline D-218795, GX-55-4822, D-218794 & Verbesina encelioides & Annual...... & Healthy (12.8) & Healthy (n.d.) .... & Healthy (437).....- & Healthy $(50) \ldots . .$. & Healthy (n.d.). \\
\hline GX-55-4869 & Allium sp.ericutata. & -._do_.....- & $\begin{array}{l}\text { Healthy, } 13 \text { in. } \\
\text { (n.d.). }\end{array}$ & Germinated, & $\begin{array}{l}\text { Thin, sparse } \\
\text { (n.d.). }\end{array}$ & $\begin{array}{l}\text { Healthy, } 13 \text { in. } \\
(3,000) .\end{array}$ & Not planted. \\
\hline D-218777, GX-55-4782, D-218783.... & Descurainia obtusa... & ................ & $\begin{array}{l}\text { Healthy, } 21 \text { in. } \\
\text { (15). }\end{array}$ & No germination... & Fair (227) & $\begin{array}{l}\text { Healthy, } 36 \text { in. } \\
\text { (n.d.). }\end{array}$ & Healthy (n.d.). \\
\hline $\begin{array}{l}\text { Total selenium in top } 3 \text { in. of soil } \\
\text { Water-soluble fraction. }\end{array}$ & & $n-$ & $<1-2$ & $\begin{array}{r}125-175 \\
6-10\end{array}$ & $\begin{array}{r}70-100 \\
1-2\end{array}$ & $\begin{array}{l}5-7 \\
1-2\end{array}$ & $\begin{array}{l}\text { n.d. } \\
\text { n.d. }\end{array}$ \\
\hline
\end{tabular}

$1 \mathrm{Na}_{2} \mathrm{SeO}_{3}$, added to top 3 inches in 1953: soil reanalyzed in surface 3 inches for next 2 years. 
uptake. The perennial Astragalus pattersoni, grown for 4 years on a plot in which the selenium in the top 3 inches of soil was gradually lessening, showed an increase in selenium content to a maximum of $12,000 \mathrm{ppm}$, computed in the ash; the perennial Grindelia aphanactis, grown on the same plot and for the same length of time, contained $2,600 \mathrm{ppm}$ in ash. The annuals, in contrast, decreased steadily in selenium content each year as the total selenium content of the soil decreased; for instance Cleome serrulata contained $540 \mathrm{ppm}$ the first year, 309 the second year, and 250 the third year. Olson, Jornlin, and Moxon (1942) demonstrated that perennials which have welldeveloped root systems are dependent on the availability of the selenium in the second and third feet of soil. The water-soluble selenium content of the near-surface soil of all plots was never more than $10 \mathrm{ppm}$ and was probably as low as one-tenth ppm in the control soil. In this plot, no plant absorbed more than $50 \mathrm{ppm}$ selenium. Astragalus pattersoni, Stanleya pinnata, and Cleome serrulata were unable to grow in the control plot, but their growth was greatly stimulated in all seleniferous plots. This group requires selenium for growth and stores sufficient selenium in the seed to enable the plant to germinate and grow to a height of an inch or more. If no additional selenium is available at this stage in the development, the plant dies. Three other species-Grindelia aphanactis, Allium sp., and Descurainia obtusa-did not grow in the most seleniferous soils during the first season but grew well the second and third years, particularly in plots where carnotite was also added. Verbesina encelioides var. exauriculata, a ubiquitous volunteer weed, was not deterred by any treatment.

Symptoms of toxicity were dwarfing and chlorosis; some plants turned completely white. Similar symptoms were described by Trelease and Beath (1949, p. 147) and by Hurd-Karrer (1934, 1937) as results of selenate poisoning. Hurd-Karrer (1935, 1937) found that the addition of sulfur reduced the uptake of selenium by wheat. Trelease and Trelease (1938b) found that an excess of sulfur reduced the selenium content of Astragalus racemosus to 0.3-0.6 percent of the value taken up in the absence of sulfur. Maximum yield occurred at a ratio of sulfur to selenium of $9: 1$. Martin (1936) reported that the sulfur-selenium antagonism was more effective on wheat and buckwheat at low concentrations and that a ratio of sulfur to selenium of 2.5:1 reduced selenium toxicity to a ratio of nearly $40: 1$. Shrift (1954) reported that the selenium content of the alga, Chlorella vulgaris, decreased as the external $\mathrm{SO}_{4}$ concentration was raised and remained constant at any one ratio of sulfur to selenium even though the external $\mathrm{SeO}_{4}$ concentration was raised 16 times. Stoklasa $(1922 \mathrm{a}, \mathrm{b})$, working with radioactive elements, demonstrated that 
radioactivity nullified the harmful effects of selenium in the germination of seeds and also in the production of chlorophyl. She reported also that the selenium taken up was reduced under the influence of light, and particularly under the influence of radioactivity, to a red colloidal substance which was not harmful to the vegetation. Thus the toxic effects were dissipated. Trelease and Beath (1949, p. 148) proved that tiny red granules found in the roots of plants poisoned by selenite were elemental selenium.

Similar red granules were observed in the stems and seeds of Astragalus preussi collected in the Yellow Cat area and grown in the experimental garden. The paucity of chlorosis near the Yellow Cat deposits suggests that the selenium is reduced in the plants in the presence of excessive sulfur and radioactivity and that the selenium is therefore harmless to the plants' growth.

Selenium is distributed in various parts of a plant according to species, phase of development, and physiological condition (Trelease and Beath, 1949, p. 152). Although the tops of a plant usually contain more selenium than the roots, Trelease and Beath found that the roots of Oonopsis condensata and Stanleya pinnata contained as much or more selenium than the tops. In controlled plot experiments and in plant collections from the Yellow Cat area, the following selenium contents (table 26) for tops and roots were found:

TABLE 26.-Selenium content, in parts per million, in the ash of various parts of several species of plants

[Analysts: J. H. McCarthy and J. W. T. Meadows. Laboratory numbers are shown in table 16]

\begin{tabular}{|c|c|c|c|}
\hline Species & Tops & Roots & Fruits \\
\hline $\begin{array}{l}\text { Yucca harrimaniae } \\
\text { Astragalus pattersoni } \\
\text { Do } \\
\text { Do } \\
\text { Do } \\
\text { Sphaeralcea parviflora } \\
\text { Grindelia aphanactis } \\
\text { Stanleya pinnata: } \\
\text { Young stems } \\
\text { Old stems } \\
\text { Allium sp. }\end{array}$ & $\begin{array}{r}80 \\
370 \\
3,330 \\
12,000 \\
5,710 \\
1,600 \\
2,600 \\
400 \\
310 \\
3,000\end{array}$ & $\begin{array}{r}80 \\
47 \\
5,000 \\
13,000 \\
4,500 \\
600 \\
810 \\
-370\end{array}$ & \\
\hline
\end{tabular}

Apparently no rule can be formulated in regard to selenium concentration in tops versus roots; even in an individual species, contents may change depending upon availability of the selenium. The fruits, however, seem to contain the largest accumulations of selenium (Trelease and Beath, 1949, p. 153; Taboury and Manceau, 1946). 


\section{ACCUMULATOR AND INDICATOR PLANTS}

Plants in the Yellow Cat area accumulate large quantities of selenium, and, for this reason, grazing is prohibited by Range Plant Management in most of the area. Thus absorption of large quantities of selenium by particular plant species is significant not only to the plant physiologist but also to the animal nutritionist; in fact the discovery of selenium accumulator plants was made because of their effect on animals. The first written description of selenium poisoning in livestock was given in 1857 by Madison (1860), who described symptoms of a disease that was fatal to cavalry horses at Fort Randall, Nebr. Subsequently, the peculiar disease among domestic animals was described (Peters, 1904; Lipp, 1922) from various sections of the west, and it was called alkali disease owing to the apparent restriction of the disease to areas having certain soils. Franke (1934) determined in 1929 that a poison in the forage was involved, and Robinson (1933) isolated selenium as the poison. Nelson, Hurd-Karrer, and Robinson (1933) demonstrated that 1 ppm selenium in the soil appeared to have no effect on wheat, but when that wheat was fed to rats, the rats died. Diets of ground stems, leaves, and seeds of seleniferous buckwheat that had been grown in field cultures were also injurious or lethal to rats depending on the selenium content in the plants (Martin, 1936).

Discovery of chronic selenium poisoning in humans living downstream from mines in Guanajuato, Mex. (Byers, 1937); in horses, cattle, and hogs in Hawaii (Hance, 1938); and in livestock in Ireland, (Walsh and others, 1951) rapidly followed.

In the United States, toxic areas in 10 counties of Montana, in Nebraska and South Dakota largely on the Pierre Shale; and in Utah on sandstone of the Morrison Formation were subsequently studied (Franke and others, 1934; Byers, 1935, 1936; Byers and Knight, 1935; Byers, Miller, Williams, and Lakin, 1938; Williams, Lakin, and Byers, 1940, 1941; Lakin, 1948).

Now that the effects of selenium on animals and on humans and the need for detailed knowledge of toxic areas have been shown, the concentrations in plants that are responsible for deleterious effects on health will be considered. An Irish scientist first demonstrated that plants have an ability to absorb selenium from soils to which it has been added (Cameron, 1880). Because selenium analyses of plants and soils are tedious and time consuming, no definitive information on the occurrence of this element in plants was available until the University of Wyoming Agricultural Experiment Station staff began their investigations. The Wyoming group reasoned, rightly, that the toxicity of areas in the Northwest could be measured only by studying the uptake of selenium by plants themselves as the total 
selenium in the soil was no real clue as to what or where toxicities might develop. Their studies (Beath, 1937; Beath and others, 1934, 1935, 1937a, b, 1939, 1940, 1941), together with those of the South Dakota Agricultural Experiment Station (Moxon and others, 1938, 1939; Moxon and Olson, 1940), extended over a 6-year period and demonstrated conclusively that certain plant groups possessed the ability to accumulate selenium in enormous quantities. Accumulator plants also were shown to be able to convert inorganic selenium to an organic form that could be easily absorbed by wheat and grasses (Beath and others, 1935). Thus, it is dangerous to plow under a stand of selenium accumulator plants and then to sow grain in the same area. Certain species of Astragalus, and most species of Oonopsis, Xylorrhiza, and Stanleya contained unusual quantities of selenium wherever they were collected and grew only where the soil contained selenium (Trelease and Beath, 1949, p. 123). Other species collected large quantities of selenium where selenium was especially available in the soil, but the plants normally contained only insignificant amounts and were able to grow in soil containing only small amounts of selenium. A third group of plants absorbed only small quantities of selenium even when the selenium was available in a soluble form.

Many plants of the first two categories grow in the Yellow Cat area. These are listed in table 27 along with maximum contents of selenium

TABLE 27.-Selenium content, in parts per million, of primary and secondary accumulator plants in Yellow Cat area compared with maximum contents found in some species by other workers

[Laboratory numbers and analysts given in table 16]

\begin{tabular}{|c|c|c|c|c|}
\hline \multirow{2}{*}{ Species } & \multicolumn{2}{|c|}{ Yellow Cat area } & \multirow{2}{*}{$\begin{array}{l}\text { Maximum } \\
\text { contents } \\
\text { in dry weight, } \\
\text { found by other } \\
\text { workers }\end{array}$} & \multirow{2}{*}{ Reference } \\
\hline & In ash & $\begin{array}{l}\text { In dry } \\
\text { weight }\end{array}$ & & \\
\hline 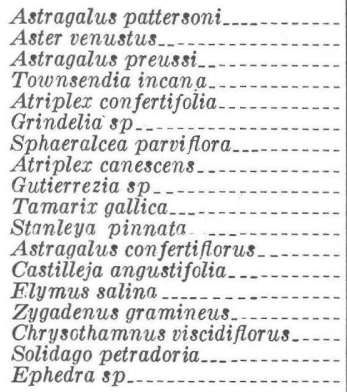 & $\begin{array}{r}46,000 \\
20,500 \\
11,300 \\
5,700 \\
5,500 \\
5,200 \\
4,500 \\
4,188 \\
3,800 \\
3,800 \\
3,120 \\
1,600 \\
1,310 \\
1,200 \\
1,100 \\
1,000 \\
520 \\
450\end{array}$ & $\begin{array}{r}6,000 \\
3,070 \\
1,130 \\
1,500 \\
1,260 \\
450 \\
300 \\
670 \\
230 \\
460 \\
500 \\
150 \\
275 \\
120 \\
110 \\
200 \\
80 \\
50\end{array}$ & $\begin{array}{r}8,512 \\
3,486 \\
4,188 \\
3 \text { (T. glabella) } \\
1,734 \\
293 \\
\text { (1) } \quad \\
477 \\
1,287\end{array}$ & $\begin{array}{l}\text { Trelease and Beath (1949, p. 156). } \\
\text { Beath and Eppson (1947). } \\
\text { Beath (1943). } \\
\text { Beath, Gilbert, and Eppson (1939). } \\
\text { Beath (1943). } \\
\text { Trelease and Beath (1949, p. 131). } \\
\text { Beath, Gilbert, and Eppson (1939). } \\
\text { Beath and Eppson (1947). } \\
\text { Beath (1943). } \\
\text { Beath, Gilbert, and Eppson (1941). } \\
\text { Do. } \\
\text { Beath (1943). } \\
\text { Holt and Greaves (1941). } \\
\text { Do. }\end{array}$ \\
\hline
\end{tabular}

1 Negative.

found in these plants both in this study and elsewhere. Very few selenium analyses were run during the investigation because of the 
complexity of the method. Despite the small number of analyses, it is nevertheless apparent that the absorption of selenium by plants in the Yellow Cat area is generally high. In addition to plants found by Beath (1943) to be selenium indicators and accumulators, the following plants were found to contain large amounts of selenium in the Yellow Cat area: Chrysothamnus viscidiflorus, Elymus salina, Sphaeralcea parviflora, Solidago petradoria, Ephedra gallica, Townsendia incana, and Zygadenus gramineus. Of these, Townsendia incana, shown in figure 8 seemed to have the restricted distribution

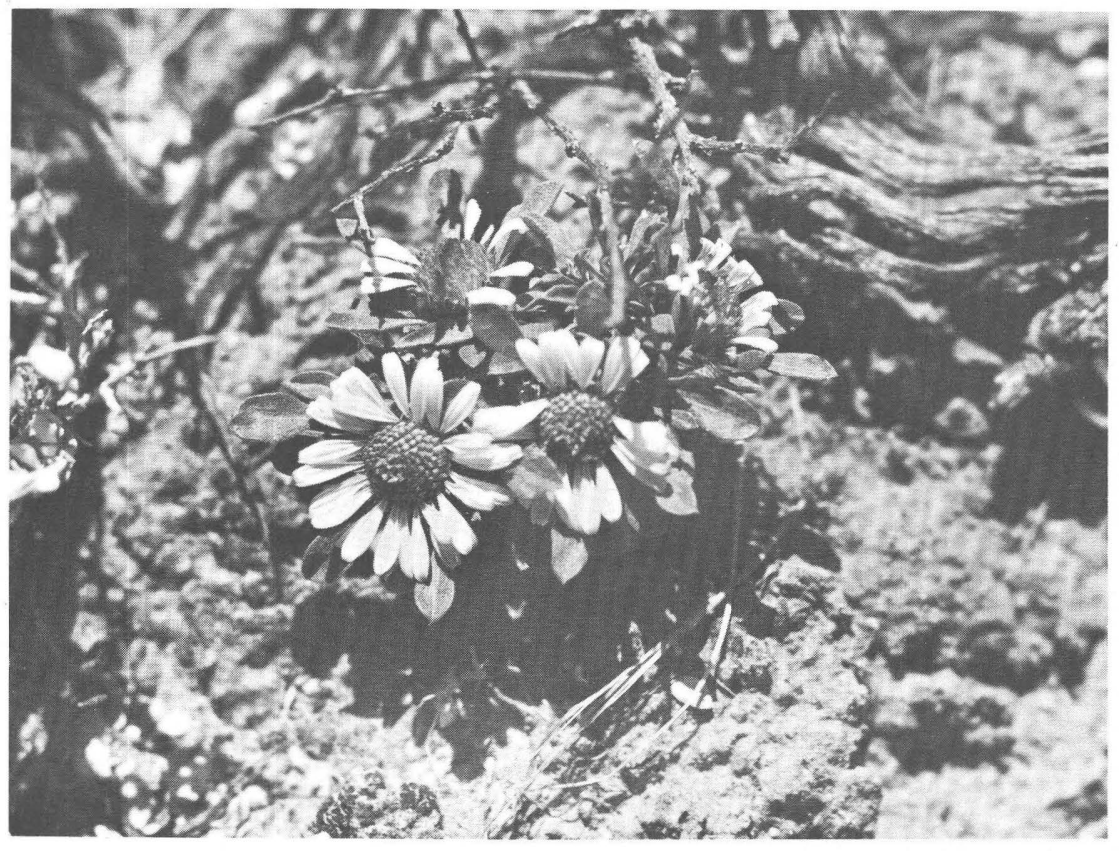

Figure 8.-Townsendia incana, a selenium concentrator in the Yellow Cat area.

and selenium content of an indicator or primary accumulator plant. Prospectors working in the McCoy group became very ill from tea brewed from the Ephedra plant. Possibly the ill effects were due to the plant's selenium content.

Trelease (1942) devised a simple germination test to differentiate between accumulator and nonaccumulator species of Astragalus. By 
germinating the various species of seeds in solutions containing $1 / 3,1$, 3 , and $9 \mathrm{ppm}$ sodium selenite and measuring the length of roots after 4 days, he was able to show a physiological differentiation of Astragalus species into accumulators and nonaccumulators (Trelease and Beath, 1949, p. 20). Species of the first group can be used as indicators of seleniferous soil, for they require much selenium to grow. Of the 25 species tested, Astragalus pattersoni (fig. 9), A. preussi (fig. 10), and $A$. confertiflorus, all of which grow in the Yellow Cat area, reached positively to the selenium test. All three were found to accumulate selenium and to be reliable indicators of seleniferous ground. The use of selenium indicator plants in prospecting for uranium ores in the Yellow Cat area was proposed by Beath (1943) and by Beath, Hagner, and Gilbert (1946). For these reasons, these species were chosen for this particular study and were eventually established as reliable indicators of uranium ore.

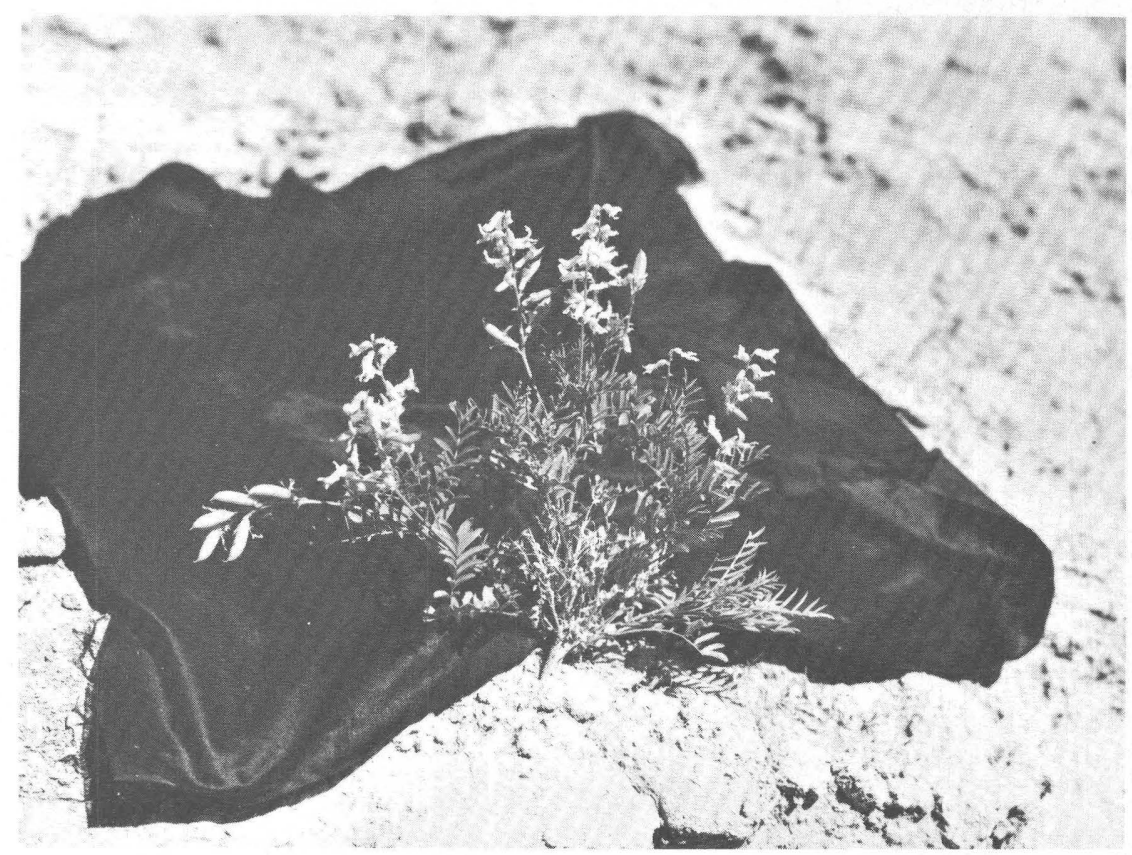

FIGURE 9.-Astragalus pattersoni, selenium indicator used successfully in uranium prospecting in Yellow Cat area. 


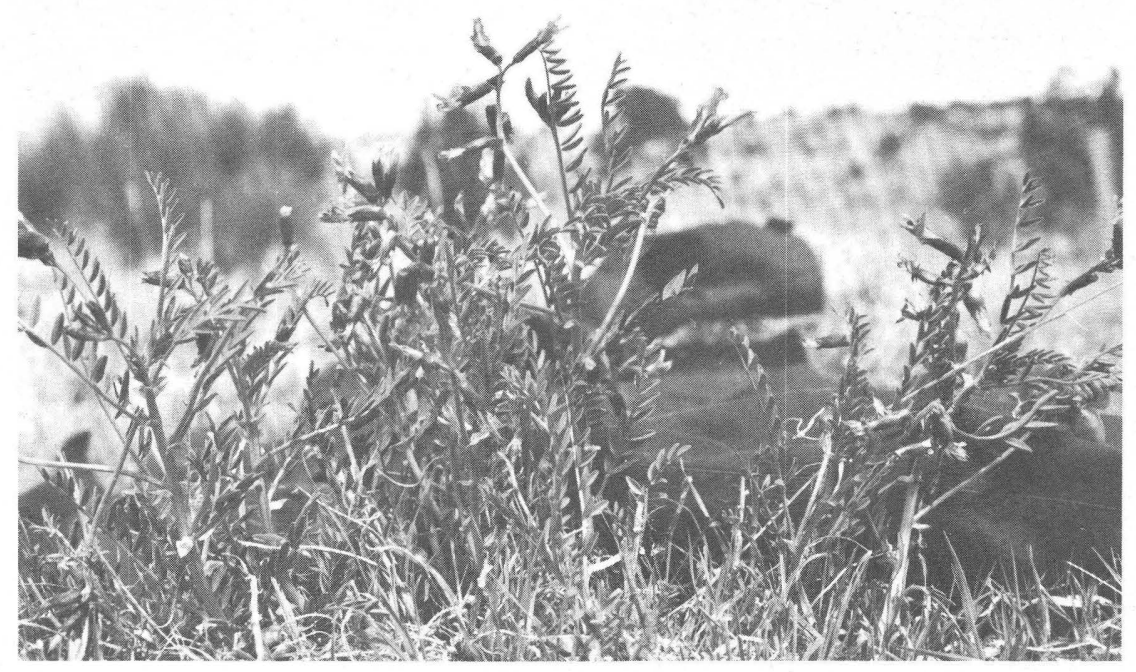

Figure 10.-Astragalus preussi, selenium indicator used successfully in uranium prospecting in Yellow Cat area.

\section{OTHER ELEMENTS}

Samples of several plant species were analyzed also for lead, copper, nickel, calcium, phosphorus, and rhenium. Complete qualitative spectrographic analyses were run in the first year of the project, but the results, which were reported only in order of magnitude, were of no value in prospecting. A few semiquantitative spectrographic analyses reported in five divisions per order of magnitude were run in the Geological Survey mobile spectrographic laboratory in 1958. These analyses adequately show the differences in absorption by the various plant species from mineralized and barren ground. Mean values for copper and nickel are summarized in table 28, and all analyses for copper, nickel, and rhenium are given in table 29 .

TABLE 28.-Average copper and nickel contents, in parts per million, in the ash of the above-ground parts of plants in the Yellow Cat area

\begin{tabular}{|c|c|c|}
\hline & Copper & Nickel \\
\hline Mineralized & 110 & 35 \\
\hline Unmineralized & 64 & 18 \\
\hline Average content in plants as reported in literature & 140 & 26 \\
\hline
\end{tabular}


TABLE 29.-Copper, nickel, and rhenium, in parts per million, in the ash of a few plants from Yellow Cat area

[Parts of plants sampled are aerial except where otherwise noted. Ground: U, unmineralized; $M$ mineralized. Analysts: Uteana Oda and E. F. Cooley, Cu, Ni; J. C. Hamilton, Re. nd=not determined]

\begin{tabular}{|c|c|c|c|c|c|}
\hline Laboratory No. & Species & Ground & $\mathrm{Cu}$ & $\mathrm{Ni}$ & $\mathbf{R e}$ \\
\hline \multicolumn{6}{|c|}{ Trees and shrubs } \\
\hline 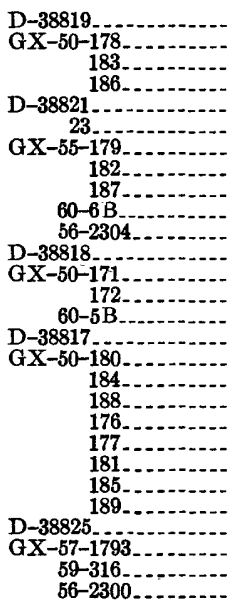 & 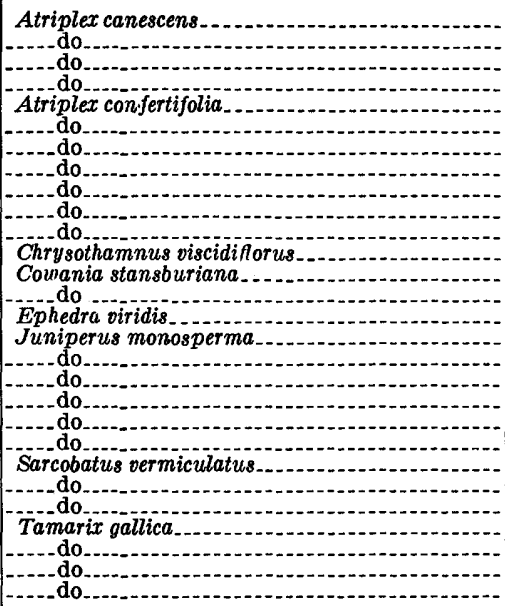 & $\begin{array}{l}\mathbf{U} \\
\mathbf{U} \\
\mathbf{U} \\
\mathbf{U} \\
\mathbf{M} \\
\mathbf{U} \\
\mathbf{U} \\
\mathbf{U} \\
\mathbf{U} \\
\mathbf{M} \\
\mathbf{M} \\
\mathbf{U} \\
\mathbf{M} \\
\mathbf{U} \\
\mathbf{M} \\
\mathbf{U} \\
\mathbf{U} \\
\mathbf{U} \\
\mathbf{U} \\
\mathbf{M} \\
\mathbf{M} \\
\mathbf{U} \\
\mathbf{U} \\
\mathbf{U} \\
\mathbf{M} \\
\mathbf{M} \\
\mathbf{M} \\
\mathbf{M}\end{array}$ & $\begin{array}{r}40 \\
\text { nd } \\
\text { nd } \\
\text { nd } \\
20 \\
10 \\
\text { nd } \\
\text { nd } \\
\text { nd } \\
30 \\
40 \\
60 \\
\text { nd } \\
\text { nd } \\
30 \\
60 \\
\text { nd } \\
\text { nd } \\
\text { nd } \\
\text { nd } \\
\text { nd } \\
\text { nd } \\
\text { nd } \\
\text { nd } \\
60 \\
300 \\
150 \\
80\end{array}$ & $\begin{array}{r}6 \\
20 \\
10 \\
10 \\
<6 \\
\text { nd } \\
10 \\
20 \\
10 \\
15 \\
\text { nd } \\
6 \\
20 \\
40 \\
15 \\
6 \\
20 \\
20 \\
20 \\
40 \\
20 \\
20 \\
60 \\
30 \\
20 \\
\text { nd } \\
\text { nd } \\
\text { nd }\end{array}$ & $\begin{array}{c}\text { nd } \\
\text { nd } \\
\text { nd } \\
\text { nd } \\
\text { nd } \\
\text { nd } \\
\text { nd } \\
\text { nd } \\
\text { nd } \\
\text { 300 } \\
\text { nd } \\
\text { nd } \\
\text { nd } \\
\text { nd } \\
\text { 150 } \\
\text { nd } \\
\text { nd } \\
\text { nd } \\
\text { nd } \\
\text { nd } \\
\text { nd } \\
\text { nd } \\
\text { nd } \\
\text { nd } \\
<50 \\
<50 \\
\text { nd }\end{array}$ \\
\hline
\end{tabular}

Herbs

\begin{tabular}{|c|c|c|c|c|c|}
\hline 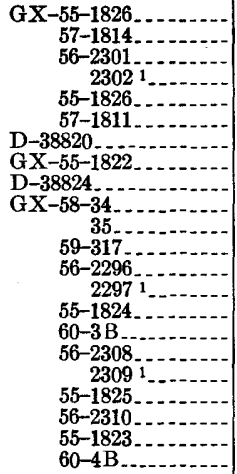 & 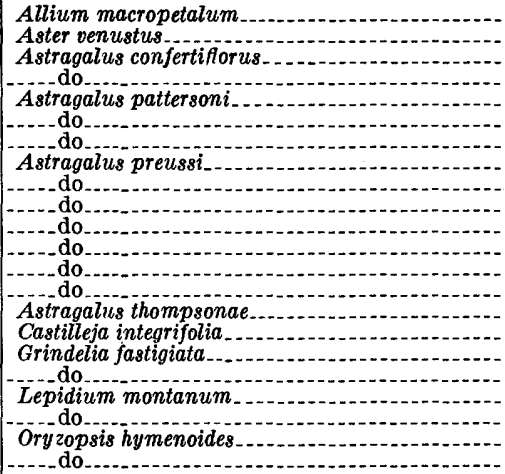 & $\begin{array}{l}\mathbf{M} \\
\mathbf{M} \\
\mathbf{M} \\
\mathbf{M} \\
\mathbf{M} \\
\mathbf{M} \\
\mathbf{M} \\
\mathbf{M} \\
\mathbf{M} \\
\mathbf{M} \\
\mathbf{M} \\
\mathbf{M} \\
\mathbf{M} \\
\mathbf{U} \\
\mathbf{M} \\
\mathbf{M} \\
\mathbf{M} \\
\mathbf{M} \\
\mathrm{U}\end{array}$ & $\begin{array}{r}70 \\
30 \\
700 \\
150 \\
70 \\
30 \\
40 \\
70 \\
60 \\
100 \\
200 \\
150 \\
100 \\
1,500 \\
50 \\
150 \\
150 \\
300 \\
50 \\
60 \\
50 \\
100\end{array}$ & $\begin{array}{l}\text { nd } \\
\text { nd } \\
\text { nd } \\
\text { nd } \\
\text { nd } \\
\text { nd } \\
<6 \\
\text { nd } \\
200 \\
30 \\
30 \\
\text { nd } \\
\text { nd } \\
\text { nd } \\
\text { nd } \\
20 \\
\text { nd } \\
\text { nd } \\
\text { nd } \\
\text { nd } \\
\text { nd } \\
15\end{array}$ & $\begin{array}{r}<50 \\
<50 \\
<50 \\
<50 \\
\text { nd } \\
70 \\
\text { nd } \\
\text { nd } \\
\text { nd } \\
\text { nd } \\
\text { nd } \\
150 \\
\text { nd } \\
<50 \\
\text { nd } \\
\text { nd } \\
150 \\
<50 \\
\text { nd } \\
\text { nd } \\
\text { nd } \\
\text { nd }\end{array}$ \\
\hline
\end{tabular}

1 Roots of same plant as in preceding sample.

Lead analyses were made of 17 plant species to discover whether radiogenic lead resulting from radioactive decay made a detectable difference on the lead absorbed by plants near uranium deposits. In general, these plants in the Yellow Cat district contain less lead than do average plants. Aerial parts of the plants over mineralized ground contained an average of $23 \mathrm{ppm}$, and those over unmineralized ground contained only $16 \mathrm{ppm}$; a reverse relationship held for the 
roots: those in mineralized ground contained $25.5 \mathrm{ppm}$ and those in unmineralized ground, $31.5 \mathrm{ppm}$. The total lead content for tops plus roots is then nearly identical. This suggests that in the more acid mineralized ground, more lead is in solution and therefore is transported to the tops of the plant; in unmineralized ground the lead is removed from the clays and is fixed in the roots by base exchange. It was not possible to determine whether or not there is differential uptake of radiogenic lead from mineralized ground. Unusually large amounts of lead were found in Ephedra viridis (Mormon tea), Juniperus monosperma, and in Fraxinus anomala (single-leaf ash), but there was no marked accumulation in plants compared to soils.

The nickel content of the plants rooted in ore is more than twice the content of plants rooted in barren ground, but the average content was severely affected by an unusually large amount of nickel in a sample of Astragalus preussi that was collected from a partially mineralized bentonitic blue clay. Generally the nickel values were not sufficiently large to be useful in prospecting.

The copper content of the above-ground parts of the plants in the Yellow Cat area is considerably lower than that for average plants, as copper is not readily available in an alkaline environment or, at least, is not readily transported to the upper part of the plant. The only root that was analyzed contained $1,500 \mathrm{ppm}$. Plants growing in mineralized ground average more than twice as much copper as plants growing in unmineralized ground. The Astragalus preussi plants that were growing in the excavated cut of the Little Pittsburg 3 mine exhibited a curious coior change: the flowers of some plants were nearly white instead of the normal cerise-purple. Complete spectrographic and chemical analyses of Astragalus preussi were run to find the cause. The results are given in table 30 .

The analyses presented in table 30 are the most complete of those run during the investigation and probably best show the trace-element content of these plants. Nevertheless, the cause for the difference in coloration is not readily apparent therefrom. The plants contained equal amounts of lead, manganese, nickel, molybdenum, titanium, and magnesium. Although both forms contained considerably more uranium, vanadium, selenium, and molybdenum than an average legume, they contained less-than-average amounts of lead, zinc, boron, barium, iron, and manganese. The white chlorotic form contained more copper, selenium, cobalt, boron, iron, silica, barium, and less vanadium than the normal purple form. The increase in selenium can be disregarded because some normally colored plants of this species contained more than 1 percent selenium in the ash. The decrease in vanadium is probably also not significant because several other samples with normal coloration contained less vanadium. The necessity for a 
TABLE 30.-Trace elements, in parts per million, in the ash of Astragalus preussi compared with those in the ash of average legumes

[Analysts: A. P. Marranzino, C. E. Thompson, and E. F. Cooley]

\begin{tabular}{|c|c|c|c|}
\hline Element & $\begin{array}{l}\text { Normal purple } \\
\text { flowers } \\
\text { (GX-58-34) }\end{array}$ & $\begin{array}{l}\text { Chlorotic white } \\
\text { flowers } \\
\text { (GX-58-35) }\end{array}$ & $\begin{array}{l}\text { A verage com- } \\
\text { position of } \\
\text { legumes } 1\end{array}$ \\
\hline $\begin{array}{l}\text { Uranium } \\
\text { Vanadium } \\
\text { Selenium } \\
\text { Molybdenum } \\
\text { Lead } \\
\text { Copper } \\
\text { Nickel } \\
\text { Zine } \\
\text { Cobalt } \\
\text { Chromium } \\
\text { Boron } \\
\text { Barium } \\
\text { Zirconium } \\
\text { Titanium } \\
\text { Strontium } \\
\text { Silica } \\
\text { Iron } \\
\text { Magnesium } \\
\text { Manganese }\end{array}$ & $\begin{array}{r}12 \\
300 \\
330 \\
70 \\
<10 \\
100 \\
30 \\
<200 \\
<10 \\
<20 \\
150 \\
500 \\
15 \\
300 \\
>10,000 \\
20,000 \\
1,500 \\
30,000 \\
500\end{array}$ & $\begin{array}{r}8 \\
150 \\
633 \\
70 \\
10 \\
200 \\
30 \\
<200 \\
20 \\
<20 \\
200 \\
700 \\
50 \\
500 \\
10,000 \\
50,000 \\
2,000 \\
30,000 \\
500\end{array}$ & $\begin{array}{r}0.8 \\
10 \\
<4 \\
20 \\
19 \\
150 \\
22 \\
570 \\
5 \\
6.5 \\
370 \\
1,420 \\
22 \\
185 \\
620 \\
25,000 \\
5,000 \\
50,700 \\
2,000\end{array}$ \\
\hline Percent of ash in plant & 15 & 13 & 7 \\
\hline
\end{tabular}

1 Calculated from 2,667 analyses in U.S. Geol. Survey files and reported in the literature.

copper-molybdenum balance in plants has been pointed out by severa workers (Haas and Brusca, 1953; Robinson and Dever, 1956) and may hold the clue in this circumstance. A molybdenun-to-copper ratio of about $1: 1$ seems to be characteristic of the normal deeppurple form (in all 4 samples analyzed for both copper and molybdenum), whereas a ratio of $1: 3(70 \mathrm{ppm}$ molybdenum to $200 \mathrm{ppm}$ copper) is characteristic of the abnormal white form.

A few plants were analyzed for calcium and phosphorus (table 31 ); they contained an average 13 percent calcium and 0.7 percent phosphorus. Both of these values are a little lower than is generally found in plants. Possibly this discrepancy accounts for the increased abundance of calcium- and phosphorus-consuming plants near carnotite deposits where these elements are somewhat more available.

The analyses for rhenium shown in table 29 are probably the first analyses for this element that have ever been made on plant ash. They were run by Myers and Hamilton (1960) on an emission spectrograph in conjunction with a study being made by Myers on the distribution of rhenium in soils and rocks. Plant samples from the Yellow Cat area were chosen because of their high molybdenum content. Of the 15 samples from the Yellow Cat area that were analyzed, rhenium was detected in 5 , all of which were collected from a small 
TABLE 31.-Calcium and phosphorus, in percent, of the ash of a few plants in the Yellow Cat area

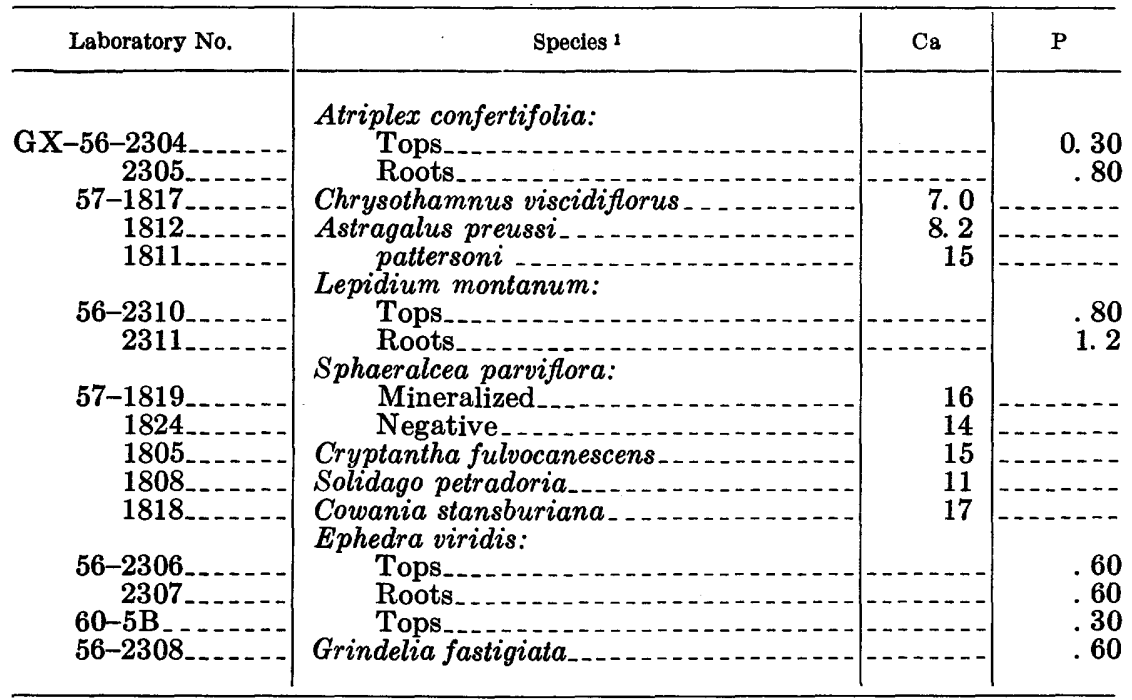

1 Analysts and additional chemical analyses for these samples are given in table 16.

schroeckingerite deposit in the McCoy group. These analyses showed $70 \mathrm{ppm}$ in Astragalus pattersoni, $150 \mathrm{ppm}$ in $A$. preussi, $150 \mathrm{ppm}$ in Grindelia fastigiata, $300 \mathrm{ppm}$ in Atriplex confertifolia, and $150 \mathrm{ppm}$ in Ephedra viridis. No rhenium (less than $50 \mathrm{ppm}$ ) could be detected in the schroeckingerite. Additional analyses have revealed the presence of 50-300 ppm rhenium in Eriogonum sp. and Astragalus pattersoni from the Gypsum Valley district. In both these areas the calcium and molybdenum contents are abnormally high. No rhenium was detected in plants growing on barren gypsum beds in Paradox Valley or in plants collected from schroeckingerite deposits near Wamsutter, Wyo., where the calcium content is high but the molybdenum content is very low.

A study of the plant distribution, state of health, and metal content in the Yellow Cat area has led, then, to the following conclusions. First, macroscopic symptoms of physiological disturbance were surprisingly few and were restricted generally to plants growing in disturbed ground; use of these symptoms was dismissed as a method of prospecting. Second, certain species of plants were more abundant on mineralized ground than on barren ground, and at least three or four species appeared to grow only on mineralized ground that contained a considerable amount of selenium and uranium. This distribution could be mapped as an aid in locating and outlining mineralized ground. Third, plants growing on mineralized ground contained more uranium and other trace elements than those growing on un- 
mineralized ground. Anomalous uranium in deep-rooted trees growing in mineralized ground should be useful in prospecting. These findings could be applied in a new search for ore in the Yellow Cat district.

\section{COMBINED EFFECT OF ELEMENT EXCESSES ON PLANT DISTRIBUTION}

The occurrence and relative abundance of the various species of plants around the uranium deposits in the Yellow Cat area are regulated by the tolerance of individual species for the elements available in the ore environment and for the radiation present in the soil near the roots during the life of the plants. Elements that are more available in the carnotite ores than in the surrounding unmineralized sandstone may encourage some species and deter others. The studies that were made in the Yellow Cat area of the plant societies tolerant of uraniferous ground have been discussed in the section on uranium. Those plant species that had both increased and decreased populations on mineralized ground are listed in table 19.

Information acquired from experimental studies, chemical analyses, and observation suggests that the distribution and growth habits of plants may be influenced or controlled by the chemical components shown in table 32 . In plot experiments, selenium, sulfur, calcium, and phosphorus were more readily absorbed by plants where carnotite

TABLE 32.-Indicator plants and the chemical components that may influence their distribution

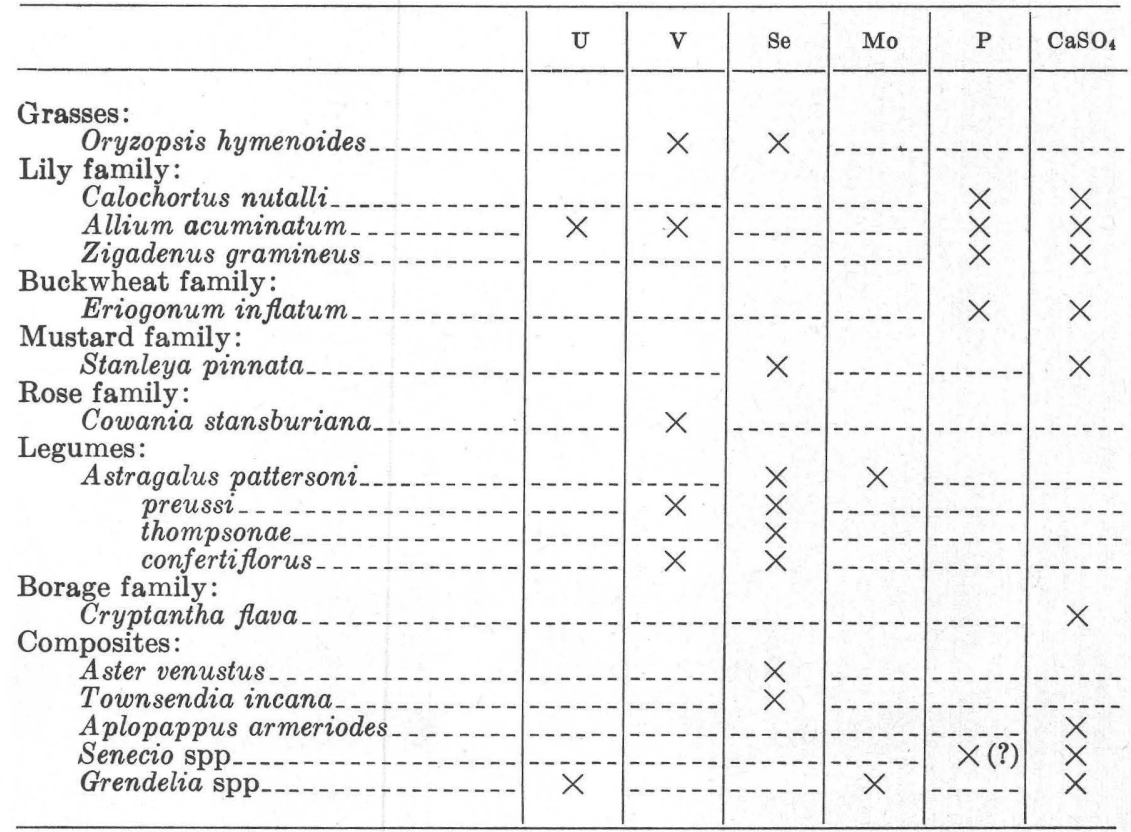


was added to the soil; uranium and vanadium were more readily absorbed in the presence of selenium and sulfur. Many ore deposits contain gypsum-derived from the oxidation of sulfide-above the water table. The chemical controls may thus be a combination of elements. No single calcium- or sulfur-consuming plant can be considered indicative of mineralized ground because many of the plants are ubiquitous roadside weeds; but a dense population of several species of plants mixed with selenium indicator species may be significant in prospecting. The ores on Memphis Hill, in Pittsburg Park, and in the Cactus Rat group are especially gypsiferous. These areas are covered in early May by a magnificent flowering carpet of sulfur and calcium indicator plants.

\section{FIELD MAPPING AND SAMPLE COLLECTION IN TRIAL PROSPECTING PROGRAM}

\section{MAPPING OF INDICATOR PLANTS}

The distribution of eight selenium indicators-Astragalus pattersoni, A. preussi, A. thompsonae (fig. 11), A. confertiflorus, $A$. missouriensis, Stanleya pinnata, Aster venustus, and Oryzopsis hymenoides-was mapped through out the Yellow Cat area in 1949 and 1950, after the

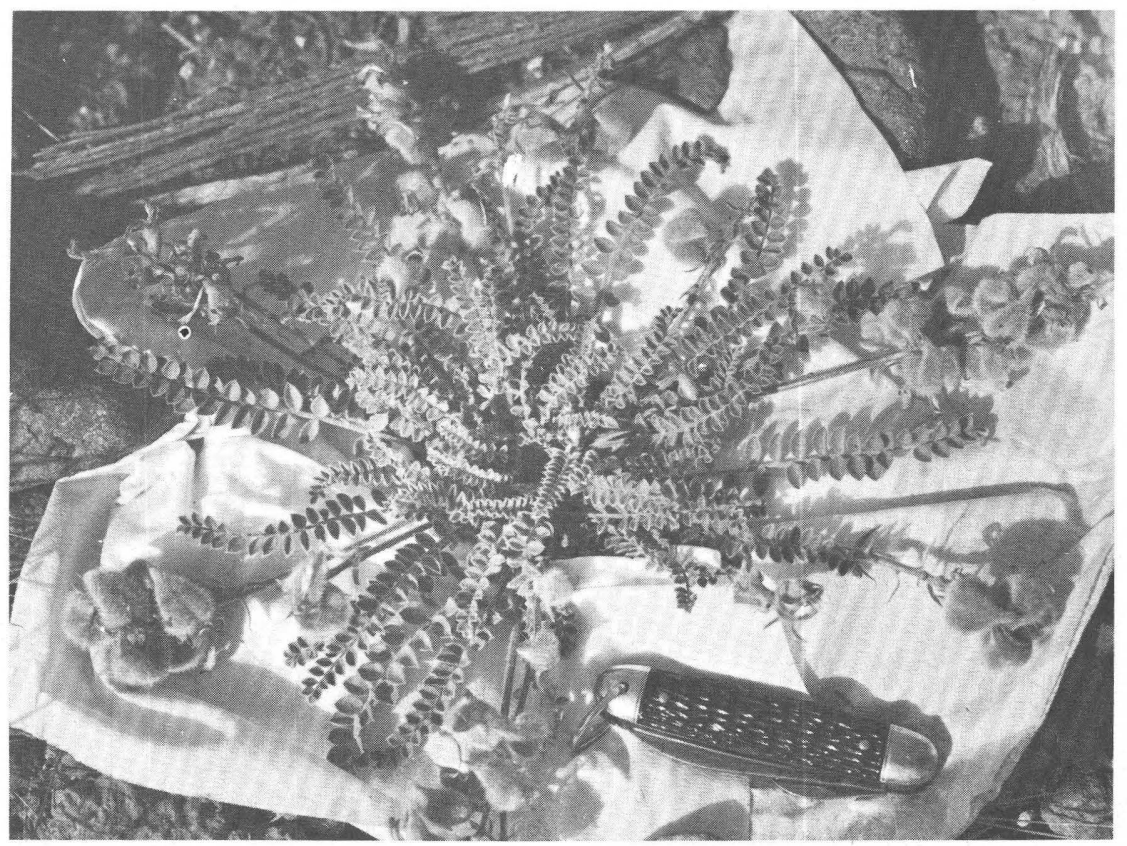

FIGURE 11,-Astragalus thompsonae, selenium indicator useful in uranium prospecting but difficult to find in field mapping. 
preliminary studies described in the previous section has shown a close relation between selenium and uranium in mineralized ground. The occurrence of these plants was recorded by symbols on 3 maps (scale of $1 \mathrm{in} .=500 \mathrm{ft}$ ) that represented an area of 6 square miles. Plants in the McCoy group of claims were mapped on an enlarged scale of 1 inch $=100$ feet.

During the mapping, certain indicators were found to be of little value in outlining mineralized ground for the following reasons:

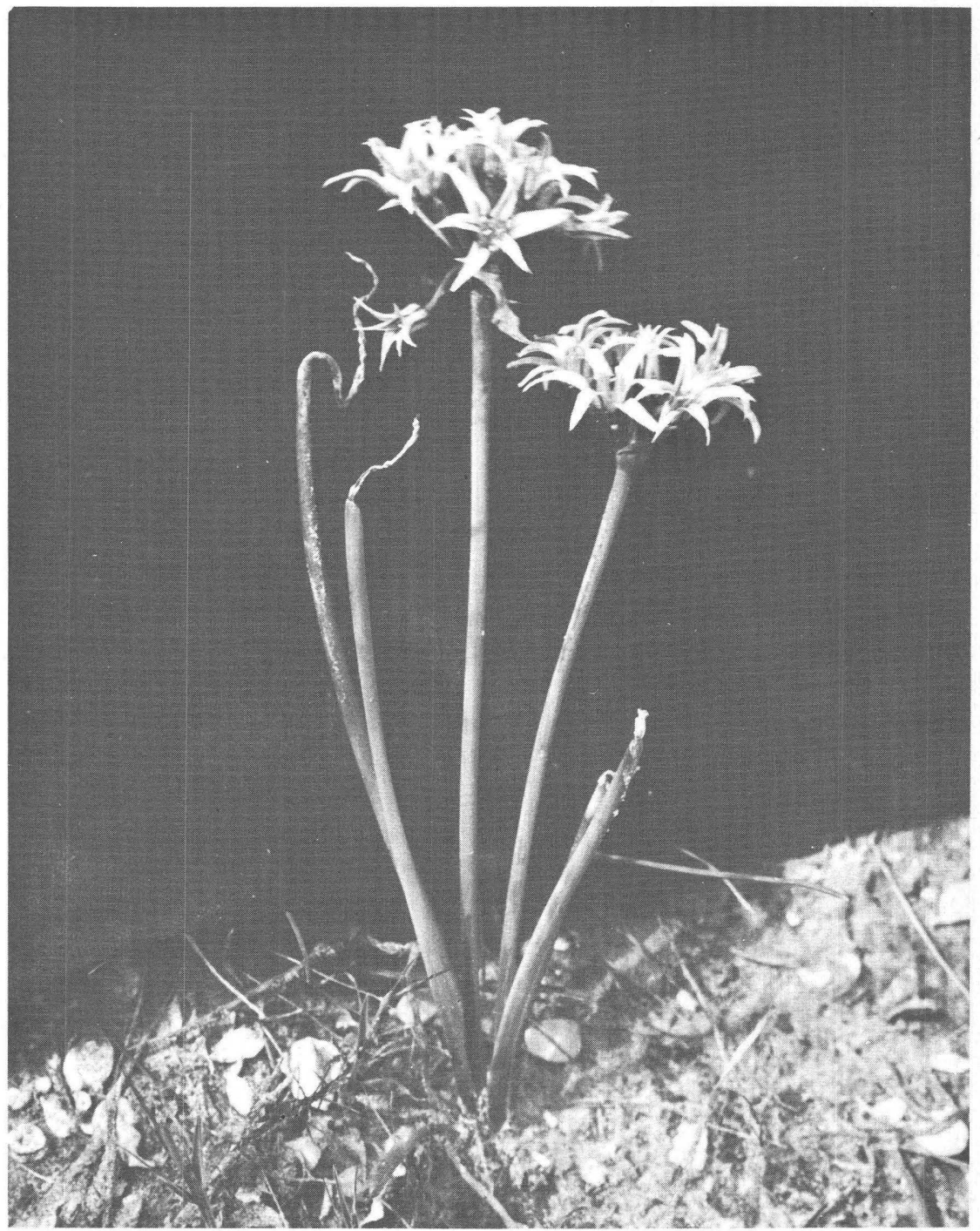

FIgURE 12.-Allium acuminatum, sulfur concentrator useful in prospecting for shallow uranium deposits in Yellow Cat area. 
1. Astragalus missouriensis required very small amounts of selenium and was apparently unable to grow where selenium was concentrated to any degree in the soil.

2. Aster venustus and Oryzopsis hymenoides grew only on clay alluvial soils or dumps and hence were not indicators of ore in place.

Final maps were therefore made, and areas of botanical favorability were outlined, on the distribution of Astragalus pattersoni, A. preussi, $A$. confertiflorus, and Stanleya pinnata. The maps were filed with the U.S. Atomic Energy Commission in 1951 in advance of drilling. The distribution of Allium acuminatum (fig. 12) and Eriogonum inflatum was later mapped on Memphis Hill and in Pittsburg Park where the plants seemed to be related to mineralized ground. The occurrence of these six species is shown on plate 3 of this report, Detailed distribution in the McCoy group is shown on plate 2 .

\section{COLLECTION OF PLANTS FOR URANIUM ANALYSES}

Trees and shrubs in several parts of the Yellow Cat area were sampled to test plant analysis as a method of prospecting. Branch tips of Atriplex confertifolia or shadscale, a xerophyte, were collected at 50-foot intervals along traverses laid out by alidade in several directions from the mineralized southeast corner of Yellow Cat Mesa. Ground water is not available at a shallow depth and hence there are no phreatophytes present; the roots of shadscale, a xerophyte penetrate to the ore horizon which is less than 10 feet from the ground surface. The uranium contents are shown on plate 1 .

The McCoy group was chosen for a second sampling program because the ore-bearing sandstone is an aquifer and because the bench has a dense cover of junipers that tap this perched water table. Samples were collected at 50-foot intervals along several traverses. The uranium and vanadium contents of both branch tips and roots of many trees were determined. The uranium content of the branch tips provided the most constant reflection of the position of ore at depth, and therefore only branch-tip analyses are shown on plate 2 . Shadscale was sampled where juniper was not available. Samples were collected along short traverses in six other parts of the district to obtain background information or to prospect for extensions of favorable ground. Cowania stansburiana, which is locally known as vanadium bush, was collected on a mesa that was believed to be unmineralized to test the value of the plant as an indicator of uranium; the location of the collecting sites and the uranium values are shown on plate 3. The results of the plant-analysis studies were evaluated and were used along with the indicator-plant data in outlining botanically favorable areas in advance of drilling. These broad areas of botanical favorability were later demonstrated to be too gross to 
be useful as drilling guides, and they thus are not discussed in this report; the location of actual patches of indicator plants and of specific trees that contain anomalous uranium must be used in prospecting for ore.

\section{PHYSICAL EXPLORATION IN THE YELLOW CAT AREA}

\section{DRILING BY PRIVATE INDUSTRY}

Not all the plant prospecting was done in advance of drilling; the Red Vanadium claims of the McCoy group were explored for vanadium by drilling by the U.S. Bureau of Mines in 1943, during World War II. The location of the holes is shown on plate 2. An ore body that was discovered just north of the McCoy cabin in 1943 has subsequently been mined, but the ore has not been as rich in uranium as was expected.

In 1951 the U.S. Vanadium Corp. drilled in these same claims and also in the area south of the claims (pl. 2). Another ore body was found southwest of the known deposits. Ore has been found more recently in areas believed from plant data to be anomalous, but the company information is not available.

The map (pl. 3) shows all plant information in detail, nearly all the drilling locations, and the areas of geologic favorability that were developed during the drilling program.

\section{GEOLOGICAL SURVEY DRILLING PROGRAM}

From October 9, 1951, to November 23, 1954, private companies, under four separate contracts to the Geological Survey, diamonddrilled 165,505 feet in 995 holes and wagon-drilled 54,973 feet in 726 holes in the Yellow Cat area (Mobley and Santos, written communication, 1956). Of these holes, 453 were drilled either west or east of the area of plant mapping and have been excluded from the statistical evaluation of plant prospecting discussed in a later section of this report. In general, holes were drilled to penetrate the bed 4 sandstone, the lowest major ore zone; areally, drilling was limited to the area of Salt Wash outcrop where the base of the bed 4 sandstone is within 300 feet of the surface. For geologic information, diamonddrill holes were made according to a widely spaced grid pattern of either 500 - or 1,000-foot centers over the entire area. From the drill-hole data, maps were drawn to show geologically favorable areas (pl. 3). Moderately spaced holes (200-foot centers) were drilled to search for ore deposits in ground determined to be geologically favorable, and closely spaced holes (50- or 100-foot centers) were drilled to outline deposits. About 290 holes were drilled on the basis of botanical information alone. 
Each sandstone unit penetrated in drilling was classified according to geologic favorability and to the amount of mineralized rock present. Favorability was determined from geologic criteria known to accompany the localization of ore (Weir, 1952). The criteria considered were the thickness and color of the ore-bearing sandstone, the character of the altered mudstone associated with the ore-bearing sandstone, and the abundance of carbonaceous material in the sandstone. Rock having an approximate grade of 0.02 percent or more $\mathrm{U}_{3} \mathrm{O}_{8}$ and 0.1 percent or more $\mathrm{V}_{2} \mathrm{O}_{5}$ was considered to be mineralized. One foot or more of rock assaying at least 0.10 percent $\mathrm{U}_{3} \mathrm{O}_{8}$ or 1.0 percent $\mathrm{V}_{2} \mathrm{O}_{5}$ was considered to be ore.

Of the 1,268 holes drilled for the Geological Survey in the parts of the Yellow Cat area under study, 81 penetrated rock of ore grade, 216 penetrated mineralized rock that was considered to be less than ore grade, and the remainder were drilled in barren ground.

\section{EVALUATION OF BOTANICAL METHODS OF PROSPECTING}

\section{INDICATOR-PLAN'T METHOD}

Drill-hole data provide complete coverage of the 6 square miles of the Yellow Cat area that was mapped botanically, so a large number of comparisons are possible. Plant-indicator information can be compared with the extent of the ground that was found by geologic criteria to be farorable for ore, with the areal extent of mineralized rock and ore that was penetrated in drilling, and with the rariations in depth at which the mineralized rock was found. The information acquired on the effectiveness of the various species that were mapped is also significant.

\section{COMPARATIVE EFFECTIVENESS OF INDICATOR SPECIES}

A wide variation in the effectiveness of the various indicator species became apparent during the mapping. Stanleya pinnata, particularly, seemed to be intolerant of mineralized ground although it is common along the drainage from areas containing mines and prospects. Astragalus confertiflorus was more common on outcrops of blue mudstone associated with the ores than on mineralized sandstone. These differences were emphasized when the distribution of the six species was compared with the results of the drilling as shown in table 33. Astragalus pattersoni and A. preussi are undoubtedly the most reliable indicators of mineralized ground, and gypsum indicators are useful guides where the ore occurs at a shallow depth. The two 
$\mathrm{T}_{\mathrm{ABL}} \mathrm{33}$ 33.-Effectiveness of various plant species as indicators of uranium in the Yellow Cat area

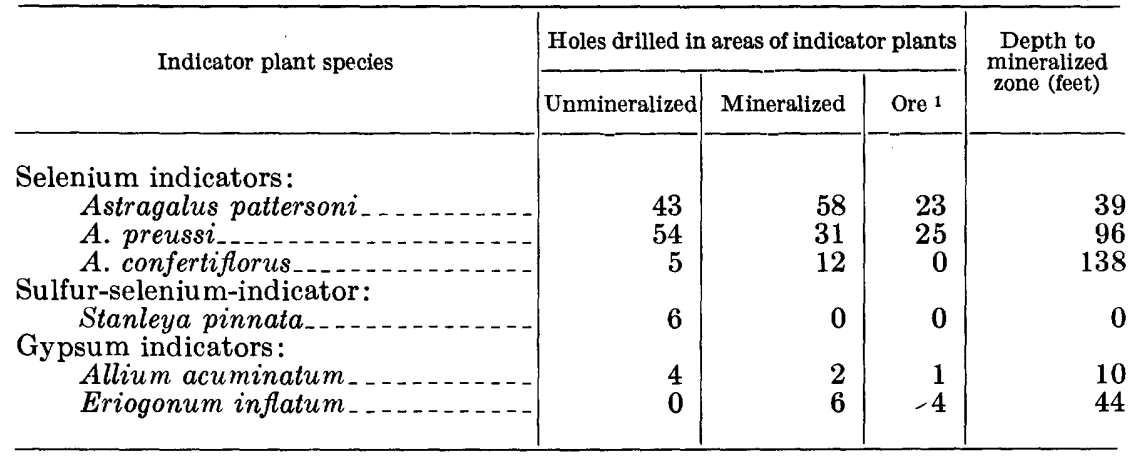

1. Overlap of species at certain holes.

Astragalus species are both effective guides in prospecting; Astragalus pattersoni is perhaps somewhat more so, as the species was found around twice as many mineralized holes as around barren holes.

The difference in areal distribution of the two species in the district may be related to depth and degree of oxidation of the ore. Astragalus preussi is much more common in the western part of the area on the original Yellow Cat claims where the ore was found in sandstone beds 1-4 (p. 14) at various drilling depths, and $A$. pattersoni is much more common in the central (Cactus Rat) and eastern (McCoy and Flattop) parts of the area where the ore is comparatively shallow. The presence of Astragalus confertiflorus on clays overlying mineralized sandstone that occurs at an average depth of 138 feet is apparently coincidental; the species is not a useful guide in selecting sites for drill holes.

Sulfur or gypsum indicator plants are effective indicators only where the ore occurs at shallow depths. The common wild onion, Allium, and deserttrumpet, Eriogonum inflatum, were studied in connection with the drilling in Pittsburg Park and in the faulted Memphis Hill block. The abundance of these two plants was noted during drilling and was used as a guide in selecting several drill sites. The depth-toore figures given for Eriogonum are misleading because the plants were growing along the rim outcrop of the ore-bearing sandstone and not on the mesa surface above the ore. Ore was found under onion patches in Pittsburg Park at depths of from 2 to 25 feet in a basin where soluble uranium, selenium, and presumably sulfur salts have migrated upward into the surface soils. The Little Eva mine in Pittsburg Park was discovered in an area of indicator plants by a prospector who, using an ultraviolet lamp, followed an increase in 
schroekingerite content downward by digging. Shallow-rooted gypsum plants may thus be useful indicators in area where there has been a particularly strong upward movement of soluble salts.

ASSOCIATION OF INDICATOR PLANTS WITH GEOLOGICALLY FAVORABLE GROUND

The indicator plants are generally restricted to geologically favorable or semifavorable ground and rarely occur on geologically unfavorable ground (table 34). The scarcity of plants on unfavorable ground

TABLE 34.-Association of indicator plants with geologic favorability for ore in the Yellow Cat area

[Figures in parentheses indicate the distribution that would be expected if no relations of plants to or were to exist; computed from proportional distribution of totals]

\begin{tabular}{|c|c|c|c|}
\hline & \multicolumn{3}{|c|}{ Number of drill holes } \\
\hline & $\begin{array}{l}\text { Semitavorable and } \\
\text { favorable ground }\end{array}$ & $\begin{array}{l}\text { Unfavorable } \\
\text { ground }\end{array}$ & $\begin{array}{l}\text { Total } \\
\text { holes }\end{array}$ \\
\hline $\begin{array}{l}\text { Indicator plants present } \\
\text { Indicator plants absent }\end{array}$ & $\begin{array}{ll}311 & (206) \\
497 & (602)\end{array}$ & $\begin{array}{r}12(117) \\
448(343)\end{array}$ & $\begin{array}{l}323 \\
945\end{array}$ \\
\hline Total drill holes_... & 808 & 460 & 1,268 \\
\hline
\end{tabular}

can be a major guide in reducing moderate or closely spaced drilling in the Thompson district. Of the holes drilled in areas supporting the growth of proven indicator plants, 97 percent were found to be in geologically favorable or semifavorable ground, and only 3 percent in unfavorable ground. The distribution of plants around drill holes in favorable ground is a further useful guide in drilling, as the favorable areas are large and the amount of mineralized ground within these areas is moderately small. The number of mineralized holes and ore holes drilled in semifavorable and favorable ground is almost exactly the same as the number of holes around which indicator plants occur.

\section{ASSOCIATION OF INDICATOR PLANTS WITH MINERALIZED GROUND AND WITH ORE}

Indicator plants were noted near 63 percent of the ore holes, 46 percent of the mineralized holes, and only 12 percent of the unmineralized holes drilled in the area mapped. (See table 35.) Note from the table that three times as many plants are associated with ore holes as would be expected from random occurrence. This distribution is shown graphically in figure 13 , in which a proportionate part of each bar should be dark if the plants were distributed randomly. 
Out of 81 ore holes drilled in the area of plant mapping, indicator plants occurred at 51 sites. A direct comparison between plant occurrence and drill holes is the logical way of handling the large amount of data statistically, but it does not give a true picture of the number of ore bodies or mineralized localities with which plants are associated

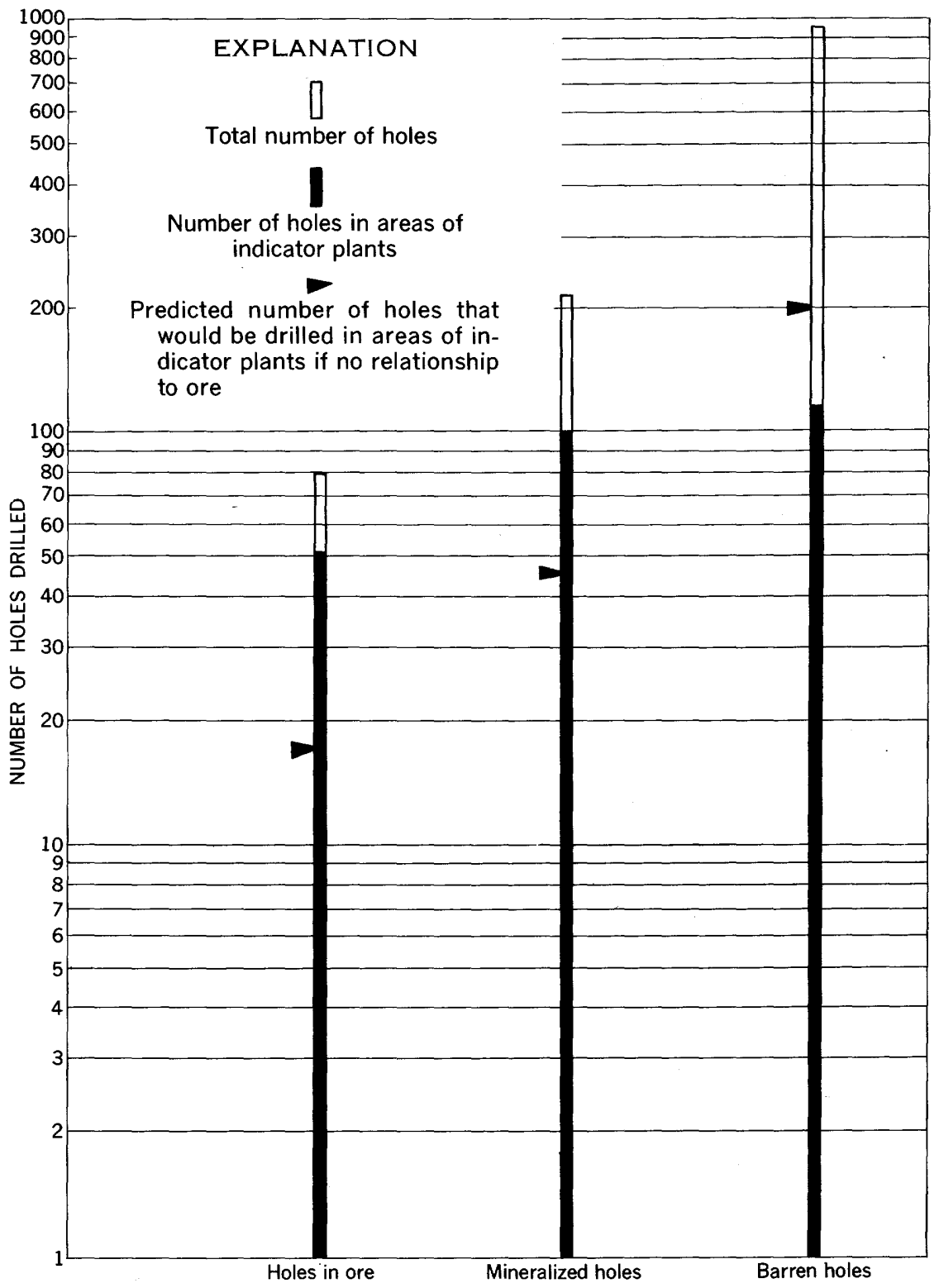

Figure 13.-Bar diagram of indicator-plant distribution compared to holes drilled in Yellow Cat area. 
nor does it take into account the existing mines and prospects. A rough calculation was made from the maps as follows:

Occurrence of indicator plants

\begin{tabular}{c|r|r}
\hline \multicolumn{1}{c|}{ Indicator species } & $\begin{array}{r}\text { At preexisting mines } \\
\text { and prospects }\end{array}$ & $\begin{array}{c}\text { At mineralized } \\
\text { localities discovered } \\
\text { in drilling }\end{array}$ \\
\hline $\begin{array}{c}\text { Astragalus pattersoni } \\
\text { preussi } \\
\text { confertiflorus }\end{array}$ & 35 & 21 \\
No indicator plants & 3 & 15 \\
\hline
\end{tabular}

$\mathrm{T}_{\mathrm{ABLE}}$ 35.-Association of indicator plants with mineralized ground in the Yellow

[Figures in parentheses indicate the expectable distribution if no relation of plants to ore or mineralized ground existed-computed from proportional distribution of totals]

\begin{tabular}{|c|c|c|c|c|}
\hline & \multicolumn{4}{|c|}{ Number of drill holes } \\
\hline & $\begin{array}{l}\text { Ore-bearing } \\
\text { ground } 1\end{array}$ & $\underset{\text { ground 2 }}{\text { Mineralized }}$ & $\underset{\text { ground }}{\text { Unmineralized }}$ & Total \\
\hline $\begin{array}{l}\text { Indicator plants present }{ }^{3} \\
\text { Indicator plants absent }\end{array}$ & $\begin{array}{l}51(17) \\
30(64)\end{array}$ & $\begin{array}{c}99(46) \\
117(170)\end{array}$ & $\begin{array}{l}113(200) \\
838(751)\end{array}$ & $\begin{array}{l}263 \\
985\end{array}$ \\
\hline Total holes drilled . - & 81 & 216 & 951 & 1,248 \\
\hline $\begin{array}{l}\text { Ratio of botanically favorable } \\
\text { holes to total drill holes of each } \\
\text { type (in percent) }\end{array}$ & 63 & 46 & 12 & \\
\hline
\end{tabular}

${ }_{1}^{1}$ Determined by chemical analysis to be more than 0.1 percent $\mathrm{U}_{3} \mathrm{O}_{8}$ or 1.0 percent $\mathrm{V}_{2} \mathrm{O}_{5}$.

2 Visual estimate or gamma-ray determination of mineral content; more than 0.02 percent $\mathrm{U}_{3} \mathrm{O}_{8}$ or 0.1 percent $\mathrm{V}_{2} \mathrm{O}_{3}$, and less than ore grade.

3 Corrected to exclude holes drilled on plant patches growing on stream alluvium.

Five ore bodies were found by use of plant data only. These ore bodies include two small high-grade mineralized logs at a depth of about 5 feet on Yollow Cat Mesa and three ore bodies, each containing several thousand tons of ore, that were drilled in areas of Astragalus pattersoni in Pittsburg Park and west of the Yellow Cat Campsite on the Parko 23 claims. An extension of known ore at the Little Pittsburg mine was clearly outlined by Astragalus. Two small ore bodies and the Little Eva deposit were discovered by private individuals in areas where plants had been mapped as part of the present study.

\section{THE DEPTH FACTOR}

The effectiveness of indicator plants in outlining ore is, of course, limited by depth to ore. When plant distribution around mineralized holes and around ore holes is studied in regard to depths (as shown in table 36 ), it is evident that at least some indicator plants are asso- 
TABLE 36.-Comparison of indicator-plant distribution with drilling results at various depths

\begin{tabular}{|c|c|c|c|c|c|c|c|c|c|c|}
\hline \multirow[b]{2}{*}{ Depth drilled (feet) } & \multirow[b]{2}{*}{$\begin{array}{c}\text { Number } \\
\text { holes } \\
\text { drilled }\end{array}$} & \multicolumn{3}{|c|}{ Mineralized holes } & \multicolumn{3}{|c|}{ Ore holes } & \multicolumn{3}{|c|}{ Mineralized holes and ore holes } \\
\hline & & $\begin{array}{c}\text { Number of } \\
\text { holes in which } \\
\text { plants are } \\
\text { present }\end{array}$ & $\begin{array}{c}\text { Number of } \\
\text { holes in which } \\
\text { plants are not } \\
\text { present }\end{array}$ & $\begin{array}{c}\text { Percent of } \\
\text { holes in which } \\
\text { plants are } \\
\text { present }\end{array}$ & $\begin{array}{c}\text { Number of } \\
\text { holes in which } \\
\text { plants are } \\
\text { present }\end{array}$ & $\begin{array}{c}\text { Number of } \\
\text { holes in which } \\
\text { plants are not } \\
\text { present }\end{array}$ & $\begin{array}{c}\text { Percent of } \\
\text { holes in which } \\
\text { plants are } \\
\text { present }\end{array}$ & $\begin{array}{c}\text { Number of } \\
\text { holes in which } \\
\text { plants are } \\
\text { present }\end{array}$ & $\begin{array}{c}\text { Number of } \\
\text { holes in which } \\
\text { plants are not } \\
\text { present }\end{array}$ & $\begin{array}{c}\text { Percent of } \\
\text { holes in which } \\
\text { plants are } \\
\text { present }\end{array}$ \\
\hline $\begin{array}{l}0-9 \\
10-20 \\
21-32 \\
33-49 \\
50-67 \\
68-99 \\
100-115 \\
116-150 \\
151-169 \\
170+\end{array}$ & $\begin{array}{l}16 \\
35 \\
33 \\
32 \\
33 \\
34 \\
36 \\
35 \\
31 \\
12\end{array}$ & $\begin{array}{r}6 \\
23 \\
18 \\
11 \\
10 \\
11 \\
4 \\
7 \\
7 \\
2\end{array}$ & $\begin{array}{r}5 \\
6 \\
6 \\
16 \\
16 \\
14 \\
18 \\
17 \\
12 \\
7\end{array}$ & $\begin{array}{l}54 \\
78 \\
75 \\
41 \\
38 \\
44 \\
28 \\
29 \\
36 \\
22\end{array}$ & $\begin{array}{r}3 \\
2 \\
9 \\
4 \\
4 \\
4 \\
11 \\
9 \\
5 \\
0\end{array}$ & $\begin{array}{l}2 \\
4 \\
0 \\
1 \\
3 \\
5 \\
3 \\
2 \\
7 \\
3\end{array}$ & $\begin{array}{r}60 \\
33 \\
100 \\
60 \\
56 \\
44 \\
78 \\
81 \\
41 \\
0\end{array}$ & $\begin{array}{r}9 \\
25 \\
27 \\
15 \\
14 \\
15 \\
15 \\
16 \\
12 \\
2\end{array}$ & $\begin{array}{r}7 \\
10 \\
6 \\
17 \\
19 \\
19 \\
21 \\
19 \\
19 \\
10\end{array}$ & $\begin{array}{l}54 \\
70 \\
81 \\
46 \\
42 \\
43 \\
42 \\
45 \\
38 \\
16\end{array}$ \\
\hline Summary ....- & 297 & 99 & 117 & 46 & 51 & 30 & 62 & 150 & 147 & 50 \\
\hline \multicolumn{8}{|c|}{ Barren holes (total number drilled, 971) } & 133 & 838 & 14 \\
\hline \multicolumn{8}{|c|}{$\begin{array}{l}\text { Summary, excluding holes drilled on plant patches growing in alluvium along major } \\
\text { stream. }\end{array}$} & 113 & 838 & 12 \\
\hline
\end{tabular}


ciated with ores at depths much greater than was previously believed possible. Astragalus pattersoni and A. preussi, on which most of these statistics are based, are most effective in indicating mineralized sandstone and ore sandstone that occur at a depth of 10-32 feet. The percentage of effectiveness is fairly constant for depths of 32-170 feet. Plants in the Yellow Cat area could be used to locate 43 percent of the mineralized ground to a depth of 170 feet but are not effective in indicating ore deposits at greater depths.

\section{PLant-analysis method}

To test the plant-analysis method about 400 samples of trees and shrubs were collected by pattern or traverse sampling and were analyzed for uranium content by the fluorimetric method in the Denver laboratory. (The limit of sensitivity of this method is 0.3 ppm uranium in the ash.) Of these samples, 59 contained 1-2 ppm uranium and 52 contained more than $2 \mathrm{ppm}$. Unfortunately, the areas were not intensively drilled, and 9 ore holes and 10 mineralized holes were inadvertently drilled near trees having anomalous uranium contents. The values for plants and drill holes can be compared on the map (pl. 3 ).

Several areas of favorable ground were suggested by the values obtained on Yellow Cat Mesa, the McCoy group, and the Flattop area. Nearly all mineralized holes drilled on Yellow Cat Mesa (shown in pl. 3) were in ground that was considered to be botanically favorable. Two shallow ore bodies were discovered by drilling based on the information obtained from study of uranium contents in shadscale. One of thiese was a highly mineralized log that occurred only 15 feet from a known ore body; no additional ore bodies were discovered in the McCoy group or Flattop claims. All analytical information has been compiled in table 37 .

The areas of anomalous uranium values were not sufficiently tested by drilling to permit a definitive appraisal of the plant-analysis method. The results of this appraisal suggest that the cutoff uranium values between barren and mineralized ground, as indicated by analysis of the ash of juniper and of shadscale saltbush, are virtually the same and that the two plants can be used interchangeably in areas of shallow deposits. The roots of shadscale saltbush are shallow, however, and do not, like the juniper, reach the perched water tables that commonly occur within the ore zone. The ore bodies that occur in the McCoy bench range in depth from 3 feet at the west end to 40 feet near the McCoy cabin. Both juniper and shadscale saltbush contained anomalous amounts of uranium at places where the ore was at a depth of not more than 20 feet; where the ore lay at greater depths, the deep-rooted juniper continued to be an effective sampling 


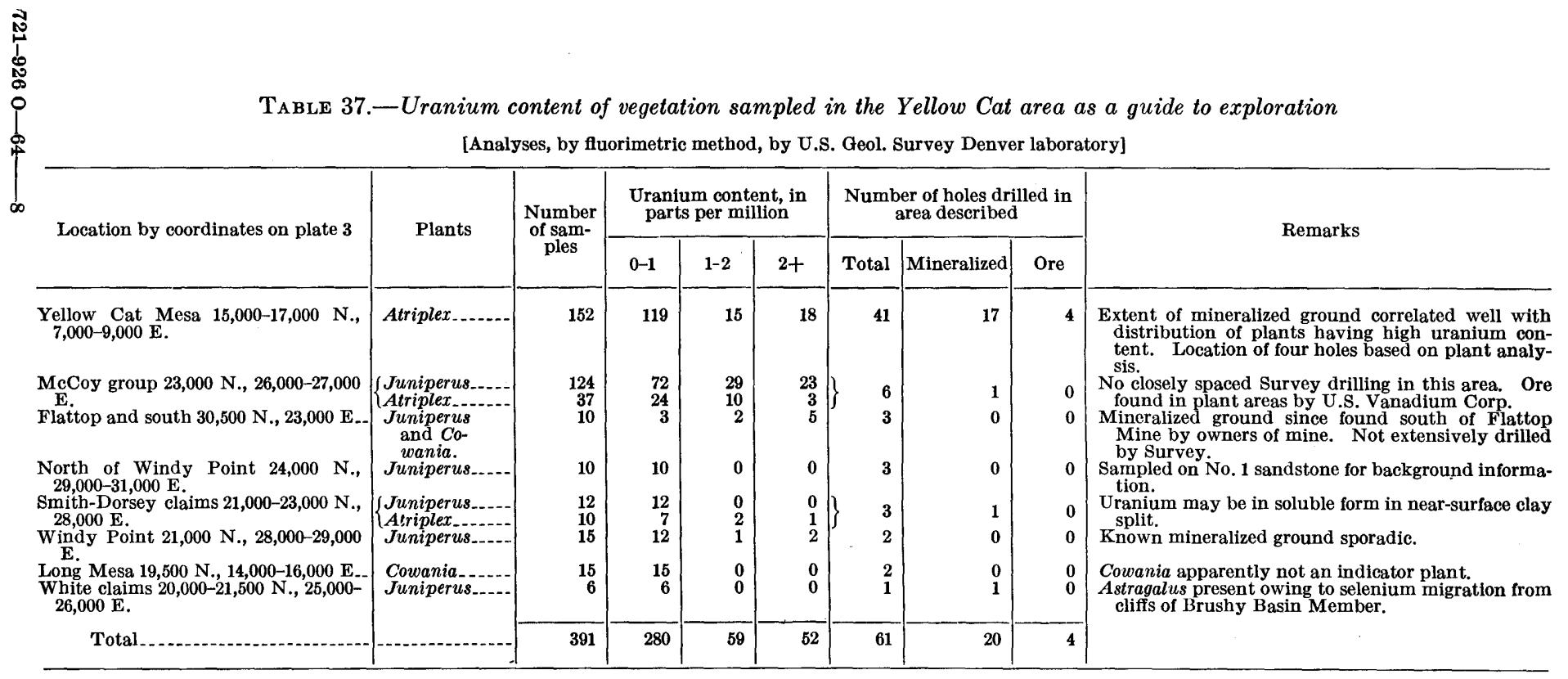


medium, but the shallow-rooted shadscale saltbush did not indicate any mineralization.

\section{FURTHER LIMITATIONS OF BOTANICAL PROSPECTING METHODS}

The effectiveness of either plant method as a guide to uranium deposits is dependent mainly on the depth to mineralized ground and on the availability of uranium and selenium to the plant roots. The species of plants vary in their root habits; in their tolerance to large amounts of sulfates, selenates, and radioactive materials in the soil; and in their capacity to absorb elements concentrated in the ore bodies. Basically, the abundance of these elements in soil and water near an ore body is controlled by the chemical and physical characteristics of the host rock and by the influence of structure and topography on their solution and transportation. In addition, much depends on whether the elements in question are only at ground-water level, are in the capillary fringe above the ground-water table, or have migrated to the surface soil along fractures or through permeable beds. All these variables must be considered in any interpretation of the distribution patterns of indicator plants and of the significance of anomalous contents in prospecting for ore deposits.

Before botanical maps can be profitably used in selecting drilling sites, the sedimentary features, direction of ground-water movement, joint or fracture patterns, folding, and other topographic and geologic features must be studied carefully. This prerequisite is illustrated by a series of holes drilled in Pittsburg Park on the basis of Astragalus pattersoni distribution. The plants were growing in two straight parallel lines on what appeared to be shifting dune sand. Three holes were drilled on each line of plants but none penetrated ore. A seventh hole midway between the lines penetrated an ore body at a depth of 26 feet. The ore body is now known to be 80 feet long and to lie directly between the lines of plants. Selenium apparently has migrated out from the ore body and up along two vertical fractures. Many holes have probably been incorrectly placed because plant data were tested without regard to the topography, dip of strata, and direction of migration of the water-soluble selenium. These geologic factors could not be considered in the statistical study of the results of drilling conducted on the basis of botanical anomalies, and no holes have been eliminated from this study because of incorrect interpretation of plant data. Obviously the effectiveness and value of botanical prospecting would be strengthened by a careful geologic analysis of indicator-plant distribution before and during exploration. 


\section{SUMMARY}

Oxidized ore bodies and surrounding sandstone in the Yellow Cat area of the Thompson district were studied to learn what accessory elements are concentrated with uranium and vanadium in the ore deposits; to discover how the geochemical behavior of these elements is affected by weathering; and to decide whether selenium, molybdenum, or some other metal can be used as a pathfinder element in prospecting for uranium-vanadium deposits. The contents of sulfur, selenium, arsenic, and molybdenum are more than 10 times greater in the uranium-vanadium ore bodies than in the enclosing sandstone, and these elements are assumedly an intrinsic part of the ore. 'The same elements are also much more abundant in the sandstone surrounding the ore bodies than Newman (1957) and Shoemaker and others (1959) found them to be in country rock more distant from ore; each ore body in the sandstone, then, is enveloped by a geochemical halo of selenium, molybdenum, arsenic, and sulfur.

The mudstone layers that separate the four ore-bearing sandstone beds of the Salt Wash Member and the interstitial clay within the sandstone are montmorillonitic and seem to contain less of the accessory elements and ore elements near the sandstone ore bodies than in barren parts of the section at some distance from the ore. The uranium was possibly derived from alteration of clays that originated as volcanic ash, and it has since precipitated in the nearest sandstone bed.

Special studies were made of an open pit where ore occurs at a depth of 44 feet. Selenium and molybdenum are concentrated to a greater degree in the partially mineralized sandstone just above the ore than in the ore itself, and anomalous contents of uranium, arsenic, and vanadium are found in the sandstone and mudstone for varying distances above the ore. All these elements, therefore, are potentially useful in prospecting by plant analysis.

Three springs that were tested in the area contained from 0.2 to 0.7 ppm uranium and 1 to $3 \mathrm{ppm}$ selenium. Although these contents are very high, water sampling was not considered as a prospecting method because water is scarce in the area, and because the three springs issue from known mines. A well-developed residual soil is lacking in the arid Yellow Cat area, and for this reason only colluvium was tested as a means of soil prospecting. One hundred and fifty samples were collected and analyzed. The average content of unmineralized colluvium was $0.5 \mathrm{ppm}$ uranium; the content of colluvium below a sandstone outcrop that has since been shown to be mineralized ranged from 12 to $47 \mathrm{ppm}$ uranium. The vanadium content of the colluvium can also be used in prospecting. 
Because surface waters and residual soil cover are lacking in the Yellow Cat area, its vegetation was investigated with special thoroughness as a prospecting medium. All species of plants rooted in mineralized ground contain concentrations of uranium, vanadium, selenium, and molybdenum. The ratio of uranium in plants growing on mineralized ground to that in plants growing on barren ground is larger than for any other element. As the uranium content in the leaves and end branches of trees and deep-rooted perennial shrubs was found to correlate well with that of the rocks in which the plants were rooted, 400 samples of juniper and deep-rooted shrubs were collected and analyzed fluorimetrically for uranium. On barren ground the uranium content is generally about $0.5 \mathrm{ppm}$, whereas on mineralized ground it is commonly greater than $2 \mathrm{ppm}$. Ore has since been mined from areas outlined by analysis of both juniper and shadscale saltbush.

Near the uranium deposits, unusually large concentrations of particular metals, increased radioactivity, and a local change in $\mathrm{pH}$ make the environment favorable for the growth of certain indicator plants. Gardon-plot experiments showed that selenium, sulfur, calcium, and phosphorus are more available to plants in a carnotite environment and that uranium and vanadium are more available in the presence of sulfur and selenium. The distribution of six indicator species was mapped throughout the area. Astragalus pattersoni, a white-flowered loco weed, and $A$. preussi, a purple-flowered species, were accumulators not only of selenium, as had long been known, but of uranium, vanadium, and molybdenum as well, and their distribution correlates more consistently with mineralized ground than that of any of the other plants. Later, 1,268 holes were drilled for the U.S. Geological Survey in the area mapped, and geologically favorable ground was outlined.

A comparison of the indicator-plant data with drilling results in the Yellow Cat area shows that the presence of indicator plants nearly always denotes proximity of geologically favorable ground. Plant mapping indicated 81 percent of the mineralized ground less than 32 feet below the surface and 42 percent of the mineralized ground lying at depths between 32 and 170 feet. For mineralized ground at depths exceeding 170 feet, the ratio indicated by plant mapping dropped abruptly to 16 percent or about the same as on barren ground. Several ore bodies were found by means of plants in areas which, from geologic evidence, were believed unfavorable for finding ore. 


\section{SELECTED BIBLIOGRAPHY}

Acqua, C., 1912, The action of uranium on the vegetable cell: Arch. farmacol. sper., v. 14 , no. 2 , p. $81-84$.

- 1913, Nuclear degeneration produced by uranium in the plant cell: R. accad. Lincei e. Sci., Rendus, v. 22, p. 390-392 (in Italian).

Agarwala, S. C., and Hewitt, E. J., 1954, Molybdenum as a plant nutrient: Jour. Horticulture Sci., v. 29, p. 278-290.

Anderson, M. S., Lakin, H. W., Beeson, K. C., Smith, F. F., and Thacker, Edward, 1961, Selenium in agriculture: U.S. Dept. Agriculture Handbook $200,65 \mathrm{p}$.

Anderson, R. Y., and Kurtz, E. B., Jr., 1955, Biogeochemical reconnaissance of the Annie Laurie uranium prospect, Santa Cruz County, Arizona: Econ. Geology, v. 50, no. 2, p. 227--232.

1956, A method for the determination of alpha-radioactivity in plants as a tool for uranium propsecting: Econ. Geology, v. 51, no. 1, p. 64-68.

Bambacioni-Mezzetti, V., 1934, Action of uranium chloride and of gamma-rays on the geotropical sensibility of roots: Soc. Italiana progresso sci. Atti., v. 22 , no. 3 , p. $56-57$.

Baranov, V. V., 1939, Assimilation of radioactive elements by plants: Acad. sci., Comptes rendus, U.R.S.S., v. 24, p. 951-954.

- 1957, Halos of molybdenum dissemination in one of the sections of the Tyrny-Ausy deposit: Geokhimiya, no. 2, p. 125-132 (in Russian).

Barshad, Isaac, 1948, Molybdenum content of pasture plants in relation to toxity to cattle: Soil Sci., v. 66, no. 3, p. 187-195.

___ 1951, Factors affecting the molybdenum content of pasture plants. I. Nature of soil molybdenum, growth of plants, and soil $\mathrm{pH}$ : Soil Sci., v. 71, p. 297-313.

Beath, O. A., 1937, The occurrence of selenium and seleniferous vegetation in Wyoming, II. Seleniferous vegetation: Wyoming Univ. Agr. Expt. Sta. Bull. 221, p. 29-64.

- 1943, Toxic vegetation growing on the Salt Wash sandstone member of the Morrison formation: Am. Jour. Botany, v. 30, no. 9, p. 698-707.

Beath, O. A., Draize, J. H., Eppson, H. F., Gilbert, C. S., and McCreary, O. C., 1934, Certain poisonous plants of Wyoming activated by selenium and their associates with respect to soil types: Am. Pharmaceutical Assoc. Jour., v. 23, p. 94-97.

Beath, O. A., and Eppson, H. F., 1947, The form of selenium in some vegetation: Wyoming Univ. Agr. Expt. Sta. Bull. 278, 15 p.

Beath, O. A., Eppson, H. F., and Gilbert, C. S., 1935, Selenium and other toxic materials in soils and vegetation: Wyoming Univ. Agr. Expt. Sta. Bull. $206,55 \mathrm{p}$.

Beath, O. A., Gilbert, C. S., and Eppson, H. F., 1937a, Selenium distribution in and seasonal variation of type vegetation occurring on seleniferous soils: Am. Pharmaceutical Assoc. Jour., v. 26, p. 394-405.

$-1937 \mathrm{~b}$, Selenium in soils and vegetation associated with rocks of Permian and Triassic age: Am. Jour. Botany, v. 24, no. 2, p. 96-101.

- 1939, The use of indicator plants in locating seleniferous areas in western United States: Am. Jour. Botany, Pt. 1, General, v. 26, no. 4, p. 257-269 (1939) ; Pt. 2, Correlations studies by States, v. 26, no. 5, p. 296-315 (1939). 1940, The use of indicator plants in locating seleniferous areas in western United States: Am. Jour. Botany, Pt. 3, Further studies, v. 27, p. 564-573 (1940). 
Beath, O. A., Gilbert, C. S. and Eppson, H. F., 1941, The use of indicator plants in locating seleniferous areas in western United States: Am. Jour. Botany, Pt. 4, Progress report, v. 28, p. 887-900 (1941).

Beath, O. A., Hagner, A. F., and Gilbert, C. S., 1946, Some rocks and soils of high selenium content: Wyoming Geol. Survey Bull. 36, 23 p.

Becquerel, M. Paul, and Rousseau, Jacqueline, 1947, Effect of growth substances and either uranium nitrate or manganese sulfate on germination and productivity of Pisum sativum; Acad. sci. [Paris] Comptes rendus, v. 224, p. 773-775.

Bell, K. G., and Rogers, A. S., 1950, Experimental gamma-ray logging of drill holes in the Calamity area, Mesa County, Colorado: U.S. Geol. Survey TEI-84, issued by U.S. Atomic Energy Comm. Tech. Inf. Service, Oak Ridge, Tenn.

Bertrand, Didier, 1939, Ưber die Vertreitung des Molybdäns bei den Pflanzen [On the distribution of molybdenum in plants]: Acad. sci. [Paris] Comptes rendus, v. 208, p. 2024-2026.

- 1940a, La diffusion du molybdène chez les végétaux [Distribution of molybdenum in plants]: Soc. Chim. Biol. Bull., v. 22, p. 60-66.

- 1940b, Contribution a l'etude de la diffusion du molybdène chez les vegetaux [Contribution to a study of the distribution of molybdènum in plants]: Ann. Inst. Pasteur, v. 64 (1), p. 90-96.

- 1941, Vanadium in plants: Soc. Chim. Biol. Bull., v. 23, p. 391-397. 1942a, Dosage du vanadium chez les végétaux [Content of vanadium in plants]: Soc. Chim. Paris Bull., v. 9, ser. 5, p. 121-124, 128-135.

$1942 \mathrm{~b}$, Recherches sur le vanadium chez les végétaux [Research on vanadium in plants]: Ann. Inst. Pasteur, v. 68, p. 58-68.

- 1950, The biogeochemistry of vanadium (Translated by Vera Lee), in Survey of contemporary knowledge of biogeochemistry: Am. Mus. Nat. History Bull., v. 94, art. 7, p. 409-455.

Bevilotti, V., 1945, Biological action of radioactive substances, VI. Action of uranium on the germination of vegetable seeds: Soc. Italiana Biol. Sper. Bull., v. 20, p. 558-559.

Blume, J. M., Hagen, C. E., and Mackie, R. W., 1950, Radiation injury to plants grown in nutrient solutions containing $\mathrm{P}^{32}$ : Soil Sci., v. 70, p. 415-426.

Bortels, Hermann, 1936, Weitere Untersuchungen über die Bedeutung von Mo, V, W, und anderen Erdaschenstoffen für die stickstoffbindende und andere Mikroorganischenen [Further studies on the significance of molybdenum, vanadium, tungsten, and other soil materials on nitrogen-fixing and other microorganisms]: Zentr. Bakt. Parasitenk. Div. 2, v. 95, p. 193-217.

_ 1937, Utber die Wirkung von Mo und V auf Leguminosae [The effect of molybdenum and vanadium compounds on Leguminosae]: Archeol. Mikrobiol., v. 8, p. 13-26.

Botinelly, Theodore, and Fischer, R. P., 1959, Mineralogy and geology of the Rifle and Garfield mines, Garfield County, Colorado, in Geochemistry and mineralogy of the Colorado Plateau uranium ores: U.S. Geol. Survey Prof. Paper 320, p. 213-218.

Britton, J. W., and Goss, H., 1946, Chronic molybdenum poisoning in cattle: Am. Veterinary Med. Assoc. Jour., v. 108, p. 176-178.

Burk, Dean, and Horner, C. K., 1935, The specific catalytic role of molybdenum and vanadium in nitrogen fixation and amide utilization by Azotobacter: Internat. Soil Sci. Cong., 3d, Oxford, England, 1935, Trans., v. 1, p. 152-155. 
Byers, H. G., 1934, Selenium, vanadium, chromium, and arsenic in one soil: Indus. Eng. Chemistry (News Ed.), v. 12, p. 122.

1935, Selenium occurrence in certain soils in the United States, with a discussion of related topics, I: U.S. Dept. Agriculture Tech. Bull. 482, 47 p.

- 1936, Selenium occurrences in certain soils in the United States, with a discussion of related topics, II: U.S. Dept. Agriculture Tech. Bull. 530, 78 p.

1937, Selenium in Mexico: Indus. Eng. Chemistry, v. 29, p. 1200-1202.

Byers, H. G., and Knight, H. G., 1935, Selenium in soils: Indus. Eng. Chemistry, v. 27, p. 902-904.

Byers, H. G., Miller, J. T., Williams, K. T., and Lakin, H. W., 1938, Selenium occurrence in certain soils in the United States, with a discussion of related topics, III: U.S. Dept. Agriculture Tech. Bull. 601, 74 p.

Byers, H. G., Williams, K. T., and Lakin, H. W., 1936, Selenium in Hawaii and its probable source in the United States: Indus. Eng. Chemistry, v. 28, p. 821-823.

Cadigan, R. A., 1959, Characteristics of the host rock, in Geochemistry and mineralogy of the Colorado Plateau uranium ores: U.S. Geol. Survey Prof. Paper 320, p. 13-24.

Cameron, C. A., 1880, Preliminary note on the absorption of selenium by plants: Royal Dublin Soc. Sci. Proc., v. 2, p. 231-233.

Cannon, Helen L., 1952, The effect of uranium-vanadium deposits on the vegetation of the Colorado Plateau: Am. Jour. Sci., v. 250, no. 10, p. 735-770.

Carlisle, Donald, and Cleveland, G. B., 1958, Plants as a guide to mineralization: California Div. Mines Spec. Rept. 50, $31 \mathrm{p}$.

Clarke, F. W., 1924, The data of geochemistry: U.S. Geol. Survey Bull. 770, $841 \mathrm{p}$.

Coleman, R. G., 1956, The occurrence of selenium in sulfides from sedimentary rocks of the western United States [abs.]: Econ. Geology, v. 51, no. 1, p. 112.

Coleman, R. G., and Delevaux, Maryse, 1957, Occurrence of selenium in sulfides from some sedimentary rocks of the western United States: Econ. Geology, v. 52 , no. 5 , p. $499-527$.

Crafts, A. S., Currier, H. B., and Stocking, C. R., 1949, Water in the physiology of plants: Waltham, Mass., Chronica Botanica Co., 261 p.

Cripps, G. S., 1955, Where are the areas of molybdenum deficiency?: Chemurgic Digest, v. 14, no. 10.

Dane, C. H., 1935, Geology of the Salt Valley anticline and adjacent areas, Grand County, Utah: U.S. Geol. Survey Bull. 863, 184 p.

Debnam, A. H., 1954, Biogeochemical prospecting investigations in the northern territory (Australia); Australia Dept. Natl. Devel., Bur. Mineral Resources, Geology, and Geophysics.

Demarcay, Eugene, 1900, Sur la présence dans les végétaux du vanadium, du molybdène, et du Crome [Vanadium, molybdenum, and crhromium in plants]: Acad. Sci. [Paris] Comptes rendus, v. 130, no. 2, p. 91, 92.

Denson, N. M., Zeller, H. D., Stephens, J. G., 1955, Water sampling as a guide in the search for uranium deposits and its use in evaluating widespread volcanic units as potential source beds for uranium, in Page, Stocking, and Smith, p. 673-680.

Dingwall, Andrew, McKibbon, R. R., and Beans, H. T., 1934, Studies on the distribution of molybdenum in biological material, I. A spectrographic study of the occurrence of Mo in plants grown in the Province of Quebec: Canadian Jour. Research, v. 11, p. 32-39.

Ditmars, R. L., 1931, Reptiles of the world: New York, .Macmillan Co., 409 p. 
Drobkov, A. A., 1937, The influence of the radioactive elements uranium, radium, thorium, and actinium on the yield of plants: Acad. sci. Conptes rendus, SSSR, v. 17, p. 229-232.

- 1940, The influence of radioactive elements on the yield of plants: Acad. sci. URSS, Bull., Biol. Ser., p. 783-801.

1951, The part played by natural radioactive elements in biological processes: Uspekhi Sovremennoi Biol., v. 31, no. 1, p. 82-100.

Ducloux, E. H., and Cobanera, M. L., 1911-12, The influence of cobalt and vanadium salts on vegetative growth: Rev. Mus. LaPlata, v. 18, p. 145.

Elston, D. P., and Botinelly, Theodore, 1959, Geology and mineralogy of the J. J. Mine, Montrose County, Colorado, in Geochemistry and mineralogy of the Colorado Plateau uranium ores: U.S. Geol. Survey Prof. Paper 320, p. 203-211.

Epstein, Emanuel, 1955, Plant physiology, v. 30, p. 529-535.

1956, Passive passage and active transport of ions in plant roots, in A Conference on radioactive isotopes in agriculture: U.S. Atomic Energy Comm. TID 7512, p. 297-301.

Evans, H. J., Purvis, E. R., and Bear, F. E., 1951, Effect of soil reaction on availability of molybdenum: Soil Sci., v. 71 , no. 2 , p. 117-124.

Favilli, R., 1948, On the action of uranium and some of its compounds on vegetation: Esper. Ric. 3, p. 1-41.

Ferguson, W. S., Lewis, A. H., and Watson, S. J., 1938, Action of molybdenum in nutrition of milking cattle: Nature, v. 141, p. 553.

1940, The teart pastures of Somerset, cause of teartness and its prevention: Jealotts Hill Research Sta. England Bull. 1., 28 p.

1943, The teart pastures of Somerset, I. The cause and cure of teartness: Jour. Agr. Sci., v. 33, p. 44-51.

Fischer, R. P., 1942, Vanadium deposits of Colorado and Utah, a preliminary report: U.S. Geol. Survey Bull. 936-P, p. 363-394.

Fix, P. F., 1954, Uranium in natural waters: U.S. Geol. Survey TEM-783, issued by Atomic Energy Comm. Tech. Inf. Service, Oak Ridge, Tenn.

1955, Hydrogeochemical exploration for uranium, in Page, Stocking, and Smith, p. 667-671.

Fletcher, M. H., and Warner, E. R., 1953, A fluorimeter for solutions: U.S. Geol. Survey Circ. 311,9 p.

Foster, M. D., 1959, Chemical study of the mineralized clays, in Geochemistry and mineralogy of the Colorado Plateau uranium ores: U.S. Geol. Survey Prof. Paper 320, p. 121-132.

Franke, K. W., 1934, A new toxicant occurring naturally in certain samples of plant foodstuffs, I. Results obtained in preliminary feeding trials: Jour. Nutrition, v. 8, p. 597-608.

Franke, K. W., Rice, T. D., Johnson, A. G., and Schoening, H. W., 1934, Preliminary field survey of the so-called "alkali disease" of livestock: U.S. Dept. Agriculture Circ. 320. 9 p.

Free, E. E., and Trelease, S. F., 1917, The effect of certain mineral poisons on young wheat plants in three-salt nutrient solutions: Johns Hopkins Univ. Circ. 293, p. 199-201.

Gager, C. S., 1907, Some effects of radioactivity on plants: Science, v. 25, no. 663,

p. 264.
1908, Effects of the rays of radium on plants: New York Bot. Garden Mem., v. 4, 278 p. 
Garrels, R. M., 1957, Volcanic glasses as a possible source of uranium, in Geologic investigations of radioactive deposits, semiannual progress report, December 1, 1956, to May 31, 1957: U.S. Geol. Survey TEI-690, p. 554-555, issued by U.S. Atomic Energy Comm. Tech. Inf. Service, Oak Ridge, Tenn.

Garrels, R. M., and Christ, C. L., 1959, Behavior of uranium minerals during oxidation, in Geochemistry and mineralogy of Colorado Plateau uranium ores: U.S. Geol. Survey Prof. Paper 320, p. 81-89.

Garrels, R. M., and Larsen, E. S., 3d, 1959, The known and unknown, in Geochemistry and mineralogy of the Colorado Plateau uranium ores: U.S. Geol. Survey Prof. Paper 320, p. 231-326.

Gericke, S., 1941, Weitere Versuche über die Wirkung des Spurenelements Vanadin auf das Pflanzenwachstum: Bodenkunde u. Pflanzenernähr., v. 23, p. 342350.

Gericke, S., and Rennenkampff, E. Von, 1940a, Die Wirkung das Spurenelements Vanadin auf das Pflanzen wachstum [The effect of the trace element vanadium on plant growth]: Prakt. Blätter Pflanzenbau u. Pflanzenschutz, v. 17, p. 17-22 (1939).

- 1940b, Untersuchungen über die Wirkung des V auf des Pflanzenwachstum [The effect of $\mathrm{V}$ on plant growth]: Bodenkunde $\mathrm{u}$. Pflanzenernähr., v. 18, p. 305-315.

Ginzberg, I. I., 1957, Experimental development and theoretical basis of geochemical methods of prospecting for ore, non-ferrous and rare metals: USSR, Govt. Sci. and Tech. Pub. House, Literature on geology and conservation of natural resources. Translation by V. P. Sokoloff.

Gleditsch, E., and Graf, T., 1942, Some effects of radioactive materials on plant growth: Nord. Jordbrugsforskn, v. 24, p. 225-236.

Goldschmidt, V. M., 1954, Geochemistry: Oxford, England, Clarendon Press, $730 \mathrm{p}$.

Grimaldi, F. S., May, Irving, and Fletcher, M. H., 1952, U.S. Geological Survey fluorometric methods of uranium analysis: U.S. Geol. Survey Circ. 199, 20 p.

Grimaldi, F. S., May, Irving, Fletcher, M. H., and Titcomb, Jane, 1954, Collected papers on methods of analysis for uranium and thorium: U.S. Geol. Survey Bull. 1006, 184 p.

Gunckel, J. E., 1956, Morphological effects of ionizing radiation in plants: Am. Inst. Biol. Sci., reprint of address Aug. 29, Storrs, Conn.

Haas, A. R. C., and Brusca, J. N., 1953, Molybdenum-deficiency symptoms in lemon and grapefruit leaves: Citrus Leaves, v. 33, no. 8, p. 6-9.

Haertl, E. J., and Martell, A. E., 1956, Metal chelates in plant and animal nutrition: Agr. and Food Chemistry Jour., v. 4, no. 1, p. 26-32.

Hance, F. E., 1938, Selenium: Hawaiian Planters' Record, v. 42, p. 197-210.

Harrington, H. D., 1954, Manual of the plants of Colorado: Denver, Colo., Sage Books, $666 \mathrm{p}$.

Hawkes, H. E., 1950, Geochemical prospecting for ores, in Trask, P. E., ed., Applied sedimentation-a symposium: New York, John Wiley \& Sons, $415 \mathrm{p}$.

1957, Principles of geochemical prospecting: U.S. Geol. Survey Bull. 1000-F, p. 225-355.

Hoffman, Josef, 1942, Detection of uranium in living and dead plants: Bodenkunde u. Pflanzenernähr., v. 26, p. 318-327 (in German).

1943, A further contribution to the distribution of uranium in plant material: Bodenkunde u. Pflanzenernähr., Chem. Zentralbl., v. 32, p. 295306 (in German). 
Holland, H. D., Curtiss, B. R., McGill, G. E., and Petersen, J. A., 1957, The distribution of leachable uranium in core samples adjacent to the Homestake ore body, Big Indian Wash, San Juan County, Utah, pt. 1 of The use of leachable uranium in geochemical prospecting on the Colorado Plateau: Econ. Geology,-. 52, no. 5, p. 546-569.

Holland, H. D., Witter, G. G., Jr., Head, W. B. 3d, Petti, R. W., 1958, The use of leachable uranium in geochemical prospecting on the Colorado Plateau, pt. 2 of The distribution of leachable uranium in surface samples in the vicinity of ore bodies: Econ. Geology, v. 53, no. 2, p. 190-209.

Holt, W. L., and Greaves, J. E., 1941, The occurrence of selenium in Utah forage plants: Soil Sci., v. 51, no. 4, p. 299-306.

Hoogteÿling, P. J., and Sizoo, G. J., 1948, Radioactivity and mineral composition of soil: Physica, v. 14, no. 6, p. 357-366.

Huff, L. C., 1954, Preliminary geochemical studies in the Capitol Reef area, Wayne County, Utah: U.S. Geol. Survey TEM-643, 21 p., issued by U.S. Atomic Energy Comm. Tech. Inf. Service, Oak Ridge, Tenn.

Huffman, Claude, Jr., and Riley, L. B., 1956, Determination of uranium in the ash of plants, and its precision: U.S. Geol. Survey TEI-654, 23 p., issued by U.S. Atomic Energy Comm. Tech. Inf. Service, Oak Ridge, Tenm.

Huleatt, W. P., Hazen, S. W., Jr., and Traver, W. M., Jr., 1946, Exploration of vanadium region of western Colorado and eastern Utah: U.S. Bur. Mines Inv. Rept. 3930, $30 \mathrm{p}$.

Hunt, C. B., 1956, Cenozoic geology of the Colorado Plateau: U.S. Geol. Survey Prof. Paper 279, 99 p.

Hurd-Karrer, A. M., 1934, Selenium injury to wheat plants and its inhibition by sulfur: Jour. Agr. Research, v. 49, no. 4, p. 343-357.

— 1935, Factors affecting the absorption of selenium from soils by plants: Jour. Agr. Research, v. 50, p. 413-417.

1937, Comparative toxicity of selenates and selenites to wheat: Am. Jour. Botany, v. 24, no. 10, p. 720-728.

Jones, L. H. P., 1956, Interaction of molybdenum and iron in soils: Science, v. 123, no. 3208 , p. 1116 .

Jornlin, F. M., 1948, The atomic bomb's effects on plants and soils: Fertilizer Rev., v. 8, p. 7-14.

Kamen, M. D., 1946, Survey of contemporary knowledge of biogeochemistry, I. Isotopic phenomena in biogeochemistry: Am. Mus. Nat. History Bull., v. 87 , art. 2 , p. $105-138$.

Keller, W. D., 1956, Studies of clays in Jurassic rocks, in Geologic investigation, of radioactive deposits-Semiannual progress report, December 1, 1955, to May 31, 1956: U.S. Geol. Survey TEI-620, p. 121-123, issued by U.S. Atomic Energy Comm. Tech. Inf. Service, Oak Ridge, Tenn.

- 1959, Clay minerals in the mudstones of the ore-bearing formations, in Geochemistry and mineralogy of the Colorado Plateau uranium ores: U.S. Geol. Survey Prof. Paper 320, p. 113-119.

Kelsey, H. P., and Dayton, W. A., 1942, Standardized plant names: Harrisburg, Pa., J. H. McFarland Co., 675 p.

Kinser, C. A., 1954, The Model VI transmission fluorimeter for the determination of uranium: U.S. Geol. Survey Circ. $330,9 \mathrm{p}$.

Knight, S. H., and Beath, O. A., 1937, The occurrence of selenium and seleniferous vegetation in Wyoming: Wyoming Agr. Expt. Sta. Bull. 221, p. 3-64.

Kramer, P. J., 1957, Outer space in plants: Science, v. 125, no. 3249, p. 633-635. 
Krioukov, V. A., 1931, The physiological influence of Thomas slag and its impurities vanadium and arsenic on plants: Oudobrénié i Ourojaï, v. 3, no. 7, p. 627-635; abstractin Chim. et Industrie 1932, v. 28, p. 443 [1938].

Krumbein, W. C., and Garrels, R. M., 1952, Origin and classification of chemical sediments in terms of $\mathrm{pH}$ and oxidation-reduction potentials: Jour. Geology, v. 60 , no. 1 , p. $1-34$.

Lakin, H. W., 1948, Selenium occurrence in certain soils in United States, with a discussion of related topics, Seventh report: U.S. Dept. Agriculture Tech. Bull. 950, 36 p.

Lakin, H. W., and Byers, H. G., 1941, Selenium occurrence in certain soils in the United States, with a discussion of related topics, sixth report; U.S. Dept. Agriculture Tech. Bull. 783, 27 p.

Lakin, H. W., and Trites, A. R., Jr., 1958, The behavior of selenium in the zone of oxidation: Internat. Geol. Cong., 20th, Mexico 1956, Symposium de Explorácion Geoquimica, v. 1, p. 113-124.

Levine, V. E., 1925, The effects of selenium compounds upon growth and germination in plants: Am. Jour. Botany, v. 12, no. 2, p. 82-90.

Lewis, A. H., 1943, The teart pastures of Somerset, II. The relation between soil and teartness: Agr. Sci. Jour., v. 33, p. 52-57.

Lexow, S. G., Maneschi, E. P. P., and Sa, A. M., 1948, Preliminary note on the presence of uranium in living things in Argentina: Anales Assoc. Quimica Argentina, v. 36, p. 203-207.

Lipp, C. C., 1922, Alkali disease: Veterinary Alumni Quart. [Ohio State Univ.], v. 10 , p. 54-55.

Loew, Oskar, 1902, On the effect of uranium on plants: Tokyo Coll. Agr. Bull., v. 5, p. $173-175$.

Long, W. G., Sweet, D. V., and Tukey, H. B., 1956, The loss of nutrients by leaching of the foliage: Michigan State Univ. Agr. Expt. Sta. Quart. Bull. 38, p. 528-532.

Lotspeich, F. B., 1958, The movement of metallic elements in shallow colluvium: Internat. Geol. Cong., 20th, Mexico 1956, Proc. Symposium de Explorácion Geoquimica, v. 1, p. 125-142.

Lounamaa, J., 1956, Trace elements in plants growing wild on different rocks in Finland-A semi-quantitative spectrographic survey: Annales Bot. Soc. Vanamo, Helsinki, v. 29, no. 4, 196 p.

Madison, T. C., 1860, Sanitary report-Fort Randall, in Coolidge, R. H., Statistical report on the sickness and mortality in the Army of the United States, January 1855 to January 1860: U.S. Cong. 36th, 1st sess., Senate Ex. Doc., v. 52, p. 37-41.

Malyuga, D. P., 1958, Fxperiment in biogeochemical prospecting for Mo in Armenia: Geokhimiya 1958, no. 3, p. 248-266 (in Russian).

Marmo, Vladimir, 1955, Über die Anwendung von Ledum palustre in der biogeochemischen Prospektierung. [The use of Ledum palustre in biogeochemical prospecting]: Archivum Societatis Zoologicae Botanicae Fennicae "Vanamo," p. $170-173$.

Martin, A. L., 1936, Toxicity of selenium to plants and animals: Am. Jour. Botany, v. 23, no. 7, p. 471-483.

Mehlich, Adolf, and Drake, Mack, 1955, Soil chemistry and plant nutrition, in Bear, F. E., ed., Chemistry of the Soil: New York, Reinhold Pub. Corp., p. $286-327$. 
Meinzer, O. E., 1923, The occurrence of ground water in the United States, with a discussion of principles: U.S. Geol. Survey Water-Supply Paper 489, 321 p. 1927, Plants as indicators of ground water: U.S. Geol. Survey WaterSupply Paper 577, $95 \mathrm{p}$.

Miesch, A. T., and Connor, J. J., 1956, Distribution of elements, in Geologic investigations of radioactive deposits - Semiannual progress report, December 1, 1955, to May 31, 1956: U.S. Geol. Survey TEI-620, p. 128-146, issued by U.S. Atomic Energy Comm. Tech. Inf. Service, Oak Ridge, Tenn.

Mitchell, R. L., 1954, Trace elements in some constituent species of moorland grazing: British Grassland Soc. Jour., v. 9, no. 4, p. 301-311.

Moxon, A. L., and Olson, O. E., 1940, Selenium content of plants and soils: South Dakota Agr. Expt. Sta. 53d Ann. Rept., v. 15.

Moxon, A. L., Olson, O. E., and Searight, W. V., 1939, Selenium in rocks, soils, and plants: South Dakota Agr. Expt. Sta. Tech. Bull. 2, 94 p.

Moxon, A. L., Olson, O. E., Searight, W. V., and Sandals, K. M., 1938, The stratigraphic distribution of selenium in Cretaceous formations of South Dakota and the selenium content of some associated vegetation: Am. Jour. Botany, v. 25, no. 10 , p. 794-809.

Myers, A. T., and Hamilton, J. C., 1960, Rhenium in plant samples from the Colorado Plateau [abs.]: Geol. Soc. America Bull., v. 71, no. 12, pt. 2, p. 1934.

Nelson, E. M., Hurd-Karrer, A. M., and Robinson, W. O., 1933, Selenium as an insecticide: Science, v. 78, p. 124.

Newman, W. L., 1957, Distribution of elements, in Geologic investigations of radioactive deposits-Semiannual Progress report, December 1, 1956, to May 31, 1957: U.S. Geol. Survey TEI-690, p. 478-490, issued by U.S. Atomic Energy Comm. Tech. Inf. Service, Oak Ridge, Tenn.

Nilan, R. A., 1956, Factors governing plant radiosensitivity, in A conference on radioisotopes in agriculture: U.S. Atomic Energy Comm. TID-7512, p. 151-162.

Olson, O. E., 1939, The adsorption of selenium by certain inorganic colloids: South Dakota Acad. Sci. Proc. 19, p. 22-24.

Olson, O. E., and Jensen, C. W., 1940, The adsorption of selenate and selenite selenium by colloidal ferric hydroxide: South Dakota Acad. Sci. Proc., v. 20, p. 115-121.

Olson, O. E., Jornlin, D. F., and Moxon, A. L., 1942, Field studies on methods for determining availability of selenium to plants: Soil Sci., v. 53, no. 5, p. 365-368.

Olson, O. E., Whitehead, E. I., and Moxon, A. L., 1942, Occurrence of soluble selenium in soils and its availability to plants [South Dakota]: Soil Sci., v. 54, no. 1, p. 47-53.

Ostle, D., 1954, Geochemical prospecting for uranium: (England) Mining Mag., v. 91, p. 201-208.

Page, L. R., Stocking, H. E., and Smith, H. B., compilers, 1956, Contributions to the geology of uranium and thorium by the United States Geological Survey and Atomic Energy Commission for the United Nations International Conference on Peaceful Uses of Atomic Energy, Geneva, Switzerland, 1955: U.S. Geol. Survey Prof. Paper 300, 739 p.

Peters, A. T., 1904, A fungus disease in corn: Nebraska Agr. Expt. Sta. 17th Ann. Rept., p. 13-22. 
Petri, Lionello, 1929, Comportamento dell' olivo sotto l'influenza delle radiazioni dell' uranio e della ionizzazinoe dell'aria [Effects of uranium radiation and ionization of the air on the olive]: Atti Reale Accad. Naz. Lincei. Classe Sci. Fis., Mat. e. Nat., ser. 9, p. 188-189.

- 1930, Pathologische Wirkungen der Uranstrahlen auf Olea europea [Pathological effects of uranium radiation on Oleo europea]: Phytopathol. Z., v. 1, p. $45-48$.

Phoenix, D. A., 1959, Occurrence and chemical character of ground water in the Morrison formation, in Geochemistry and mineralogy of Colorado Plateau uranium ores: U.S. Geol. Survey Prof. Paper 320, p. 55-64.

Ramirez, E. C., 1914, Vanadium and its action on plant growth: Anales Soc. Quimica Argentina, v. 2, no. 6, p. 145-146.

Rankama, Kalervo, and Sahama, T. G., 1950, Geochemistry: Chicago Univ. Press, $911 \mathrm{p}$.

Roach, C. H., and Thompson, M. E., 1959, Sedimentary structures and localization and oxidation of ore at the Peanut mine, Montrose County, Colorado, in Geochemistry and mineralogy of Colorado Plateau uranium ores: U.S. Geol. Survey Prof. Paper 320, p. 197-202.

Robinson, T. W., 1958, Phreatophytes: U.S. Geol. Survey Water-Supply Paper $1423,84 \mathrm{p}$.

Robinson, W. O., 1933, Determination of selenium in wheat and soils: Assoc. Official. Agr. Chem. Jour., v. 16, p. 423-424.

Robinson, W. O., and Dever, R. F., 1956, The composition of soils, peats, and plants associated with cattle malnutrition: Soil Sci., v. 82, no. 4, p. 275-285.

Robinson, W. O., and Edgington, Glen, 1947, Toxic aspect of molybdenum in vegetation: Soil Sci., v. 66, p. 197-198.

Robinson, W. O., Steinkoenig, L. A., and Miller, C. F., 1917, The relation of some of the rarer elements in plants and soils: U.S. Dept. Agriculture Bull. 600, $25 \mathrm{p}$.

Rothstein, Asa, 1953, Studies in cell metabolism, in Voegtlin, Carl, and Hodge, H. C., Pharmacology and toxicology of uranium compounds, Pt. III, Chronic studies: New York, McGraw-Hill Book Co., p. 1992-2000.

Rothstein, Asa, and Meier, R. C., 1953, Chemical nature of uranium-complexing groups of the cell surface, in Voegtlin, Carl, and Hodge, H. C., Pharmacology and toxicology of uranium compounds, Pt. III, Chronic studies: New York, McGraw-Hill Book Co., p. 2014-2034.

Rydberg, P. A., 1917, Flora of the Rocky Mountains and adjacent plains: New York, pub., by author, $1110 \mathrm{p}$.

Saukoff, A. A., 1956, Radiohydrogeological method in prospecting for uranium deposits, in Geology of uranium and thorium: New York, United Nations Internat. Conf. Peaceful Uses Atomic Energy, August 1955, v. 6, p. 756-759.

Scharrer, K., and Schropp, W., 1935, Über die Wirkung des V auf Kulturpflanzen [The action of V upon cultivated plants]: Zeitschr. Pflanzenernähr., Düng. Bodenkunde, v. 37, p. 196-202.

Sergeev, E. A., 1941, The geochemical method of prospecting for ore deposits: Materials of Soviet Union, Geol. Inst. Geophysics, fasc. 9-10, p. 3-55. Translated by V. P. Sokaloff, in Selected Russian papers on geochemical prospecting for ore: U.S. Geol. Survey, February 1950, p. 15-87.

Shibuya, Kisaburo, and Saeki, H., 1934, Effect of vanadium on growth of plants, II: Jour. Soc. Tropical Agriculture, Japan, v. 6, p. 721.

Shields, L. M., and Wells, P. V., 1962, Effects of nuclear testing on desert vegetation: Science, v. 135 , no. 3497 , p. 38-40. 
Shoemaker, E. M., Miesch, A. T., Newman, W. L., and Riley, L. B., 1959, Elemental composition of the sandstone-type deposits, in Geochemistry and mineralogy of the Colorado Plateau uranium ores: U.S. Geol. Survey Prof. Paper 320, p. 25-54.

Shoemaker, E. M., Newman, W. L., and Miesch, A. T., 1956, Sources of the elements in the sandstone-type uranium deposits of the Colorado Plateau: U.S. Geol. Survey TEI-629, 54 p., issued by U.S. Atomic Energy Comm. Tech. Inf. Service, Oak Ridge, Tenn.

Shrift, Alex, 1954, Sulfur-selenium antagonism, I. Antimetabolite action of selenate on the growth of Chlorella vulgaris: Am. Jour. Botany, v. 41, p. 223-230.

Skirvin, O. W., 1922, Experimental study of the invasion of oil into a water-wet sand: Econ. Geology, v. 17, no. 6, p. 461-469.

Sparrow, A. H., and Pond, Virginia, 1956, Some cytogenetic and morphogenetic effects of ionizing radiation on plants, in $\mathrm{A}$ conference on radioactive isotopes in agriculture: U.S. Atomic Energy Comm. TID-7512, p. 125-139.

Sparrow, A. H., and Singleton, W. R., 1953, The use of radiocobalt as a source of gamma rays and some effects of chronic irradiation on growing plants: Am. Naturalist, v. 87, p. 29-48.

Stanford, G. W., Olson, O. E., 1939, The effect of low concentrations of selenium upon the growth of grain: South Dakota Acad. Sci. Proc., v. 19, p. 25-31.

Stokes, W. L., 1952a, Uranium-vanadium deposits of the Thompsons area, Grand County, Utah, with emphasis on the origin of carnotite ores. Utah Geol. and Mineralog, Survey Bull. 46, $51 \mathrm{p}$.

-1952b, Lower Cretaceous in Colorado Plateau: Am. Assoc. Petroleum Geologists Bull., v. 36, no. 9, p. 1766-1776.

Stoklasa, Julius, 1922a, Influence du sélénium et du radium sur la germination des grains [The influence of selenium and of radium in the germination of seeds]: Acad. Sci. [Paris] Comptes rendus, v. 174, no. 16, p. 1075-1077.

-1922b, Influence du sélénium sur l'évolation végétale, en presence ou en l'absence de radioactivité [Influence of selenium on piant development, in presence or absence of radioactivity]: Acad. Sci. [Paris] Comptes rendus, v. 174 , no. 19 , p. 1256-1258.

Stoklasa, Julius, and Penkava, Joseph, 1928, Biologie des radiums et uraniums [Biology of radium and uranium]: Zeitschr. Biochemistry, v. 194, p. 15-76.

Stout, P. R., Meagher, W. R., Pearson, G. A., and Johnson, C. M., 1951, Molybdenum nutrition of cro $\rho$ plants, I. The influence of phosphate and sulfate on the absorption of molybdenum from soils and solution cultures: Plant and soil, v. 3, p. 51-87.

Suzuki, S., 1903, On the action of vanadium compounds on plants: Tokyo Bull. Agr., v. 5, p. 513-515.

Taboury, M. F., and Manceau, Joseph, 1946, Distribution of selenium in the different parts of white mustard and of rape cultivated in soil containing selenium and harvested after maturity: Acad. Sci. [Paris] Comptes rendus, v. 223, p. 337-339.

Ter Meulen, H., 1931, Sur la repartition der molybdène dans la nature [On the distribution of molybdenum in nature]: Rec. travaux chim., v. 50, p. 491-504.

Ter Meulen, H., and Ravenswaay, H. F., 1935, The molybdenum content of leaves: Royal Acad. Sci. Amsterdam Proc., v. 38, p. 7-10.

The Washington Post Co., Sunday, Oct. 13, 1946, Hiroshima: Washington, D.C. Trelease, S. F., 1942, Identification of selenium indicator species of Astragalus by germination tests: Science, v. 95, no. 2478, p. 656-657. 
Trelease, S. F., and Beath, O. A., 1949, Selenium; its geological occurrence and its biological effects in relation to botany, chemistry, agriculture, nutrition, and medicine: published by authors, Box 42, Schermerhorn Hall, Columbia Univ., New York, N.Y.; 292 p.

Trelease, S. F., and Trelease, H. M., 1938a, Selenium as a stimulating and possibly essential element for certain plants: Science, v. 87 , no. 2247 , p. 70-71. -1938 b, Selenium as a stimulating and possibly essential element for indicator plants: Am. Jour. Botany, v. 25, p. 372-380.

1939, Physiological differentiation in Astragalus with reference to selenium: Am. Jour. Botany, v. 26, p. 530-535.

Tsivoglou, E. C., Shearer, S. D., Shaw, R. M., Jr., Jones, J. D., Anderson, J. B., Sponagle, C. E., and Clark, D. A., 1959, Survey of interstate pollution of the Animas River (Colorado-New Mexico) : Cincinnati, Ohio, U.S. Dept. Health, Education, and Welfare., $53 \mathrm{p}$.

U.S. Atomic Energy Commission, 1957, Standards for protection against radiation: Federal Register, v. 22, pt. 20, no. 19 (Jan. 29, 1957).

Verducci, Paola, 1945, Comparative effect of radioactivity of uranium compounds on germination and development of seeds: Soc. Italiana Biol. Sper. Bull., v. 20 , p. $333-334$.

Vinogradova, Kh. G., and Drobkov, A. A., 1949, On the possible relation between molybdenum deficiency and the so-called clover fatigue: Akad. nauk. SSSR Doklady 68, p. 357-360.

Voelcker, J. A., 1925, Pot-culture experiments-1923: Harpenden, England, Rothamsted Expt. Sta. Rept. 1923-1924, p. 89-97.

Walsh, T., Fleming, G. A., O'Connor, R., and Sweeney, A., 1951, Selenium toxicity associated with an Irish soil series: Nature, v. 168, p. 881.

Ward, F. N., and Marranzino, A. P., 1957, Field determination of uranium in natural waters: U.S. Geol. Survey Bull. 1036-J, p. 181-192.

Warington, Katherine, 1937, The effect of molybdenum on plants with special reference to the Solanaceae: Ann. Appl. Biology, v. 24, p. 473-493.

- 1951, Interrelationships of manganese, molybdenum, and vanadium in the nutrition of soybean, flax, and oats: Ann. Appl. Biology, v. 38, no. 3, p. 624-641.

- 1956, Interaction between iron and molybdenum or vanadium in nutrient solutions with and without a growing plant: Ann. Appl. Biology, v. 44, no. 4, p. 535-546.

Warren, H. V., Delavault, R. E., and Irish, R. I., 1952, Preliminary studies on biogeochemistry of iron and manganese: Econ. Geology, v. 47, no. 2, p. 131145.

Warren, H. V., Delavault, R. E., and Routley, D. C., 1953, Preliminary studies of biogeochemisty of molybdenum: Royal Soc. Canada Trans., $3 \mathrm{~d}$ ser., sec. 4, v. 47, p. 71-75.

Waters, A. C., and Granger, H. C., 1953, Volcanic debris in uraniferous sandstones, and its possbile bearing on the origin and precipitation of uranium: U.S. Geol, Survey Circ. 224, 26 p.

Weeks, A. D., 1953, Mineralogical study of some Jurassic and Cretaceous claystones and siltstones from western Colorado and eastern Utah: U.S. Geol. Survey TEI-285, $22 \mathrm{p}$.

1956, Mineralogy of uranium deposits, Geological investigations of radioactive deposits-Semiannual progress report, December 1, 1955, to May 31, 1956: U.S. Geol. Survey TEI-620, p. 123-127, issued by U.S. Atomic Energy Comm. Tech. Inf. Service, Oak Ridge, Tenn. 
Weeks, A. D., and Thompson, M. E., 1954, Identification and occurrence of uranium and vanadium minerals from the Colorado Plateaus: U.S. Geol. Survey Bull. 1009-B, p. 13-62.

Weir, D. B., 1952, Geologic guides to prospecting for carnotite deposits on Colorado Plateau: U.S. Geol. Survey Bull. 988-B, p. 15-27.

Westerfeld, W. W., and Richert, D. A., 1953, Distribution of the xanthine oxidase factor (molybdenum) in foods: Jour. Nutrition, v. 51, p. 85-95.

Williams, K. T., and Byers, H. G., 1934, Occurrence of selenium in pyrites: Indus. Eng. Chem., Anal. ed. 6, p. 296-297.

-1936, Selenium compounds in soils: Indus. Eng. Chem., v 28, p. 912-914.

Williams, K. T., Lakin, H. W., and Byers, H. G., 1940, Selenium occurrence in certain soils in the United States, with a discussion of related topics, fourth report: U.S. Dept. Agriculture Tech. Bull. 702, 59 p.

1941, Selenium occurrence in certain soils in the United States, with a discussion of related topics, fifth report: U.S. Dept. Agriculture Tech. Bull. $758,69 \mathrm{p}$.

Witz, Georges, and Osmond, Floris, 1886, Essais sur l'application des propriétés de l'oxycellulose au dosage du vanadium: Soc. Chim. Bull., ser. 2, v. 45, p 309-315. 


\section{INDEX}

[Italic page numbers indicate major references]

A

Abstract

Acknowledgments

Alfalfa, molybdenum content of -

Allium, effectiveness as an indicator

Allium acuminatum, mapping of.

Allium sp , effects of selenium on

Allor 12 mine, selenium in

Amanita, effects of vanadium on

Anthriscus silvestris, molybdenum content of.-

Aplopappus, phreatophytic character of .....

Apocynaceae

Atriplex, molybdenum content of phreatophytic character of.

Atriplex canescens, at the Nevada Test Site. confertifolia, collection.

rhenium content of

Aster, tolerance of radiation

Aster venustus, mapping of poor selenium indicator

Asterae, tolerance of miner

Astragalus

effects of molybdenum on

effects of selenium on.

molybdenum content of.

potassium and radium in

root growth of

selenium accumulation by

selenium accumulators and lators

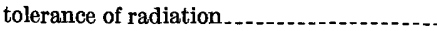

tolerance of uraniferous ground.

Astragalus aurens lagurus, molybdenum content of

confertiflorus, mapping of

effectiveness as an indic

presence of

selenium accumulation by

vanadium content of

lentiginosus, at the Nevada Test Site.

missouriensis, mapping of

poor selenium indicator

pattersoni.

distribution of

effectiveness as an indicator

effects of molybdenum on..........

effects of selenium on

indicator plant.

in Pittsburg Park

mapping of

rhenium content of

selenium accumulation by

vansdium content of

preussi

copper content of

distribution of
Page

4

78

101

98

84

27

72

78

11

65

79

11

61

98

94

62

96

98

64

78

82

79

70

20

62

78

96

100

101

89
Astragalus-Continued

preussi-Continued

effectiveness as an indicator........ 100

effects of selenium on................ 85

effects of vanadium on

indicator plant. 106

mapping of ....... 96

nickel content of

rhenium content of

selenium accumulation by.......... 89

vanadium content of . .

racemosus, effects of selenium on ........ 82

selenium content of

thompsonae, mapping of _....... 96

Azotobacter, activity of ............ 71

$\mathbf{B}$

Blackstone 6 mine, selenium in sulfides. .....

Botanical prospecting . evaluation of methods of

plant-analysis method. 106

Brushy Basin Shale Member of the Morrison Formation

mudstones in.-... 33

Burro Canyon Formation.......... 14

\section{$\mathbf{C}$}

Cactus Rat claims............. 12

deposit, location of . 14

group, gypsiferous ores in.......... 96

mine, presence of uranium salts....... $\quad 36$

spring, selenium content._._...... 40

Cadigan, R. A., quoted........... 13

Calcium analyses..._.

Calluna, vanadium content of .

Canyon Lands physiographic subdivision.... $\quad 6$

Carduaceae, sensitivity to radioactivity .... 62

Carnotite.......... 15

leaching of . . . 21

Carnotite deposits, Colorado Plateau........ 38

Carnotite ore, selenium in.............. 26

Carriers of trace metals in plants

Castilleja, radiosensitivity of ......... 64

Cedar Mountain Formation

Chemical preference of plants.

Chenopodiaceae, molybdenum and selenium in

resistance to radioactivity _......... 62

Chenopods, tolerance of radiation _..... 62

Chinle Formation

Chlorella vulgaris, selenium content of

Chlorosis due to selenium

Chrysanthemum, tolerance of radiation..... 62 
Page

Chrysothamnus, molybdenum content of.....phreatophytic character of uranium transport in. lation and indication by

Clausthalite, at Rifle, Colo at the Virgin mine Ceome serrulata, effects of selenium on selenium content of

Cneoridium dumosum, molybdenum content of.

Coffinite. -

Coleogyne ramosissima, at the Nevada Test Site

Colorado Plateau

selenium in samples.

selenium in sulfides.

Compositae, molybdenum and selenium in

Composition of vegetation, effects of mineral excesses.

Concentration of elements.

Concentration of vanadium

Conclusions

Copper analyses

Corvusite

Cowania stansburiana, collection of phreatophytic character ofvanadium content of ruciferae, molybdenum and selenium in resistance to radioactivity

\section{$\mathrm{D}$}

Dakota Sandstone

Decay products of uranium, content in plants.-

Descurainia obtusa, effects of selenium on. .-.-

Determination method, uranium content of plants

vanadium content of plants.

Drilling in the Yellow Cat area

Dune sand

Dwarfing due to selenium ....................

\section{E}

Edible fruits and vegetables, radioactive decay products in

Effects of uranium, as a nutrient. as a source of radioactivity.

Effects of vanadium on plants

Effect on plants, of uranium. of uranium daughter products.

Elymus, phreatophytic character of

Elymus salina, selenium accumulation and indication by

Element excesses, effect on plant distribution of.

Elements, concentration of

Entrada Sandstone.

Ephedra, molybdenum content of selenium poisoning from uranium transport in.

Ephedra gallica, selenium accumulation and indication by

viridis, lead content of

rhenium content of.

Eriogonum inflatum, effectiveness as an indicator.

$$
\text { mapping of }
$$

sp., rhenium content of ...................

Eriogonum, at the Nevada Test Site..........

molybdenum content of. ..................

tolerance of radiation. .......................

Erodium cicutarium, at the Nevada Test Site. .

Fauna, present-day

Favorable effects of uranium.

Ferroselite, at the Virgin mine...............

Flattop area, areas of favorable ground on....

Flattop group, location of

Foods, tolerance limits of radioactive elements

Eraxinus, molybdenum content of phreatophytic character of

Frarinus anomala, lead content of

\section{G}

Galena, at Rifle, Colo.

Gamma radiation, effects on plants........... Garrels, R. M., and Christ, C. L., quoted.--Gentiana, molybdenum content of...........-.

Geochemical associations of elements.........

Geochemical targets for prospecting............

Geologic preference of plants..................-.

Gladiolas, effects of gamma radiation.......... resistance to radioactivity . .................

Grayia spinosa, at the Nevada Test Site...... radiosensitivity of.

Green River district, selenium in .............

Grindelia, effects of molybdenum on.........molybdenum content of.................... rooted in carnotite. tolerance of uraniferous ground......... vanadium content of.........................

Grindelia aphanactis, effects of selenium on.-. fastigiata, rhenium content of ..............

Growth changes, plants rooted in carnotite ... Growth effects, of molybdenum on plants....

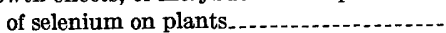
of uranium . ............................... of uranium daughter products. of vanadium on plants. 58

Growth habits of vegetation, effect of mineral

excesses..............................

Gyms, effects of gamma radiation...-

Gypsiferous ores plants from

\section{H}

Hedysarum boreale, phreatophytic character of Henry Mountains, selenium in samples....... Hermosa Formation, Paradox Member......Hiroshima, radiation effects on plants at...... Hydrated uranyl carbonates................... 94 Hymenoclea, at the Nevada Test Site ......... 
Ilsemannite.

Indication of selenium by plants

Indicator-plant method of botanical prospecting

Indicator plants, mapping of.

"Inner space" of plant tissue.

Ion absorption, in plants.

Ion accumulation, factors affecting

Ion transport, in plants.

\section{J}

Joshua trees, at the Nevada Test site.

Juniper, anomalous uranium content of.-.-.-Juniper, traverse sampling of -

Juniperus, molybdenum content of phreatophytic character of.

Juniperus monosperma lead content of

\section{L}

Larrea divaricata, concentrations of uranium in. La Sal Mountains.

Lead analyses.

Ledum palustre, molybdenum content of -..-Legumes, molybdenum content of.

Leguminosae, molybdenum and selenium in

Lepidium, molybdenum content of tolerance of radiation

Little Eva mine, discovery of. indicator plants at. selenium in sulfides

Little Pittsburg group, location of

\section{$\mathbf{M}$}

McCoy bench, uranium in soil samples

MeCoy claims

McCoy group, areas of favorable ground y group, areas of favorable ground in ... mapping of plants in rhenium analyses of plants from schroeckingerite deposit.

sampling of plants in.

schoeckingerite deposit

Memphis Hill, deposits of -

gypsiferous ores on.

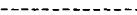

mapping of plants

Mentzelia albicaulis, association with mineralized ground.

at the Nevada Test Site

tolerance of radiation.

Metahewettite.

Metal chelate compounds.

Metal content, of plants.-................... of the mudstones.

Metallic elements, source of . . . .

Mining

Mirabilis, association with mineralized ground. tolerance of radiation

Molybdenum accumulation by plants.

Molybdenum in plants.
Page

Montmorillonite, ion replacement in

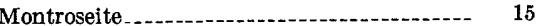

Morrison Formation.

Brushy Basin Shale Member.-...-...-.- 12

Salt Wash Sandstone Member......... 2,3,12,16

\section{$\mathrm{N}$}

Nagasaki, radiation effects on plants at-.-..... Nevada Test Site, radiation effects on plants at...... 61

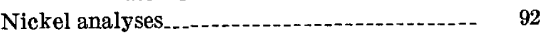

Nicotiana plants, effects of gamma radiation.- $\quad 60$

Oonopsis, selenium accumulation by-.-.... $\quad 87$

Oonopsis condensata, molybdenum content of. $\quad 78$

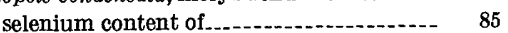

Ore deposits, types............- 15

Ore minerals. . . . .

Oryzopsis, molybdenum content of ......... $\quad 79$ tolerance of radiation................- 62

Oryzopsis hymenoides, at the Nevada Test Site.

mapping of

poor selenium indicator................. 98

"Outer space" of plant tissue..............-. 42

P

Paradox Basin ................. 12

Paradox Member of the Hermosa Formation. 12

Paradox Valley, rhenium analyses of plants from

Parko section, selenium in

Parko 23 claims, indicator plants on .....-.- 104

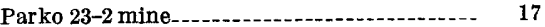

Pascoite, native selenium with _........... 26

Peanut mine, native selenium in........... $\quad 26$

Perched water tables. -..--.-.-...- 11

Phosphoria Formation, source of vanadium.-- $\quad 41$

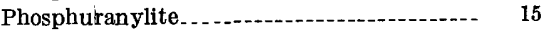

Phosphorus analyses........................... 93

Phreatophytes...-..-..- 11, 68

Phreatophytes in prospecting.-.......... 41

Pierre Shale, selenium in sulfides.-.-.--.--. $\quad 27$

Pinaceae, sensitivity to radioactivity. .......- $\quad 62$

Pitchblende.

Pittsburg Park

Astragalus pattersoni in.................. 104

gypsiferous ores in.................. 96

indicator plants in.................... 101

mapping of plants in .

Plant-analysis method of botanical prospecting -

Plant collection for uranium analyses.....-.-- $\quad 98$

Plant distribution, effect of element excesses on

Plant tolerance of uranium . . 
Plants, chemical preference of effects of vanadium on

field mapping of grow th effects of selenium on. geologic preference of. molybdenum in sample collection of selenium in tolerance of molybdenum by tolerance of selenium by tolerant of mineralized ground

Plants rooted in schroeckingerite, uranium content of

Poison Basin area, selenium in ores.

Populus, phreatophytic character of

Portulac $a$, tolerance of radiation.

Portulacaceae, resistance to radioactivity

Potassium content of Astragalus...............

Previous work

on effects of uranium on plants.

on indicator plants

on molybdenum in plants.

on selenium in plants

on uranium accumulation by plants

on vanadium accumulation by plants....-

Pyrite, at the Virgin mine

\section{Q}

Quercus, molybdenum content of

Quercus wislizeni, molybdenum content of.---

\section{R}

Radiation effects on plants at Nagasaki and Hiroshima

at the Nevada Test Site

Radium content of Astragalus.

Radium in edible fruits and vegetables.......

Rauvite

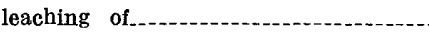

Rhenium analyses.

Rifle, Colo., vanadiferous ore at.

Roscoelite

Russianthistle, association with disturbed ground

S

Sagers Wash syncline.

Salsola, at the Nevada Test Site.............. Salt Wash Sandstone Member of the Morrison Formation

metal content of $2,3,12,16$

mudstones in

sandstone in.

Salt Valley anticline

San Rafael Swell

Sarcobatus, phreatophytic character of

Scabiosa, molybdenum content of

Schinopsis lorentzii, concentrations of uranium in

School Section claims, location of

Schroeckingerite

Schroeckingerite deposit, McCoy group -..rhenium analyses of plants from
11

Scrophulariaceae, radiosensitivity of sensitivity to radioactivity ................

Sedums, effects of gamma radiation........-.-

Selenium accumulator plants............-..- 86

Selenium-uranium analyses..........-......... 27

Selenium indicator plants . grouping of................. 2

Selenium in plants . .

Selenium in sulfides.

Selenium, relation to ore minerals .....-..-. $\quad 27$

Senecioneae, tolerance of mineralized ground.. $\quad 64$

Shadscale, traverse sampling of.-.-..--.--_ $\quad 67$

Shadscale saltbush, anomalous uranium content

Shallow oxidized ore, effect on vegetation -..-- $\quad 42$

Shoemaker, E. M. and others, quoted ....... 26, 27

Snapdragons, effects of gamma radiation....- $\quad 60$

Soil-analysis prospecting

Solanaceae, effects of molybdenum on......- $\quad 77$ sensitivity to radioactivity

Solidago petradoria, selenium accumulation and indication by

Sorghum plants, effects of vanadium on $\ldots . . .-\quad 73$

Sphaeralcea, at the Nevada Test Site $\ldots . . .-62$ tolerance of radiation.................... 62

Sphaeralcea parviflora, selenium accumulation and indication by

Stanleya, rooted in carnotite...........-. 61 selenium accumulation by _............... $\quad 87$

Stanleya pinnata, effectiveness as an indicator. $\quad 100$ effects of selenium on............-...-..- 84 mapping of selenium content of

Steigerite_..-_-.-_- 15

Stipa, tolerance of radiation...............-.- 62

Strontium 90 and 89 in edible fruits and vegetables.

Studies of selenium poisoning Suite of elements, most strongly enriched Summerville Formation_...................- 14

\section{$\mathbf{T}$}

Table Mountain, selenium in samples...-.... 25 Tamarix

Teart, caused by excess of molybdenum...-. $\quad 77$ The Washington Post, quoted.............-. 61

Thompson distr1st, climate_......... 37 minerals present........-..-.-.- 36 selenium in..--..-..- 25 selenium-uranium analyses..............- 28

Tolerance limits of radioactive elements in foods.

Tolerance of molybdenum in plants. ....-... $\quad 76$

Tolerance of selenium by plants............ 81

Tolerance of uranium by plants........- $\quad 61$

Tolerance of vanadium by plants............ $\quad 71$

Townsendia incana, selenium accumulation and indication by

Tradescentia paludosa, sensitivity to radioactivity -

Transpiration rate, relation to ion exchange-.-

Trelease, S. G. and Beath, O. A., quoted.-.--

Trifolium, molybdenum content of...-..-.-- 
Tyuyamunite

leaching of

native selenium with

\section{U}

Uncompahgre uplift

Unfavorable effects of uranium

Uranium accumulation by plants

Uranium analyses, collection of plants for

Uranium content of plants, determination method

Uranium, previous work on effects on plants of

Uranium tolerance of plants

Uravan mineral belt

selenium in

selenium-uranium analyses

uranium and vanadium in

Vanadium, absorption of accumulation by plants

"Vanadium bush" (Cowania stansburiana) Vanadium content of plants, determination method

Vanadium hydromica.

Vanadium toxicity, physiological symptoms of.

Variations of metal content of sandstones

Vegetation, present-day

Verbesina, vanadium content of

Verbesina enceliodes exauriculata, effects of selenium on

Virgin mine, minerals at

6

Weathering of ore minerals, present-day .......

Windy Point claims, location of............ 14

(11,68

Xylorrhiza, selenium accumulation by _..... 87

Xylorrhiza parryi, molybdenum content of.-- 78

\section{$\mathbf{Y}$}

Yellow Cat Campsite. . . .

Yellow Cat dome._._._. 12

Yellow Cat Mesa......... 3

areas of favorable ground on ........ 106

indicator plants on...................... 104

uranium in soil samples. . ........... 41

Yucca, molybdenum content of $\quad 79$

tolerance of radiation. .................... 62

Z

Zygadenus gramineus, selenium accumulation and indication by.............. 88 
The U.S. Geological Survey Library has cataloged this publication as follows:

\section{Cannon, Helen E.} (Leighton) 1911-

Geochemistry of rocks and related soils and vegetation in the Yellow Cat area, Grand County, Utah. Washington, U.S. Govt. Print. Off., 1964.

vi, 124 p. illus., maps ( 3 fold., 1 col., in pocket) diagrs., tables. $24 \mathrm{~cm}$. (U.S. Geological Survey. Bulletin 1176)

Prepared on behalf of the U.S. Atomic Energy Commission.

Bibliography : p. 111-122.

(Continued on next card)

\section{Cannon, Helen E. $\quad$ (Leighton) 1911-}

Geochemistry of rocks and related soils and vegetation in Yellow Cat area, Grand County, Utah. 1964. (Card 2)

1. Geochemistry-Utah-Grand Co. 2. Prospecting. 3. Ore-deposits-Utah-Grand Co. I. Title. (Series) 
